João Maria Corrêa Filho

\title{
Eficácia da ondansetrona no tratamento de dependentes de álcool
}

Tese apresentada à Faculdade de Medicina da Universidade de São Paulo para obtenção do título de Doutor em Ciências

Programa de Psiquiatria Orientador: Prof. Dr. Danilo Antonio Baltieri

São Paulo 2013 
Dados Internacionais de Catalogação na Publicação (CIP)

Preparada pela Biblioteca da

Faculdade de Medicina da Universidade de São Paulo

Creprodução autorizada pelo autor

\section{Corrêa Filho, João Maria}

Eficácia da ondansetrona no tratamento de dependentes de álcool / João Maria

Corrêa Filho. -- São Paulo, 2013.

Tese(doutorado)--Faculdade de Medicina da Universidade de São Paulo.

Programa de Psiquiatria.

Orientador: Danilo Antonio Baltieri.

Descritores: 1.Alcoolismo 2.Ondansetrona 3.Desistência do tratamento 4.Análise por conglomerados 5.Psicotrópicos 6.Ensaio clínico 7.Transtornos relacionados ao uso de substâncias 8.Alcoólicos anônimos

USP/FM/DBD-163/13 
Dedicatória

Aos meus pais, João Maria Corrêa e Rosina Fogliatto Corrêa, pelo exemplo de vida e incentivo ao estudo.

A minha esposa, Gabriela, pelo amor e compreensão.

Aos meus filhos, Lara, João Pedro e Valentina, pelos momentos únicos. 
Agradecimentos

Ao meu orientador, Prof. Dr. Danilo Antonio Baltieri, cujo estímulo acadêmico tem sido fundamental a minha formação, sendo exemplo da capacidade de aliar compreensão e rigor a ser seguido durante a minha vida.

Ao Prof. Dr. Arthur Guerra de Andrade, cuja capacidade de estimular as pessoas a sua volta e de visão estratégica é um exemplo que perseguirei.

Ao Erley Sassi e Fernanda Celeste Sassi, amigos e profissionais que contribuíram para minha formação psiquiátrica.

Ao grupo Interdisciplinar de Estudos de Álcool e Drogas do Instituto de Psiquiatria do Hospital das Clinicas da Faculdade de Medicina da Universidade de São Paulo, em especial a Celi, Ednei e Roberta, por entenderem a importância deste tema e pelo constante apoio para realização deste trabalho.

À Fundação de Amparo à Pesquisa do Estado de São Paulo (FAPESP), que financiou esta pesquisa (Projeto $n^{\circ}$ 07/54009-8).

A Divisão de Farmácia do Instituto de Psiquiatria do Hospital das Clínicas da Faculdade de Medicina da Universidade de São Paulo, que contribuiu diretamente para a realização desta pesquisa.

Aos pacientes que são um estimulo para o aperfeiçoamento continuo. 
"A resposta certa não importa nada. O essencial é que as perguntas estejam certas."

Mário Quintana 
Esta tese está de acordo com as seguintes normas, em vigor no momento desta publicação:

Referências: adaptado de International Committee of Medical Journals Editors (Vancouver).

Universidade de São Paulo. Faculdade de Medicina. Divisão de Biblioteca e Documentação. Guia de apresentação de dissertações, teses e monografias. Elaborado por Anneliese Carneiro da Cunha, Maria Julia de A. L. Freddi, Maria F. Crestana, Marinalva de Souza Aragão, Suely Campos Cardoso, Valéria Vilhena. 3a ed. São Paulo: Divisão de Biblioteca e Documentação; 2011.

Abreviaturas dos títulos dos periódicos de acordo com List of Journals Indexed in Index Medicus. 


\section{Sumário}

Lista de Tabelas

Lista de Figuras

Resumo

Summary

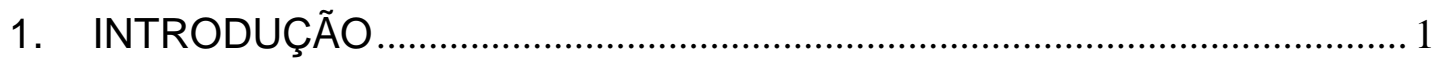

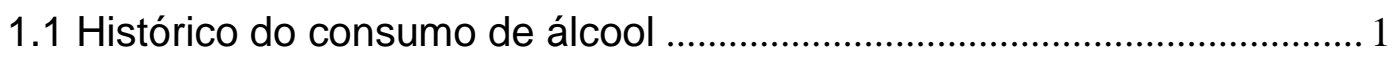

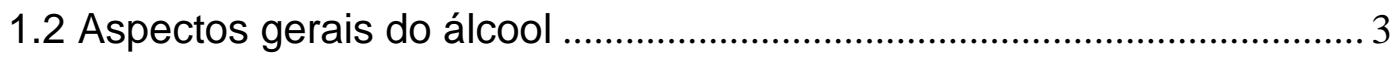

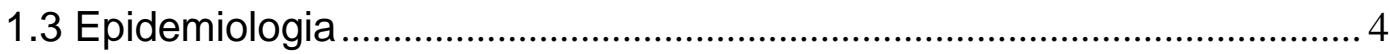

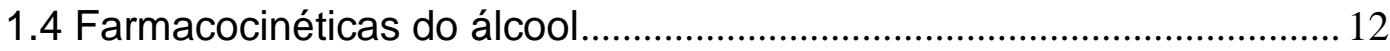

1.4.1 Efeito do álcool no sistema nervoso central .................................. 13

1.4.2 Anatomia da via da recompensa .................................................. 13

1.4.3 Neurobiologia do álcool .................................................................. 17

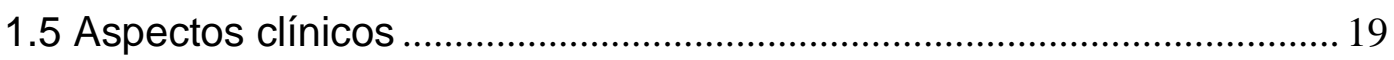

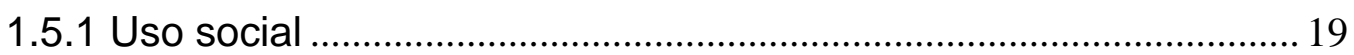

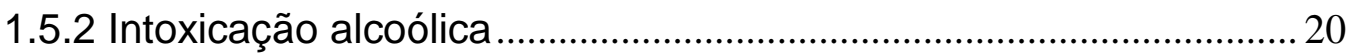

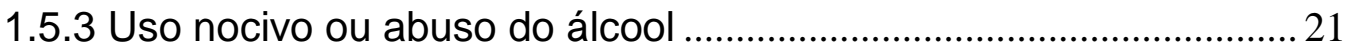

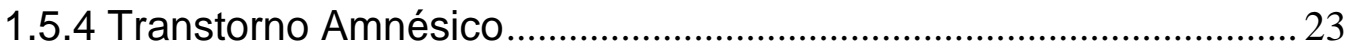

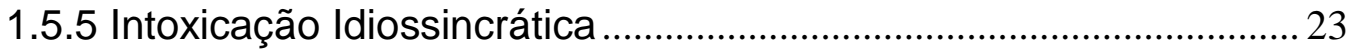

1.5.6 Síndrome de Dependência do Álcool................................................ 23

1.5.7 Síndrome de Abstinência do Álcool ................................................. 26

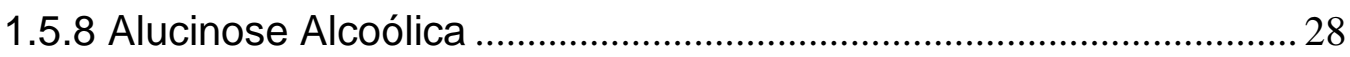

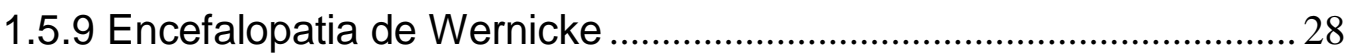

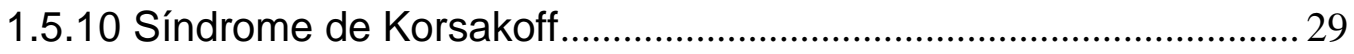

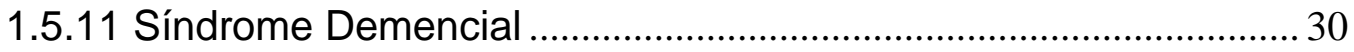

1.5.12 Tipologia para alcoolistas .............................................................. 31

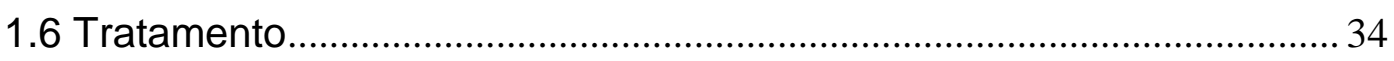

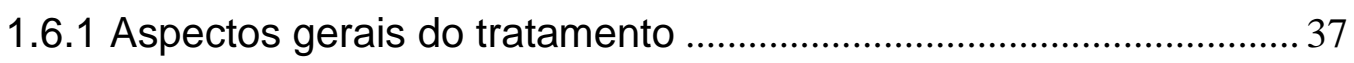

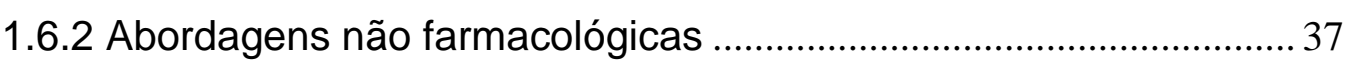

1.6.2.1 Terapia cognitivo-comportamental......................................... 37

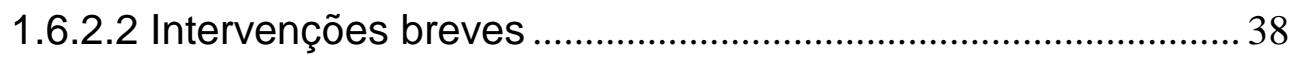

1.6.2.3 Treinamento de habilidades sociais ....................................... 39

1.6.2.4 Abordagem do fortalecimento comunitário ...............................39

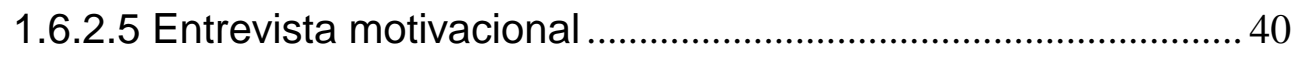

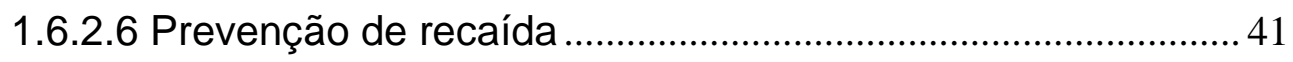

1.6.2.7 Contrato terapêutico ............................................................... 42 
1.6.2.8 Alcoólicos Anônimos 42

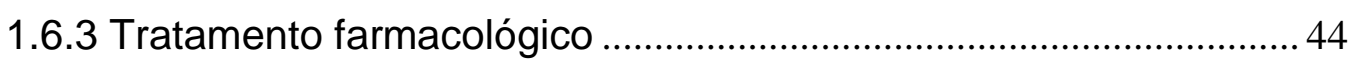

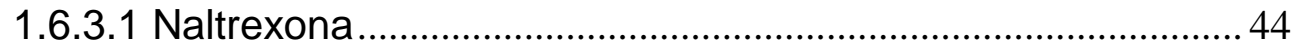

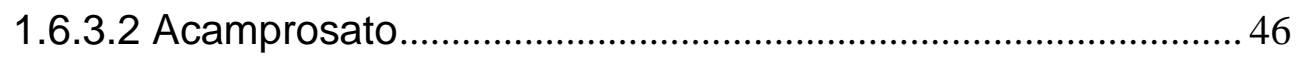

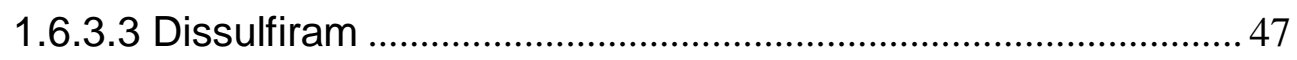

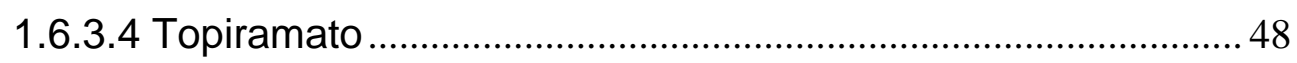

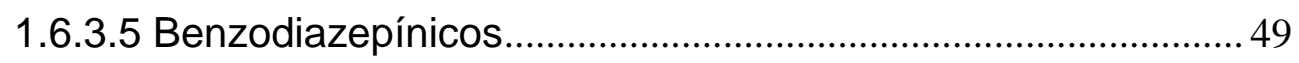

1.6.3.6 Inibidores seletivos da recaptação da serotonina .................... 49

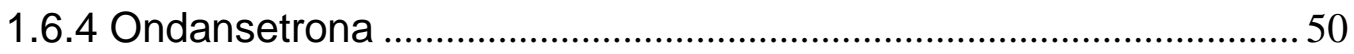

1.6.4.1 Aspectos farmacodinâmicos ................................................... 50

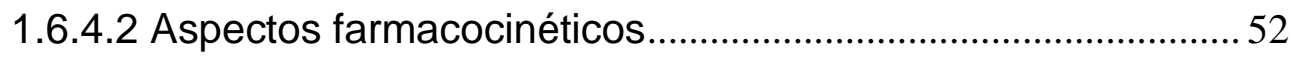

1.6.4.3 Formulação disponíveis da ondansetrona............................... 53

1.6.4.4 Segurança e efeitos colaterais .................................................. 53

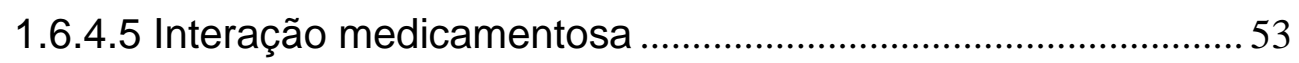

1.6.4.6 Transtornos mentais e o receptor de serotonina $5-\mathrm{HT} 3 \ldots . . . . .54$

1.6.4.7 Ondansetrona e alcoolismo ....................................................... 56

1.7 Adesão ao tratamento .............................................................................. 59

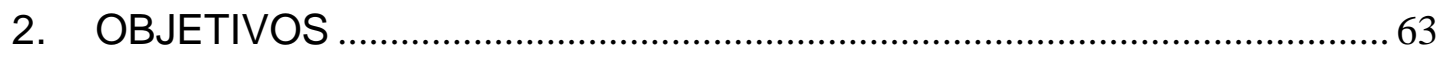

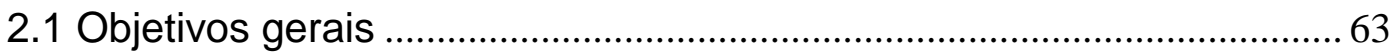

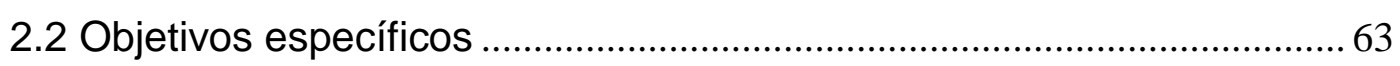

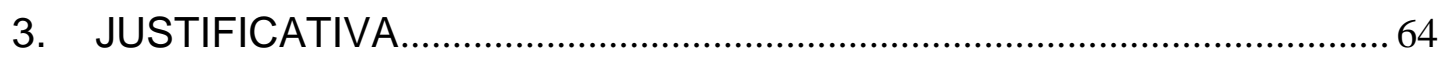

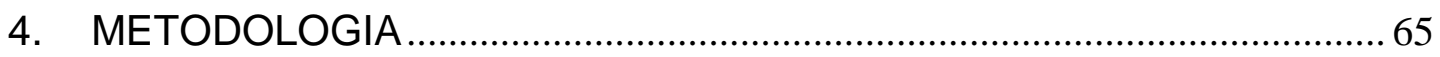

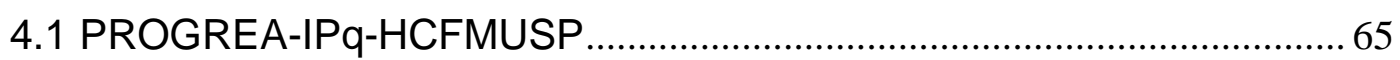

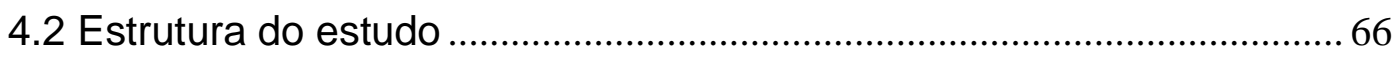

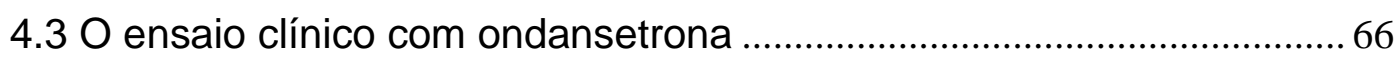

4.3.1 O local do estudo e pacientes ............................................................... 66

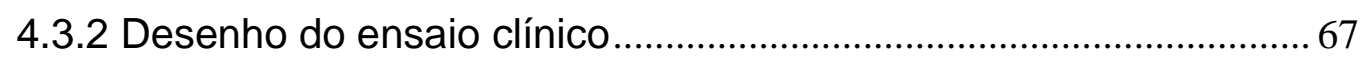

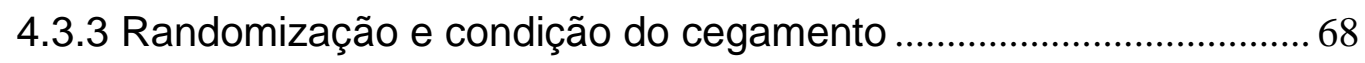

4.3.4 Considerações sobre medicamento e cartelas ................................. 69

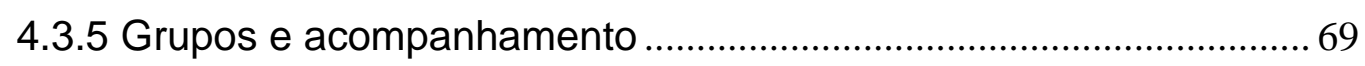

4.3.6 Critérios de eficácia do ensaio clínico ................................................ 73

4.3.7 Integridade da condição duplo-cego do estudo ............................... 75

4.3.8 Critérios de inclusão e exclusão ........................................................... 76 


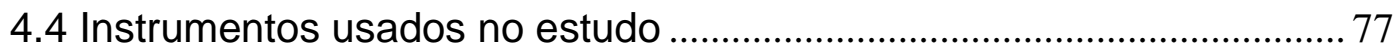

4.4.1 AUDIT (Alcohol Use Disorders Identification Test) ............................ 77

4.4.2 SADD (Short Alcohol Dependence Data)......................................... 77

4.4.3 CIWA-Ar (Clinical Institute Withdrawal Assessment for Alcohol

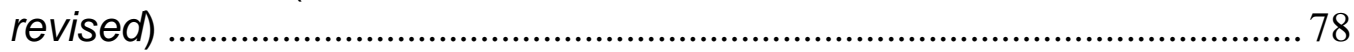

4.4.4 ESA (Escala de Seguimento para Alcoolistas).................................. 78

4.4.5 OCDS (Obsessive Compulsive Drinking Scale).............................. 79

4.4.6 Hamilton-21 (Escala de depressão Hamilton com 21 itens) ........... 79

4.4.7 Escala de efeitos colaterais UKU (Ugvald for Kliniske

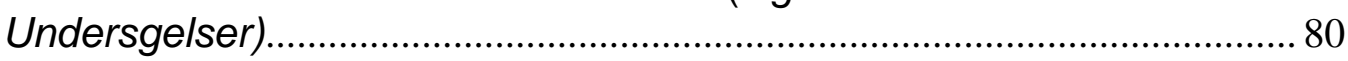

4.5 Formulação de tipologia para alcoolistas e retenção no tratamento .... 81

4.5.1 Participantes atendidos nos três ensaios ........................................... 81

4.5.2 Acompanhamento dos pacientes nos três ensaios ........................... 84

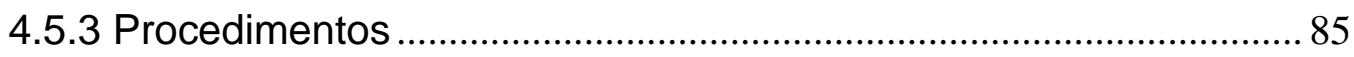

4.6 Variáveis clínicas relacionadas com a adesão ao tratamento ................ 87

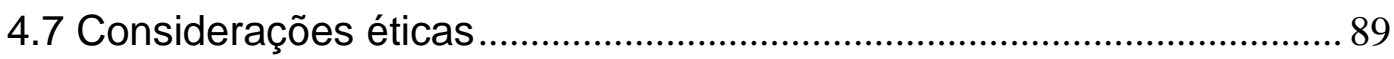

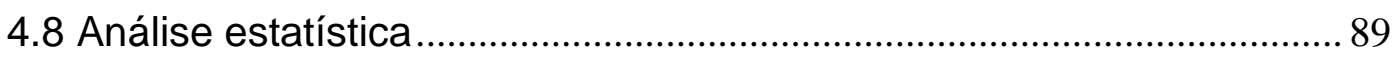

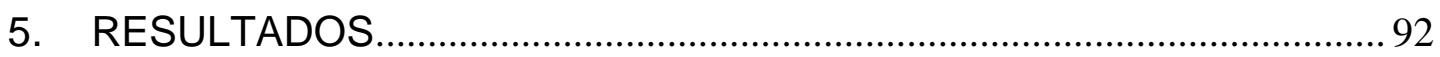

5.1 Ensaio clínico com a ondansetrona...................................................... 92

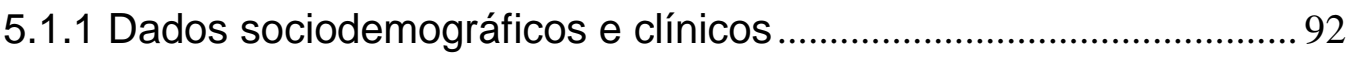

5.1.2 Marcadores biológicos de consumo do álcool...................................98

5.1.3 Tempo de abstinência continuada, tempo total de abstinência e tempo primeiro consumo pesado de álcool .............................................. 100

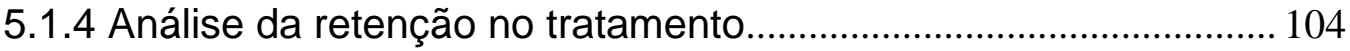

5.1.5 Percentagem de dias abstinentes e percentagem de dias com

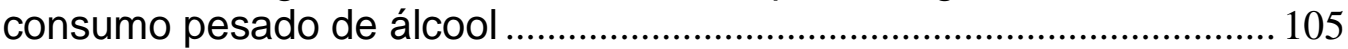

5.1.6 Segurança e tolerância da ondansetrona ....................................... 113

5.1.7 Integridade do estudo duplo-cego .................................................. 113

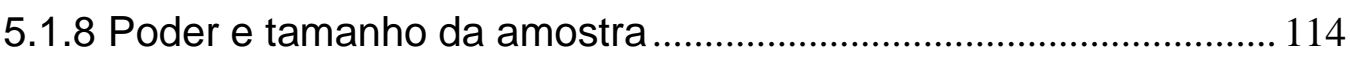

5.2 Formulação da tipologia para alcoolistas …………………………........ 115

5.2.1 Características dos participantes dos três estudos ......................... 115

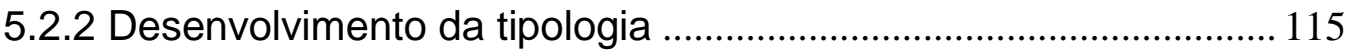

5.2.3 Característica clínica dos clusters tipo 1 e 2...................................... 118

5.2.4 Tipologia e motivos de descontinuação do tratamento ................... 121

5.2.5 Tipologia e participação nos Alcoólicos Anônimos .......................... 123

5.2.6 Tipologia do alcoolista, medicamento e participação no AA ......... 125 
5.2.7 Variáveis relacionadas à tipologia, medicamento e participação no grupo do AA

5.3 Variáveis clínicas preditoras de adesão ao tratamento 129

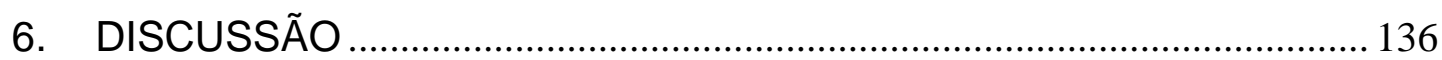

6.1 Discussão dos resultados do ensaio clínico com ondansetrona ......... 136

6.2 Discussão dos resultados da formulação da tipologia ........................... 141

6.3 Discussão dos resultados da análise de variáveis clínicas preditoras de retenção no tratamento 145

7. CONCLUSÕES

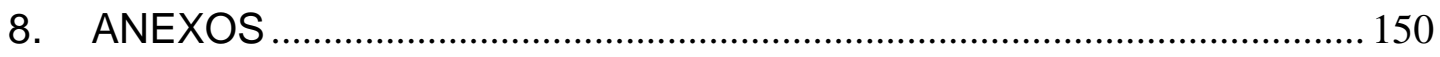

Anexo A (Carta aprovação do CAPPesq) ……………………………........ 150

Anexo B (Termo de consentimento pós-informação) ..................................... 151

Anexo C (Exames laboratoriais realizados durante o estudo).................... 154

Anexo $\mathrm{D}$ (Critérios diagnósticos para síndrome de dependência de álcool)

Anexo E (Protocolo comum do GREA, adaptado) ...................................... 156

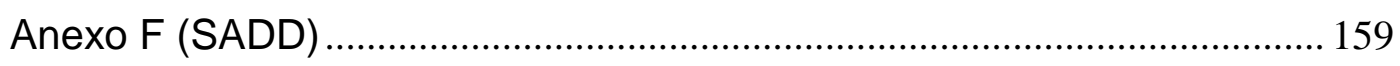

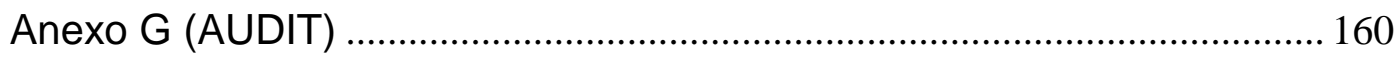

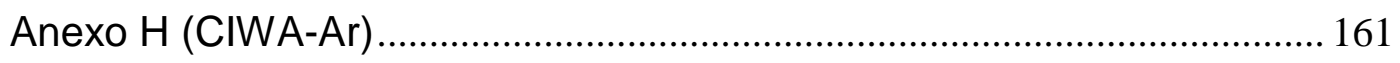

Anexo I (Escala de seguimento de alcoolistas)........................................... 162

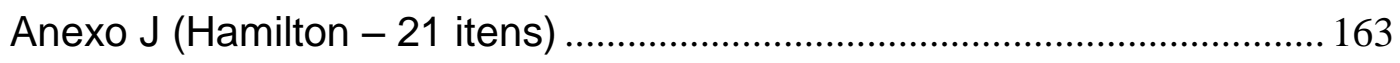

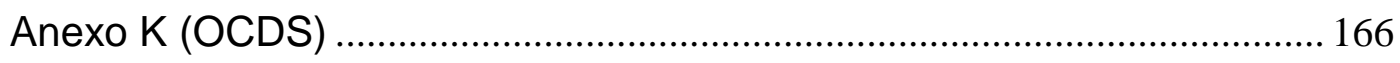

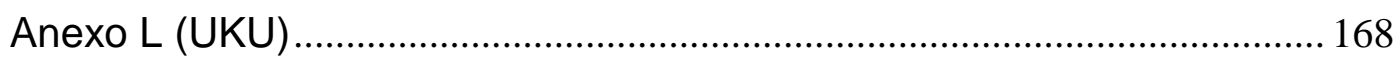

Anexo M (Artigo publicado na European Addiction Research)................... 169

Anexo N (Artigo publicado na Revista Brasileira de Psiquiatria) ................ 180

Anexo O (Artigo publicado na Addictive Behaviors) ................................... 189

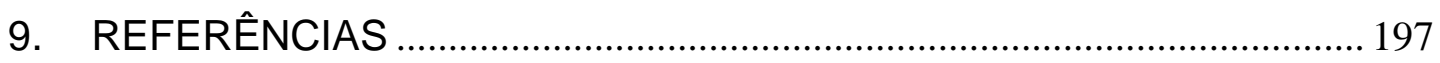


Tabela 1. Tipos de bebida e concentração de álcool etílico na bebida, expressa em percentagem.

Tabela 2. Consumo dos brasileiros quanto ao tipo de bebida e classe socioeconômica.

Tabela 3. Concentração sérica de álcool, estimada, conforme o gênero e peso, de acordo com o número de doses consumidas.

Tabela 4. Volume de álcool em cada tipo de bebida e concentração sanguínea de álcool.

Tabela 5. Correlação entre o nível de álcool sérico e as alterações mentais correspondentes à alcoolemia.

Tabela 6. Fases dos dependentes de álcool frente ao tratamento.................. 36

Tabela 7. Cronograma das consultas e distribuição de cápsulas.................. 72

Tabela 8. Características iniciais dos grupos ondansetrona e placebo......... 95

Tabela 9. Resultado dos marcadores biológicos dos pacientes que terminaram o estudo.

Tabela 10. Comparação entre as médias do tempo de abstinência continuada, tempo total de dias abstinentes e tempo para o primeiro consumo pesado do álcool, nos grupos ondansetrona e placebo, expresso em dias.

Tabela 11. Situação dos participantes quanto ao término do estudo, entre os grupos ondansetrona e placebo.

Tabela 12. Análise das características clínicas e sociodemográficas quanto à retenção no tratamento.

Tabela 13. Frequência de sintomas clínicos atribuídos à medicação nos grupos placebo e ondansetrona.

Tabela 14. Integridade do estudo, número e percentagens de impressões certas e erradas do pesquisador e participantes da pesquisa quanto ao uso da medicação testada.

Tabela 15. Distribuição e características dos pacientes dentro das duas tipologias propostas. 
Tabela 16. Características clínicas dos clusters tipo 1 e 2 proposta para os alcoolistas

Tabela 17. Motivos de descontinuação dos estudos nos clusters no geral e por grupo de medicação.

Tabela 18. Participação no AA nos clusters, no geral e por grupo de medicação.

Tabela 19. Retenção no tratamento por influência do tipo de cluster do alcoolista, da medicação e da participação no AA.

Tabela 20. Efeito da medicação, participação no $A A$ e variáveis relacionadas ao cluster, na retenção do tratamento.

Tabela 21. Características dos pacientes eleitos para análise de variáveis preditoras de retenção no tratamento.

Tabela 22. Efeito das variáveis clínicas e psicossociais na retenção do tratamento.

Tabela 23. Análise de regressão logística apenas com variáveis que mostraram prever a retenção ao tratamento.

Tabela 24. Correlação das variáveis incluídas na análise multivariada 
Figura 1. Mapa do consumo de álcool per capita no mundo, expresso em litros, no ano de 2005.

Figura 2. Distribuição do tipo de bebida destilada consumida pelo brasileiro.

Figura 3. Estrutura molecular da ondansetrona e serotonina

Figura 4. Fluxograma dos pacientes que foram convidados a participar do ensaio com ondansetrona.

Figura 5. Fluxograma dos pacientes que participaram dos estudos:

acamprosato versus placebo e topiramato e naltrexona versus placebo.

Figura 6. Fluxograma dos participantes selecionados para avaliação das variaveis, relacionadas aos pacientes, capazes de prever a aderência no tratamento.

Figura 7. Fluxograma com os participantes do ensaio com ondansetrona e placebo.

Figura 8. Curva de sobrevida de Kaplan-Meier, para primeiro consumo de álcool, nos grupos placebo e ondansetrona.

Figura 9. Curva de sobrevida de Kaplan-Meier, para primeiro consumo pesado de álcool, nos grupos placebo e ondansetrona.

Figura 10. Percentagem de dias abstinentes, durante o estudo nos grupos ondansetrona e placebo.

Figura 11. Percentagem de dias consumo pesados, durante o estudo nos grupos ondansetrona e placebo.

Figura 12. Proporção de dias abstinentes no decorrer do estudo, análise com os dados imputados, nos grupos ondansetrona e placebo.

Figura 13. Proporção de dias com consumo pesados de álcool no decorrer do estudo, análise com os dados imputados, nos grupos ondansetrona e placebo.

Figura 14. Fluxograma dos participantes dos ensaios envolvidos no estudo, de 2001 a 2010. 


\section{RESUMO}

Corrêa Filho JM. Eficácia da ondansetrona no tratamento de dependentes de álcool [tese]. São Paulo: Faculdade de Medicina, Universidade de São Paulo; 2013.

INTRODUÇÃO: A dependência de álcool é um grave problema de saúde publica no Brasil. Seu tratamento ainda é um desafio, mesmo para os melhores programas terapêuticos disponíveis. Esta dificuldade ocorre pelo pequeno número de medicamentos aprovados para o uso e também pela elevada taxa de abandono, próximo a 50\%. A ondansetrona tem surgido como uma medicação promissora para o tratamento de alcoolistas. A identificação de pacientes com maior risco de desistência do tratamento é uma estratégia para reverter essa taxa. Os objetivos deste estudo são: (a) avaliar a eficácia e segurança da ondansetrona na dose de $16 \mathrm{mg} / \mathrm{dia}$; (b) investigar variáveis clínicas e psicossociais capazes de prever maior aderência ao tratamento; (c) desenvolver uma tipologia para alcoolistas com características presentes no início do tratamento; (d) testar se os diferentes tipos podem prever o abandono ao tratamento. METODOS: Trata-se de estudo realizado em três etapas. Na primeira foi realizado ensaio clinico randomizado duplo-cego placebo controlado, com ondansetrona, por 12 semanas, desenvolvido na Universidade de São Paulo - Brasil. A amostra era composta por 102 dependentes de álcool com idade entre $18-60$ anos. A análise foi realizada com os dados brutos e com os dados imputados. $\mathrm{Na}$ segunda etapa, foi combinado o banco de dados deste estudo com os de outros dois ensaios realizados no mesmo local (acamprosato versus placebo e naltrexona, topiramato versus placebo), com número total de 332 dependentes de álcool. A partir da análise de quatro fatores clínicos (idade de início dos problemas com uso do álcool, alcoolismo familiar, gravidade da dependência do álcool e intensidade de sintomas depressivos) foi realizada a análise de cluster tipo K-Means e, após a identificação dos tipos, foi avaliada a associação destes com a adesão ao tratamento. Na última etapa, analisando apenas os participantes avaliados quanto ao desejo pelo álcool (257 alcoolistas) foi realizada uma regressão logística, com variáveis clínicas e psicossociais, para analisar a influência dessas na retenção ao tratamento. RESULTADO: A ondansetrona foi capaz de retardar o tempo para o primeiro consumo de álcool (54,7 versus 40,9 dias) e, também, o primeiro consumo pesado de álcool (58,4 versus 45,4 dias) quando comparado ao placebo. Essa droga não influenciou a percentagem de dias bebidos durante 0 estudo, mas esteve associada com menor percentagem de dias com consumo pesado de álcool (7,8\% versus $11,7 \%)$, quando comparado ao placebo, na análise de dados imputados. $\mathrm{Na}$ análise de tipologia foram identificados dois grupos de alcoolistas. O tipo de alcoolista caracterizado pelo início precoce dos problemas com álcool, maior histórico familiar de dependência, elevada gravidade de alcoolismo e poucos sintomas depressivos esteve associado a maior chance de descontinuar o tratamento, independente da medicação usada e da participação nos alcoólicos anônimos (AA). Entre as variáveis clínicas e psicossociais estudadas, ter 
idade mais elevada, participar do AA e o consumo preferencial pela cerveja foram fatores independentes associados a maior adesão ao tratamento. Maiores escores de depressão aumentaram o risco de abandono. CONCLUSÃO: A ondansetrona mostrou ser segura e bem tolerada na dose de $16 \mathrm{mg} /$ dia. Foi mais eficaz que o placebo em retardar o primeiro consumo e primeiro consumo pesado de álcool, deixou dúvida sobre seu efeito na percentagem de dias bebidos e de consumo pesado de álcool. $\mathrm{O}$ tipo de alcoolista com idade precoce de problemas com álcool, elevada dependência dessa substância, mais história familiar de alcoolismo e menos sintomas depressivos, esteve associado ao maior risco de abandono. Idade mais elevada, frequentar o AA e ter preferência pela cerveja aumenta a chance de completar o tratamento proposto.

Descritores: 1.Alcoolismo 2.Ondansetrona 3. Desistência do tratamento 4.Análise por conglomerados 5.Psicotropicos 6.Ensaio clínico 7. Transtorno relacionados ao uso de substâncias 8.Alcoólicos anônimos 


\section{SUMMARY}

Corrêa Filho JM. Efficacy of ondansetron for the treatment of alcohol dependent outpatients [thesis]. São Paulo: "Faculdade de Medicina, Universidade de São Paulo", 2013.

INTRODUCTION: Alcohol dependence is a serious public health problem in Brazil. Its treatment remains a challenge, even for the best available treatment programs. This difficulty is due to the small number of drugs approved for use and also the high dropout rates, close to $50 \%$. Ondansetron has emerged as a promising drug for the treatment of alcoholics. The identification of patients with increased risk of treatment discontinuation is a strategy to reverse these rates. The aims of this study are: (a) to evaluate the efficacy and safety of ondansetron in a dose of $16 \mathrm{mg} /$ day; (b) to investigate clinical and psychosocial variables that could predict treatment retention, (c) to develop a typology of alcoholics based on clinical factors present at the beginning of the treatment; and (d) to test if different types of alcoholics could predict the higher withdrawal from treatment. METHODS: This study was conducted in three stages. Firstly, a randomized, double-blind, placebocontrolled clinical trial was conducted with ondansetron for 12 weeks, developed at the University of São Paulo - Brazil. The sample consisted of 102 alcoholics aged between 18 and 60 years old. The analysis was performed by using only the sample of adherents and an imputed sample. Secondly, the database of this study was combined with two other clinical trials that were carried out in the same setting (acamprosate versus placebo, and topiramate, naltrexone versus placebo), with a final sample size of 332 alcohol dependents. From the analysis of four clinical factors (problem drinking onset age, family alcoholism, severity of alcohol dependence and intensity of depressive symptoms) a K-means cluster analysis was performed to identify types of alcoholics. In addition, the association between the resulting types of alcoholics and treatment retention was verified. Thirdly, using only the participants who were evaluated for craving on alcohol (257 alcoholics), a logistic regression analysis was run with clinical and psychosocial variables as independent variables to analyze their influence on treatment retention. RESULTS: Ondansetron was able to delay the first alcohol consumption (54.7 versus 40.9 days) and the first heavy alcohol consumption (58.4 versus 45.4 days) compared to placebo. Ondansetron did not have effect on the percentage of drinking days. However, ondansetron was associated with a lower percentage of days with heavy alcohol consumption $(7.8 \%$ versus $11.7 \%$ ) in an imputed sample, when compared to placebo. Two types of alcoholics were identified. The type characterized by earlier problem drinking onset age, more family alcoholism, high severity of alcoholism, and fewer depressive symptoms, was associated with a greater chance of discontinuing treatment regardless of medication used and participation in alcoholic anonymous groups (AA). Out of the clinical and psychosocial variables, older age, AA attendance, and beer preference drinkers were independent factors associated with higher treatment retention. Higher scores on depression also increased the risk of dropout. 
CONCLUSION: Ondansetron showed to be safe and well tolerated at the dose of $16 \mathrm{mg} /$ day. It was more effective than placebo in delaying both the first use and the first heavy alcohol consumption. In addition, ondansetron was not effective in decreasing the percentage of drinking days throughout this study. The type of alcoholics characterized by earlier problem drinking onset age, more family alcoholism, high severity of alcoholism and fewer depressive symptoms, was associated with greater risk of dropout. Separately, the variables higher age, AA attendance, and beer preference increased the chance of completing the proposed treatments.

Descriptors: 1.Alcoholism 2.Ondansetron 3.Patient dropout 4.Cluster analysis 5.Psychotropic drugs 6.Clinical trial 7.Substance-related disorders 8.Alcoholics anonymos. 


\section{INTRODUÇÃO}

\subsection{Histórico do consumo de álcool}

Os primeiros indícios do consumo do álcool, produtos fermentados, por animais herbívoros foram encontrados em fósseis, que datam do período cretáceo (há 100.000 anos). O primeiro contato do homem com essas bebidas alcoólicas parece ter ocorrido no período Paleolítico, como detectado em vasos dessa época (Viala-Artigues e Mechetti, 2003).

A capacidade de manipular compostos para produzir a bebida alcoólica surgiu há 8000 anos antes de Cristo, conforme cerâmicas encontradas na cidade de Jihau - China, as quais apontam para produtos que apresentavam graduação alcoólica entre cerveja e vinho (Cheng, 2010).

Em toda a história da humanidade, o álcool tem sido retratado como parte do cotidiano das populações, estando associado a rituais religiosos e eventos sociais. Na Bíblia encontra-se uma passagem descrevendo a intoxicação alcoólica de Noé, após o dilúvio, “... foi a primeira pessoa que fez uma plantação de uvas. Um dia Noé bebeu muito vinho, ficou bêbado e se deitou nu dentro da sua barraca" (Sociedade Bíblica do Brasil, 2005).

Inicialmente, as bebidas tinham conteúdo alcoólico baixo, já que dependiam exclusivamente do processo de fermentação (vinho e cerveja). Com o advento do processo de destilação, introduzido na Europa pelos árabes na Idade Média, surgiram novos tipos de bebidas alcoólicas com teor etílico elevado, que foram incorporados aos hábitos europeus. Nessa época, esses tipos de bebidas passaram a ser considerados como um remédio para todas as doenças, pois "dissipavam as preocupações mais rapidamente do que o vinho e a cerveja, além de produzirem um alívio mais eficiente da dor" (Gately, 2008).

A partir da Revolução Industrial, registrou-se um grande aumento na oferta desse tipo de bebida, contribuindo para um maior consumo e, consequentemente, gerando um aumento no número de pessoas que apresentavam algum problema devido ao uso excessivo de álcool. A 
preocupação com os problemas decorrentes do abuso de bebida alcoólica já estava presente há mais de 3.000 anos - com leis da antiga Mesopotâmia, que regulavam a venda de bebidas para pessoas embriagadas (Anthony, 2009).

Somente em 1952, o alcoolismo foi reconhecido como doença, sendo colocado como um transtorno mental no Manual de Diagnóstico e Estatística, na sua primeira versão (DSM-I). Foi reconhecido como doença pela Organização Mundial de Saúde, na oitava edição do Código Internacional de Doenças (CID-8), em 1969. A dependência de álcool foi caracterizada pelo uso compulsivo de bebidas alcoólicas e pela manifestação de sintomas de abstinência, após a cessação do uso de álcool (Jerome, 1993).

Na metade do século XIX aumentou o interesse de pesquisadores em estudar os problemas relacionados ao consumo do álcool. A dipsomania foi descrita pela primeira vez, como desejo anormal e involuntário em relação ao álcool por Bruhl-Cramer (Rússia). Esquirol descreveu o alcoolismo como uma monomania sem delírio. O conceito de doença crônica devido à intoxicação constante, que leva a sintomas psiquiátricos e somáticos (ou mistos), surgiu com Magnus Huss (Laranjeira e Nicastri, 1996).

Em 1960 Jellinek elaborou uma classificação dos alcoolistas, iniciando o conceito de tipologia no alcoolismo, ao dividi-los em cinco tipos:

a) Alcoolismo alfa representa a dependência psicológica ao álcool. Existe perda de controle sobre o consumo, mas a abstinência pode ser alcançada. Problemas envolvendo relação interpessoal, trabalho e família costumam estarem presentes. A progressão para dependência física é evitável.

b) Alcoolismo beta é caracterizado por não existir dependência física ou psicológica. Problemas físicos associados ao uso crônico do álcool estão presentes (como a cirrose, gastrite ou pancreatite). Este tipo de alcoolismo tende acontecer em indivíduos de culturas com consumo pesado de álcool e com alimentação inadequada. 
c) Alcoolismo gama é marcado por desenvolvimento de tolerância, mudanças físicas que levam à síndrome de abstinência e à perda de controle. Neste tipo, houve a progressão da dependência psicológica para a física, sendo marcante a presença da tolerância e dos sintomas de abstinência, já existindo o descontrole com o consumo de bebida. Esta fase é devastadora em termos de disfunção social e física. Esta variante é a mais comum entre todas.

d) Alcoolismo delta é muito similar ao tipo gama, existe dependência física e psicológica, mas o alcoolista é capaz de controlar, com esforço, o consumo da bebida.

e) Alcoolismo ípsilon é descrito como episódico. Na percepção de Jellinek é uma forma diferente das outras. É um tipo de bebedeira esporádica, que segundo ele, seria uma espécie própria de alcoolismo.

Em seu livro "The Disease Concept of Alcoholism" ele reconhece que sua classificação pode não estar totalmente correta, especulando que o tipo alfa e ípsilon podem, inclusive, serem sintomas de outras doenças (Jellinek, 1960).

\subsection{Aspectos gerais do álcool}

O álcool etílico é o elemento que caracteriza as bebidas alcoólicas. Conforme o processo de produção das bebidas, elas podem ser divididas em três grandes grupos: bebidas fermentadas, como vinho, cerveja e espumante, produzidas pela fermentação de carboidrato (existente na uva e cevada, por exemplo), cujo processo produz as bebidas com menor teor alcoólico; bebidas destiladas que são mais recentes e que produzem compostos com alta concentração de álcool, como a cachaça, vodca, conhaque e uísque; bebidas alcoolizadas que são fermentadas e que passam pela adição de álcool para aumentar a concentração de etanol, por exemplo, o vinho do porto (Edwards et al., 1999). 
As bebidas obtidas a partir da destilação apresentam o teor mais elevado de álcool. O absinto é a bebida que pode apresentar a maior concentração de álcool, 70\%. Como no Brasil existe um limite para a concentração alcoólica, essa bebida é modificada e vendida com percentagem menor de etanol. Na tabela 1, encontra-se a concentração alcoólica das principais bebidas comercializadas.

Tabela 1. Tipos de bebida e concentração de álcool etílico na bebida, expressa em percentagem.

\begin{tabular}{l|c}
\hline \hline Bebida & Concentração de álcool \\
Cérveja & 3,5 a $5 \%, \ldots, \ldots, \ldots, \ldots, \ldots, \ldots, \ldots, \ldots, \ldots, \ldots, \ldots, \ldots, \ldots, \ldots$ \\
\hline Vinho & 10 a $15 \%$ \\
\hline Espumante & $20 \%$ \\
\hline Vinho do Porto & 38 a $53 \%$ \\
\hline Aguardente & 35 a $60 \%$ \\
\hline Vodca & 40 a $50 \%$ \\
\hline Uísque & 45 a $48 \%$ \\
\hline Conhaque & $50 \%$ \\
\hline Licores & $59 \%$ \\
\hline Absinto & \\
\hline \hline
\end{tabular}

Modificada a partir de Lima (2003).

\subsection{Epidemiologia}

A cada ano, cerca de $40 \%$ da população mundial acima de 15 anos consome bebida alcoólica, o equivalente a dois bilhões de pessoas. Por ano, estima-se que morrem 2 a 2,5 milhões de pessoas devido ao uso de álcool (mortes provocadas por intoxicações agudas, cirrose hepática induzida pelo 
álcool, violência e colisões de automóveis). A proporção entre as duas estimativas acima, indica que a cada ano as consequências nocivas do uso do álcool são responsáveis por 1,2 mortes atribuíveis ao álcool para cada 1.000 consumidores. O custo anual estimado do uso nocivo encontra-se entre $0,6 \%$ até $2 \%$ do produto interno bruto (PIB) global. Esses custos estão distribuídos pelos países do mundo, frequentemente relacionados ao consumo per capita de álcool (figura 1).

O consumo de álcool, no ano de 2005, foi de 6,13 litros de álcool puro por pessoa com idade maior que 15 anos. Uma parcela significativa desse consumo é decorrente da fabricação domiciliar de bebidas - 28,6\% ou 1,76 litros. As bebidas mais consumidas no mundo são os destilados (45,7\%). Em alguns países chegam a compreender $71 \%$ da bebida consumida, como nos países integrantes da já extinta União Soviética. As cervejas ocupam a segunda colocação com $35,5 \%$. Em terceiro, estão os vinhos com $8,6 \%$ do consumo mundial, mas nos países produtores de vinho as taxas podem chegar a $12 \%$ na América do Sul e 26,4\% na Europa (World Health Organization, 2011b).

O álcool é uma das poucas drogas psicotrópicas que tem seu consumo admitido e incentivado pela sociedade. A mortalidade e a morbidade associadas ao consumo de bebidas alcoólicas superam aquelas associadas ao tabagismo. Calcula-se que no mundo $3,2 \%$ de todas as mortes e $4 \%$ dos Anos de Vida Saudáveis Perdidos por Incapacitação (DALYs - Disability-Adjusted Life Years) sejam atribuíveis ao uso nocivo do álcool. Em países em desenvolvimento, entre os quais está o Brasil, o álcool é o fator de risco que mais contribui para a carga de doenças, sendo responsável por 6,2\% das DALYs (World Health Organization, 2002). 
Figura 1. Mapa do consumo de álcool per capita no mundo, expresso em litros, no ano de 2005.

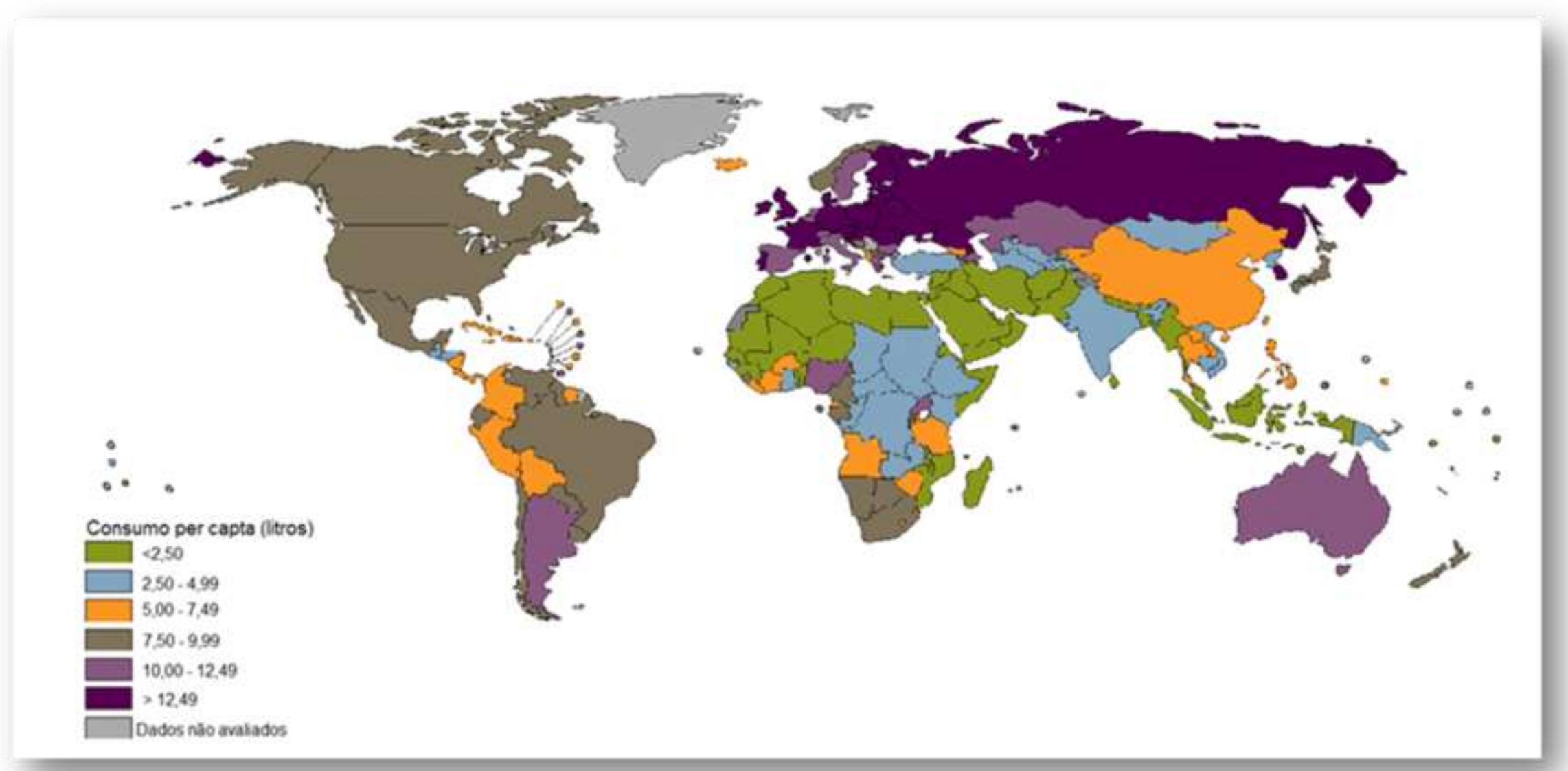

Modificada a partir de Public Health Information and Geographic Information Systems (World Health Organization, 2005). 
O consumo abusivo do álcool é uma ameaça particularmente grave para os homens. Ele é o principal fator de risco para mortes em homens entre 15 - 59 anos, devido principalmente aos agravos para a saúde do uso do álcool, violência e doença cardiovascular. $O$ álcool é responsável por $6,2 \%$ das mortes em homens e $1,1 \%$ entre as mulheres. A bebida etílica ocasiona maior carga de problemas ao longo da vida nos homens - com $7,4 \%$ para eles e $1,4 \%$ para as mulheres. Ser homem produz quatro vezes mais chance de beber pesado - o que pode explicar em parte a maior mortalidade e taxa de incapacidade (World Health Organization, 2011b).

Nos Estados Unidos da América (EUA) a dependência de álcool compromete 10 a $14 \%$ da população durante a vida, sendo que o sexo masculino apresenta maior propensão para essa doença (Gaburtt et al., 1999; Robins et al., 1984). No ano de 2007 , foi encontrada uma prevalência entre os americanos para o alcoolismo de $12,5 \%$ na vida e 3,8\% nos últimos 12 meses (Hasin et al., 2007). A União Europeia é o maior consumidor de álcool do mundo. Em média, consomem-se três doses de álcool por dia para cada habitante maior que 15 anos de idade. Em Portugal, 3,2 a 5,4\% dos habitantes podem ser diagnosticados como dependentes de álcool. $\mathrm{Na}$ França, acredita-se que $3,4 \%$ do total de 58,3 milhões de habitantes sejam alcoolistas (World Health Organization, 2011a).

O Brasil apresenta posição intermediária no consumo per capita de álcool, entretanto possui números preocupantes quando analisado o padrão de consumo do álcool. Ele tem elevada percentagem de beber pesado episódico, sendo visto em 5,5 a 15,5\% na população adulta. Em populações específicas, como estudantes, pode-se chegar a valores alarmantes - $36,4 \%$ (Silveira et al., 2008).

Na primeira análise populacional sobre consumo de droga feita em domicílio, que incluiu 107 cidades com mais de 200.000 habitantes, encontrou-se uma taxa de consumo de álcool na vida de 68,7\%, com ligeiro predomínio para os homens $(77,3 \%$ contra $60,6 \%$ das mulheres). Foi estimado que 2,5 milhões de pessoas residentes nas cidades estudadas apresentavam critérios para dependência de álcool, correspondendo a 
$11,2 \%$ da população estudada. A prevalência de alcoolismo em homens foi três vezes superior à feminina (17,1 versus 5,7 , respectivamente) (Carlini et al., 2001).

Com a realização do segundo levantamento domiciliar em 2005, houve a primeira análise de tendência da população brasileira. Evidenciouse o aumento na prevalência de uso de álcool na vida de $68,7 \%$ para $74,6 \%$ dos entrevistados. Entretanto, a estimativa de dependência de álcool nos dois estudos não mostrou diferença significativa $(11,2 \%$ do primeiro versus $12,3 \%$ do segundo estudo). Uma explicação para o aumento na taxa de uso de álcool na vida pode ser a extensa campanha publicitária, feitas pelas companhias de cervejas na mídia televisiva (Fonseca et al., 2010; Carlini et al., 2007).

No Brasil, existem vários levantamentos sobre o uso de drogas psicotrópicas, em estudantes do ensino fundamental e médio (com idade entre 10 e 18 anos), sendo que o mais recente deles mostra que $65,2 \%$ dos entrevistados haviam consumido álcool na vida e $11,7 \%$ destes estudantes bebe frequentemente (Galduroz et al., 2005). No segundo levantamento domiciliar, os jovens com idade entre 18 a 24 anos, faixa etária dos estudantes universitários, Carlini et al. (2007) encontraram uma prevalência de uso de álcool na vida 78,6\% e de problemas relacionados ao consumo do álcool de $12 \%$. O primeiro levantamento com estudantes universitários, realizado nas 27 capitais brasileiras, mostrou que o uso de álcool na vida era de $86,2 \%$, taxa maior que a encontrada na população da mesma faixa etária, como citado acima. Também mostrou que $60,5 \%$ dos estudantes deste levantamento tinham consumido álcool no ultimo mês, um indicativo de consumo recorrente de álcool. A análise do consumo entre os universitários mostrou um beber pesado episódico de $35,7 \%$ no ultimo ano e de $25,3 \%$ no último mês. A análise dos gêneros entre os estudantes universitários mostrou proporção muito próxima a 1:1, não indicando uma maior exposição de um dos gêneros. O padrão de consumo de álcool foi diferente para o beber pesado episódico, com a ocorrência de $43,7 \%$ nos homens e de $29 \%$ 
nas mulheres nos últimos 12 meses e de 31,3\% nos homens e 20,3\% nas mulheres no ultimo mês (Andrade et al., 2010).

Um estudo realizado por Noto et al. (2002) analisando 726.429 internações por uso de psicotrópicos realizadas no território nacional, entre 1988 e 1999, mostrou que o álcool foi responsável por cerca de 90\% destas. No período houve uma tendência de queda de internações por problemas por álcool de 95,3\% (1988) para 84,5\% (1999). Outro estudo, analisando 6.048 internações no Distrito Federal, entre 2000 e 2009, também mostrou uma tendência de queda, de 75,6\% (2000) para 62,2\% (2009), das internações por álcool. Essa tendência de declínio das internações por álcool pode ser atribuída à melhora de estratégias de tratamento ambulatorial e, também, pelo aumento nas internações por outras drogas (Passos, 2010).

O primeiro estudo sobre o padrão de consumo de álcool da população brasileira foi feito por Laranjeira et al. (2007). Nesse levantamento, 52\% dos adultos, com mais de 18 anos, consomem bebida alcoólica ao menos uma vez por ano; nos homens este valor chega a $65 \%$ e entre as mulheres $41 \%$. Entre os adultos que bebem $60 \%$ dos homens e $33 \%$ das mulheres consumiram cinco ou mais doses de álcool no último ano. Entre os homens $11 \%$ bebem álcool todos os dias, $27 \%$ usam frequentemente (1 a 4 vezes por semana). As mulheres fazem uso de álcool com menor frequência, apenas $2 \%$ bebem todos os dias e $11 \%$ usam frequentemente. Outro dado interessante apresentado nesse levantamento está na maior porcentagem de pessoas que bebem serem da classe A e B e estar na Região Sul, enquanto, o maior consumo de doses a cada vez que se bebe ter sido encontrado nos Estados do Norte, do Centro-Oeste e do Nordeste nos integrantes da classe E. Esse estudo apresentou a cerveja como a bebida mais consumida pelo brasileiro (61\%), seguido pelo vinho $25 \%$, destilados $12 \%$ e bebidas ice (preparados de destilados com suco ou refrigerantes) $2 \%$. O tipo de bebida consumida tende a variar conforme as classes socioeconômicas, com maior frequência o vinho é consumido pelas $A$ e $B$ e de destilados pela classe $E$ (tabela 2). O destilado mais bebido no Brasil foi a cachaça, relatada em $66 \%$ dos casos (figura 2 ). 
Tabela 2. Consumo dos brasileiros quanto ao tipo de bebida e classe socioeconômica.

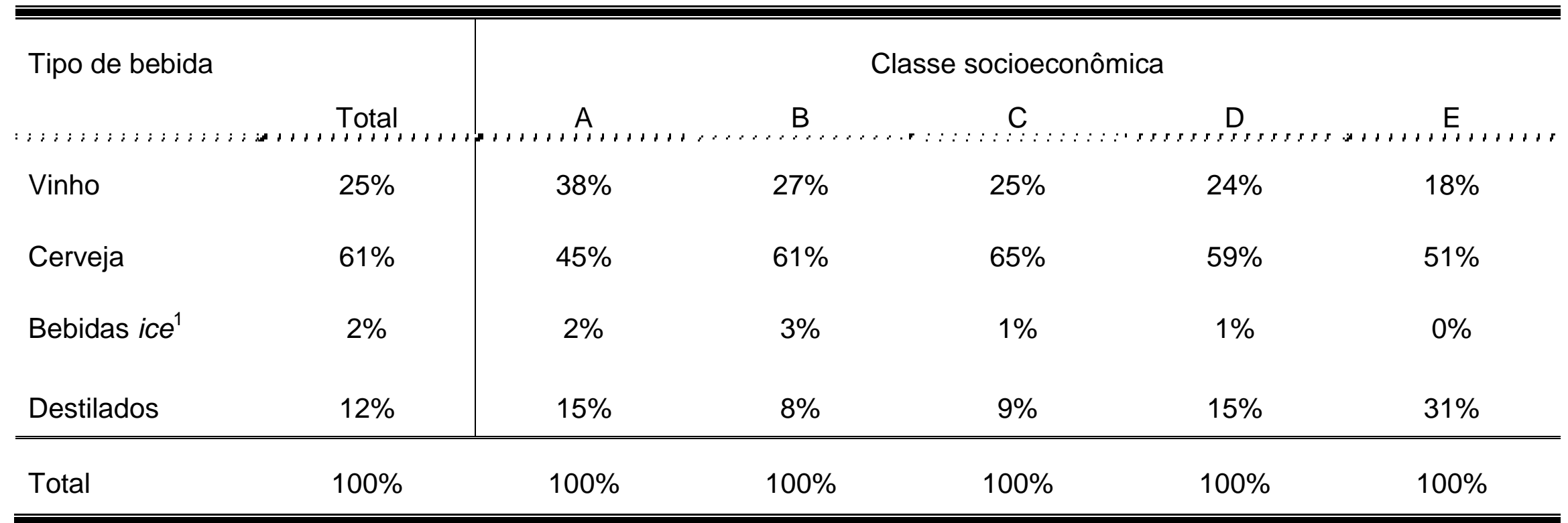

'1 Bebidas ice são as combinações de sucos industrializados ou refrigerantes com destilados. Fonte Laranjeira et al. (2007). 
Figura 2. Distribuição do tipo de bebida destilada consumida pelo brasileiro.

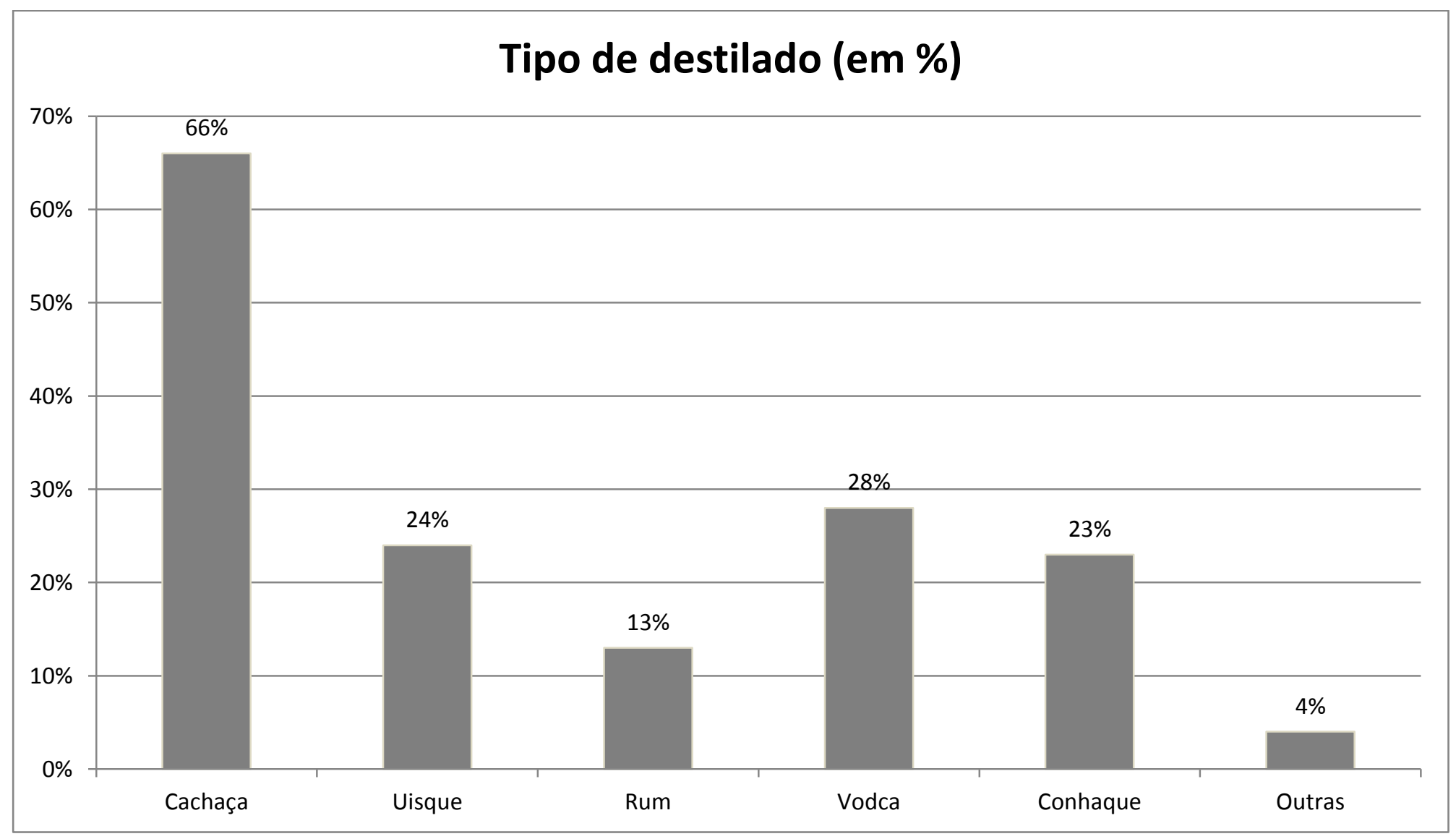

Modificado a partir de Laranjeira et al. (2007) 


\subsection{Farmacocinéticas do álcool}

O álcool etílico é uma molécula pequena, lipossolúvel e absorvida em velocidades diferentes: através do estômago (relativamente lento), intestino delgado e cólon (nesses mais rápidos). O tempo para atingir a concentração sanguínea máxima é de 30 a 90 minutos. Distribui-se pelo corpo e vários tecidos, como coração, cérebro e músculos (Van Sassenbroaeck et al., 2003).

O índice de absorção do álcool é influenciado de duas maneiras: fatores que aceleram a absorção do álcool (alta concentração de álcool nas bebidas, presença de dióxido de carbono e bicarbonato em bebidas efervescentes); fatores que retardam a absorção do álcool (presença de alimento no estômago especialmente carboidrato, temperatura corporal baixa, exercício físico e presença de açúcar nas bebidas alcoólicas) (Milton, 2006).

A concentração sanguínea do álcool pode variar de acordo com o gênero (mulheres têm volemia sanguínea menor), estatura, composição corporal, exposição prévia ao etanol, tipo de bebida e uso de medicação que altere o esvaziamento gástrico (Auty e Branch, 1977).

De uma maneira geral para cada dose de álcool ingerida espera-se que a elevação do álcool siga um padrão, conforme o sexo e peso do sujeito (tabela 3).

Cerca de $90 \%$ do etanol ingerido é metabolizado e o restante é eliminado pelos rins e pelo ar expirado. As concentrações hepáticas do álcool são maiores que o restante do corpo, devido a ele receber o sangue da veia porta que traz as substâncias absorvidas pelo estômago e intestino. O metabolismo do etanol ocorre quase que totalmente no fígado, principalmente por uma via que envolve oxidações sucessivas, inicialmente a acetaldeído e, em seguida, a ácido acético. Como o etanol é, tipicamente, consumido em altas doses, isto representa uma carga substancial para os sistemas oxidativos do fígado, os quais exibem uma cinética de saturação, de tal forma que a fração do álcool etílico metabolizada diminui, à medida 
que a concentração de etanol que chega ao fígado aumenta. Nessas situações nada incomuns, muito do álcool etílico não metabolizado chega à circulação sanguínea, como apresentado na tabela 4.

A capacidade de depuração do etanol em pessoas saudáveis é de $15 \mathrm{mg}$ de álcool por $100 \mathrm{ml}$ de sangue por hora. Existem variações individuais, entre elas, as variações da eficiência das enzimas hepáticas. Bebedores pesados periodicamente tendem a acelerar a metabolização do álcool, a menos que exista comprometimento da integridade do fígado (Saunders e Paton, 1981).

\subsubsection{Efeito do álcool no sistema nervoso central}

Cada vez mais, o alcoolismo é entendido como doença crônica, associada à alteração da neurotransmissão cerebral. Esses efeitos decorrem da ingestão aguda de etanol, e também, de mudanças neuroadaptativas da exposição prolongada ao álcool etílico.

\subsubsection{Anatomia da via da recompensa}

O sistema da recompensa (ou sistema dopaminérgico) está presente em todos os mamíferos, dos mais primitivos até o ser humano. Esse sistema tem participação fundamental na busca de estímulos causadores de prazer (tais como: alimentação, sexo, descontração como assistir a um filme, conversa com amigos e apreciar uma melodia). Com o reforço positivo obtido durante as experiências prazerosas, o organismo é levado a buscálas repetidas vezes. Cria-se uma memória específica para isso. O sistema de recompensa, desse modo, é um importante mecanismo de preservação (Vasconcelos et al., 2002). 
Tabela 3. Concentração sérica de álcool, estimada, conforme o gênero e peso, de acordo com o número de doses consumidas.

\begin{tabular}{|c|c|c|c|c|c|c|c|c|c|}
\hline Doses & Gênero & $40 \mathrm{~kg}$ & $45 \mathrm{~kg}$ & $50 \mathrm{~kg}$ & $60 \mathrm{~kg}$ & $70 \mathrm{~kg}$ & $80 \mathrm{~kg}$ & $90 \mathrm{~kg}$ & $100 \mathrm{~kg}$ \\
\hline \multirow[t]{2}{*}{1} & Määculino" & - & $\because:$ & 0,30 & 0,25 & 0,25 & 0,20 & 0,15 & 0,15 \\
\hline & Feminino & 0,45 & 0,40 & 0,35 & 0,30 & 0,25 & 0,25 & - & - \\
\hline \multirow[t]{2}{*}{2} & Masculino & - & - & 0,60 & 0,50 & 0,45 & 0,40 & 0,30 & 0,25 \\
\hline & Feminino & 0,90 & 0,80 & 0,70 & 0,60 & 0,50 & 0,45 & - & - \\
\hline \multirow[t]{2}{*}{3} & Masculino & - & - & 0,95 & 0,75 & 0,65 & 0,55 & 0,50 & 0,45 \\
\hline & Feminino & 1,40 & 1,25 & 1,10 & 0,95 & 0,75 & 0,65 & - & - \\
\hline \multirow[t]{2}{*}{4} & Masculino & - & - & 1,25 & 1,00 & 0,90 & 0,75 & 0,65 & 0,60 \\
\hline & Feminino & 1,85 & 1,65 & 1,50 & 1,25 & 1,00 & 0,90 & - & - \\
\hline
\end{tabular}

Adaptada a partir de Van-Thiel e Gavaler (1988). A alcoolemia é expressa em gramas de álcool por litro de sangue. Uma dose equivale a $350 \mathrm{ml}$ de cerveja, $120 \mathrm{ml}$ de vinho ou $40 \mathrm{ml}$ de destilado. 
Tabela 4. Volume de álcool em cada tipo de bebida e concentração sanguínea de álcool.

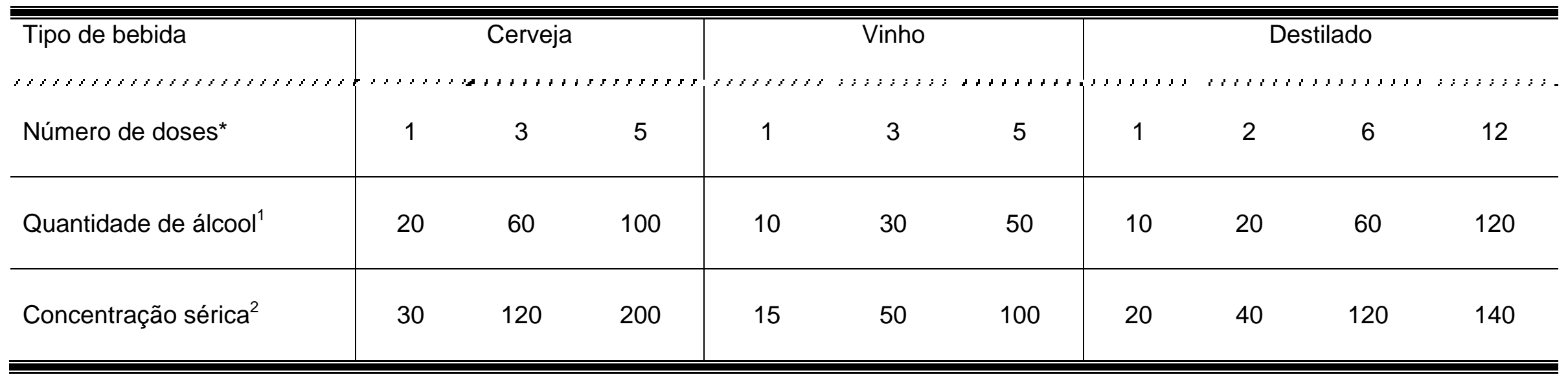

Modificada a partir de Saunders e Paton (1981). * Dose padrão para cada tipo de bebida (correspondendo a $350 \mathrm{ml}$ de cerveja, $140 \mathrm{ml}$ de vinho ou $40 \mathrm{ml}$ de destilado), ${ }^{1}$ Quantidade de álcool para cada dose, expressa em gramas de álcool, ${ }^{2}$ Concentração sérica do álcool esperada para cada dose consumida, expressa em mg de álcool/100ml de sangue. 
A dopamina é o neurotransmissor sintetizado dentro do sistema de recompensa. Para sua síntese é necessária a presença do aminoácido tirosina. Por meio da enzima tirosina hidroxilase, a tirosina é transformada em DOPA (3,4-hidroxifenilalanina). A dopamina tem sua origem a partir da descarboxilação da DOPA. Em seguida, a dopamina é armazenada nas vesículas dos terminais pré-sinápticos, para ser liberada na fenda após um estímulo neuronal. Esse estímulo pode ser a torta predileta, um carinho, uma conversa agradável com amigos, enfim, situações que certamente valerão a pena serem repetidas (Enoch, 2008).

Uma vez liberada na fenda, a dopamina atua sobre os receptores dopaminérgicos produzindo uma sensação de bem-estar. Logo após a ligação com os receptores dopaminérgicos, ela é retirada da fenda. Parte da dopamina é recaptada (pela bomba de recaptação de dopamina) e estocada no neurônio pré-sináptico para ser reutilizada. Outra parcela é destruída por enzima ou dissolvida pela fenda (Ross e Peselow, 2009).

O sistema dopaminérgico é de grande interesse para o entendimento da neurobiologia da dependência química. $O$ trato mesolímbicomesocortical, que se projeta a partir da área tegmental ventral para a maior parte do córtex frontal (funções psíquicas superiores) e sistema límbico (emoção), parece ser a via relacionada à recompensa. Estudos têm demonstrado relação íntima entre algumas estruturas cerebrais e a recompensa. $\mathrm{O}$ nucleus accumbens e a área tegmental ventral parecem moderar o estímulo à recompensa, induzido por substâncias psicoativas (Biramijamal et al., 2010).

Grande parte da propriedade aditiva das drogas está na ativação do sistema dopaminérgico. Isso pode ser feito de modo direto ou indireto. Substâncias psicoativas como a cocaína e a anfetamina agem diretamente sobre esse sistema, enquanto a nicotina, álcool e os opiáceos estimulam a via dopaminérgica indiretamente. As causas naturais que normalmente estimulam o sistema da recompensa chegam a aumentar em até $100 \%$ sua atividade. Na vigência de substâncias psicoativas, no entanto, essa atividade pode ser 1000 vezes maior (Ross e Peselow, 2009). 


\subsubsection{Neurobiologia do álcool}

O álcool é um depressor do sistema nervoso central, sua ação na via da recompensa, ao contrário de outras drogas, não ocorre pelo estímulo direto no sistema dopaminérgico. Possivelmente, alguns dos seus efeitos são mediados, principalmente, por um mecanismo mais específico, envolvendo receptores glutamatérgicos (NMDA) e gabaérgicos, sistemas serotoninérgicos (5-HT), opióides e dopaminérgicos.

Em relação ao efeito dos neurotransmissores, o etanol reduz a atividade do receptor de glutamato NMDA (N-metil-D-aspartato), bem como inibe a produção do segundo mensageiro (GMPc - guanosina monofosfato cíclico) induzido por este receptor. Com o uso crônico de etanol ocorre aumento dos sítios de ligação do glutamato nos receptores NMDA, bem como um "up-regulation" (termo usado para indicar o aumento no número de receptores). A partir desse substrato pode-se elucidar a hiperatividade glutamatérgica que ocorre na síndrome de abstinência alcoólica. Outros receptores de glutamato, o Kainato e AMPA (ácido alpha-amino-3-hidroxi-5metil-4-isoxazol-propiônico), também sofrem a inibição induzida pelo consumo crônico de etanol, embora em menor escala do que o NMDA (Johnson, 2008).

O etanol potencializa a ação do GABA (ácido gama-amino-butírico), que é o principal neurotransmissor inibitório do sistema nervoso central. Os receptores GABA sofrem modulação alostérica por diferentes drogas, entre elas benzodiazepínicos, barbitúricos, anestésicos, neuro-esteroides endógenos e o álcool. A ativação do receptor GABA, por essas substâncias, produz efeitos similares, como: efeito ansiolítico, sedativos hipnóticos, anticonvulsivante, incoordenação motora e prejuízo cognitivo. O uso crônico de álcool induz tolerância cruzada do benzodiazepínico e barbitúrico. $O$ etanol atua sobre os receptores $G_{A B A}$ de maneira semelhante aos benzodiazepínicos. Entretanto, seu efeito sobre esses receptores é menos consistente do que os benzodiazepínicos (Enoch, 2008). 
O uso crônico de álcool, estimulando continuamente os receptores GABA, produz uma inibição cerebral difusa. Na dependência, com a exposição persistente ao álcool, ocorre uma redução funcional dos receptores GABA. Esse fenômeno ocasiona a necessidade de aumento do volume ingerido de álcool para obtenção dos mesmos efeitos, fenômeno conhecido como tolerância (Volpicelli e Teitelbaum, 2010).

O sistema opióide endógeno, particularmente através das suas interações com o córtex dopaminérgico mesolímbico, esta envolvido na expressão de reforço do álcool. Os receptores opióides também apresentam interação com outros neurotransmissores, incluindo os do glutamato, GABA, serotoninérgicos (5-HT), canabinóides e sistema das glicinas, que contribuem para os seus efeitos sobre o consumo do etanol.

O álcool tem complexas interações neurobiológicas, que afetam a produção, secreção e ligação dos opioides com seus receptores. Essa relação, no entanto, permanece mal compreendida. Por exemplo, os animais acostumados a consumir etanol, apresentam uma liberação exagerada de beta-endorfina após a ingestão de etanol. No entanto, a capacidade de antagonistas opioides (naltrexona) de suprimir aumentos de beta-endorfina, associadas ao consumo de etanol, parece ser mais eficiente em animais não acostumados a consumir bebidas à base de álcool (Johnson, 2008).

A serotonina (5-HT) tem sido implicada no alcoolismo. A menor liberação dessa monoamina está associada ao maior risco de abuso do álcool. A ingestão de etanol promove a liberação de $5-\mathrm{HT}$, via estímulo dopaminérgico; por outro lado, a serotonina, através do receptor 5-HT3, parece modular a liberação dopaminergica, aumentando o estímulo da recompensa, quando ocorre o consumo do etanol. Em modelos animais, a atuação sobre esta via serotoninérgica diminui a procura pelo álcool (Heilig e Egli, 2006).

O uso crônico do álcool promove a redução funcional dos receptores GABA, provocando a redução da capacidade do etanol e benzodiazepínico em estimular os receptores gabaérgicos, que está associada à diminuição da densidade do RNAm (ácido ribonucleico mensageiro) desencadeado pela 
ligação do etanol e benzodiazepínicos aos receptores GABA. Não foi demonstrada a diminuição no número de receptores GABA (Edwards et al., 2011).

Com consumo persistente de álcool, a instalação do fenômeno da tolerância, com o aumento no número de receptores NMDA e diminuição funcional dos receptores GABA, estão criadas as condições neuroadaptativas dos alcoolistas. Caso ocorra a diminuição ou interrupção do consumo de álcool, cessa a inibição persistente do cérebro. A diminuição dos estímulos induzidos pelo álcool aos receptores GABA que apresentavam diminuição funcional e desinibição dos receptores NMDA, que já apresentavam "up-regulation", favorece a hiperativação cerebral responsável pela instalação da síndrome de abstinência ao álcool (Hoffman e Weinhouse, 2011).

\subsection{Aspectos clínicos}

O consumo de bebidas alcoólicas pode levar a um leque amplo de manifestações, a depender da combinação de fatores, como: a prédisposição genética, influência sociocultural, carga de exposição ao etanol (frequência e quantidade), estado nutricional, presença de comorbidades clínicas e psiquiátricas.

\subsubsection{Uso social}

A definição de uso social do álcool não é precisa, pois leva em conta o contexto cultural, diferindo, portanto, nas diversas culturas, e tendendo a variar à medida que a sociedade muda com o passar do tempo. De uma maneira geral, quando o álcool é consumido de forma diferente do que é aprovado pela cultura, ou quando dentro dos padrões aceitos culturalmente, mas com a ocorrência de prejuízo individual ou social, isso pode indicar um uso nocivo (World Health Organization, 1994). 
Como todos os abusadores e dependentes de álcool tiveram um consumo ocasional ou social, no início de sua carreira como bebedor, cabe aqui reconhecer o potencial risco do chamado consumo social. Quando a neurotransmissão cerebral é afetada, de forma que o comportamento do indivíduo passa a ser perigoso para si ou para os outros, levando a prejuízo ou angústia clinicamente significativos, considera-se que o bebedor ultrapassou o limiar do simples uso social (Thomas et al., 2003).

Para identificar o que seria um uso normal de álcool, em termos de frequência e quantidade, foram criadas diretrizes que identificam o padrão de consumo saudável de bebida alcoólica pela Organização Mundial de Saúde (OMS). Para o homem, o uso de até duas doses de álcool e para a mulher de até uma dose por dia, o consumo não pode ocorrer todos os dias da semana, ficando sem consumir o álcool ao menos dois dias na semana. Em algumas situações específicas, a OMS não recomenta uso de álcool: as mulheres gestantes ou tentando engravidar; aos motoristas, que venham a dirigir; trabalhadores que necessitem de alerta e atenção; a pessoas em tratamento medicamentoso ou com condições clínicas que possam ser influenciadas negativamente pelo álcool; aos alcoolistas em recuperação; por fim, aos menores de 18 anos de idade (World Health Organization, 1994).

\subsubsection{Intoxicação alcoólica}

É definida como a ingestão aguda de álcool etílico, provocando alterações mentais como: alteração do nível de consciência, da cognição, da percepção, da capacidade de julgamento, do afeto e do comportamento ou de funções fisiológicas. Normalmente são sinais da intoxicação: rubor facial, fala pastosa, marcha instável (andar ébrio), euforia, aumento da atividade, comportamento desordeiro, reações retardadas, julgamento prejudicado, incoordenação motora, labilidade emocional e estupor. Devido à aceitação social do uso de álcool, a intoxicação pelo etanol é a forma mais frequente 
de transtorno mental associado ao consumo da bebida etílica (Reynolds et al, 2012).

As alterações mentais e físicas ocasionadas pelo álcool, normalmente, mantêm relação direta com a concentração etílica no sangue, ou seja, com a quantidade de etanol consumida (tabela 5).

\subsubsection{Uso nocivo ou abuso do álcool}

No DSM-IIIR foi utilizado o termo abuso de álcool para definir um padrão mal adaptado de uso do etanol que indica um uso persistente ou recorrente, apesar da bebida causar problemas sociais, pessoais, psicológicos, físicos, legais ou profissionais. Os sintomas que caracterizam esse quadro não podem preencher critérios para o diagnóstico de dependência de álcool.

Os dois instrumentos diagnósticos existentes, DSM-IV (Diagnostic and Statistical Manual of Mental Disorders, 4a edição) e CID-10 (Classificação Internacional de Doenças - 10 ${ }^{\mathfrak{a}}$ edição), apresentam, como ponto comum, a impossibilidade do diagnóstico do uso abusivo de álcool em indivíduos com diagnóstico atual de dependência de álcool. Porém, esses instrumentos divergem quando há possibilidade do diagnóstico de abuso do álcool em pessoas que já tiveram o diagnóstico de dependência no passado. O CID-10 contempla a possibilidade do diagnóstico de uso nocivo de álcool nas pessoas que tiveram diagnóstico pregresso de dependência; já o DSM-IV não permite esse diagnóstico (Gigliotti e Bessa, 2004). 
Tabela 5. Correlação entre o nível de álcool sérico e as alterações mentais correspondentes à alcoolemia.

\begin{tabular}{|c|c|}
\hline Alcoolemia (G/L) & Efeitos clínicos \\
\hline 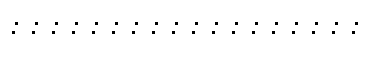 & 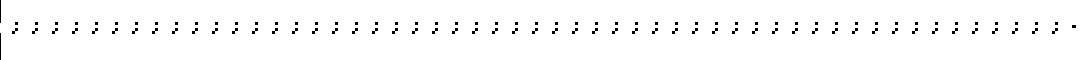 \\
\hline 0,1 a 0,3 & $\begin{array}{l}\text { Leve euforia e relaxamento; } \\
\text { Diminuição da timidez; } \\
\text { Função visual e acompanhamento de movimentos já } \\
\text { alterados. }\end{array}$ \\
\hline 0,4 a 0,6 & $\begin{array}{l}\text { Movimentos alterados; } \\
\text { Taquicardia e aumento do padrão respiratório; } \\
\text { Dificuldade de processamento de informações; } \\
\text { Tarefas de atenção prejudicadas; } \\
\text { Diminuição da inibição; } \\
\text { Relaxamento. }\end{array}$ \\
\hline 0,6 a 1 & $\begin{array}{l}\text { Aumento dos sintomas ansiosos e depressivos; } \\
\text { Diminuição da Atenção e reações mais lentas; } \\
\text { Problemas de coordenação e de força muscular; } \\
\text { Baixa capacidade de tomar decisões. }\end{array}$ \\
\hline 1 a 1,5 & $\begin{array}{l}\text { Reações ainda mais lentas; } \\
\text { Dificuldade de equilíbrio, de movimentos e de função visual; } \\
\text { Fala arrastada. }\end{array}$ \\
\hline 1,6 a 2,9 & $\begin{array}{l}\text { Diminuição de respostas a estímulos externos; } \\
\text { Problemas motores (queda e falta de coordenação motora). }\end{array}$ \\
\hline 3 a 3,9 & $\begin{array}{l}\text { Desmaios, Anestesia; } \\
\text { Estupor. }\end{array}$ \\
\hline Mais de 4 & $\begin{array}{l}\text { Dificuldades respiratórias; } \\
\text { Morte. }\end{array}$ \\
\hline
\end{tabular}

Modificada a partir de Dubowaki (1985). 


\subsubsection{Transtorno Amnésico}

O transtorno amnésico consiste em episódios transitórios de amnésia que acompanham vários graus de intoxicação. É caracterizado por amnésia retrógrada, para eventos ocorridos durante os períodos de intoxicação. Tais episódios podem estar associados com 0 beber excessivo, não necessariamente em dependentes de álcool. Teorias atuais acreditam que a base para isto seja a diminuição da serotonina e a desregulação dos receptores NMDA (Mclntosh e Chick, 2004).

\subsubsection{Intoxicação Idiossincrática}

A intoxicação patológica (intoxicação alcoólica idiossincrática) é caracterizada por um comportamento destrutivo, impulsivo, desorganizado, sem um foco ou objetivo específico, desencadeado pelo uso de pequenas doses de álcool. Normalmente é seguida de exaustão e amnésia lacunar para o episódio. O álcool pode desencadear comportamentos agressivos, mas normalmente existe concordância com níveis elevados de alcoolemia. Muitas vezes pode ser difícil diferenciá-la de distúrbio de comportamento presente após traumatismo crânio-encefálico e de quadros dissociativos (Perr, 1986).

\subsubsection{Síndrome de Dependência do Álcool}

A dependência de álcool seria um relacionamento alterado entre a pessoa e sua forma de beber, em que as razões pelas quais o indivíduo começou a beber adicionam-se àquelas relacionadas à dependência. Assim sendo, a dependência torna-se um comportamento que se retroalimenta e que abrange muito mais que tolerância e abstinência (American Psychiatric Association, 1994).

Característica comum na síndrome de dependência é a priorização do consumo da bebida alcoólica, em detrimento a outras atividades que eram 
previamente prazerosas, ocorrendo uma redução do repertório de vida do alcoolista, em consequência ao persistente consumo de bebida (Giglotti e Bessa, 2004).

Os elementos chaves na síndrome de dependência ao álcool estão expostos a seguir:

\section{a) Estreitamento de repertório.}

No início, a pessoa bebe com flexibilidade de horários, de quantidade e até de tipo de bebida. Com o tempo, passa a beber com maior frequência, até estar bebendo todos os dias, em quantidades crescentes, ampliando a frequência e desconsiderando a inadequação da situação.

Nos estágios avançados, o indivíduo consome bebida alcoólica de modo compulsivo e incontrolável para aliviar os sintomas de abstinência, sem importar-se com os danos orgânicos, sociais e psicológicos. Sua relação com a bebida torna-se rígida e inflexível.

b) Saliência do comportamento em buscar o álcool.

Com o estreitamento do repertório, há uma tentativa de o indivíduo priorizar o ato de beber, mesmo em situações inaceitáveis (no trabalho e, em situações de risco). Em outras palavras, o beber passa a ser o centro da vida, imperando sobre outros valores, como: saúde, família e trabalho.

c) Aumento da tolerância ao álcool.

Com a progressão do consumo de álcool, há necessidade de consumo de doses crescentes de etanol para obter o mesmo efeito conseguido com doses menores, anteriores, ou pela capacidade de realizar atividades apesar do consumo de elevadas doses de álcool.

d) Sintomas repetidos de abstinência.

Quando ocorre a diminuição ou interrupção do consumo de álcool, surgem sinais e sintomas de intensidade variável. No princípio, eles são leves, intermitentes e pouco incapacitantes, mas, nas fases mais avançadas, 
podem manifestar-se os sintomas mais significativos, como tremor intenso e alucinações.

e) Alívio ou evitação dos sintomas de abstinência pelo aumento do consumo de álcool.

É um sintoma importante da dependência, sendo difícil de ser identificado nas fases iniciais. Torna-se mais evidente com a progressão do quadro, como o consumo de bebida pela manhã para o paciente se sentir melhor, já que passou a noite toda sem ingerir bebida.

f) Percepção subjetiva da necessidade de beber.

Descrita como pressão psicológica ou desejo intenso de consumir bebida alcoólica e aliviar os sintomas de abstinência, também chamada de "fissura".

g) Reinstalação após abstinência.

Mesmo após longos períodos sem beber, se o alcoolista tiver uma recaída, rapidamente voltará ao padrão de consumo antigo.

O diagnóstico da síndrome de dependência de álcool é realizado a partir de critérios rígidos (CID-10), que foram elaborados pela Organização Mundial de Saúde. Existe também um segundo grupo de critérios (DSM-IV) que é concordante com o CID-10, elaborado pela Associação Americana de Psiquiatria (APA). A maior parte dos países do mundo, inclusive o Brasil, elegeu como instrumento de diagnóstico o CID-10. Ele é usado rotineiramente na prática clínica, para o indivíduo receber o diagnóstico definitivo, deve preencher mais de três, dos seis critérios (quadro 1). 

Álcool.

Quadro 1: Critérios para diagnóstico de Síndrome de Dependência de

1. Desejo persistente ou senso de compulsão para consumir o álcool.

2. Síndrome de abstinência quando diminuído ou interrompido o consumo de etanol.

3. Evidência do fenômeno de tolerância.

4. Dificuldade de controlar o comportamento de consumir o álcool em termos de início, término ou níveis de consumo.

5. Abandono progressivo de prazer ou interesses alternativos em favor do uso do álcool, aumento da quantidade de tempo necessário para obter ou tomar a substância ou para se recuperar dos efeitos da mesma.

6. Persistência do uso do álcool, a despeito da evidência clara de consequências nocivas advindas do consumo.

Elaborado a partir da Organização Mundial de Saúde (1992).

\subsubsection{Síndrome de Abstinência do Álcool}

As pessoas que bebem de forma excessiva, quando diminuem 0 consumo ou se abstêm completamente, podem apresentar um conjunto de sintomas e sinais, denominados Síndrome de Abstinência do Álcool (SAA). Alguns sintomas, como tremores, são típicos da SAA. Entretanto, muitos outros sintomas e sinais físicos e psicológicos considerados como parte da síndrome são insidiosos, pouco específicos, o que torna o seu reconhecimento e sua avaliação processos complexos.

O repertório clínico e a intensidade dos sintomas podem ser bem diferentes, a depender de fatores genéticos, constituição corporal, padrão de 
consumo, fatores socioculturais e características individuais (psicológicas e biológicas). Os sinais e sintomas mais comuns da SAA são: agitação, ansiedade, alteração do humor (disforia), tremores, náusea, vômito, taquicardia, hipertensão arterial, hipertermia leve (até $38^{\circ} \mathrm{C}$ ). Em casos graves pode ocorrer a presença de complicações como: alucinações, o delirium tremens e convulsão (Laranjeira et al., 2000).

O fenômeno de neuroadaptação é ocasionado pela exposição crônica ao álcool, "up-regulation" de receptores NMDA e redução da função de receptores GABA. Quando ocorre a diminuição ou interrupção do consumo de álcool, existe hiperatividade glutamatérgica e hipoatividade do GABA. Esse fenômeno produz um aumento de liberação de noradrenalina e redução da dopamina, condição responsável por grande número das reações fisiológicas, tais como: taquicardia (ativação de receptores betaadrenérgicos); hipertensão arterial (ativação dos receptores alfaadrenérgicos); aumento da força de contração cardíaca (ação adrenérgica inotrópica positiva); náusea e vômito (por redução do esvaziamento gástrico); tremores (por facilitação de neurotransmissão muscular); piloereção; midríase; aumento do consumo de oxigênio; também, aumento da temperatura corporal em até $2^{\circ} \mathrm{C}$ (Mclntosh e Chick, 2004).

Outras alterações presentes na SAA são: hipoatividade dopaminérgica associada ao reforço negativo e disforia; hipoatividade gabaérgica provocando ansiedade, convulsão e aumento da atividade do glutamato; hiperatividade glutamatérgica que está associada à confusão mental e alucinações e também convulsão (Maciel e Kerr-Correa, 2004).

O quadro inicia-se entre 6 e 24 horas após o a mudança no consumo do álcool. A presença de quadros graves ocorre em 10\% dos casos. Complicações como convulsão e delirium tremens ocorrem em $5 \%$ dos pacientes com SAA, não tratados. A presença dessas complicações é um indicativo de risco elevado de morte, entre 10 e $25 \%$. As convulsões podem ocorrer em qualquer momento da abstinência, mas quanto mais precoces, indicam maior gravidade (Hillemarcher et al., 2012). 
O delirium tremens caracteriza-se como estado confusional breve, que se acompanha de perturbações somáticas. Normalmente indica dependentes graves de álcool, com histórico longo de uso de álcool. Podem existir sintomas prodrômicos inespecíficos (insônia, tremores e medo), algumas vezes podem ser precedidos por crises convulsivas por abstinência. É definida pela presença da tríade: obnubilação da consciência ou confusão mental; alucinações ou ilusões vividas, afetando qualquer modalidade sensorial (são típicas alucinações visuais de pequenos animais: ratos ou baratas); tremores marcantes. Ocorrem entre o primeiro e o terceiro dia de abstinência, duração média de 10 a 12 dias, podendo se estender de uma semana a dois meses (Laranjeira et al., 2000).

\subsubsection{Alucinose Alcoólica}

Sintomas psicóticos como as alucinações (alucinose alcoólica) ou ideias delirantes podem estar presentes em dependentes de álcool. As ideias delirantes são frequentemente de conteúdo persecutório e pouco estruturadas. As alucinações normalmente são auditivas ou visuais, habitualmente vívidas, e ocorrem na ausência de rebaixamento do nível de consciência. A alucinose alcoólica em geral se inicia após períodos de redução ou cessação do consumo do álcool, tem curta duração, apesar de poder haver cronificação, quando os sintomas estão presentes por mais de 6 meses, produzindo quadro semelhante à esquizofrenia (Bayard et al., 2004).

\subsubsection{Encefalopatia de Wernicke}

Carl Wernicke que em 1881 descreveu, pela primeira vez, uma patologia com início súbito, caracterizada por paralisia dos movimentos oculares, marcha atáxica e confusão mental - observou que os portadores desse quadro eram frequentemente alcoolistas, mas estes não eram os únicos a apresentar o quadro. O quadro posteriormente chamado de 
"Síndrome de Wernicke" estava presente em estados nutricionais deficitário, como na deficiência de vitaminas do complexo $B$, particularmente tiamina (vitamina B1), um cofator importante na utilização de glicose (Zubaran et al., 1996).

A tríade clássica descrita por Wernicke é composta por confusão mental, ataxia cerebelar e alterações oculares (oftalmoplegia bilateral e nistagmo, principalmente). Pode ocorrer a forma incompleta, ou estar associada a outras manifestações neurológicas. Trata-se de um quadro agudo, que pode ser desencadeado pela administração de glicose, previamente à de tiamina, em indivíduos com deficiência nutricional (FidalgoNavarro et al., 2012).

Distúrbios de consciência e do estado mental ocorrem em 10\% dos pacientes e manifestam-se como um estado confusional global, no qual o paciente está apático, desatento e com mínima expressão verbal. Sintomas de abstinência ao álcool, como alucinações, agitação, alteração da percepção e hiperatividade autonômica podem estar presentes, com menor frequência.

Ocorre por lesões hemorrágicas agudas na substância cinzenta e em corpos mamilares, no terceiro e quarto ventrículos e aqueduto. Com a instituição da terapêutica adequada (reposição de tiamina por via parenteral), ocorre a remissão completa dos sintomas, mas, do contrário, há risco de evolução para a forma crônica, conhecida com demência de Korsakoff (Charness, 2010).

\subsubsection{Síndrome de Korsakoff}

Magnus Huss, em 1885, fez menção a um distúrbio de memória em alcoolistas. Entre 1887 e 1891 o psiquiatra russo Sergei Sergeievich Korsakoff relacionou a desordem da memória à patologia descrita por Wernicke, afirmando que seriam "duas faces da mesma doença". A Psicose ou Síndrome de Korsakoff foi postulada como decorrente da doença de Wernicke em 1897 por Murawieff (Vein, 2009). 
O estado amnésico característico da síndrome de Korsakoff é marcado por uma lacuna permanente na memória do paciente. O principal aspecto da desordem da memória é o defeito do aprendizado (amnésia anterógrada) e perda da memória passada (memória retrógada) A memória imediata está intacta, mas a memória de curto prazo está comprometida. O defeito do aprendizado é que leva a incapacitação do alcoolista para a sociedade, ficando apto apenas para tarefas simples e habituais. A memória de longo prazo parece ser mantida através de rede neural multifocal, mais do que pontos anatômicos específicos, uma vez que pacientes com quadros graves de psicose de Korsakoff podem ter memória excelente (Zubaran et al., 1996).

A confabulação é um achado característico desta patologia. Nas fases iniciais, caracterizadas por quadro de confusão mental grave, a confabulação é evidente e significativa. $\mathrm{Na}$ fase convalescente o paciente tem lembranças fragmentadas da experiência da fase aguda, produzindo uma distorção na memória. Os pacientes normalmente não percebem sua condição. $\mathrm{O}$ achado de atrofia de corpos mamilares é um sinal relativamente especifico da síndrome de Korsakoff. Os portadores dessa moléstia raramente se recuperam, normalmente necessitam de supervisão e apoio social (Kessels e Kopelman, 2012).

\subsubsection{Síndrome Demencial}

A síndrome demencial alcoólica é semelhante à demência propriamente dita, como a de Alzheimer. Acomete dependentes de álcool com histórico de uso prolongado de bebida e com problemas nutricionais. Essa forma de demência pode ocorrer mesmo sem a síndrome de Wernick-Korsakoff. $\mathrm{O}$ álcool pode provocar lesões difusas no cérebro, prejudicando além da memória, a capacidade de julgamento e planejamento, de abstração de conceitos. A personalidade pode se alterar, o comportamento como um todo fica prejudicado (Marsui et al., 2012). 
Normalmente, estão presentes complicações clínicas como: pelagra, anemia, insuficiência pancreática e hepática, que também decorrem do uso persistente do etanol e de subnutrição. A pessoa torna-se incapaz de sustentar-se (Charness, 2010).

\subsubsection{Tipologia para alcoolistas}

Em algumas doenças crônicas como diabetes, câncer, asma e hipertensão arterial, assim como no alcoolismo, têm sido crescentes o interesse dos pesquisadores em desenvolver tipologias, que visam não apenas nomear e classificar, mas também, desenvolver teorias etiológicas para os diferentes subgrupos e ajudar o desenvolvimento de estratégias preventivas e terapêuticas mais eficazes (Ribeiro et al., 2008).

Varias tipologias para alcoolistas foram desenvolvidas ao longo do século XX. São exemplos destas: Knight; Menninger, Jellinek; Conley e Prioleau; Von Knorring; Morey e Skinner; Zucker; Cloninger; Babor; Mezzich; Johnson e Pickens. Contudo, as tipologias, que têm despertado maior interesse cientifico, são as tipologias de Cloninger, Babor e Lesch (Ribeiro et al, 2009).

A tipologia desenvolvida por Cloninger, a partir do Stockholm Adoption Study (SAS), para avaliar a contribuição de fatores genéticos e ambientais no alcoolismo, identificou dois tipos de alcoolistas, nomeados Tipo 1/Tipo 2, entre os 862 homens suecos envolvidos no estudo (Cloninger et al., 1981). Pesquisadores indicaram que os subtipos identificados não representariam entidades nosológicas distintas, mas sim, antes de tudo, os dois extremos de um espectro contínuo de manifestações clínicas do uso disfuncional de álcool, de cada indivíduo (Cloninger et al., 1996).

a) Os integrantes do subtipo denominado "Tipo 1" se caracterizam por abuso leve, com rápida progressão para abuso intenso e início tardio de problemas relacionados ao álcool. Mais frequentemente desenvolvem complicações médicas e manifestam sentimentos de culpa e medo com relação à dependência ao álcool. Em relação aos 
traços de personalidade, apresentam menores taxas de busca de novidade e mais elevada de comportamentos de evitação de danos, de busca de gratificação, ansiedade cognitiva e consumo para alívio de ansiedade; impulsividade e traços de personalidade antissocial não são frequentes. A existência de alcoolismo familiar tem menos peso neste subgrupo e o ambiente contribuiu de forma importante para o abuso/dependência de álcool.

b) O "Tipo 2" caracterizou-se por abuso moderado e início precoce dos problemas relacionados ao álcool. Eles têm maior dificuldade para abster-se do consumo e se envolvem mais em brigas e prisões. Quanto aos traços de personalidade, estes tendem a buscar mais as novidades, a serem mais impulsivos, a apresentarem ansiedade somática e características antissociais. Neste subtipo, a indução de euforia é uma grande motivação para beber. Os fatores genéticos têm papel mais relevante que os ambientais. Alguns dos problemas desta tipologia estão na dificuldade de aplicação clínica das 16 variáveis necessárias para identificação dos alcoolistas; ainda a distinção entre a influência ambiental e genética para $o$ desenvolvimento do alcoolismo é por vezes complicada (Sigvardsson et al., 1996).

Lesch et al. (1988) em estudo prospectivo durante 18 anos, acompanhando 444 dependentes de álcool, observando características da personalidade, padrão de uso do álcool, história familiar, dados clínicos e sociais destes alcoolistas, propuseram uma classificação com quatro tipos de alcoolistas, com estratégias de tratamento distintas para cada tipo.

a) Tipo I é caracterizado por síndrome de abstinência grave (acompanhado às vezes de convulsão), que tipicamente inicia o consumo de álcool de modo social progredindo para consumo constante. Ele está bem adaptado socialmente, mantém atividades de lazer, bom convívio social e familiar. Normalmente não apresenta 
história de distúrbios na infância ou envolvimento em crimes. O foco do tratamento neste grupo deve ser a abstinência.

b) O tipo II pode ser confundido com o bebedor social, não apresenta comprometimento somático. Ele apresenta aparente beber controlado, tem bom convívio social e menos atividades de lazer. Tipicamente sofre com o domínio materno, tem comportamento passivo e, quando alcoolizado, muda o seu comportamento. $O$ álcool tem o papel de tratar sua ansiedade, chegando a ser consumida com outras drogas sedativas. Este tipo se beneficia também de psicoterapia e terapias alternativas.

c) O tipo III apresenta graves danos sociais e, tipicamente, apresenta comprometimento psiquiátrico. Normalmente bebe sozinho, têm problemas sociais e familiares graves, histórico de agressões a pessoas próximas (com e sem álcool), crimes relacionados ao álcool e desemprego frequentes. Apresenta tendência autodestrutiva e pensamentos suicidas. Tem história pessoal e familiar de doença psiquiátrica, o álcool é consumido como automedicação, apresentando pouco tempo de abstinência. O tratamento deve-se basear na comorbidade psiquiátrica diagnosticada.

d) O tipo IV apresenta dano cerebral neonatal ou até os 14 anos de idade, com complicações somáticas importantes (deterioração cerebral, epilepsia ou polineuropatia), decorrentes de hipóxia periparto, meningites e traumas. Histórico pessoal de enurese noturna, gagueira e dificuldade social estão presentes. Apresentam graves sinais de intoxicação alcoólica, mesmo com baixas doses de álcool. Evidências de anormalidades psiquiátricas, somáticas e sociais não estão limitadas ao período de consumo de álcool. Para este grupo terapias de neurorreabilitação devem ser desenvolvidas (Zago-Gomes e Nakamura-Palacios, 2009; Lesch et al., 1996; Lesch et al, 1990). 
Em 1992 Babor et al. propuseram, após acompanharem 321 alcoolistas, uma tipologia pautada na análise de 17 variáveis destes pacientes, que podem ser agrupadas em quatro características: risco prémórbido e vulnerabilidade; gravidade da dependência; gravidade dos problemas com o álcool, psicopatologia associada. Os dois tipos identificados estão citados abaixo:

a) Tipo A caracteriza-se por alcoolistas de início tardio, evolução lenta, menor frequência de fatores de risco na infância, menor influência genética, menor frequência de psicopatologia associada e melhor prognóstico.

b) Tipo B caracteriza-se pelo início do consumo do álcool precoce, maior frequência de alcoolismo familiar, maior gravidade de dependência, frequente dependência de outras substâncias, maior comorbidade de psicopatologia associada, maior frequência de fatores de risco familiar e pior prognóstico.

Existe grande discussão acerca da natureza e do número de subtipos que devem ser usados para caracterizar a heterogeneidade clínica e etiológica presentes nesses grupos de alcoolistas. Contudo, existe uma tendência à identificação de dois tipos básicos de alcoolistas. Um tipo seria caracterizado pelo início tardio do consumo de álcool, evolução mais lenta, menos complicações, menor comorbidade psicopatológica e melhor prognóstico. O outro tipo apresentaria predisposição genética, início precoce do consumo de álcool, evolução mais rápida para dependência, mais comorbidade psicopatológica, sintomas mais graves de dependência e pior prognóstico (Babor et al, 2006; Ribeiro et al, 2002).

\subsection{Tratamento}

A dependência de álcool é um transtorno médico crônico caracterizado por recaídas frequentes. Apesar das implicações sociais e 
psicológicas, uma vez estabelecida, a dependência do álcool tem que ser vista como um distúrbio cerebral que se assemelha a outras desordens crônicas recorrentes, como o diabetes e a hipertensão. De fato, um tratamento baseado exclusivamente em medidas psicossociais, sem uso de terapia medicamentosa, está associado a resultados clínicos insatisfatórios, com o retorno ao uso de álcool em $70 \%$ dos pacientes no período de um ano de tratamento (Finney et al., 1996).

O tratamento médico do alcoolismo ocorre, inicialmente, em regime ambulatorial ou, em casos específicos, em regime de internação, que pode acontecer em leitos de hospital geral ou psiquiátrico. Os grupos de mútua ajuda (para o dependente ou para sua família), entidades religiosas e comunidades terapêuticas mostram-se também como opções terapêuticas para casos específicos.

Os alcoolistas têm mudanças em seu comportamento frente ao consumo de álcool durante vários estágios de suas vidas. Em 1982, a partir da observação de dependentes de nicotina, foi desenvolvido um modelo dos estágios de mudança desses frente ao consumo de substância da qual são dependentes. Esse modelo postula que os pacientes passam por cinco estágios para conseguir a abstinência (tabela 6). Caso o paciente apresente uma recaída, no uso da substância, passaria novamente por todos os estágios (Diclemente e Prochaska, 1982; Pelc, 1997).

Como em todas as doenças crônicas com recaídas frequentes, o alcoolismo, necessita de abordagem multidimensional, utilizando abordagens psicossociais, comportamentais e psicofarmacológicas. Até o momento estão aprovados apenas três medicamentos para o tratamento de alcoolista pelo FDA (Food and Drug Administration, órgão do governo americano responsável pela autorização do uso de medicamentos nos EUA), a saber: o dissulfiram, acamprosato e naltrexona. Desta forma 0 desenvolvimento de novas possibilidades farmacológicas no tratamento de alcoolismo tem se tornado uma área de interesse crescente entre pesquisadores sobre o alcoolismo (Baltieri et al., 2008; Brower et al., 2008; Johnson et al., 2000a). 
Tabela 6. Fases dos dependentes de álcool frente ao tratamento.

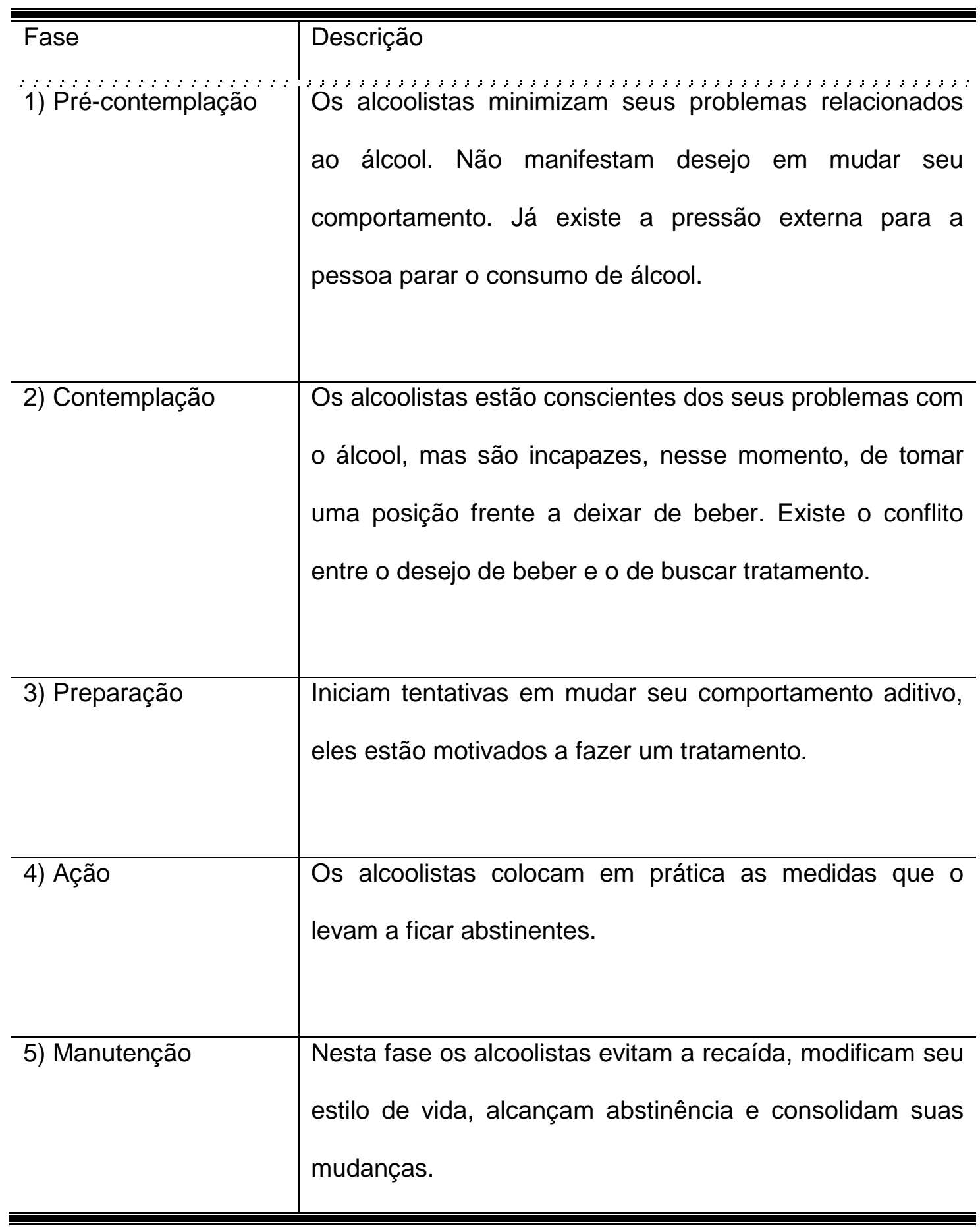

Produzido a partir do modelo de DiClemente e Prochaska (1982). 


\subsubsection{Aspectos gerais do tratamento}

A dependência de álcool é percebida como um transtorno crônico de natureza multidimensional. $O$ tratamento deve contar com abordagens diversificadas, capazes de atender às múltiplas demandas das pessoas acometidas por esse transtorno. Apesar de existirem algumas controvérsias no tratamento, entre essas qual a melhor combinação das abordagens terapêuticas, não existe dúvida de que a associação delas é melhor que um tratamento isolado. (Kahn, 1990). A combinação dessas abordagens facilita a adesão do paciente aos programas de tratamento, aumenta as chances de abstinência e de os pacientes completarem o tratamento (Oslin et al., 2008; Pettinati et al., 2005).

\subsubsection{Abordagens não farmacológicas}

Das modalidades de psicoterapias usadas para alcoolismo a psicanálise, apesar de ser amplamente usada, tem pouca evidência científica que confirme sua efetividade. Atualmente, as abordagens mais eficazes utilizadas são intervenções de caráter cognitivo-comportamental, terapia familiar e de casal, treinamento das habilidades sociais, entrevista motivacional, contrato terapêutico e intervenções breves (Carroll, 2005; Marques, 2001).

\subsubsection{Terapia cognitivo-comportamental}

As intervenções puramentes cognitivas, sem um componente comportamental, têm resultados desanimadores. Por outro lado, existem abundantes evidências de que as abordagens de Terapia cognitivocomportamental (TCC) dirigidas ao aumento do autocontrole e das habilidades sociais dos dependentes levam à diminuição do consumo de bebida (Miller e Wilbourne, 2002). As técnicas cognitivo-comportamentais são usadas para melhorar o autocontrole. Essas terapias baseiam-se em 
dois pontos centrais: as habilidades cognitivas e comportamentais têm papel central no desenvolvimento e manutenção do alcoolismo; as abordagens cognitivo-comportamentais empregam algum grau de treinamento de habilidades de enfrentamento, para lidar com as dificuldades cognitivas e comportamentais apresentadas por esses dependentes (Morgenstern e Longabaugh, 2000).

A TCC tem por objetivo desenvolver o autocontrole por meio da substituição de comportamentos disfuncionais por funcionais. Isto ocorre por técnicas que focam no automonitoramento, fixação de objetivos, gratificação pela realização de metas, análise funcional das situações de ingestão de bebidas alcoólicas e aprendizado de habilidades de enfrentamento alternativas (Liese e Franz, 2005).

\subsubsection{Intervenções breves}

As intervenções breves variam em relação ao conteúdo trabalhado e ao tempo de duração, podendo tanto ser disponibilizadas em poucos minutos, quanto em alguns encontros. O conteúdo e tempo não uniforme dessas intervenções produzem uma modalidade terapêutica muito heterogênea, que prejudica a análise dos seus resultados. Moyer et al. (2002) agruparam essa modalidade em dois grupos básicos: o primeiro com intervenções de curta duração, feitas em serviços básicos de saúde, voltado para pacientes não graves relacionados ao consumo de álcool e com baixa motivação para o tratamento; o segundo grupo usadas em centros especializados, muitas vezes usados como grupo controle, normalmente mais longos, estruturados e realizados por especialistas.

Os principais objetivos das intervenções breves são estimular 0 reconhecimento de problemas, o compromisso com a mudança, a redução do consumo de álcool e um breve treinamento de habilidades (Brown, 2001).

Em 1995, Miller e Wilbourne publicaram uma revisão sobre as psicoterapias. Eles apontaram que as intervenções breves foram as que obtiveram maior pontuação entre as abordagens capazes de promover 
algum efeito benéfico sobre a redução do consumo de álcool. Contudo uma grande crítica foi feita a esta conclusão, pois a população que recebeu intervenção breve foi de pessoas com problemas com o consumo de álcool, mas não necessariamente dependentes dessa substância. Outro ponto em discussão nessa intervenção é o tempo de duração mais adequado (Moyer et al., 2002).

\subsubsection{Treinamento de habilidades sociais}

Essa abordagem constitui-se no treinamento de habilidades de enfrentamento, usando enfoque cognitivo-comportamental. Ela destina-se a auxiliar o paciente a lidar com situações associadas ao risco de consumo de álcool, por meio de habilidades específicas a determinadas situações, ou a partir de habilidades sociais gerais. O foco central, portanto, não é o consumo de álcool em si, mas os problemas relacionados a outras áreas da vida, frequentemente associadas ao comportamento de beber. São focos desse treinamento: assertividade, a recusa de situações em geral ou correlatas ao uso de bebida, habilidades para receber ou fazer criticas, habilidades para escutar, para conversar e resolver conflitos interpessoais, além de aspectos relacionados à comunicação não verbal e à expressão de sentimentos (Bonadio e Figlie, 2007; Monti e Rohsenow, 1999).

O treinamento de habilidades tem sido amplamente estudado em ensaios clínicos controlados, sendo os resultados significativamente favoráveis à sua eficácia, quando utilizado como abordagem central ou em conjunto com outros enfoques (Morgenstern e Longabaugh, 2000; Mille e Wilbourne, 1995).

\subsubsection{Abordagem de fortalecimento comunitário}

Trata-se de abordagem é individual e intensiva, com duração de 5 a 8 sessões. A essência desse método é o reforço positivo de comportamentos 
promotores de abstinência. Em outras palavras, a abordagem foca na mudança de estilo de vida e rearranjo do ambiente social, mudando o reforço positivo associado a beber para outras atividades não relacionadas ao consumo de substâncias.

Componentes de diversas abordagens comportamentais são usadas no fortalecimento comunitário, entre elas o contrato terapêutico, treinamento de habilidades sociais, o aconselhamento motivacional e o manejo de humor. Alguns pesquisadores têm verificado a eficácia dessa abordagem (Miller e Wilbourne, 2002; Brown, 2001; Miller et al, 1999).

\subsubsection{Entrevista motivacional}

Miller et al. (2003) desenvolveram a entrevista motivacional com o objetivo de auxiliar os alcoolistas na resolução da ambivalência, relacionada aos comportamentos ligados ao consumo da bebida. Essa abordagem é de fácil aplicação e de baixo custo, podendo ser desenvolvida em sessão única ou em quatro a seis sessões. Ela tem como base princípios cognitivos como entendimento dos problemas e reações emocionais frente a eles, estabelecimento de alternativas para modificação em padrões de pensamentos e implementação de soluções (Bundy, 2004).

A entrevista motivacional é baseada em dois princípios. O primeiro é a ambivalência, que é um grande obstáculo no processo de mudança dos alcoolistas. O outro princípio é o modelo de mudança de comportamento dos alcoolistas frente ao consumo de álcool (pré-contemplação, contemplação, preparação, ação, manutenção e recaída). Estes estágios refletem níveis de motivação nos quais os dependentes estão para mudar seu comportamento frente ao consumo do álcool (Diclemente e Prochaska, 1982; Davidson et al., 1997). Miller et al. (2003) descreveram cinco posturas que norteiam as técnicas da entrevista motivacional, citadas abaixo:

a) Expressar empatia; 
b) Desenvolver discrepância entre as metas e os comportamentos desenvolvidos;

c) Evitar a confrontação para não aumentar a resistência;

d) Aceitar a resistência para trabalhá-la;

e) Estimular a autoeficácia.

Alguns pontos são considerados chaves nessa entrevista não podendo ser esquecidos durante o processo de mudança. Para tanto, Bien et al. (1993) recomendam o acrômio inglês FRAMES: devolutiva (feedback), responsabilidade (responsibility), aconselhamento (advice), alternativas (menu), empatia (empathy) e autoeficácia (self-efficacy).

\subsubsection{Prevenção de recaída}

A prevenção de recaída foi descrita por Marlatt e Gordon (1994) como um programa de automanejo que visa aprimorar a mudança de hábitos iniciada com a abstinência. A dependência de substância é vista como o resultado de um mau hábito adquirido e passível de mudança, com a partipação do paciente.

O foco desta abordagem é a manutenção da abstinência, usando técnica de mapeamento de situações de risco para o consumo do álcool. Não seria apenas a identificação de locais físicos a serem evitados, mas também estressores ambientais e fatores emocionais que estão associados a risco elevado de recaída. As situações de elevado risco para o consumo das drogas podem provocar dois tipos de respostas: enfrentamento (ações que permitem aumentar a capacidade do alcoolista em manter sua abstinência, aumentando a autoeficácia) e não enfrentamento (falta de resposta à situação de risco que leva a uma diminuição da autoeficácia, que aliada a um comportamento disfuncional expõe ao uso e aumenta a probabilidade de recaída). O uso de abordagens cognitivo-comportamentais, 
como treinamento de habilidades, é um importante aliado para a prevenção de recaída (Monti et al., 1995).

O uso da abordagem de prevenção de recaída é de baixo custo e de fácil aplicação. Os estudos clínicos têm mostrado que o grupo que mais se beneficia são os alcoolistas de moderada a grave intensidade e ainda com elevado grau de angústia (Dimeff e Marlatt, 1995).

\subsubsection{Contrato terapêutico}

A realização de um contrato de comportamento, verbal ou por escrito, com o paciente é uma maneira de responsabilizá-lo ativamente no seu processo terapêutico. Baseia-se no princípio do condicionamento operante; ainda, estabele-se uma relação contigêncial entre certas metas do tratamento e o reforço desejado. Ele serve para clarificar os objetivos do tratamento e mostrar o percurso para alcançar estas metas (Brown, 2001).

Ao iniciar o tratamento o paciente deve ser informado das etapas terapêuticas, do funcionamento dos atendimentos, do papel esperado dele durante 0 tratamento $\mathrm{e}$, após o estabelecimento dos objetivos com 0 alcoolista, do caminho necessário para alcançar as metas determinadas, assim como informá-lo de possíveis situações de risco que podem surgir.

O contrato terapêutico tem sua eficácia comprovada em ensaios clínicos, que tem ele como enfoque central, ou associado a outras abordagens (Miller e Wilbourne, 2002; National Institute on Alcohol and Alcoholism, 2000).

\subsubsection{Alcoólicos Anônimos}

Os alcoólicos anônimos (AA) foram criados por Bob Smith e William Wilson em 1935, na cidade de Akron (Ohio - Estados Unidos da América), com o propósito de manter os envolvidos sóbrios e ajudar outros membros a 
alcançar a sobriedade. Com a criação do programa de 12 passos o AA ganhou impulsão e rapidamente se expandiu pelo mundo, hoje estando presente em praticamente todas as cidades do mundo (Gross, 2010).

Os grupos do AA seguem a mesma versão dos 12 passos, os participantes desse grupo se reúnem regularmente para discutir seus problemas, compartilhar suas vitórias e receberem o apoio mútuo. Entre as características mais conhecidas do programa está à apresentação pelo primeiro nome e o exercício de admitir que tem um problema frente ao álcool. Os 12 passos que norteiam esse grupo de mútua ajuda estão citados a baixo (Galanter et al., 2007):

a) Admitir que são impotentes perante o álcool - tendo por períodos de domínio do álcool sobre a sua vida.

b) Acreditar que um poder superior pode lhes devolver a sanidade.

c) Entregar a vontade e a vida aos cuidados de Deus, na forma em que o conhecem.

d) Realizar minucioso e destemido inventário moral deles mesmos.

e) Admitir perante Deus, a si mesmo e a outro ser humano a natureza exata da sua falha.

f) Prontificar-se inteiramente a deixar que Deus remova todos esses defeitos.

g) Rogar humildemente a Deus para que ele os livre das imperfeições.

h) Fazer uma relação de todas as pessoas que foram prejudicadas e se dispor a reparar os danos causados.

i) Fazer reparação direta aos danos causados a outrem, sempre que possível, salvo quando fazê-lo signifique prejudicar terceiros.

j) Fazer continuamente o inventário pessoal e, quando estiver errado, prontamente admitir.

k) Procurar, através da prece e da meditação, melhorar o contato consciente com Deus, na forma que é concebido, rogar apenas o conhecimento de sua vontade, e forças para realizar essa vontade. 
I) Tendo experimentado um despertar espiritual, graças a estes passos, procurar transmitir essa mensagem aos alcoólicos e praticar esses princípios durante todas as suas atividades.

A efetividade do $A A$ em si não está clara. Existem alguns indícios crescentes a favor da utilidade desse grupo de mútua ajuda. Alguns estudos mostram que maior participação nesse grupo está associada a maiores taxas de abstinência e menor consumo de bebidas alcoólicas (Magura et al., 2013; Krentzman, et al., 2010; American Psychiatric Association, 2006).

\subsubsection{Tratamento farmacológico}

O tratamento farmacológico para dependência de álcool possui três eixos básicos, a saber, intoxicação, síndrome de abstinência ao álcool e promoção de abstinência. Os dois primeiros já estão bem sedimentados e a importância da medicação, bem como o papel de cada medicamento, segue diretriz específica. $O$ tratamento farmacológico em longo prazo do alcoolismo tem como principais objetivos, em combinação com medidas não farmacológicas, a abstinência (ou redução no uso e nos efeitos), prevenção de recaída e reabilitação (American Psychiatric Association, 2006).

\subsubsection{Naltrexona}

A naltrexona é um antagonista do receptor opioide desenvolvido para tratamento de dependência de opioide, mas também usado principalmente para o tratamento de alcoolistas. A partir da publicação dos primeiros estudos com esse antagonista opioide, em 1992, tem-se demonstrado sua eficácia em reduzir a frequência e a gravidade das recaídas no consumo do álcool. Vários ensaios clínicos feitos ratificam este efeito. A aprovação pelo FDA para o tratamento de alcoolistas ocorreu em 1994 (Anton et al., 2006; Latt et al., 2002). 
A ação do naltrexona no tratamento dos dependentes de álcool acontece principalmente pelo antagonismo opioide. Apesar de existir alguma afinidade para o receptor kapa-opioide, o seu principal efeito farmacológico sobre o consumo de álcool ocorre através do bloqueio do receptor muopioide. A ingestão de álcool aumenta a liberação de beta-endorfina em regiões específicas do cérebro, como o nucleus accumbens, efeito bloqueado pela naltrexona. Os opioides podem servir como neuromoduladores, facilitando a liberação dopaminérgica no nucleus accumbens ou estimulando a neurotransmissão gabaérgica na área tegmental ventral (Johnson et al., 2000a).

Clinicamente a naltrexona tem dois efeitos principais que levam à redução do consumo de álcool: primeiro, reduzindo a "fissura" pela bebida, ação que persiste enquanto o paciente estiver usando a medicação; um segundo efeito ocorre quando o uso do antagonista opioide, bloqueando o reforço positivo obtido com o consumo do álcool, está associado com o uso controlado de bebida alcoólica. Essa associação provoca uma redução progressiva da "fissura" pelo álcool ao longo do tempo, efeito esse que tende a persistir apesar da interrupção do uso da naltrexona, mas não com o retorno do consumo abusivo do etanol (Parkes e Sinclair, 2000).

A naltrexona apresenta rápido início de ação (com pico em uma hora) e elevada taxa de absorção (96\%). Apresenta $21 \%$ da medicação circulante ligada a proteínas plasmáticas. A meia vida dele é de $24 \mathrm{~h}$, apresenta excreção predominante renal. Efeitos colaterais, quando presentes, ocorrem no início do tratamento e são pouco intensos. Os principais são a náusea, cefaleia, tontura e elevação das enzimas hepáticas. Além da esperada interação com analgésicos opioides, o antagonista não apresenta outras interações significantes (Castro e Baltieri, 2004). A posologia padronizada para tratamento é um comprimido, de $50 \mathrm{mg}$, uma vez ao dia, pelo período de 12 semanas. Nos EUA, além da apresentação para uso via oral, existe solução injetável de naltrexona com liberação lenta, medicação de depósito, que pode ser aplicada mensalmente. 


\subsubsection{Acamprosato}

O acamprosato, também conhecido como acetil-homotaurinato de cálcio, que vem sendo utilizado para tratamento de alcoolistas há mais de duas décadas, foi aprovado para o uso na Europa em 1989 e somente em julho de 2004 teve sua aprovação pelo FDA (Mann et al., 2008).

O acamprosato é absorvido lentamente pelo trato gastrointestinal (menos de $10 \%$ da medicação chega a ser absorvida) e a presença de alimentação reduz a absorção deste fármaco. A meia vida é de 1 a 3 horas, alcançando estado de equilíbrio em 5 a 7 dias de uso. Faz pouca ligação com proteínas e apresenta excreção predominantemente renal (90\%), sendo contraindicado em pacientes com insuficiência renal. Os efeitos colaterais mais frequentes são diarreia e prurido, podendo apresentar menos frequentemente, dores abdominais, eritema maculo-papular, náuseas e vômitos (Wilde e Wagstaff, 1997).

Foi desenvolvido para tentar equilibrar as alterações desencadeadas pela síndrome de abstinência em usuários crônicos do álcool, a saber, hipoatividade do sistema GABA e hiperatividade glutamatérgica. $O$ acamprosato atravessa a barreira hematoencefálica melhorando a recaptação do GABA no tálamo e hipotálamo. Essa medicação possui ação como co-agonista parcial do NMDA, ainda, atuaria reduzindo a recaptação de cálcio induzida pelo glutamato nos neurônios, suprimindo a resposta condicionada em dependentes (Scott et al., 2005).

A posologia do acamprosato é determinada pelo peso do paciente: se menor que $60 \mathrm{Kg}$, prescrevem-se 2 comprimidos com 333mg de acetilhomotaurinato de cálcio cedo e 1 comprimido à tarde e à noite (no total de quatro comprimidos); se o peso for maior que $60 \mathrm{Kg}$, usa-se o total de seis comprimidos em três vezes ao dia (dois comprimidos pela manhã, tarde e noite). Essa medicação deve ser usada sempre antes das refeições (Mason, 2005; Baltieri e De Andrade, 2004). 


\subsubsection{Dissulfiram}

O dissulfiram é utilizado como medicamento para tratamento de alcoolismo há mais de 60 anos. Foi o primeiro medicamento aprovado pelo FDA para essa finalidade, em 1951. Foi desenvolvido como antiparasitário, entretanto, quando foi testado, as pessoas que usaram a medicação relataram grande mal-estar, quando ingeriam bebida alcoólica (Jorgensen et al.. 2011).

Esse fármaco é rapidamente absorvido pelo trato gastrointestinal (70 a 90\%), tem característica lipofílica, acumula-se no tecido adiposo do fígado, rins e músculos. A excreção é renal, sendo que $80 \%$ é lentamente eliminada durante vários dias (Cordioli, 2011).

Durante o metabolismo, o álcool é convertido em acetaldeído pela enzima álcool-desidrogenase. Por ação de outra enzima, acetaldeídodesidrogenase, o acetaldeído (uma substância tóxica para o organismo) é convertido em acetato. O dissulfiram atua como inibidor irreversível e inespecífico da enzima acetaldeído-desidronase, ocasionando aumento de acetaldeído em 5 a 10 vezes do normal, provocando o efeito antabuse (Petersen, 1992).

A reação etanol-dissulfiram, conhecida também como efeito antabuse, inicia-se 5 a 10 minutos após o consumo do álcool e pode durar de 30 minutos a horas. O quadro clínico inclui rubor facial, taquicardia, falta de ar, náusea, vômitos, cefaleia pulsátil, distúrbios visuais, confusão mental, síncope postural e colapso circulatório (Quinn et al., 1997).

O dissulfiram é uma medicação com boa tolerância. A hepatite pode ocorrer, mas é um efeito colateral raro, que pode acontecer no segundo mês de tratamento. O cuidado com o uso desta medicação deve existir em pessoas com transtorno mental grave, que tenham prejudicadas a sua capacidade de compreender os cuidados com o uso desse fármaco. Essa medicação é contraindicada em cirróticos com hipertensão portal, devido aos vômitos da reação antabuse poderem provocar hemorragia digestiva alta.

A dose recomendável para promover abstinência é 250mg por dia, podendo ser aumentada para 500mg por dia. Existem evidências de que 
pacientes suportam uso por um ano. O antietanol é prescrito continuamente, mas pode ser usado por demanda, durante períodos de maior risco (Castro e Baltieri, 2004). O uso da medicação deve respeitar certas condições. Para início do uso da medicação, deve-se respeitar o intervalo de 12 horas sem beber.

\subsubsection{Topiramato}

O topiramato é uma medicação anticonvulsivante, que tem despertado o interesse crescente de pesquisadores para o tratamento de dependentes de álcool. O efeito anticonvulsivante acontece pela sua ação, estimulando a neurotransmissão do sistema GABA, via receptores não benzodiazepínicos, e pela redução da ação excitatória glutamatérgica, através de sua ação como antagonista de receptor tipo AMPA/Kainato (Baltieri et al., 2008; Cordioli, 2011).

Até o presente momento, o topiramato foi aprovado pelo FDA para o tratamento de Epilepsia, Síndrome de Lennox-Gastaut e prevenção de migrânea. Apesar de não ter sido aprovado o seu uso para o tratamento do alcoolismo, vários estudos têm apontado a eficácia do topiramato para 0 tratamento de alcoolistas, melhorando as taxas de abstinência, diminuindo a "fissura" pelo álcool e, também, os níveis dos marcadores séricos de consumo de etanol (Baltieri et al., 2009a; Johnson et al., 2007).

O topiramato é rapidamente absorvido quando ingerido por via oral, atingindo pico de concentração sérico em 2 a 3 horas. Sua biodisponibilidade é de $80 \%$. Mantém-se ligado a proteínas plasmáticas em 13 a 17\%. Sofre metabolização hepática de 10 a 30\%, conforme uso concomitante de fármacos que aumentem a metabolização hepática. Cerca de $70 \%$ da medicação é excretada inalterada pela urina (Battino et al., 2005).

Apesar de apresentar baixa interação com outros fármacos, o topiramato pode apresentar efeitos colaterais consideráveis, a saber: parestesias (em 24\%), diarreia (17\%), náusea (16\%), anorexia (13\%) e 
problemas de memória (11\%). Entre os efeitos colaterais que estão associados a maiores descontinuações, a lentificação psicomotora, problemas de memória e fadiga foram as mais relevantes (Arnone, 2005; Roy-Chengappa et al., 2006).

O topiramato deve ser administrado à noite, para minimizar efeitos colaterais. O medicamento deve ser iniciado com a menor dose possível sendo aumentado de forma lenta e gradual. Um esquema preconizado é de iniciar com $25 \mathrm{mg}$ duas vezes ao dia, aumentando $50 \mathrm{mg}$ a cada semana até dose mínima de 200 a 300 mg ao dia (Cordioli, 2011).

\subsubsection{Benzodiazepínicos}

O uso dos ansiolíticos benzodiazepínicos, como diazepam e lorazepam, tem sua aplicação no tratamento de alcoolista, sendo restrita ao tratamento da síndrome de abstinência ao álcool. Seu efeito principal ocorre por sua ação no receptor GABA do tipo A diazepínicos, que durante a síndrome de abstinência apresentam hipoativos. $O$ uso do agonista desse receptor diminuiria os sintomas de abstinência. O uso como tratamento ansiolítico de manutenção não é recomendado por risco de dependência cruzada (Schaffer e Naranjo, 1998).

\subsubsection{Inibidores seletivos da recaptação da serotonina}

A serotonina (5-hidroxitriptamina ou 5-HT) é um neurotransmissor que está associado a inúmeras funções cerebrais, e tem sido relacionado a etiologia de uma série de transtorno. A 5-HT é particularmente importante em doenças mentais, como ansiedade, depressão, esquizofrenia, transtorno alimentar, transtorno obsessivo compulsivo, síndrome do pânico e migrânea (Ye et al., 2001).

Os inibidores seletivos da recaptação de serotonina (ISRS) são usados clinicamente como antidepressivos e ansiolíticos. Eles aumentam a função serotoninérgica cerebral e têm sido apontados como responsáveis 
pela redução do consumo de álcool em animais. Estudos clínicos com os antidepressivos ISRS avaliaram a eficácia destes no tratamento de alcoolistas, mostrando resultados inconsistentes (Rosenthal, 2009).

Ensaios feitos com fluoxetina e sertralina não mostraram resultados favoráveis para o tratamento de alcoolistas; entretanto, ao analisarem os subtipos de alcoolistas, os bebedores de início tardio (aqueles que iniciaram os problemas com o consumo de álcool após os 25 anos) parecem se beneficiar do tratamento com uso de ISRS, tendo redução do consumo pesado de álcool e diminuindo o número de recaídas (Arias e Sewell, 2012).

\subsubsection{Ondansetrona}

A ondansetrona foi desenvolvida pelo Laboratório farmacêutico GlaxoSmithKline, em 1983. Sendo aprovada pelo FDA como antiemético em 1991, com o nome comercial de Zofran ${ }^{\circledR}$, ela é o primeiro composto da classe de antagonista seletivo de receptor serotoninérgico $5-\mathrm{HT}_{3}$ (5hidroxitriptamina ${ }_{3}$ ), cuja principal indicação é como antiemético, em pacientes oncológicos sobre regime quimioterápico (Simpson e Hicks, 1996).

\subsubsection{Aspectos farmacodinâmicos}

A ondansetrona, do ponto de vista químico, é um derivado da carbazolona, ligado a grupo imidazolil-metílico. Possui estrutura similar a serotonina (figura 3); apresenta um centro assimétrico e mistura racêmica $1: 1$ da forma $L$ e $D$.

A base de ondansetrona é um pó branco, sendo praticamente insolúvel em água. Já em forma de sal, o cloridrato de ondansetrona dihidratado, formulação comercializada, é um pó branco, solúvel em água ou solução salina à temperatura ambiente (Armando, 2008). 
Figura 3. Estrutura molecular da ondansetrona e serotonina.

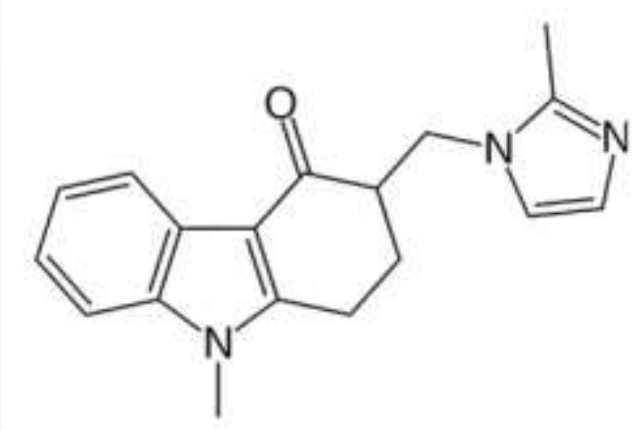

Ondansetrona

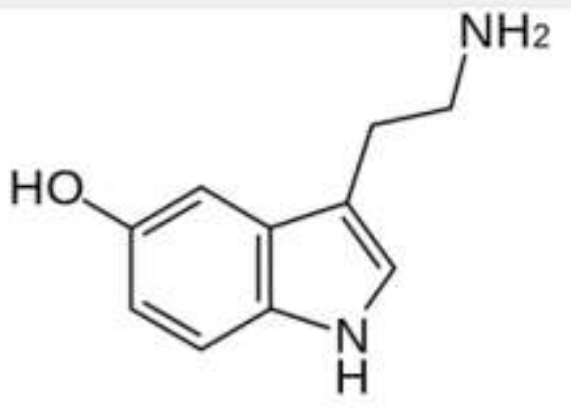

Serotonina

Modificada a partir de Armando (2008).

A ondansetrona pertence a uma classe de medicamento que atua como antagonista de receptor de serotonina, especificamente em um subtipo de receptor, o $5-\mathrm{HT}_{3}$, encontrado nos terminais do nervo vago e em certas áreas cerebrais. A classe desse fármaco é identificada pelo sufixo setrona. $O$ efeito antiemético acontece pelo bloqueio potente e seletivo dessa medicação aos receptores serotoninérgicos $5-\mathrm{HT}_{3}$, presentes em neurônios localizados no sistema nervoso periférico e no sistema nervoso central (Roila e Del-Favero, 1997).

Os receptores $5-\mathrm{HT}_{3}$ estão distribuídos em vários locais no organismo. Eles são encontrados em elevada concentração na área postrema (região quimiorreceptora), núcleo do trato solitário (centro do vômito), substância gelatinosa, núcleo trigeminal e complexo vagal dorsal na medula espinhal. Além disto, este receptor serotoninérgico é encontrado em menor concentração no córtex cerebral, hipocampo, amígdala e glândula pineal (Goodin e Cunningham, 2002).

A ondansetrona, além da ação já conhecida sobre os receptores $5-\mathrm{HT}_{3}$, apresenta afinidade sobre os outros subtipos de receptores, incluindo 5$\mathrm{HT}_{1 \mathrm{~B}}, 5-\mathrm{HT}_{1 \mathrm{C}}, 5-\mathrm{HT}_{4}$, receptores opióides e ${ }_{a 1}$-adrenérgicos. Os receptores 5$\mathrm{HT}_{3}$ apresentam ligação com vários outros neurotramissores, incluindo noradrenalina, acetilcolina, colecistoquinina, acido $y$-aminobutírico, glicina e 
dopamina. $\mathrm{O}$ antagonismo do receptor $5-\mathrm{HT}_{3}$ no nucleus accumbens está associado com a inibição da liberação de dopamina, bloqueando a percepção de prazer (Anton et al., 2006; Goodin e Cunningham, 2002).

\subsubsection{Aspectos farmacocinéticos}

A ondansetrona é absorvida no trato gastrointestinal completamente. Ao passar pelo fígado sofre metabolismo de primeira passagem, com eliminação de 30 a 40\% do fármaco. Ela atinge o seu pico de concentração plasmática em 1,5 horas após ser administrada. A ingestão de doses unitárias, maiores que $8 \mathrm{mg}$, podem causar uma desproporção na relação doses - nível sérico, o que parece ser explicado por uma redução no metabolismo de primeira passagem desse fármaco, não sendo recomendadas doses maiores que $8 \mathrm{mg}$ a cada tomada. A ligação dela às proteínas plasmáticas é de 70 a $76 \%$. A concentração desse medicamento no líquido cefalorraquidiano é apenas $15 \%$ do nível sérico. A biodisponibilidade da ondansetrona sofre aumento com a presença de alimento no trato digestivo e não se altera com uso de antiácidos (Simpson e Hicks, 1996).

O metabolismo desse fármaco ocorre predominantemente pelo fígado, através das enzimas do citocromo P450, particularmente CYP2D6, CYP1A2 e CYP3A4 (Pritchard, 1992). A ondansetrona sofre biotransformação em metabólito ativo (7- e 8-hidroxiondansetrona), que passa, em sequência, por conjugação com o ácido glucurônico e sulfato, produzindo seu metabolito inativo. A eliminação acontece pelos rins: $95 \%$ como metabólito inativo e $5 \%$ em sua forma inalterada. A meia vida de eliminação é de aproximadamente 4 horas, podendo ser menor em crianças, ou prolongada em portadores de insuficiência hepática (Bozigian et al., 1994). 


\subsubsection{Formulações disponíveis da ondansetrona}

A ondansetrona encontra-se disponível para comercialização no Brasil em duas apresentações: solução injetável e, também, comprimido. A solução injetável é comercializada em ampola de $2 \mathrm{ml}$ (4mg de cloridrato de ondansetrona) e $4 \mathrm{ml}$ (8mg de cloridrato de ondansetrona). A solução apresenta concentração de $2 \mathrm{mg}$ por $\mathrm{ml}$. Os comprimidos disponíveis para comercialização são de 4 e $8 \mathrm{mg}$ de cloridrato de ondansetrona (Armando, 2008).

\subsubsection{Segurança e efeitos colaterais}

Comparado a outras medicações, os antagonistas de receptor $5-\mathrm{HT}_{3}$ são bem tolerados e com baixa taxa de abandono do uso por efeito colateral. Em vários estudos clínicos o efeito colateral mais comum é a cefaleia. Raramente ela tem importância clínica, e normalmente quando relevante, pode ser controlada facilmente com uso de analgésicos. O mecanismo exato que leva à indução de cefaleia pela ondansetrona, não está claro, parecendo estar relacionado ao fraco antagonismo do receptor $5-\mathrm{HT}_{1}$, precipitando o processo álgico em indivíduos suscetíveis (Goodin e Cunningham, 2002).

Os efeitos adversos mais comuns são cefaleia (11-24\%), sintomas gastrointestinais (constipação 9\% e diarreia 5\%), fadiga (13\%), febre (5\%), elevação de enzimas hepáticas, rubor facial e reação de hipersensibilidade, esses últimos podem estar presentes em raros casos (Bozigian et al., 1994; Pritchard, 1992).

\subsubsection{Interação medicamentosa}

As interações que a ondansetrona pode apresentar, estão associadas às enzimas hepáticas relacionadas ao seu metabolismo (CYP3A4, CYP2D6 e CYP1A2). A rifampicina tem sido vista como medicação que provoca a redução na concentração plasmática deste antagonista de receptor 5-HT3. 
Esse efeito é atribuído à indução do metabolismo mediado pelo CYP3A4 (Goodin e Cunningham, 2002).

A ondansetrona tem sido identificada como causa de significante redução da ação de ciclofosfamida e cisplatina. Estudos mais recentes mostram que o uso concomitante do antagonista serotoninérgico com os analgésicos opióides pode reduzir o controle álgico, explicado pelo fato de a parcela da ação dos opióides sobre a dor ocorrer via receptor 5-HT (Vale et al., 2011).

\subsubsection{Transtornos mentais e o receptor de serotonina $5-\mathrm{HT}_{3}$}

A ondansetrona, além de ser usada como antiemético, tem sido testada como antidepressivo e, também, para outros transtornos mentais, como: dependência de álcool, sintomas de abstinência a opióides, tremor cerebelar, doença de Parkinson, transtorno obsessivo compulsivo, transtorno do uso de substância, síndrome de Tourette e esquizofrenia (Ye et al., 2001).

A estimulação dos receptores $5-\mathrm{HT}_{3}$ durante 0 uso de cocaína (crônico ou intermitente) está ligada ao desenvolvimento de tolerância e sensibilização. O bloqueio desse receptor, obtido com o uso prolongado de ondansetrona, pode, ao menos teoricamente, impedir a sensibilização provocada pela exposição à cocaína (King et al., 2000). Um ensaio clínico avaliando a eficácia da ondansetrona no tratamento de dependentes de cocaína foi realizado usando doses variadas de 0,5 a $8 \mathrm{mg}$ por dia. O estudo mostrou aumento do número de dias abstinentes da cocaína; a curva de efeito dose-resposta mostrou-se não linear (Johnson et al., 2006).

Estudos em animais mostram que o uso de antagonista de receptor 5$\mathrm{HT}_{3}$, reduz a presença de sintomas de abstinência em usuários crônicos de opióide que receberam naloxone. Esse efeito pode ser explicado pela influência do sistema serotoninérgico na instalação dos sintomas de abstinência. Dessa forma, pode-se pensar que a ondansetrona pode ser útil, 
ao menos hipoteticamente, para o tratamento de sintomas de abstinência de opióide presentes em dependentes de heroína (Pinelli et al., 1997).

A psicose é uma condição associada com a atividade dopaminérgica da via mesolímbica. Vários estudos suportam a ideia de que a ondansetrona pode afetar a neurotransmissão da via mesolímbica, podendo ocasionar melhora na disfunção dopaminérgica presente nos transtornos psicóticos. $O$ uso dessa medicação, em associação com antipsicóticos, foi testado em portadores de esquizofrenia (na dose de 8mg/dia e $12 \mathrm{mg} /$ dia durante 12 semanas), havendo redução dos sintomas psicóticos e do desenvolvimento de discinesia tardia (Akhondzadeh et al., 2009; Sirota et al., 2000; Zhang et al., 2006).

Em pacientes com doença de Parkinson é encontrada uma hiperestimulação dos receptores serotoninérgicos centrais, que tem sido associada ao surgimento de sintomas psicóticos nesses pacientes. Ensaios clínicos usando doses elevadas de ondansetrona (12 a 24mg por dia), junto com levodopa, durante oito semanas, mostraram a eficácia do antagonista em melhorar a alucinação visual, os delírios paranoides, a confusão e o funcionamento global dos portadores dessa enfermidade (Zoldan et al., 1995).

O sistema serotoninérgico e dopaminérgico tem sido implicado na modulação do transtorno obsessivo compulsivo (TOC). Os receptores 5-HT3 afetam a liberação de dopamina no córtex do sistema mesolímbico e o antagonismo desse receptor, feito pela ondansetrona, pode ser usado como potencial colaborador no tratamento do TOC. Ensaios clínicos têm sido conduzidos, avaliando a resposta de portadores de TOC refratário à combinação de ondansetrona, antidepressivo serotoninérgico e antipsicótico. Os pacientes obtiveram melhora nos sintomas obsessivos e compulsivos, as doses utilizadas, variaram de $0,5 \mathrm{mg}$ a $3 \mathrm{mg}$ por dia, durante 8 a 12 semanas (Hewlett et al., 2003; Pallanti et al., 2009).

O antagonismo do receptor 5-HT3, feito pela ondansetrona, pode diminuir a hiperatividade dopaminérgica, da via mesolímbica, presente na Síndrome de Gilles de La Tourette. Um estudo piloto mostrou que o uso da 
dose máxima, de $8 \mathrm{mg}$ a 16mg por dia, durante 3 semanas, esteve associado à melhora dos tiques (Toren et al., 1999).

\subsubsection{Ondansetrona e alcoolismo}

$\mathrm{O}$ antagonista de receptor $5-\mathrm{HT}_{3}$ tem sido apontado como promissor agente no tratamento do alcoolismo. Número crescente de estudos tem apontado o envolvimento do receptor $5-\mathrm{HT}_{3}$ nos fenômenos neuroquímicos e comportamentais do álcool, incluindo a intoxicação alcoólica, bem como, na "fissura" e dependência ao álcool (Ye et al., 2001).

Estudos moleculares mostram que o álcool atua sobre o receptor 5$\mathrm{HT}_{3}$, através da ação do etanol sobre as proteínas deste receptor e sobre as correntes iônicas, efeito este que pode ser bloqueado por antagonistas seletivos do receptor 5- $\mathrm{HT}_{3}$ (Zhou e Lovinger, 1996).

As vias dopaminérgicas do córtex mesolímbico estão relacionadas à sensação de recompensa provocada pelo consumo do álcool e, também, de outras substâncias de abuso. Estudos em animais mostram densa distribuição de receptores $5-\mathrm{HT}_{3}$ nos terminais neuronais do córtex mesolímbico que modulam a liberação dopaminérgica nesta via. O bloqueio seletivo dos receptores $5-\mathrm{HT}_{3}$ diminui a liberação dopaminérgica e reduz 0 consumo do álcool em modelos animais (Beardsley et al., 1994; Kilpatrick et al., 1996).

Estudos farmacológicos sugerem que esse receptor, também, está envolvido com o efeito de recompensa ocasionado pelo consumo do álcool. Por exemplo, o antagonismo do receptor $5-\mathrm{HT}_{3}$ diminui o consumo de álcool em modelos animais. Foi observada a redução da função serotoninérgica e dopaminérgica na via mesolímbica durante o período de abstinência ao álcool (Barnes e Sharp, 1999; McBride e Li, 1998).

O primeiro estudo para avaliar a eficácia da ondansetrona sobre o consumo de álcool em humanos foi realizado em 1993, dois anos após ter sua aprovação como antiemético pelo FDA. O uso de $4 \mathrm{mg}$ de cloridrato de ondansetrona atenuou o reforço positivo obtido com 0 consumo de 
pequenas doses de álcool em voluntários saudáveis (Johnson et al., 1993). Estudos pré-tratamento avaliando a ação do antagonista de receptor 5-HT3, sobre os efeitos físicos e subjetivos do álcool, mostraram que a dose de $8 \mathrm{mg}$, e não $0,25 \mathrm{mg}$, de ondansetrona aumentou as sensações de sonolência e desconforto desencadeado pelo consumo do álcool (Swift et al., 1996; Doty et al., 1994).

O primeiro ensaio clínico feito com a ondansetrona no tratamento de alcoolistas foi realizado em 1994, usando a dose de 0,5 mg e $4 \mathrm{mg}$ do antagonista de receptor $5-\mathrm{HT}_{3}$ por dia, durante 6 semanas. Esse estudo mostrou que, na última semana do estudo, houve a diminuição do consumo de bebida entre os alcoolistas que usaram a dose de 0,5mg por dia (Sellers et al., 1994). Esse estudo indicou a necessidade de testar a eficácia da ondansetrona no tratamento do alcoolismo em maior escala e por maior período. Ele, também, apontou para a possibilidade da curva dose-resposta dessa medicação não ser retilínea.

Partindo da hipótese que o antagonismo do receptor $5-\mathrm{HT}_{3}$ poderia ser mais efetivo no tratamento de alcoolistas com maior disfunção serotoninérgica, foram realizados estudos com dependentes de álcool classificados como dependentes com início precoce e de início tardio (os primeiros tinham maior disfunção serotoninérgica do que os tardios). Foram usadas três doses distintas, $1 \mathrm{mcg} / \mathrm{Kg}, 4 \mathrm{mcg} / \mathrm{Kg}$ e $16 \mathrm{mcg} / \mathrm{Kg}$ duas vezes por dia, durante 12 semanas. Os resultados mostraram que os bebedores de início precoce tiveram melhora no número de dias bebidos, no volume consumido por dia bebido e maior período de abstinência, para as três dosagens de ondansetrona testada, com o maior efeito para a dose de $4 \mathrm{mcg} / \mathrm{Kg}$. Apontaram também que os bebedores de início tardio não se beneficiaram da ondansetrona em dose baixa (Johnson et al., 2000a). Quando foi avaliada a "fissura" pelo álcool entres esses bebedores, somente a dose de $4 \mathrm{mcg} / \mathrm{Kg}$ duas vezes ao dia provou reduzir o desejo intenso em consumir a bebida nos bebedores de início precoce, e ainda, as doses baixas $(1 \mathrm{mcg} / \mathrm{Kg})$ estavam associadas ao aumento do desejo nos bebedores de início tardio (Johnson et al., 2002). 
Estudos que avaliam o polimorfismo genético da região responsável pela produção de proteínas transportadoras da recaptação de serotonina postulam que os bebedores de início precoce apresentem o genótipo L/L (com disfunção serotoninérgica) e que os bebedores tardios apresentem o genótipo S/L ou S/S (sem disfunção serotoninérgica). Ensaios clínicos demonstram que a ondansetrona beneficia os portadores do genótipo L/L, promovendo maior abstinência e menor consumo do álcool, e não influencia os portadores de genótipo S/L e S/S. Isso indicou que o uso de baixas doses de ondansetrona $(0,5 \mathrm{mg}$ por dia) beneficia um grupo específico de dependentes de álcool, com tendência a maior disfunção serotoninérgica (Johnson et al., 2011; Kenna et al, 2009).

A associação entre o antagonista de receptor 5-HT3 e antagonista de receptor mu-opióide tem sido estudada em modelos animais. Esta associação pode produzir sinergismo, melhorando a modulação sobre a via da recompensa, reduzindo o reforço positivo induzido pelo consumo de álcool. Estudos clínicos têm mostrado que associação entre ondansetrona (4mcg/Kg duas vezes ao dia) e naltrexona (25mg por dia) reduz a "fissura" pelo álcool, melhora as taxas de abstinência e reduz o consumo de bebida alcoólica durante o tratamento (Johnson et al., 2002; Ait-Daoud et al., 2001).

$\mathrm{O}$ antagonista de receptor de $5-\mathrm{HT}_{3}$ está associado à melhora nas taxas de abstinência e diminuição do consumo do álcool, entre bebedores com maior vulnerabilidade genética e disfunção serotoninérgica, quando essa medicação é usada em baixas doses, o que parece estar relacionado à melhora na disfunção serotoninérgica e não ao bloqueio dos neurônios dopaminérgicos na região mesolímbica (Koulu et al, 1990).

Como a curva dose resposta da ondansetrona, no tratamento de alcoolistas, não parece ser linear e alguns pesquisadores têm apontado que a ação do antagonista 5- $\mathrm{HT}_{3}$ na liberação dopaminérgica é mais efetiva com doses mais elevadas do antagonista (8 ou 16mg por dia), existe o interesse crescente de avaliar esta medicação em doses elevadas no tratamento dos alcoolistas (Johnson et al., 2006; Gerlach, 1991). 


\subsection{Adesão ao tratamento}

O tratamento de dependentes de álcool deve buscar mais que o controle do consumo (foco na abstinência), deve buscar a recuperação do indivíduo como um todo (foco na autonomia). Entre os regimes de atenção aos dependentes de drogas existentes no Brasil e no mundo, pode-se citar: hospitalar, ambulatorial, comunidades terapêuticas, hospital dia e grupos de mútua ajuda. Independente de qual seja o modelo escolhido, os alcoolistas migram entre eles, não existindo um modelo isento de risco de abandono (Monteiro et al., 2011).

Um dos principais objetivos dos programas terapêuticos de alcoolistas é a promoção de abstinência. Quase a totalidade dos pacientes que abandonam o tratamento acaba recaindo no consumo do álcool. Taxa de abandono vista durante o tratamento oscila entre $40-80 \%$. (Simpson et al., 1997; Stark, 1992; Baekeland et al., 1975). Assim como em outras doenças crônicas, no alcoolismo o abandono do tratamento é um dos grandes desafios a serem vencidos. Nos últimos 30 anos, pesquisas têm sido realizadas para entender melhor as elevadas taxas de desligamento precoce do tratamento.

Cada vez mais tem se discutido a importância da adesão dos pacientes aos programas terapêuticos, independente do alcance da abstinência. A permanência no tratamento, apesar da incapacidade de interromper o consumo do álcool, pode reduzir os malefícios desse consumo, sem contar que parte dos alcoolistas consegue manter um consumo menos intenso do álcool (Baltieri e Corrêa Filho, 2012; Graff 2009; Lannery et al., 2003).

Muitas pessoas que procuram tratamento em programas para dependência não chegam a iniciar o primeiro atendimento do programa, abandonando $\mathrm{o}$ tratamento antes de experimentarem propriamente $\mathrm{O}$ programa oferecido. Esse fato parece estar ligado à lacuna existente entre $o$ desejo de procurar tratamento e a capacidade dos serviços terapêuticos de absorver esse paciente, ocasionando um período, muitas vezes longo, em 
que o alcoolista pode não resistir à bebida e acabar desistindo de iniciar o tratamento (Capoccia et al., 2007). Outra parcela significante de dependentes de álcool inicia o tratamento, mas acaba abandonando durante o processo terapêutico.

A desistência do programa terapêutico traz algumas implicações negativas para os alcoolistas, entre elas podemos citar: agravos à saúde devidos ao retorno ao consumo do álcool e ao descuido com doenças comórbidas; problemas no relacionamento familiar, normalmente já corrompido pelo longo período de exposição à bebida; prejuízos financeiros decorrentes do gasto com a compra da bebida, com os agravos à saúde e, também, com outras consequências do uso do álcool (acidentes automobilísticos e perda de valores em espécie); por fim, os problemas com o trabalho são resultantes do baixo rendimento, faltas e atrasos frequentes e da incapacidade de manter sua rotina (Hoffman et al., 2011).

Além dos prejuízos para os alcoolistas, citados acima, as faltas aos atendimentos e o abandono precoce ao tratamento têm um grande impacto para os programas terapêuticos. Esses comportamentos ocasionam a diminuição do tempo de atendimento dos pacientes, pois o tempo dedicado a cada atendimento é influenciado pelo número de pessoas que necessitam do atendimento. Como os profissionais da saúde ficam esperando o alcoolista faltante, deixam de atender outros pacientes. Além disto, existe um grande impacto financeiro, pois parte significativa dos recursos disponíveis é ofertada para pacientes que acabam desistindo de seu tratamento. Assumindo que quase metade dos alcoolistas desiste, seria necessário ofertar tratamento para dois pacientes a fim de que um complete o programa terapêutico. De certa forma, existe um paradoxo nesta situação, pois a aparente superlotação e a sobrecarga dos profissionais envolvidos nos programas terapêuticos. Isso contrasta com esses atendentes ociosos, aguardando seus pacientes que não chegam para atendimento (Carr et al., 2008; Gallant et al., 1966).

Os fatores relacionados à desistência do tratamento têm sido divididos em dois tipos: as caraterísticas relacionadas ao paciente e às 
relacionadas aos programas terapêuticos. As características clínicas dos alcoolistas parecem influenciar pouco no desejo de iniciar o tratamento e na aderência ao mesmo. Algumas condições têm sido ligadas a essa adesão, entre elas estão: a gravidade da dependência de álcool (existe uma correlação negativa entre essa gravidade e a capacidade de manutenção do tratamento); idades mais jovens (quanto mais novo tiver iniciado a dependência mais frequentes a disfunções de neurotransmissão); pressão judicial (alcoolistas que por determinação judicial são encaminhados para tratamento), presença de pessoas com dependência na mesma casa, especialmente familiares, estabilidade social e familiar (alcoolista que conta com uma rede de pessoas motivadas a ajudá-lo tende a ter uma evolução mais favorável), assistência privada de saúde (que acaba possibilitando o acesso a todos os recursos necessários para seu tratamento) e história de tratamentos prévios bem sucedidos (Hser et al., 1998; Orme e Boswell, 1991; Leigh et al., 1984).

Alguns fatores relacionados aos programas terapêuticos têm sido associados a maiores taxas de abandono ao tratamento. Entre essas podemos enumerar: o tempo de espera para a consulta (quanto maior 0 tempo gasto esperando 0 atendimento, mais frequente as faltas nas consultas seguintes). Alguns autores relacionam esse intervalo à impressão de acolhimento; portanto, pode ocorrer a impressão de desamparo por parte do paciente (Ettner et al., 2006). A experiência dos profissionais envolvidos no tratamento, o tipo de aliança estabelecido entre o profissional e o paciente, o tempo entre a busca de tratamento pelo paciente e o primeiro atendimento no programa também influenciam a adesão. Esse intervalo tem sido ligado às faltas nos atendimentos subsequentes, especialmente se este intervalo for maior que 14 dias (Stasiewick e Stalker, 1999; Thom et al., 1992; Rees et al., 1984). Em 2011, Hoffman et al. (2011) avaliando a associação entre 0 intervalo para 0 primeiro atendimento e a adesão às quatro primeiras consultas, demonstraram uma correlação inversa: quanto maior a espera para o início do tratamento, após a busca de ajuda, menor a frequência encontrada nos quatro primeiros encontros. 
Cada vez mais se tem apontado a necessidade de identificar os pacientes com maior risco de desligamento precoce do tratamento para poder individualizar as terapêuticas ofertadas e reduzir as chances de desistência. Por outro lado, os programas terapêuticos devem evoluir e aperfeiçoar seus processos. 


\section{OBJETIVOS}

\subsection{Objetivos gerais}

Avaliar a eficácia e segurança da ondansetrona, na dose de $16 \mathrm{mg}$ dia, no tratamento de dependentes de álcool.

Desenvolver uma tipologia para alcoolistas e verificar a associação dos diferentes tipos de dependentes com a adesão dos tratamentos farmacológicos propostos.

\subsection{Objetivos específicos}

Avaliar as taxas de retenção ao tratamento farmacológico do alcoolismo;

Analisar as características clínicas e sócio-demográficas dos alcoolistas, identificando possíveis razões para o abandono precoce do tratamento;

Comparar os resultados de diferentes terapias medicamentosas e identificar se existe uma com maior eficácia;

Contribuir com a formulação de tipologia, de fácil aplicação clínica, que possa identificar pacientes com maior risco de descontinuar o tratamento. 


\section{JUSTIFICATIVA}

O alcoolismo é um transtorno com elevada taxa de recaída, necessita na maioria das vezes de uma abordagem complexa. Os medicamentos têm sido elo importante nesses tratamentos. Contudo, não existe uma medicação resolutiva e as drogas existentes beneficiam parcelas dos alcoolistas. Há necessidade de desenvolver novas propostas terapêuticas que possam beneficiar esses dependentes.

A ondansetrona surge como uma medicação promissora dentro dessas novas propostas. Como ela não tem seu mecanismo de ação claro e pelo fato de não ter uma curva dose-resposta linear, no tratamento de alcoolistas, esse medicamento necessita ser testado em dose diferente das baixas doses usuais, como por exemplo, a dose de $16 \mathrm{mg} / \mathrm{dia}$, para melhor compreender o efeito desse medicamento no tratamento de dependentes de álcool.

Um dos grandes obstáculos nos programas terapêuticos oferecidos para os dependentes de álcool é o abandono do tratamento, que muitas vezes precede ou acompanha a recaída no consumo da substância. Desenvolver estratégias que possam contribuir com a melhora na aderência terapêutica é peça fundamental para mudar o curso desse transtorno. 


\section{METODOLOGIA}

\subsection{PROGREA-IPq-HCFMUSP}

O Grupo Interdisciplinar de Estudos de Álcool e Drogas do Instituto de Psiquiatria do Hospital das Clínicas da Faculdade de Medicina da Universidade de São Paulo (PROGREA) foi fundado em 1981 por residentes do Instituto de Psiquiatria do Hospital das Clínicas da Faculdade de Medicina da Universidade de São Paulo, com a finalidade de estudo e de tratamento de pacientes com alcoolismo. Em 1987, associou-se ao GREF (Grupo de Estudos de Farmaco-dependências), que existia na mesma instituição, desde 1983, ampliando seus objetivos, que também passaram a incluir o estudo e o tratamento de pacientes que apresentassem dependência de outras substâncias psicoativas.

Essa fusão realizou-se em função das similaridades entre os objetos de estudo e entre as abordagens metodológicas e conceituais de ambos os grupos.

Desde sua fusão, o PROGREA tem se expandido. Atualmente conta, em sua equipe, com psiquiatras, residentes em Psiquiatria, psicólogos, acadêmicos de Medicina e Psicologia, terapeuta ocupacional, preparador físico, assistente social, enfermeiros, alunos de pós-graduação (mestrado e doutorado) e estrutura de secretariado distinto. $O$ grupo atua em três esferas: pesquisas com linhas definidas, com publicação de elevada relevância científica; ensino através de cursos reconhecidos nacionalmente e com o programa de estágio para estudantes; por fim, assistência prestada por ambulatórios didáticos e específicos, estes ligados às pesquisas em andamento e, também, através da enfermaria de comportamentos impulsivos (ECIM), que dispõe de 13 leitos para internação. Ainda, existem programas voltados à prevenção de risco do uso/abuso de drogas desenvolvidos por este grupo. 


\subsection{Estrutura do estudo}

O estudo foi realizado em duas etapas: a primeira compreende a realização de um ensaio clínico randomizado, duplo-cego placebo controlado para avaliar a eficácia e segurança da ondansetrona no tratamento de dependentes de álcool; a segunda etapa compreende a comparação de diferentes terapêuticas farmacológicas, a partir da combinação de bancos de dados, gerados com três ensaios clínicos realizados no PROGREA, para identificar características que estivessem ligadas à aderência ao tratamento, bem como, formular uma tipologia, com base em características presentes no início do tratamento, que possa ser usada para identificar sujeitos com maior risco de abandonar o tratamento.

A combinação dos bancos de dados foi realizada para aumentar o poder de identificação de variáveis relacionadas com a retenção no tratamento dos alcoolistas. Essa fusão só foi possível porque os ensaios clínicos tinham metodologia similar e foram coordenados pelo mesmo médico, a saber, o orientador desta tese.

\subsection{O ensaio clínico com ondansetrona}

$\mathrm{Na}$ primeira parte deste estudo foi realizado um ensaio clinico com a ondansetrona. A execução deste projeto só foi possível porque houve o financiamento da pesquisa pela Fundação de Amparo a Pesquisa do Estado de São Paulo (FAPESP), $n^{\circ}$ 07/54009-8, além do apoio institucional da Universidade de São Paulo (USP), representado, neste projeto, pelo Instituto de Psiquiatria do Hospital das Clínicas da Faculdade de Medicina da USP.

\subsubsection{O local do estudo e pacientes}

A presente pesquisa foi desenvolvida no ambulatório assistencial do Grupo Interdisciplinar de Estudos de Álcool e Drogas do Instituto de 
Psiquiatria do Hospital das Clínicas da Faculdade de Medicina da Universidade de São Paulo (PROGREA), entre janeiro de 2008 a dezembro de 2010.

Procuram atendimento no ambulatório assistencial do PROGREA pessoas pertencentes a diversas classes sociais, encaminhadas por serviços públicos, consultórios particulares e, ainda, por demanda espontânea (Baltieri, 2002).

O tratamento oferecido nesse serviço consiste em atendimento ambulatorial multiprofissional (atendimento médico, psicoterapia grupal, terapia individual e terapia familiar). Também, existe um grupo de mútua ajuda, o $A A$, que faz suas reuniões no mesmo local e dia do ambulatório do PROGREA. Os atendimentos são padronizados, permitindo que os pacientes tenham acesso a todos os recursos disponíveis, conforme a necessidade de cada caso. A internação hospitalar é um recurso que pode ser utilizado durante o tratamento dos alcoolistas, conforme critérios já normatizados pelo grupo.

\subsubsection{Desenho do ensaio clínico}

Para analisar a eficácia e segurança da ondansetrona, foi realizado um ensaio clínico com características de estudo duplo-cego randomizado placebo controlado.

Conforme os pacientes eram incluídos no estudo, foram alocados em dois grupos: um grupo medicado com placebo (grupo placebo) e outro, que recebeu a ondansetrona (grupo ondansetrona).

Todos os participantes passaram por duas semanas de desintoxicação, antes de iniciar o uso da medicação. Após começarem a usar as medicações, esses sujeitos foram seguidos por mais doze semanas e nesse período receberam intervenções focadas na promoção de abstinência. Os participantes foram avaliados quanto ao consumo de álcool e presença de efeitos colaterais. Durante todo o acompanhamento foram realizados exames clínicos e laboratoriais, estes últimos coletados no início, na sexta e 
décima segunda semanas do ensaio clínico. Ao completarem o estudo, os pacientes foram encaminhados para manutenção do tratamento.

\subsubsection{Randomização e condição do cegamento}

Para a randomização dos participantes no ensaio clínico foi criada uma tabela de números aleatórios, de 1 a 200, no site "www.random.org". A partir dessa tabela de números aleatórios, conforme os pacientes eram eleitos para participar do estudo, recebiam a numeração referente à sua posição na tabela. Ser o número par ou ímpar foi o critério escolhido para indicar em qual grupo o sujeito seria alocado (placebo ou ondansetrona).

A informação do critério numérico (par ou ímpar) era de conhecimento exclusivo dos auxiliares de pesquisa responsáveis pela confecção da medicação. Nem mesmo os distribuidores da medicação conheciam esses dados. A randomização seguiu-se até que existissem ao menos 50 integrantes em cada grupo.

Para a confecção e distribuição de todas as cápsulas, foi contratada a Unidade de Farmácia do Instituto de Psiquiatria do Hospital das Clinicas da Faculdade de Medicina da Universidade de São Paulo. As medicações foram confeccionadas de modo que todas as cápsulas tivessem a apresentação e o peso idênticos. As pessoas responsáveis pela confecção dos medicamentos eram as únicas que sabia qual era a medicação usada, pois as cartelas eram individualizadas e entregues por atendentes distintos aos pacientes. O médico assistente e avaliador não tinham a informação de qual era o grupo do participante, desconhecendo quem recebia o placebo ou a ondansetrona.

O banco de dados gerado pela pesquisa era controlado por um auxiliar da pesquisa, que permaneceu cego para a medicação. O relatório, a distribuição das tabelas e a realização da chamada (recall) dos pacientes que deixaram de comparecer às consultas foram realizados por auxiliares que também eram cegos para a medicação prescrita. $O$ código da 
randomização só foi revelado pelos responsáveis da farmácia ao término do estudo.

\subsubsection{Considerações sobre medicamento e cartelas}

A confecção das cápsulas foi padronizada para atender a condição de "duplo-cego". As cápsulas de ondansetrona foram feitas com $8 \mathrm{mg}$ desta medicação em pó. O placebo era feito de amido (apresentava a mesma coloração) e confeccionado com o mesmo peso da medicação. Todos os pacientes eram orientados a tomar as cápsulas de 12 em 12 horas.

As cápsulas eram organizadas em cartelas numeradas (de um a doze, conforme a semana que deveriam ser usadas). Em cada cartela estavam indicados o dia e o horário do uso das medicações, a fim de que não houvesse problemas na administração individual das mesmas.

A entrega das cartelas foi realizada em cada retorno às consultas (no primeiro mês semanalmente e, após isto, de duas em duas semanas). Sempre que os pacientes recebiam as novas cartelas, era conferido o uso das cartelas anteriores.

\subsubsection{Grupos e acompanhamento}

Entre fevereiro de 2008 a janeiro de 2010, no PROGREA, 172 pessoas com síndrome de dependência do álcool foram convidadas a participar da pesquisa. Ao serem informadas sobre a pesquisa 49 desses pacientes, optaram por não participar do estudo. Dos 123 sujeitos restantes, 21 foram excluídos da pesquisa por não contemplarem todos os critérios. Os 49 pacientes que não quiseram participar do estudo e os 21 participantes excluídos da pesquisa foram encaminhados para o tratamento no ambulatório do PROGREA. Foram eleitos para participar do ensaio clínico 102 sujeitos. Com a randomização foram incluídos no grupo placebo 52 participantes e no grupo ondansetrona 50 outros (figura 4). 
No primeiro encontro, após os pacientes assinarem o termo de consentimento pós-informado, eles passaram por duas semanas de desintoxicação que previa uso de medicação: lorazepam até 6mg/dia, dependendo da intensidade dos sintomas de abstinência ao álcool; uso de Vitamina $B_{1} 300 \mathrm{mg} / \mathrm{dia}$, complexo $B$ e acido fólico. Nestas duas semanas, os participantes realizavam avaliação clínica e colhiam exames laboratoriais padronizados na pesquisa (anexo $\mathrm{C}$ ).

Figura 4. Fluxograma dos pacientes que foram convidados a participar do ensaio com ondansetrona.

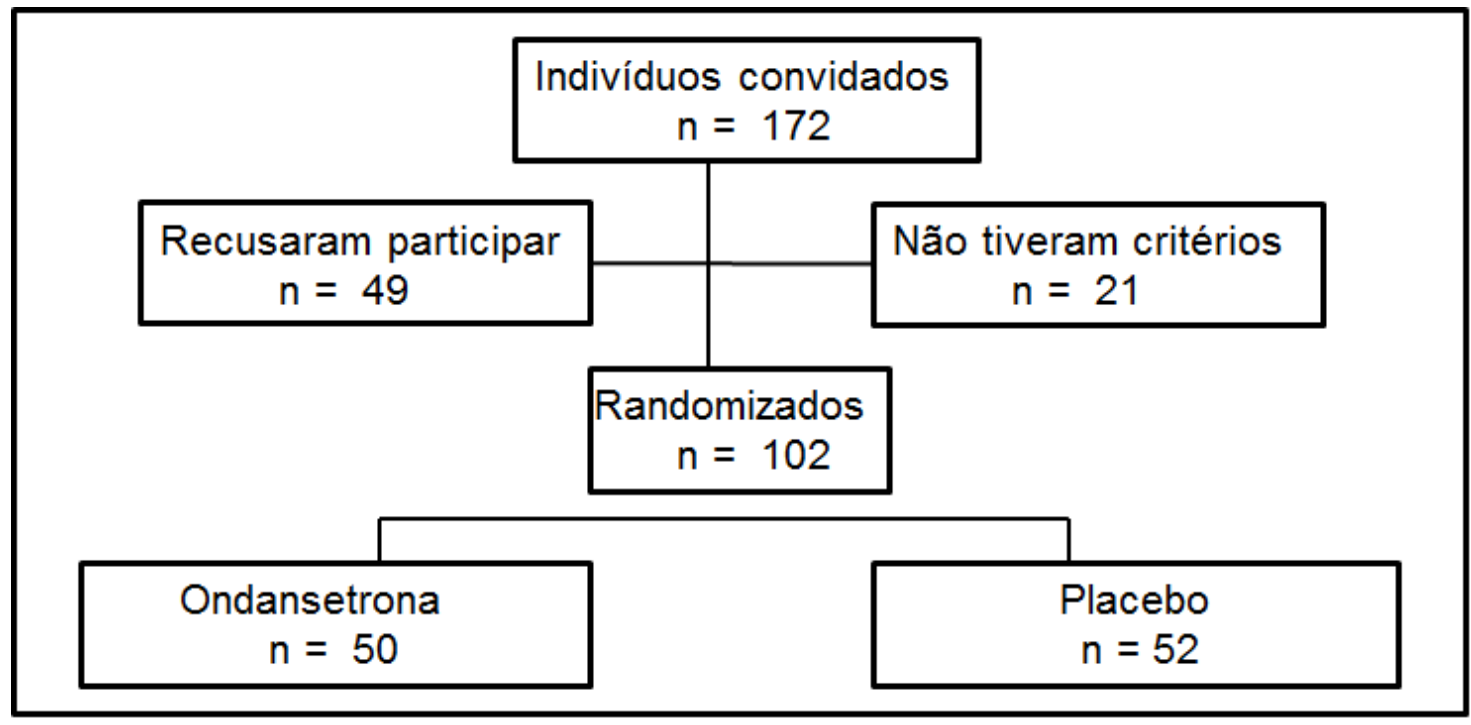

Após esse período de desintoxicação, no segundo encontro, dava-se início ao uso das medicações avaliadas. Uma entrevista clínica minuciosa era realizada, resultando no preenchimento do protocolo comum do PROGREA (anexo E). Os sintomas de abstinência foram avaliados pela escala de abstinência - CIWA-Ar, anexo H (Shaw et al.,1981). O desejo em consumir a bebida foi mensurado usando escala que avalia a compulsão e obsessão pela bebida - OCDS, anexo K (Anton et al., 1995). O humor foi avaliado por escala de depressão consagrada - Hamilton-21, anexo J (Hamilton, 1960). A gravidade dos problemas com o uso de álcool foi medida por duas escalas distintas - SADD (Raistrick et al., 1983) e AUDIT (Babor et 
al., 1992b), anexos $\mathrm{F}$ e G, respectivamente. Foi utilizada também a escala de acompanhamento de alcoolistas - ESA, anexo I (Andrade et al., 1988).

Após o início do uso da medicação testada (chamada de semana zero) os integrantes eram vistos semanalmente, no primeiro mês. Nos últimos dois meses, eles retornavam a cada duas semanas (tabela 7).

O consumo de álcool, o uso de outras substâncias (medicamentos), a aderência à medicação, a participação aos alcoólicos anônimos (AA) e a presença de efeitos colaterais avaliados pela escala UKU (Lingjaerde et al., 1987), eram realizados em todos os encontros (anexo L). Confirmações a respeito das informações cedidas pelos pacientes foram feitas, em vários momentos, com seus familiares, fato que poderia ocorrer ao acaso ou quando necessário.

$\mathrm{Na}$ sexta e na última semana do tratamento, os participantes eram reavaliados quanto a sintomas depressivos, "fissura" pelo álcool e pela escala de seguimento de alcoolistas (Hamilton-21, OCDS e ESA, respectivamente). Os exames laboratoriais foram novamente coletados nesses momentos.

Os pacientes foram acompanhados por 12 semanas de tratamento, tempo este utilizado em vários estudos com desenhos similares (Baltieri et al., 2008; Johnson et al., 2003). Ao término do tratamento foi proposto a todos os pacientes o encaminhamento para a manutenção em centros especializados; os que preferiram permanecer no PROGREA tiveram sua solicitação atendida. 
Tabela 7. Cronograma das consultas e distribuição de cápsulas.

\begin{tabular}{|c|c|c|c|c|}
\hline Consulta & Finalidade & Instrumentos usados & Procedimentos & Semana do estudo \\
\hline \multirow[t]{2}{*}{$\cos _{1}$} & T. consentimento & CID-10, CIWA-AR, Protocolo comum. & 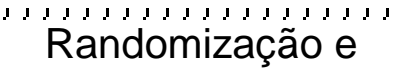 & -2 \\
\hline & & & Coleta de exames & \\
\hline $2^{\underline{a}}$ & Avaliação médica & $\begin{array}{l}\text { Protocolo comum, ESA, SADD, AUDIT, } \\
\text { Hamilton-21, OCDS, }\end{array}$ & $\begin{array}{l}\text { Início da medicação } \\
\text { testada }\end{array}$ & 0 \\
\hline $3^{\mathrm{a}}$ & Avaliação médica & UKU & - & 1 \\
\hline $4^{\underline{a}}$ & Avaliação médica & UKU & - & 2 \\
\hline $5^{\mathrm{a}}$ & Avaliação médica & UKU & - & 3 \\
\hline $6^{\mathrm{a}}$ & Avaliação médica & UKU & - & 4 \\
\hline $7^{\underline{a}}$ & Avaliação médica & Hamilton-21, OCDS, ESA e UKU & Coleta de exames & 6 \\
\hline $8^{\underline{a}}$ & Avaliação médica & UKU & - & 8 \\
\hline $9^{\text {a }}$ & Avaliação médica & UKU & - & 10 \\
\hline $10^{\mathrm{a}}$ & Término do estudo & Hamilton-21, OCDS, ESA e UKU & Coleta de exames & 12 \\
\hline
\end{tabular}

CIWA-AR = escala de sintomas de abstinência ao álcool, Clinical Institute Withdrawal Assessment; SADD = escala de gravidade do alcoolismo, Short Alcohol Dependence Date; AUDIT = Escala de gravidade do consumo do álcool, Alcohol Use Disorders Identification Test; OCDS = Escala de "fissura" pelo álcool, Obsessive-Compulsive Drinking Scale; Hamilton-21, Escala de Depressão Hamilton com 21 itens; UKU = escala de efeitos colaterais, Ugvald for Kliniske Undersgelse. 
Em cada um dos encontros, todos os participantes receberam intervenções cognitivo-comportamentais breves, manualizadas e padronizadas em nosso serviço. O objetivo dessas intervenções foi aumentar as habilidades pessoais de lidar com situações de alto risco, que pudessem precipitar uma recaída. Durante o acompanhamento, os pacientes foram orientados a monitorar situações diárias boas e ruins e essas situações foram discutidas com seu médico e, quando possível, relacionadas ao comportamento de beber. Os seguintes tópicos foram padronizados e trabalhados no decorrer do tratamento com cada paciente: gerenciamento de humor depressivo, assertividade, habilidade para recusar a bebida, melhoria da rede de apoio social e prevenção de recaída. Os pacientes foram estimulados a participarem de grupo de mútua ajuda (AA).

O cálculo da quantidade de álcool consumida por cada participante (quadro 2) foi realizado a partir do consumo diário descrito de bebida, metodologia adotada em outros estudos (Instituto Nacional de Câncer, 2004; World Health Organization, 2000).

Quadro 2. Fórmula para calcular o volume de álcool consumido por dia para cada paciente.

Volume de bebida ${ }^{1} \mathrm{x}$ densidade do álcool ${ }^{2} \mathrm{x}$ porcentagem de álcool na bebida ${ }^{3}$

1 volume de bebida consumida por cada participante; ${ }^{2}$ densidade do álcool $(0,8 \mathrm{~g} / \mathrm{ml}) ;{ }^{3}$ percentagem de álcool em cada tipo de bebida (cerveja $3 \%$, vinho $12 \%$, conhaque $40 \%$, pinga, vodca e uísque $50 \%$ ).

\subsubsection{Critérios de eficácia do ensaio clínico}

Os marcadores biológicos foram utilizados como critério de eficácia, por refletirem objetivamente o consumo de bebidas alcoólicas. Foram escolhidos como marcadores: a gama glutamil transpeptidase (GGT); o aspartato transaminase (ASP ou TGO); alanina transaminase (ALT ou TGP); por fim, o volume corpuscular médio (VCM). Eles são classicamente 
utilizados para esta finalidade em vários estudos (Chick et al., 1981; Sharpe et al., 1996).

O tempo de abstinência continuada (TAC) é o tempo entre o início do estudo (medicação testada) e o primeiro gole de álcool, expresso em dias. Ele foi analisado, utilizando-se o princípio da "Intenção de Tratar", desta forma, o abandono ao tratamento foi considerado, nesta análise, como indicador de recaída. O tempo de abstinência continuada foi analisado através da curva de sobrevida.

O tempo total de abstinência (TTA), que representa o número total de dias abstinentes, durante o estudo - em dias, foi usado para indicar tempo que o paciente ficou abstinente durante o período em estudo.

O tempo para o primeiro consumo pesado de álcool (TCP) é o intervalo de tempo entre o início do uso da medicação até o primeiro consumo pesado da bebida alcoólica, que foi definido como maior que 70 gramas de álcool por dia (Silveira et al., 2008; National Institute on Alcohol and Alcoholism, 2005).

A proporção de dias abstinentes (PDA) e a proporção de dias de consumo pesado do álcool (PCP) por semana de estudo foram calculados. A relação entre o número de dias em que não houve consumo de bebida na semana e os sete dias da semana em questão dão valor do PDA. O valor do PCP foi calculado pela razão entre o número de dias com consumo pesado de álcool na semana, divididos pelos sete dias dessa semana. Foi utilizado como referência para definir "beber pesado" o consumo diário maior que 5 doses de bebida ( $70 \mathrm{~g}$ de álcool).

A retenção no tratamento foi entendida como o término do tratamento (ter completado as 12 semanas do estudo), independente do consumo ou não de bebida nesse período. A adesão está associada à aceitação da abordagem terapêutica, mesmo que o paciente mostre-se incapaz de conseguir a abstinência plena, o que contempla a política de redução de danos estabelecida pelo Ministério da Saúde do governo federal (Brasil, 2004). 


\subsubsection{Integridade da condição duplo-cego do estudo}

Para avaliação da integridade do ensaio clínico, quanto à condição de estudo duplo-cego durante as 12 semanas de acompanhamento, 0 pesquisador que realizou o atendimento médico e, também, os pacientes eleitos para o estudo foram avaliados quanto à impressão que tinham da medicação que estava sendo usada em cada caso.

O pesquisador, que tinha como função o atendimento médico e a coleta dos resultados, desconhecia o grupo a que o paciente pertencia (ondansetrona ou placebo). Durante o acompanhamento dos pacientes, ele deixava anotado a sua impressão quanto a que medicamento cada paciente estaria recebendo.

Os participantes eleitos para a pesquisa sabiam sobre a possibilidade de estarem usando placebo ou ondansetrona durante seu tratamento. Eles eram questionados desde o momento da randomização em qual grupo achavam que estariam alocados (placebo ou ondansetrona). Nos casos em que houvesse mudança da impressão no decorrer do tratamento, foi considerada apenas a última impressão para fins da integridade. 


\subsubsection{Critérios de inclusão e exclusão}

Os critérios de inclusão e exclusão foram elaborados conforme estudos prévios realizados em nosso grupo, que estão alinhados a outros estudos similares, respeitando os preceitos dos bons ensaios clínicos (Baltieri e De Andrade, 2004; Baltieri et al., 2009a; Jonhson et al., 2002).

\subsubsection{Critérios de inclusão}

- Consentir e preencher o termo de consentimento pósinformação;

- Sexo masculino;

- Ter idade entre 18 e 60 anos;

- Ter o diagnóstico de síndrome de dependência do álcool, segundo os critérios da CID-10 (Classificação Internacional de Doenças da OMS, em sua décima edição);

- Manifestar o desejo de parar de beber.

\subsubsection{Critérios de exclusão}

- Presença de doenças psiquiátricas, que necessitassem de tratamento que não a dependência de álcool e nicotina;

- Ter idade menor que 18 anos ou maior que 60 anos, completos;

- Analfabetismo ou incapacidade de compreender as informações contidas no termo de consentimento pós-informação;

- Hipersensibilidade conhecida a ondansetrona;

- Exposição a qualquer outro fármaco ou dispositivo experimental nos 6 meses anteriores à avaliação inicial;

- Transtornos mentais graves (por exemplo, transtornos psicóticos), que necessitassem de internação psiquiátrica ou 
prescrição de psicofármacos (por exemplo, ansiolíticos, antidepressivos);

- História ou evidência de doença clínica significante (como insuficiência hepática, cardíaca e renal, epilepsia, hipertensão arterial sistêmica e diabete melito de difícil controle.);

- Uso de outras substâncias psicoativas nos últimos 30 dias, tais como: cocaína, anfetaminas, canábis, excetuando nicotina.

\subsection{Instrumentos usados no estudo}

\subsubsection{AUDIT (Alcohol Use Disorders Identification Test)}

O instrumento foi desenvolvido por Babor, com objetivo de detecção de consumos abusivos de álcool (Babor et al., 1992b). A versão do questionário foi traduzida para o português (Mendez, 1999). Ele é composto de 10 perguntas, que avaliam retrospectivamente os últimos 12 meses (anexo G). Os três primeiros itens aferem o volume e frequência do consumo do álcool. As questões recebem pontuação de 0 a 4 pontos, o total do teste pode ser pontuado de 0 a 40 pontos; valores maiores que 8 indicam a necessidade de intervenção (Babor et al., 1992b).

\subsubsection{SADD (Short Alcohol Dependence Data)}

O questionário foi desenvolvido por Raistrick et al. (1983), com objetivo de avaliar a gravidade de dependentes de álcool. Essa escala foi padronizada para o uso em nosso país (Jorge e Mansur, 1986). Consiste em um questionário com 15 itens, com quatro respostas (pontuação de 0 a 3), podendo ter pontuação total de 0 a 45 pontos (anexo $F$ ). A gravidade é dada por pontuações elevadas (0-9 é leve; 10-19 é moderada; 20-45 é grave). 
4.4.3 CIWA-Ar (Clinical Institute Withdrawal Assessment for Alcohol revised)

A escala foi elaborada para mensurar a intensidade de sintomas de abstinência ao álcool, podendo servir de referência para indicar necessidade de medicação (Shaw et al., 1981). Permite acompanhar a resposta terapêutica da síndrome de abstinência do álcool ao tratamento instituído em casos graves.

Oito anos após ter sido desenvolvida, a escala passou por uma revisão (Sullivan et al., 1989). A CIWA-Ar (anexo H) tem sido usada para avaliar a gravidade da síndrome de abstinência ao álcool, a evolução dos sintomas de abstinência, como também, para comparar os sintomas de abstinência entre grupos nos ensaios clínicos farmacológicos para o tratamento do alcoolismo (Browe et al., 2008; Johnson et al., 2000c; Reoux e Miller, 2000).

$\mathrm{Na}$ escala são avaliados dez itens (ansiedade, agitação, distúrbios auditivos, cefaleia, náusea/vômito, distúrbios táteis, tremores, sudorese, distúrbios visuais e orientação). Cada item tem pontuação que vai de zero a sete, com exceção do item sobre alterações da orientação, no qual a pontuação vai de zero a quatro. A pontuação total pode ir de 0 a 64 pontos. Índices menores que 10 indicam casos leves, sem necessidade de medicação para a síndrome de abstinência. Pontuação, maior que 15, está associada a quadro potencialmente grave, que necessitam de medicação apropriada (Puz e Stokes, 2005).

\subsubsection{ESA (Escala de Seguimento para Alcoolistas)}

Esta escala foi desenvolvida para mensurar objetivamente a evolução dos alcoolistas durante o tratamento (anexo I). Para graduar o impacto do problema decorrente do alcoolismo, foram escolhidas áreas que são diretamente afetas pelo consumo de bebida, e, para aumentar a confiabilidade, foi acrescido de um marcador biológico dotado de elevada sensibilidade. 
As quatro áreas escolhidas têm pesos diferentes para cada uma: consumo de álcool (peso 4); situação profissional (peso 3); relação familiar (peso 2); lazer (peso 1). O quinto item usa um marcador biológico, a dosagem do nível sérico da gama-glutamil transpeptidase. Nesta escala, cada área recebe uma nota de um a cinco, sendo que quanto menor a nota, pior a avaliação (Andrade et al., 1988).

\subsubsection{OCDS (Obsessive Compulsive Drinking Scale)}

O instrumento OCDS foi desenvolvido para mensurar a "fissura" pelo consumo do álcool em pacientes dependentes desta substância, a partir de escala para a avaliação de distúrbios obsessivos compulsivos (Anton et al., 1995). Essa escala (anexo K) foi validada e tem sido usada em pesquisas

clinicas (Anton et al., 1996). Foi traduzida para o português e tem sido usada em vários estudos desenvolvidos em nosso meio, apesar de ainda não ter sido validada (Nakamura-Palacios, 2002).

\subsubsection{Hamilton-21 (Escala de depressão Hamilton com 21 itens)}

Foi desenvolvida há mais de 50 anos, mas persiste ainda hoje como a escala para depressão mais usada no mundo. Tem sido usada para avaliar e quantificar sintomas depressivos, não tendo valor reconhecido para o diagnóstico de depressão (Hamilton, 1960).

A escala possui 21 itens, mas existem variações que aumentam para 24 itens (desamparo, desesperança e desvalia) ou diminuem para 17 itens (retirando a variação diurna do humor, desrealização, sintomas paranoides e obsessivos). Ela é um instrumento que considera os dados da entrevista com o paciente (anexo J), mas também outras fontes (por exemplo: informação da família e enfermagem). Não existem pontos de cortes claros, mas valores menores que 9 pontos indicam sintomatologia leve; entre 10 e 17, moderada e maiores que 18 pontos, grave (Moreno e Moreno, 1998). 
4.4.7 Escala de efeitos colaterais UKU (Ugvald for Kliniske Undersgelser)

A Ugvald for Kliniske Undersgelser (UKU) é escala usada em vários estudos para avaliar a tolerância e a incidência de efeitos colaterais, tendo sido desenvolvida há mais de 20 anos (Lingjaerde et al., 1987).

O instrumento é dividido em quatro sessões, sendo três específicas (com sintomas psiquiátricos, neurológicos e autonômicos, com 8, 8 e 10 itens em cada seção, respectivamente) e a última com 23 sintomas diversos. Cada item (sintoma ou sinal) é avaliado quanto à intensidade (com pontuação de 0 a 3) e relação causal entre o sintoma e uso da medicação (improvável, possível e provável). Essa escala permite a avaliação de múltiplos sintomas, ao mesmo tempo, nos sujeitos da pesquisa. 


\subsection{Formulação de tipologia para alcoolistas e retenção no tratamento}

Após o término do ensaio clínico com a ondansetrona, o banco de dados desta pesquisa foi combinado aos bancos de dados de dois outros estudos realizados no PROGREA entre 2000 e 2008 (figura 5). O primeiro destes com acamprosato e placebo (Baltieri e De Andrade, 2004), o segundo deles comparando topiramato, naltrexona e placebo (Baltieri et al., 2008). A combinação dos bancos de dados foi possível porque todos os ensaios clínicos foram estudos randomizados, duplo-cegos e placebo controlado, com 12 semanas de acompanhamento. Os três estudos foram realizados para detectar a eficácia de medicamentos ativos em reduzir o consumo de álcool, promovendo abstinência e diminuindo a "fissura" pelo álcool de pacientes ambulatoriais.

O primeiro desses ensaios, previamente desenvolvido no PROGREA, comparou o acamprosato $(1.999 \mathrm{mg} / \mathrm{dia})$ com placebo. Foi realizado entre 2000 e 2002, participando dele 75 indivíduos, dos quais 40 foram medicados com acamprosato e $35 \mathrm{com}$ placebo (Baltieri e De Andrade, 2004). O segundo desses ensaios, comparando topiramato $(300 \mathrm{mg} / \mathrm{dia})$, naltrexona (50mg/dia) e placebo, foi realizado entre 2004 e 2007 (Baltieri et al., 2008). Todos os ensaios clínicos foram desenvolvidos no ambiente com a mesma estrutura clínica, usando as mesmas abordagens comportamentais e respeitando os preceitos dos bons estudos duplo-cegos.

\subsubsection{Participantes atendidos nos três ensaios}

Todos os pacientes eram do sexo masculino, com idade entre 18 e 60 anos, com diagnóstico de síndrome de dependência do álcool pela classificação internacional de doença (CID-10) e procuraram tratamento ambulatorial para dependência de álcool no setor de assistência do PROGREA.

Os critérios de exclusão foram os mesmos em todos os ensaios clínicos: idade menor que 18 anos ou mais de 60 anos completos; presença 
de abuso ou dependência de outras drogas, exceto nicotina; presença de doenças clínicas importantes, por exemplo, insuficiência cardíaca, diabetes descompensada e cirrose hepática; histórico de tratamento prévio para dependência de álcool nos seis meses anteriores à randomização; presença de transtorno mental relevante, que demandasse tratamento; uso atual de medicamento psicotrópico; incapacidade de ler e assinar o termo de consentimento pós-informado; por fim, história clínica de retardo mental que possa dificultar a interpretação do termo de consentimento pós-informado.

Em todos os estudos, os pacientes foram incentivados a participar do AA, mas a sua participação no grupo de mútua ajuda não era condição obrigatória para continuar no tratamento.

A amostra foi constituída de 332 homens com idade entre 18 e 60 anos. Aproximadamente $56 \%$ dos participantes eram casados, $63 \%$ da raça branca, $57 \%$ não haviam completado o segundo grau. A renda mensal dos participantes era de $R \$ 969,00(\mathrm{DP}=989,96)$ e $226(68 \%)$ dos sujeitos da pesquisa eram tabagistas. 
Figura 5. Fluxograma dos pacientes que participaram dos estudos: acamprosato versus placebo e topiramato e naltrexona versus placebo.

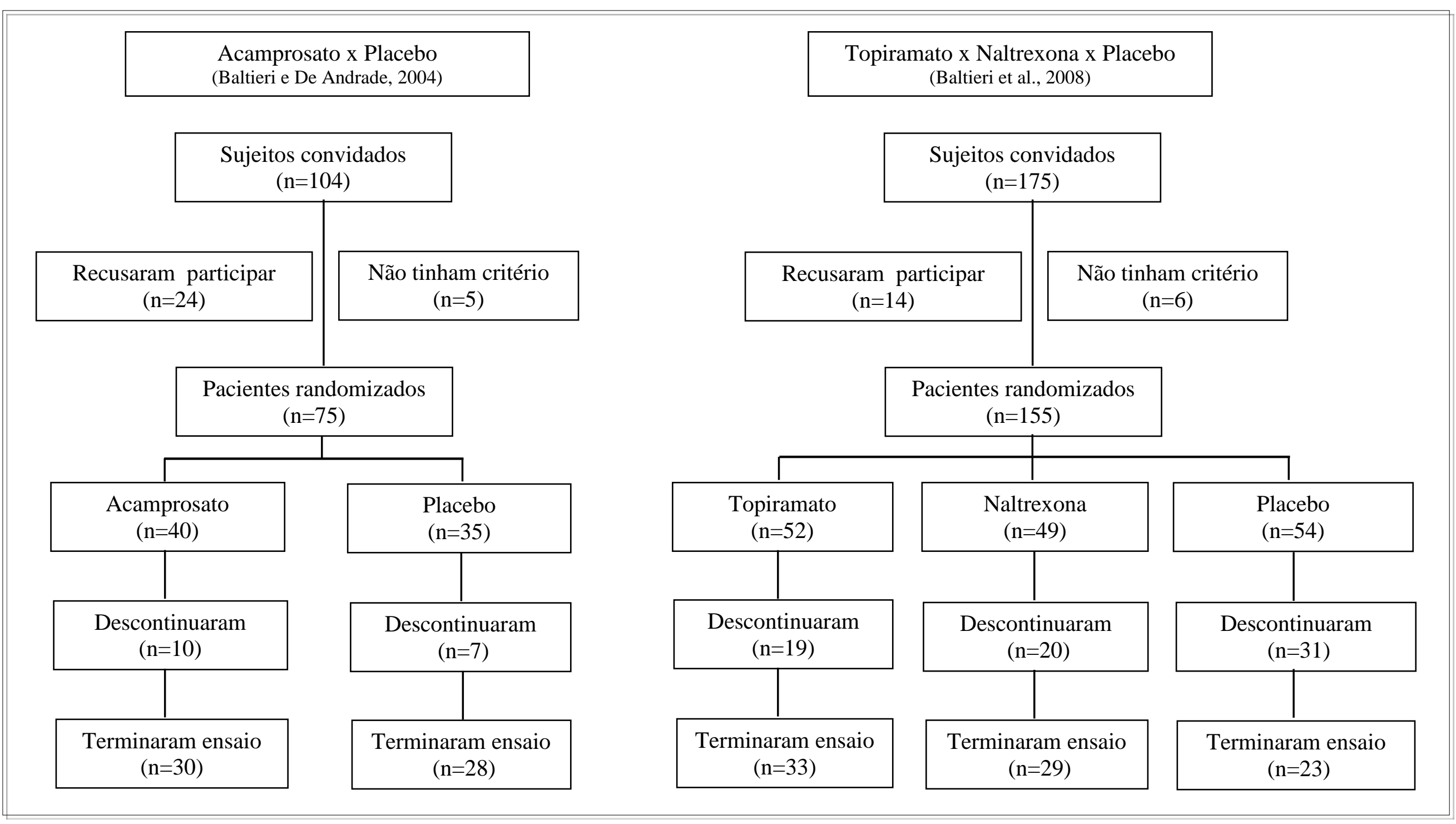




\subsubsection{Acompanhamento dos pacientes nos três ensaios}

Em todos os estudos, os participantes passaram por um período de uma a duas semanas de desintoxicação. No primeiro encontro, foi realizada uma história clínica detalhada e exame clínico minucioso dos pacientes eleitos para participar dos ensaios. A coleta de dados sociodemográficos, histórico de uso de álcool e outras drogas na vida, história familiar de problemas com álcool e drogas, consumo diário de álcool em gramas, idade de início do consumo de álcool, idade de início dos problemas com o consumo de álcool e duração dos problemas com a bebida foram realizados usando o "protocolo comum do PROGREA", uma entrevista semiestruturada rotineiramente usada em pesquisas realizadas no PROGREA.

Foi usada a idade de início dos problemas com o consumo de álcool para categorizar os pacientes em bebedores de início precoce (bebedor precoce) e bebedores de início tardio (bebedor tardio), tipologia de alcoolista usada em outros ensaios clínicos (Johnson et al., 2007; Ait-daoud et al., 2001; Sellers et al., 1994). Os bebedores precoces tiveram os problemas decorrentes do consumo do álcool iniciados antes dos 25 anos de idade. Já os bebedores tardios tiveram seus problemas iniciados após os 25 anos de idade completos (Johnson et al., 2000b).

Todos os participantes foram avaliados quanto à gravidade do consumo do álcool com a escala SADD e intensidade dos sintomas depressivos com a Hamilton-21, na primeira entrevista. A avaliação da "fissura" pelo álcool, feita com a OCDS, não foi realizada no ensaio com acamprosato (Baltieri e De Andrade, 2004). A avaliação de efeitos adversos foi realizada pela UKU, em todos os encontros após a primeira entrevista.

A importância da história familiar do alcoolismo foi testada. Para evitar uma categorização da história familiar como "ter" ou "não ter" antecedentes familiares de dependentes de álcool, foi utilizado uma escala de ponderação. Assim para familiares de primeiro grau foi atribuída pontuação de 0,5 e para familiares de segundo grau, a pontuação de 0,25. A busca de alcoolismo familiar foi feita minuciosamente através de questionamento ao paciente e a seus familiares sobre pessoas na família que apresentassem história atual e pregressa de problemas com o consumo de álcool. 
Os pacientes foram questionados sobre seu consumo médio diário de cerveja, destilados e vinho, como a duração e a frequência de uso diário (manhã, tarde e noite). Os bebedores de cerveja podem ser definidos como aqueles que consomem mais cerveja do que destilado ou vinho, definição também usada para os bebedores de vinho e destilado. Para obter uma classificação mais precisa, foi definido como bebida predominante (destilado, cerveja ou vinho), aquela que representasse dois terços ou mais do consumo do álcool diário, conforme estudos prévios (Baltieri et al., 2009b).

Semanalmente os sujeitos foram questionados sobre sua participação no AA. Foi considerado aderente aquele que tivesse participado pelo menos uma vez por semana.

\subsubsection{Procedimentos}

Todos os pacientes passaram pelo período de desintoxicação antes de iniciarem os ensaios clínicos duplo-cegos. Este período foi realizado ambulatoriamente e os pacientes que tiveram manifestação de sintomas de abstinência foram medicados, segundo protocolo do PROGREA, com até lorazepam $6 \mathrm{mg} / \mathrm{dia}$, dependendo da intensidade dos sintomas de abstinência, acido fólico e vitamina $B_{1} 300 \mathrm{mg} / \mathrm{dia}$. Exames laboratoriais, incluindo hemograma e função hepática, foram realizados nesse período. Os pacientes incluídos nesses três estudos tiveram sintomas de abstinência de leve a moderada intensidade, o que permitiu um tratamento ambulatorial.

Em cada encontro, todos os participantes receberam intervenções cognitivo-comportamentais breves, manualizadas e padronizadas em nosso serviço. O objetivo dessas intervenções foi aumentar as habilidades pessoais de lidar com situações de alto risco, que pudessem precipitar uma recaída. Durante o acompanhamento, os pacientes eram orientados a monitorar situações diárias boas e ruins. Essas situações foram discutidas com seus médicos e, quando possível, relacionadas ao comportamento adicto. Os seguintes tópicos foram padronizados e trabalhados no decorrer do tratamento com cada paciente: gerenciamento de humor depressivo; assertividade, habilidade de recusar a bebida, melhoria da rede de apoio social e prevenção de recaída. 
Em cada estudo as cápsulas usadas foram fabricadas pela Unidade de Farmácia do Instituto de Psiquiatria do Hospital das Clinicas da Faculdade de Medicina da Universidade de São Paulo com a finalidade de terem a mesma aparência, a fim de preservar a condição de um estudo duplo-cego.

Nesta análise, a retenção no tratamento foi usada como resultado desejado. As taxas de desligamento foram calculadas a partir do início do uso das medicações avaliadas. Três razões foram consideradas para 0 desligamento: recusa em continuar (o paciente deseja parar este tratamento e tentar outra possibilidade terapêutica, como por exemplo, psicoterapia apenas); violação de protocolo (o paciente usa outra medicação farmacologicamente ativa, que possa interferir no resultado, ou deixa de usar a medicação prescrita); por fim, perda de seguimento (o paciente desistiu do acompanhamento e não manifesta qualquer desejo de fazer outro tipo de tratamento). Os participantes que permaneceram no estudo por 12 semanas foram considerados como aderentes. Os sujeitos que não completaram as 12 semanas dos estudos foram considerados como abandonos do tratamento. 


\subsection{Variáveis clínicas relacionadas com a adesão ao tratamento}

Com o intuito de identificar características relacionadas aos pacientes, que possam prever o maior risco de abandono ao tratamento, foi realizada a avaliação de todas as variáveis disponíveis. Para esta análise foram excluidos os participantes do estudo com acamprosato (Baltieri e De Andrade, 2004), pois nesta pesquisa não foi realizada avaliação do grau de "fissura" pelo álcool (OCDS). Foram mantidos os participantes do ensaio com ondansetrona e placebo (descrito anteriormente) e do ensaio com topiramato, naltrexona e placebo (Baltieri et al., 2008), conforme ilustrado na figura 6.

Todos os participantes incluídos na análise tiveram as variáveis coletadas no início do acompanhamento, a saber: raça, idade, estado civil, sintomatologia depressiva medida pela Hamilton-21, renda mensal, estado civil, idade atual, idade em que iniciaram consumo de bebida aloólica, idade em que iníciaram os problemas com o consumo do álcool, o consumo diário de álcool antes da medicação, histórico de tratamentos prévios para o alcoolismo, atendimento prévio no AA, bebida preferencial, gravidade da dependência do álcool (medida pela SADD), e "fissura" pelo álcool (mensurada pela OCDS).

A variável "carreira de consumo do álcool" foi criada a partir da diferença entre idade em que o paciente iníciou o consumo de álcool e a idade que ele tinha no início dos estudos. Essa variável representa o tempo de exposição do participante à bebida etílica. A variável "tempo de problemas com álcool" foi calculada pela diferença entre a idade em que o paciente iníciou os problemas com o consumo do álcool e a idade que ele apresentava no início do tratamento. Essa variável computada representa o intervalo de tempo que o dependente de álcool vem apresentando problemas com a bebida.

A definição de aderência ao tratamento, usada nesta análise, foi a mesma citada anteriormente, ou seja, o participante deveria completar as doze semanas de tratamento. Os motivos para descontinuidade do estudo foram mantidos, ou seja, as três razões possíveis foram: recusa em continuar, violação de protocolo e perda de seguimento. 
Figura 6. Fluxograma dos participantes selecionados para avaliação das variaveis, relacionadas aos pacientes, capazes de prever a aderência no tratamento.

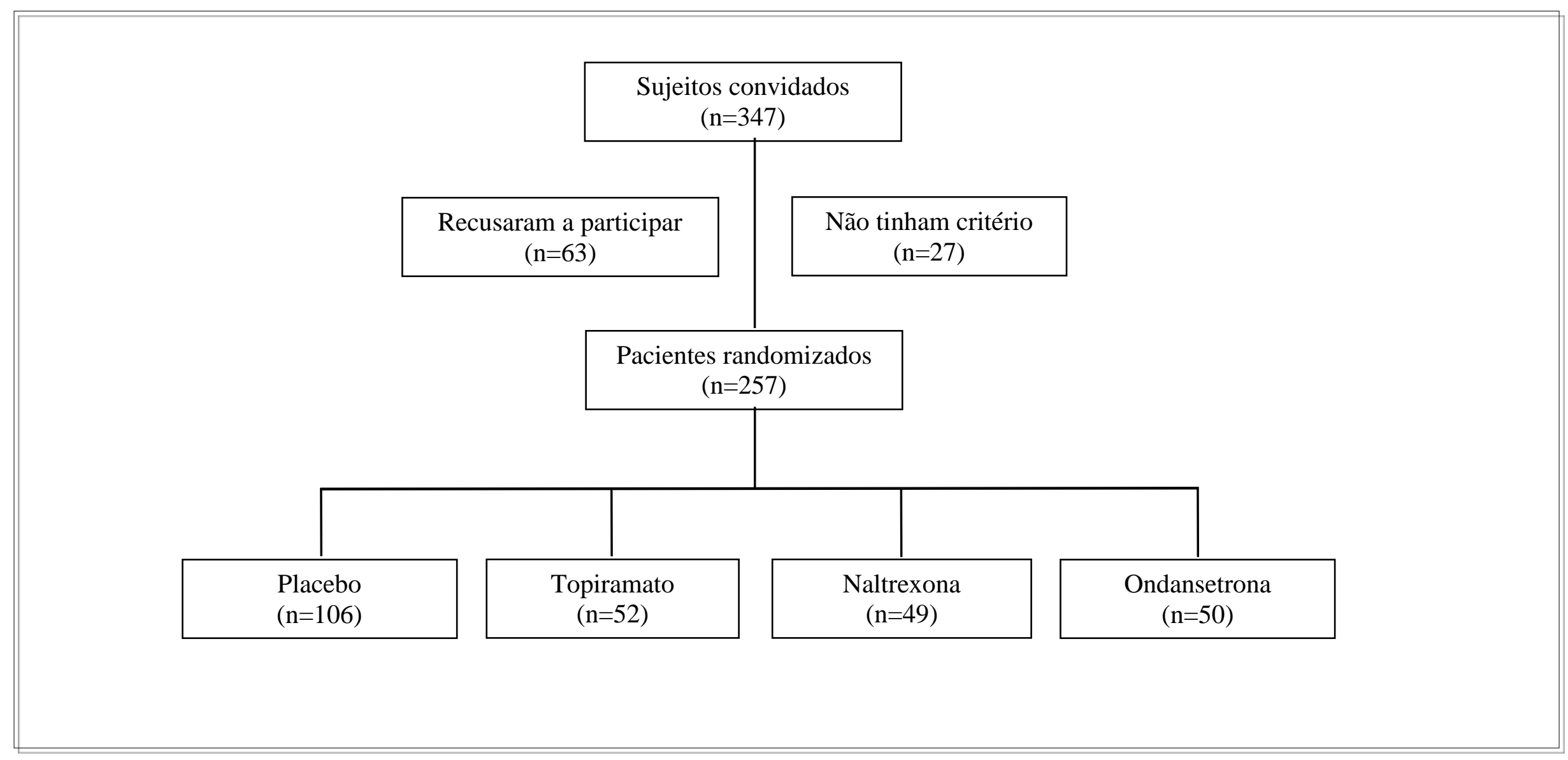




\subsection{Considerações éticas}

No momento em que os pacientes passavam pela primeira entrevista no PROGREA eles eram informados da pesquisa. Os interessados em participar do ensaio tiveram o seu consentimento solicitado por escrito, de acordo com as normas éticas e regulamentares vigentes no Hospital das Clínicas da Faculdade de Medicina da Universidade de São Paulo (anexo B). Todos os pacientes receberam a informação de que a escolha por participar do estudo era voluntária e, se não a fizessem, poderiam ser atendidos pelo fluxo usual do PROGREA. Aos que optassem pela pesquisa, foi assegurado que poderiam mudar sua escolha no decorrer do tratamento, sem qualquer ônus.

A realização desta pesquisa $\left(n^{\circ} 0356 / 07\right)$ foi aprovada pela Comissão para Análise de Projetos em Pesquisa - CAPPesq - órgão do Hospital das Clínicas da Faculdade de Medicina da Universidade de São Paulo (Anexo A).

\subsection{Análise estatística}

Os dados da pesquisa foram processados, utilizando-se os programas estatísticos SPSS 18.0, G*Power 3 e Stata 7.0. Os grupos foram descritos em suas características sociodemográficas e psicométricas, mediante a média e o desvio padrão para variáveis contínuas e percentuais, para as variáveis categóricas. Os resultados das escalas utilizadas foram organizados em gráficos e tabelas e analisados estatisticamente. O nível de significância adotado foi $5 \%$.

Para as variáveis qualitativas ou categóricas, foram utilizados o teste Qui-Quadrado de Pearson e o teste exato de Fisher, este último aplicado quando uma das "caselas" apresentou valor menor do que cinco. Nas análises com mais de dois grupos, quando necessário, o fator de Correção de Yates foi empregado, a fim de detectar diferenças entre os subgrupos. 
Para as variáveis contínuas ou quantitativas, o teste de Kruskal-Wallis ou a Análise de Variância foram utilizados, já que foi necessário analisar mais de dois grupos. A eleição desses testes obedeceu aos critérios relacionados à utilização de testes paramétricos ou não paramétricos. $A$ Múltipla Análise de Variância (MANOVA) foi usada, já que o presente projeto avaliou múltiplas variáveis dependentes.

Técnicas de regressão múltipla (logística) também foram utilizadas, objetivando determinar até que ponto determinadas variáveis explicativas significativas nas análises unifatoriais conseguiam prever o resultado da variável dependente, após ajustamento.

A Análise de Sobrevida (Kaplan Meier) foi utilizada para determinar qual dos grupos (ondansetrona ou placebo) apresentou maior tempo de abstinência, durante o tratamento proposto e, também o tempo para a primeira recaída pesada.

Para avaliar a eficácia da ondansetrona durante as 12 semanas pesquisadas, foi usado o teste de medidas repetidas "equação estimativa generalizada" - GEE, do inglês, "Generalized Estimating Equation" (Hanley et al., 2003). Esse teste é capaz de identificar a influência da medicação durante as 12 semanas em que foi avaliado o consumo de álcool.

Para a análise do consumo de álcool durante o acompanhamento foram usados apenas os dados completos, obtidos a partir dos pacientes que terminaram o estudo. Foi também, realizada análise dos dados brutos (completos e incompletos) para identificar se os desligamentos dos pacientes ocorreram ao acaso, ou, se estiveram associados a variáveis preditoras da descontinuação do tratamento. Com a determinação de quais variáveis estavam associadas com o abandono do tratamento, foi realizada imputação múltipla dos dados faltantes, tendo como base essas variáveis preditoras de abandono. Com os dados já imputados, foi realizada nova análise GEE, para avaliar a eficácia da medicação testada.

A premissa teórica mais importante para o uso da análise de cluster neste trabalho é o conceito de 'tipos' de alcoolistas. Cada tipo representaria 
uma síndrome que inclui um conjunto de características muito próximas. Para a elaboração da tipologia de alcoolistas foi usada a análise de cluster tipo "K-means". Este método tenta agrupar os sujeitos com características próximas. No processo de formulação da tipologia, o número de clusters foi determinado a partir do "índice de silhueta", valor este que está relacionado diretamente com a maior capacidade de distinção entre os grupos. Para a criação da tipologia, foram usadas as variáveis: o histórico de alcoolismo familiar, a idade de início dos problemas com álcool, a gravidade da dependência do álcool (SADD) e a intensidade dos sintomas depressivos (Hamilton-21). Essas variáveis foram escolhidas porque já tinham sido usadas em estudos tipológicos prévios (Hauser e Rybakowski, 1997). 


\section{RESULTADOS}

\subsection{Ensaio clínico com a ondansetrona}

\subsubsection{Dados sociodemográficos e clínicos}

Participaram da entrevista 172 pessoas. Após serem informados, 49 sujeitos se recusaram a participar do estudo, seguindo o fluxo de tratamento usual para alcoolismo do PROGREA. Dos 123 interessados em participar do ensaio, 21 deles não apresentavam critérios de eleição da pesquisa sendo encaminhados para tratamento usual do grupo (figura 7).

Os 102 pacientes restantes foram distribuídos aleatoriamente em dois grupos diferentes, sendo que $50(49,02 \%)$ pacientes ficaram no grupo que recebeu ondansetrona e 52 (50,98\%) no grupo que recebeu placebo.

A comparação entre os grupos mostra que a idade média dos participantes ao iniciar o estudo era, aproximada, de 44 anos no grupo ondansetrona e 42 anos no grupo placebo. A idade da primeira experiência com álcool foi de 15 anos em ambos os grupos e o início dos problemas com o consumo dessa substância foi de 30 anos no grupo ondansetrona versus 29 anos no grupo placebo, entretanto essa diferença não foi significativa. Também, não houve diferença estatística entre a raça, estado civil e escolaridade. Entre os grupos não houve diferença entre a renda mensal de ambos os grupos que era de 2,9 salários mínimos (tabela 8).

Os alcoolistas participantes do ensaio clínico, em sua maioria, eram tabagistas $(63,7 \%)$, já haviam feito algum tipo de tratamento previamente $(55,8 \%)$, ainda, o número de cigarros e o histórico de tratamento prévio para o alcoolismo prévio, nos grupos ondansetrona e placebo não foram diferentes.

Entre os participantes a preferência por consumir bebidas destiladas era marcante (73,5\%). O uso prévio de outra droga, além do tabaco e álcool, foi relatado por $37,3 \%$ dos pacientes. Não houve diferença estatística 
significante entre os grupos nas características clínicas citadas acima. A história familiar, também, foi semelhante em ambos os grupos.

Os pacientes que receberam ondansetrona consumiam mais álcool que os do grupo placebo (300,2 gramas versus 285,1 gramas), mas esta diferença não foi significante do ponto de vista estatístico.

Não houve diferença estatisticamente significante entre os dois grupos no que diz respeito aos níveis séricos de gama glutamil transpeptidase (GGT), alanina aminotransferase (ALT), aspartado aminotransferase (AST) e volume corpuscular médio (VCM). Nota-se que em ambos os grupos os níveis de GGT apontam para ingestão pesada de álcool e lesão hepática aguda, contudo, os níveis de bilirrubina total e indireta, mais a atividade de protombina (INR), demonstram uma função hepática preservada em ambos os grupos.

Os testes psicométricos aplicados mostraram que não existiu diferença significativa entre os participantes dos grupos, no que se refere à gravidade do alcoolismo (SADD e AUDIT), "fissura" pelo álcool (OCDS), sintomas de humor (HAMILTON-21), escala de seguimento de alcoolistas (ESA) e intensidade dos sintomas de abstinência ao álcool (CIWA-AR). 
Figura 7. Fluxograma com os participantes do ensaio com ondansetrona e placebo.

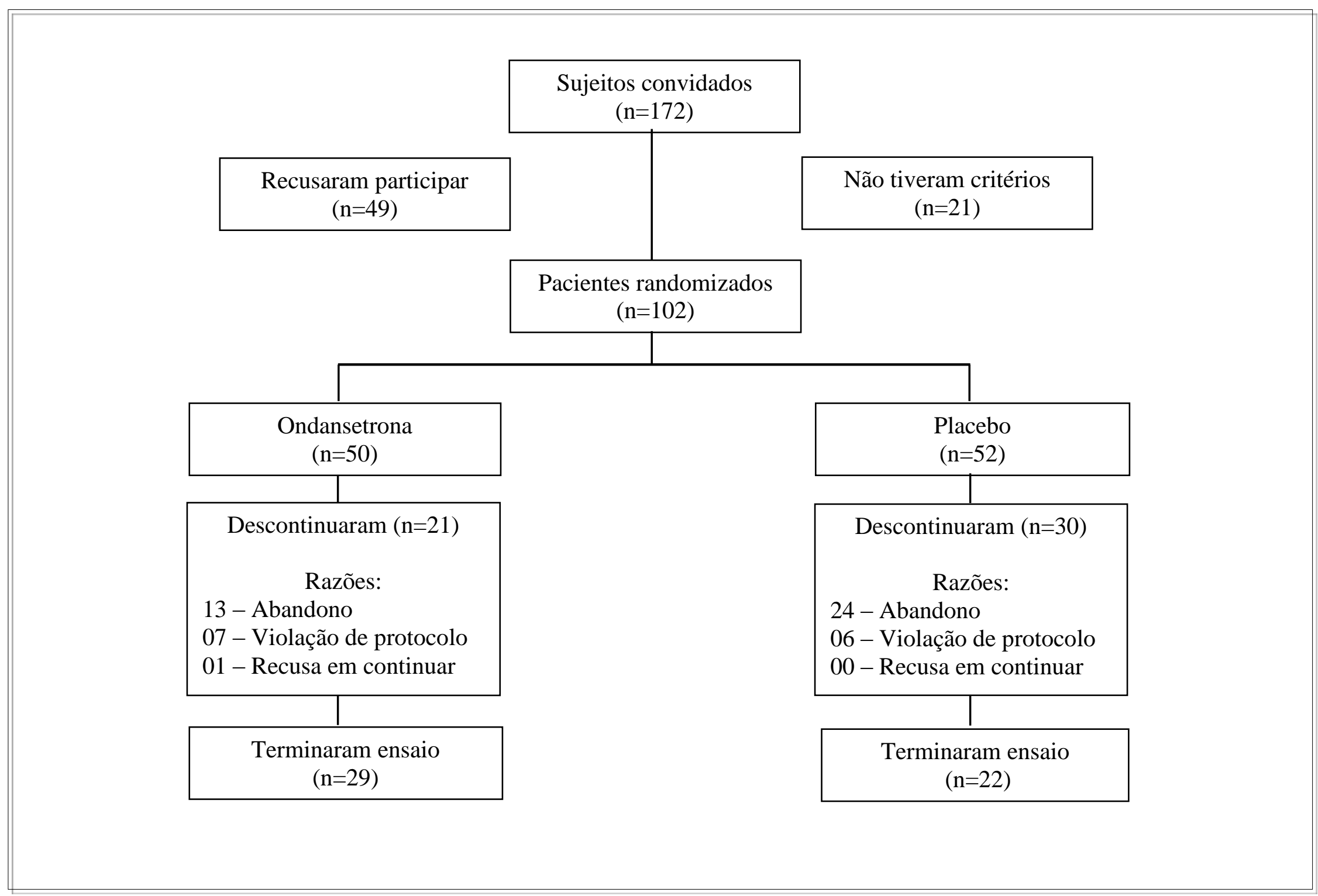


Tabela 8. Características iniciais dos grupos ondansetrona e placebo.

\begin{tabular}{|c|c|c|c|}
\hline Características & Placebo $(\mathbf{n}=\mathbf{5 2})$ & Ondansetrona $(\mathbf{n}=\mathbf{5 0})$ & 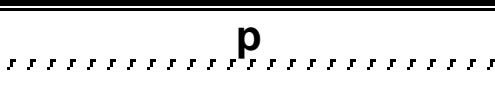 \\
\hline Idade, média (DP) & $42,19(9,02)$ & $43,66(10,14)$ & $t=-0,77,100 d f, p=0,44$ \\
\hline $\begin{array}{l}\text { Estado Civil, n (\%) } \\
\text { Casado } \\
\text { Solteiro } \\
\text { Separado / Viúvo }\end{array}$ & $\begin{aligned} & 37(71,15) \\
& 4(7,69) \\
& 11(21,16) \\
&\end{aligned}$ & $\begin{array}{l}27(54) \\
11(22) \\
12(24) \\
\end{array}$ & $\chi^{2}=4,83,2 \mathrm{df}, \mathrm{p}=0,09$ \\
\hline Raça, n (\%) & $\begin{array}{l}14(26,92) \\
11(21,16) \\
27(51,92) \\
\end{array}$ & $\begin{array}{l}20(40) \\
11(22) \\
19(38) \\
\end{array}$ & $\chi^{2}=2,41,2 d f, p=0,30$ \\
\hline $\begin{array}{l}\text { Educação, } \mathrm{n}(\%) \\
12^{\circ} \text { anos ou menos de estudo } \\
13^{\circ} \text { anos ou mais de estudo }\end{array}$ & $\begin{array}{l}32(61,54) \\
20(38,46)\end{array}$ & $\begin{array}{l}24(48) \\
26(52)\end{array}$ & $\chi^{2}=1,89,1 \mathrm{df}, \mathrm{p}=0,17$ \\
\hline $\begin{array}{l}\text { Quantida de etanol por dia (em gramas), } \\
\text { média (DP)* }\end{array}$ & $285,07(171,42)$ & $300,15(200,45)$ & $t=-0,41,100 d f, p=0,68$ \\
\hline $\begin{array}{l}\text { Anos desde o início dos problemas com uso } \\
\text { do álcool, média (DP) }\end{array}$ & $13,11(8,41)$ & $14,06(11,33)$ & $t=-0,48,100 d f, p=0,63$ \\
\hline Alcoolistas de início precoce, n (\%) & $25(48,06)$ & $25(50)$ & $\chi^{2}=0,04,1 d f, p=0,85$ \\
\hline Cigarros fumados por dia, média (DP) & $9,52(12,48)$ & $11,10(10,73)$ & $t=-0,68,100 d f, p=0,49$ \\
\hline História familiar de alcoolismo, n (\%) & $42(80,77)$ & $36(72)$ & $\chi^{2}=1,09,1 d f, p=0,30$ \\
\hline
\end{tabular}




\section{Características}

Tratamento prévio para alcoólismo, n (\%)

Renda mensal (em Reais), média (DP)

GGT sérico, U/L; média (DP)

(Valor de referencia 8-61)

\begin{tabular}{|c|c|c|c|}
\hline $\begin{array}{l}\text { ALT sérico, U/L; média (DP) } \\
\text { (Valor de referencia < } 41 \text { ) }\end{array}$ & $41,40(32,55)$ & $39,18(35,29)$ & $t=0,33,100 d f, p=0,74$ \\
\hline $\begin{array}{l}\text { AST sérico, U/L; média (DP) } \\
\text { (Valor de referencia < 37) }\end{array}$ & $49,90(44,56)$ & $34,16(22,27)$ & $U=1140, p=0,67$ \\
\hline $\begin{array}{l}\text { VCM sérico, f/L; média (DP) } \\
\text { (Valor de referencia 80-100) }\end{array}$ & $94,09(6,94)$ & $93,90(8,43)$ & $t=0,13,100 d f, p=0,90$ \\
\hline $\begin{array}{l}\text { Bilirrubina Total, mg/dL; média (DP) } \\
\text { (Valor de referencia } 0.20-1.00)\end{array}$ & $0,61(0,29)$ & $0,56(0,30)$ & $t=1,47,100 d f, p=0,32$ \\
\hline $\begin{array}{l}\text { Bilirrubina Indireta, mg/dL; média (DP) } \\
\text { (Valor de referencia } 0.10-0.60)\end{array}$ & $0,48(0,41)$ & $0,37(0,22)$ & $t=1,55,100 d f, p=0,12$ \\
\hline $\begin{array}{l}\text { Protrombina/INR; média (DP) } \\
\text { (Valor de referencia 0.95-1.20) }\end{array}$ & $0,99(0,04)$ & $0,98(0,04)$ & $t=1,27,100 d f, p=0,21$ \\
\hline CIWA-AR, média (DP) & $13,83(8,93)$ & $13,08(7,97)$ & $t=0,44,100 d f, p=0,66$ \\
\hline SADD, média (DP) & $24,67(6,97)$ & $26,76(8,11)$ & $t=-1,39,100 d f, p=0,17$ \\
\hline
\end{tabular}

Placebo $(n=52) \quad$ Ondansetrona $(n=50)$

$\mathbf{p}_{I}$ $\chi^{2}=0,18,1 d f, p=0,67$ $1418,19(890,99) \quad 1479,01(1232,13) \quad t=-0,29,100 d f, p=0,77$ $255,75(446,91) \quad 147,88(269,46) \quad U=1198, p=0,49$ $28(53,85)$ $29(58)$ (2)

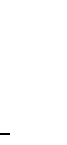




\section{Características}

Placebo $(n=52) \quad$ Ondansetrona $(n=50)$

p

\begin{tabular}{lccc} 
AUDIT, média (DP) & $28,42(5,91)$ & $29,90(6,11)$ & $\mathrm{t}=-1,24,100 \mathrm{df}, \mathrm{p}=0,22$ \\
\hline OCDS, média (DP) & $44,33(10,19)$ & $46(9,59)$ & $\mathrm{t}=-0,85,100, \mathrm{df}, \mathrm{p}=0,40$ \\
\hline ESA, média (DP) & $26,96(8,74)$ & $26,26(8,59)$ & $\mathrm{t}=0,41,100 \mathrm{df}, \mathrm{p}=0,68$ \\
\hline Hamilton-21, média (DP) & $9,56(5,49)$ & $8,46(5,02)$ & $\mathrm{t}=1,05,100 \mathrm{df}, \mathrm{p}=0,29$ \\
\hline \hline
\end{tabular}

Indica a media diária da pior semana de uso do álcool nos três meses anteriores ao início de estudo; ${ }^{\text {a }}$ Indica marcadores biologicos que foram mensurados e intrumentos que foram aplicados no inicio do ensaio clinic duplo-cego; GGT, gama glutamil transpeptidase; ALT, alanina aminotransferase; AST, aspartato aminotransferase; VCM, volume corpuscular médio; CIWA-AR, Clinical Institute Withdrawal Assessment; SADD, Short Alcohol Dependence Data; AUDIT, The Alcohol Use Disorders Identification Test; OCDS, Obsessive-Compulsive Drinking Scale; ESA, escala de seguimento de alcoolistas; Hamilton-21, escala de depressão Hamilton com 21 itens. 


\subsubsection{Marcadores biológicos de consumo do álcool}

Para análise dos marcadores biológicos foram incluídos apenas os dados dos pacientes que completaram os estudos (50\% dos indivíduos, 29 do grupo ondansetrona e 22 do placebo).

De uma maneira geral, houve a melhora nos marcadores, no decorrer das 12 semanas de seguimento. Entretanto, não houve influência do uso do placebo ou ondansetrona nesta melhora, pois as diferenças apresentadas não foram significantes (tabela 9). 
Tabela 9. Resultado dos marcadores biológicos dos pacientes que terminaram o estudo.

\begin{tabular}{|c|c|c|c|c|}
\hline \multirow[b]{2}{*}{$\begin{array}{l}\text { Início } \\
\text { In }\end{array}$} & GGT* $^{*}$ & $\mathrm{VCM}^{*}$ & $\mathrm{ALT}^{\star}$ & $\mathrm{AST}^{*}$ \\
\hline & $\ldots \ldots \ldots \ldots \ldots$ & 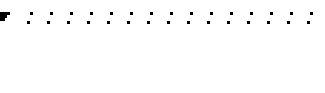 & 1 $: 2: z: z: z: z: z: z: z$ & m, mom \\
\hline $\begin{array}{r}\text { Ondansetrona } \\
(\mathrm{n}-29)\end{array}$ & $92,8(109,3)$ & $93,3(6,3)$ & $39,1(42,2)$ & $31,1(16,4)$ \\
\hline $\begin{array}{r}\text { Placebo } \\
(\mathrm{n}-22)\end{array}$ & $362,9(590,0)$ & $95,5(6,4)$ & $39,4(30,8)$ & $56,0(54,0)$ \\
\hline \multicolumn{5}{|l|}{ 6a semana } \\
\hline $\begin{array}{r}\text { Ondansetrona } \\
(\mathrm{n}-29)\end{array}$ & $39,7(22,6)$ & $90,7(6,0)$ & $26,5(13,7)$ & $24,7 \quad(6,3)$ \\
\hline $\begin{array}{r}\text { Placebo } \\
(n-22)\end{array}$ & $141,5(257,8)$ & $92,5(6,8)$ & $23,5(11,7)$ & $31,8(29,9)$ \\
\hline \multicolumn{5}{|l|}{$12^{\mathrm{a}}$ semana } \\
\hline $\begin{array}{r}\text { Ondansetrona } \\
(\mathrm{n}-29)\end{array}$ & $33,5(14,4)$ & $89,7(5,2)$ & $26,4(14,9)$ & $25,5(8,8)$ \\
\hline $\begin{array}{r}\text { Placebo } \\
(n-22)\end{array}$ & $152,2(263,6)$ & $91,4(7,8)$ & $23,5(11,7)$ & $39,2(36,1)$ \\
\hline $\mathrm{p}$ (Wald`s $\left.\chi^{2}, 2 \mathrm{df}\right)$ & $\chi^{2}=3,73, p=0,15$ & $\chi^{2}=0,07 p=0,97$ & $\chi^{2}=1,17 p=0,56$ & $\chi^{2}=3,73 p=0,15$ \\
\hline
\end{tabular}




\subsubsection{Tempo de abstinência continuada, tempo total de abstinência e tempo primeiro consumo pesado de álcool}

O tempo médio entre o início do tratamento e o primeiro consumo de bebida alcoólica foi de aproximadamente 55 dias, no grupo que recebeu ondansetrona e 41 dias no grupo medicado com placebo, essa diferença foi significante do ponto de vista estatístico $-\mathrm{t}=-2,08,100 \mathrm{df}, \mathrm{p}=0,041$ (tabela 10). A diferença entre as médias dos tempos totais de abstinência dos grupos, 60 dias no grupo ondansetrona e 50 dias no grupo placebo, não mostrou diferença estatística.

No grupo medicado com ondansetrona, o tempo médio para o primeiro beber pesado foi de 58 dias, enquanto, no grupo que recebeu placebo este tempo foi de 45 dias. Essa diferença foi estatisticamente significante ( $t=-2,099,100 d f, p=0,038)$.

Para a análise de sobrevida foi utilizado o princípio intenção de tratar (ITT, Intention to Treat Analisys). Todos os participantes que após a randomização fizeram uso de, ao menos, uma cápsula, foram incluídos na análise. A interrupção do tratamento foi interpretada como insucesso terapêutico, assim como a recaída. Na figura 8 , tem-se análise de sobrevida para primeira recaída, que mostrou uma diferença estatisticamente significativa entre a curva de sobrevida do grupo ondansetrona e a curva de sobrevida do grupo placebo ( $\chi^{2}=5,875,1 \mathrm{df}, p=0,015$; LogRank). Na figura 9 , tem-se a análise de sobrevida para o primeiro episódio de consumo pesado de álcool, que aponta uma diferença estatística significante entre a curva de sobrevida do grupo ondansetrona e a curva do grupo placebo $\left(\chi^{2}=6,403,1\right.$ df, $p=0,011$; LogRank). 
Tabela 10. Comparação entre as médias do tempo de abstinência continuada, tempo total de dias abstinentes e tempo para o primeiro consumo pesado do álcool, nos grupos ondansetrona e placebo, expresso em dias.

\begin{tabular}{|c|c|c|c|}
\hline & $\begin{array}{c}\text { Tempo Abstinência } \\
\text { continuada } \\
\text { (em dias) }\end{array}$ & $\begin{array}{c}\text { Tempo total Abstinente } \\
\text { (em dias) }\end{array}$ & $\begin{array}{c}\text { Tempo para o primeiro } \\
\text { consumo pesado do álcool } \\
\text { (em dias) }\end{array}$ \\
\hline $\begin{array}{l}(n=29) \\
\text { Ondansetrona } \mathrm{m}(\mathrm{DP})\end{array}$ & $54,7(33,8)$ & $60,3(30,9)$ & $58,4(30,7)$ \\
\hline \multirow[t]{2}{*}{$\begin{array}{l}\text { Placebo m(DP) } \\
(n=22)\end{array}$} & $40,9(34,2)$ & $49,8(32,3)$ & $45,4(31,4)$ \\
\hline & $t=-2,075,100 d f, p=0,041$ & $t=-1,680,100 d f, p=0,304$ & $t=-2,099,100 d f, p=0,038$ \\
\hline
\end{tabular}


Figura 8. Curva de sobrevida de Kaplan-Meier, para primeiro consumo de álcool, nos grupos placebo e ondansetrona.

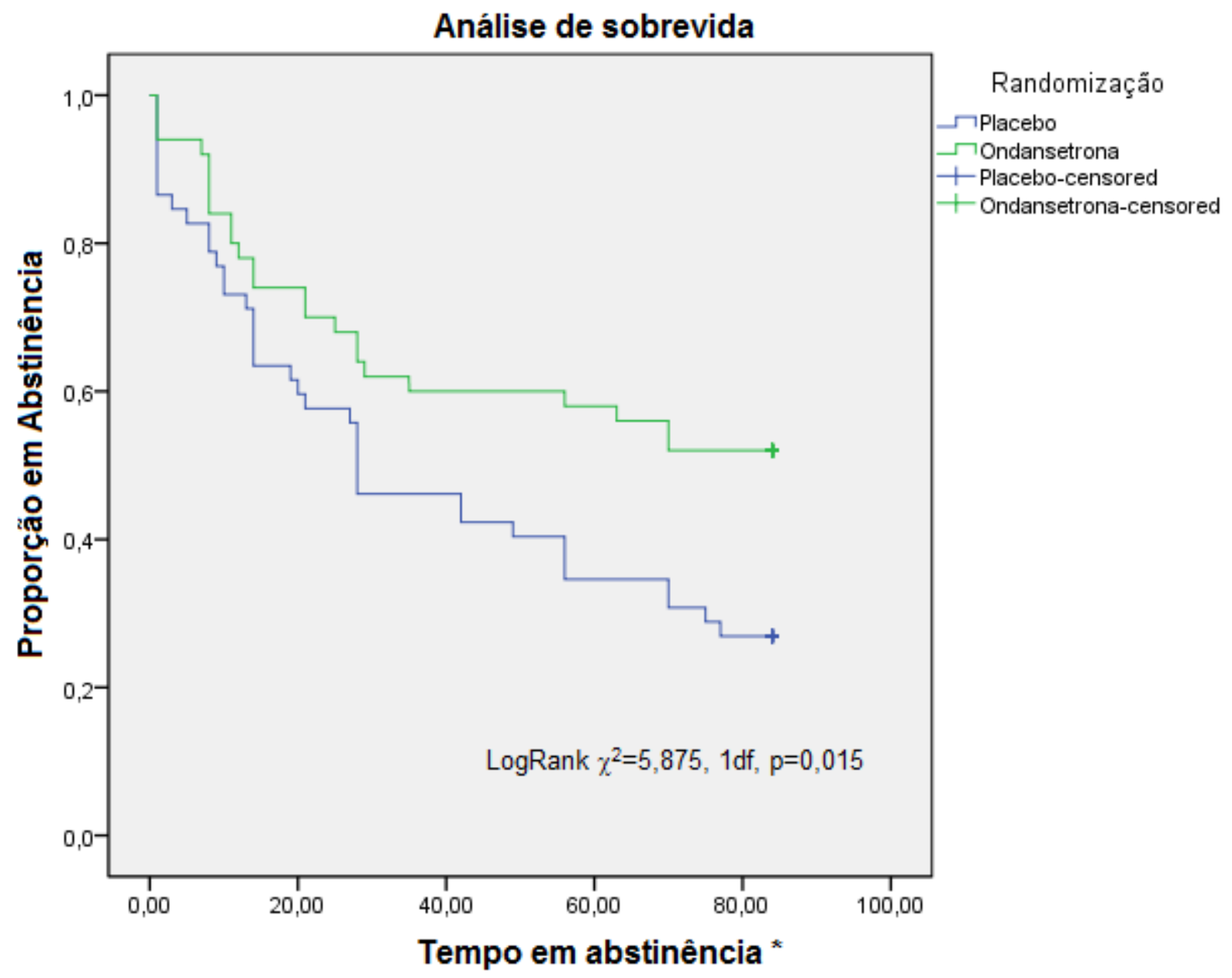

* Tempo para primeiro consumo de álcool expresso em dias. 
Figura 9. Curva de sobrevida de Kaplan-Meier, para primeiro consumo pesado de álcool, nos grupos placebo e ondansetrona.

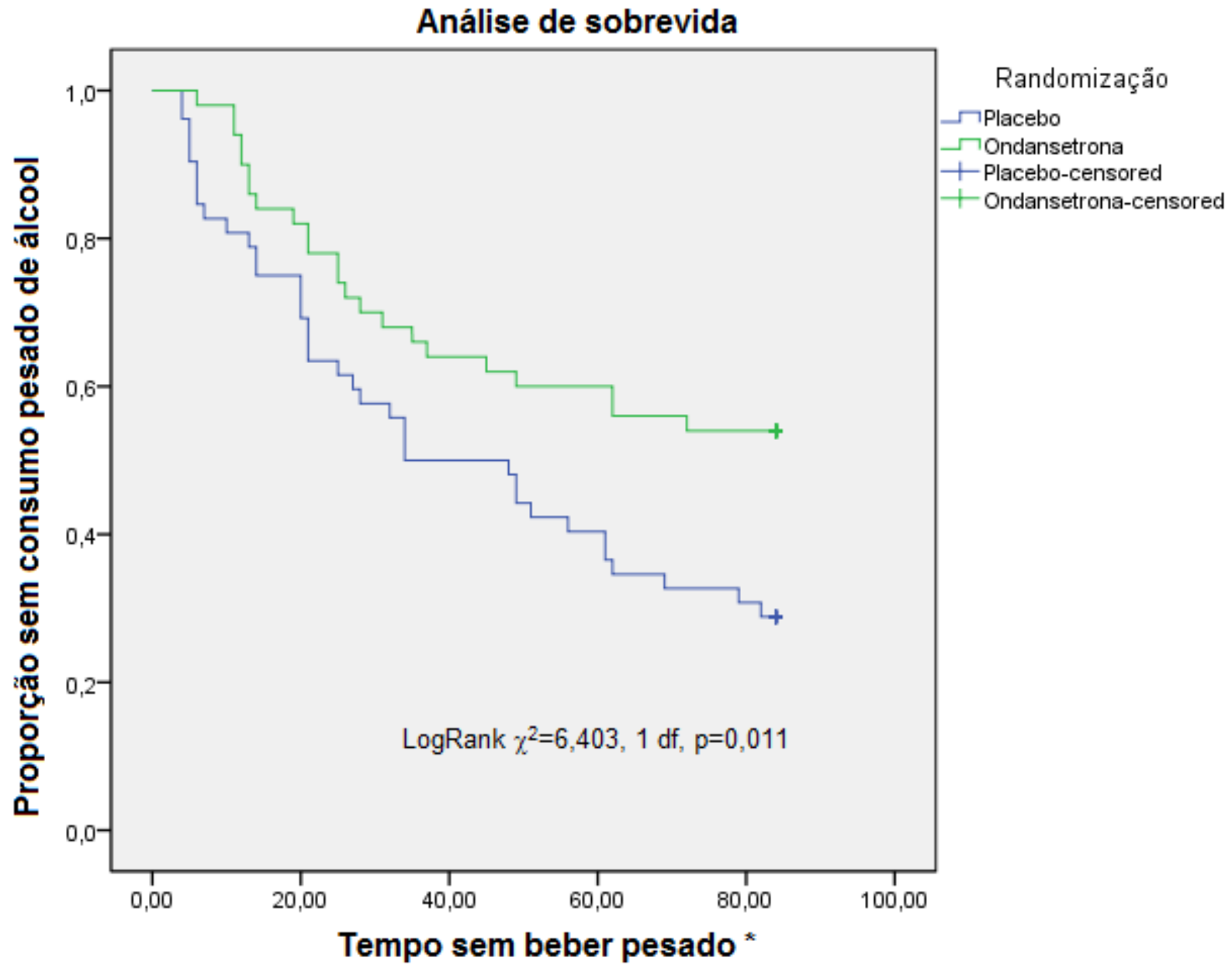

* Tempo para primeiro consumo de álcool expresso em dias. 


\subsubsection{Análise da retenção no tratamento}

Durante as 12 semanas de acompanhamento, 51 indivíduos terminaram o estudo (tabela 11). Dos 50\% que não completaram o estudo, os motivos que levaram ao desligamento foram: um caso $(2 \%)$ recusa em continuar fazendo o tratamento; treze integrantes (26\%) violaram o protocolo (deixaram de usar a medicação prescrita, usaram outra medicação que interferia no efeito da medicação avaliada); trinta e sete casos (72\%) deixaram de fazer o acompanhamento, não retornando à consulta agendada, também não responderam à convocação para retorno. A distribuição dos desligamentos entre os grupos foi 57,7\% (30 casos) no grupo placebo e 42\% (21 casos) no grupo ondansetrona. Mas essa diferença não foi significante do ponto de vista estatístico.

Tabela 11. Situação dos participantes quanto ao término do estudo, entre os grupos ondansetrona e placebo.

\begin{tabular}{lccc}
\hline \hline & $\begin{array}{c}\text { Ondansetrona } \\
(\mathrm{n}-50)\end{array}$ & $\begin{array}{c}\text { Placebo } \\
(\mathrm{n}=52)\end{array}$ & $\begin{array}{c}\text { Total } \\
(102)\end{array}$ \\
Recusa em continuar & 1 & - & 1 \\
Perda de seguimento & 13 & 24 & 37 \\
Violação de protocolo & 7 & 6 & 13 \\
Completaram estudo & 29 & 22 & 51 \\
\hline \hline$\left(\chi^{2}=5,271,3 \mathrm{df}, \mathrm{p}=0,153\right)$ & & &
\end{tabular}

$\mathrm{Na}$ busca de fatores que estivessem relacionados à descontinuação do tratamento, foram incluídas todas as variáveis clínicas e sociodemográficas. Realizamos a análise de regressão linear com GEE com as variáveis: idade, estado civil, raça, nível educacional, idade em que iniciaram os problemas com o consumo do álcool, história de tratamento prévio, bebida preferencial, presença de tabagismo, história familiar de alcoolismo, grupo de medicação (placebo e ondansetrona), tipologia do alcoolismo, escores médios psicométricos escala de depressão (Hamilton- 
21), escala de sintomas de abstinência (CIWA-AR), escala de gravidade do alcoolismo (SADD) e escala de "fissura" pelo álcool (OCDS). Foram identificadas como variáveis preditoras da descontinuação do tratamento a participação de indivíduos mais jovens e de não fumantes. A tipologia dos alcoolistas e o grupo de medicamento (ondansetrona ou placebo) não estavam associados à retenção no tratamento (tabela 12).

\subsubsection{Percentagem de dias abstinentes e percentagem de dias com consumo pesado de álcool}

Devido à considerável perda de dados, durante o estudo, resultando na taxa de desligamento de $50 \%$ e ao fato deste desligamento não ter acontecido ao acaso, a análise dos dados percentagem de dias abstinentes (PDA) e percentagem de dias com consumo pesado de álcool (PCP) foi realizada em três etapas: primeiro, com os dados dos participantes que completaram o estudo; segundo, foi realizada imputação múltipla dos dados faltantes, que teve como referência os fatores preditores de descontinuação do tratamento (idade e condição de tabagismo); por fim, a terceira etapa, com os dados imputados foi feita nova análise da PDA e PCP.

Considerando apenas os dados dos pacientes que completaram 0 estudo, a análise de GEE da proporção de dias abstinentes (figura 10), que teve em média durante o acompanhamento a proporção de $76,1 \%$, no grupo medicado com placebo, e $88,6 \%$, no ondansetrona, não apresentou diferença estatística significante $\left[\chi^{2}(12)=12,59, p=0,40\right]$. Para avaliar a possível influência da tipologia do alcoolista (bebedor precoce e tardio) na percentagem de dias abstinentes durante o estudo, foi verificada que a influência dessa tipologia não foi significante $\left[\chi^{2}(12)=13,44, p=0,34\right]$. Para verificar a interação entre a tipologia (precoce e tardio) e a medicação usada durante 0 estudo na PDA, foi conduzida nova análise, que também, não demonstrou significância $\left[\chi^{2}(12)=2,80, p=0,09\right]$. 
Tabela 12. Análise das características clínicas e sociodemográficas quanto à retenção no tratamento.

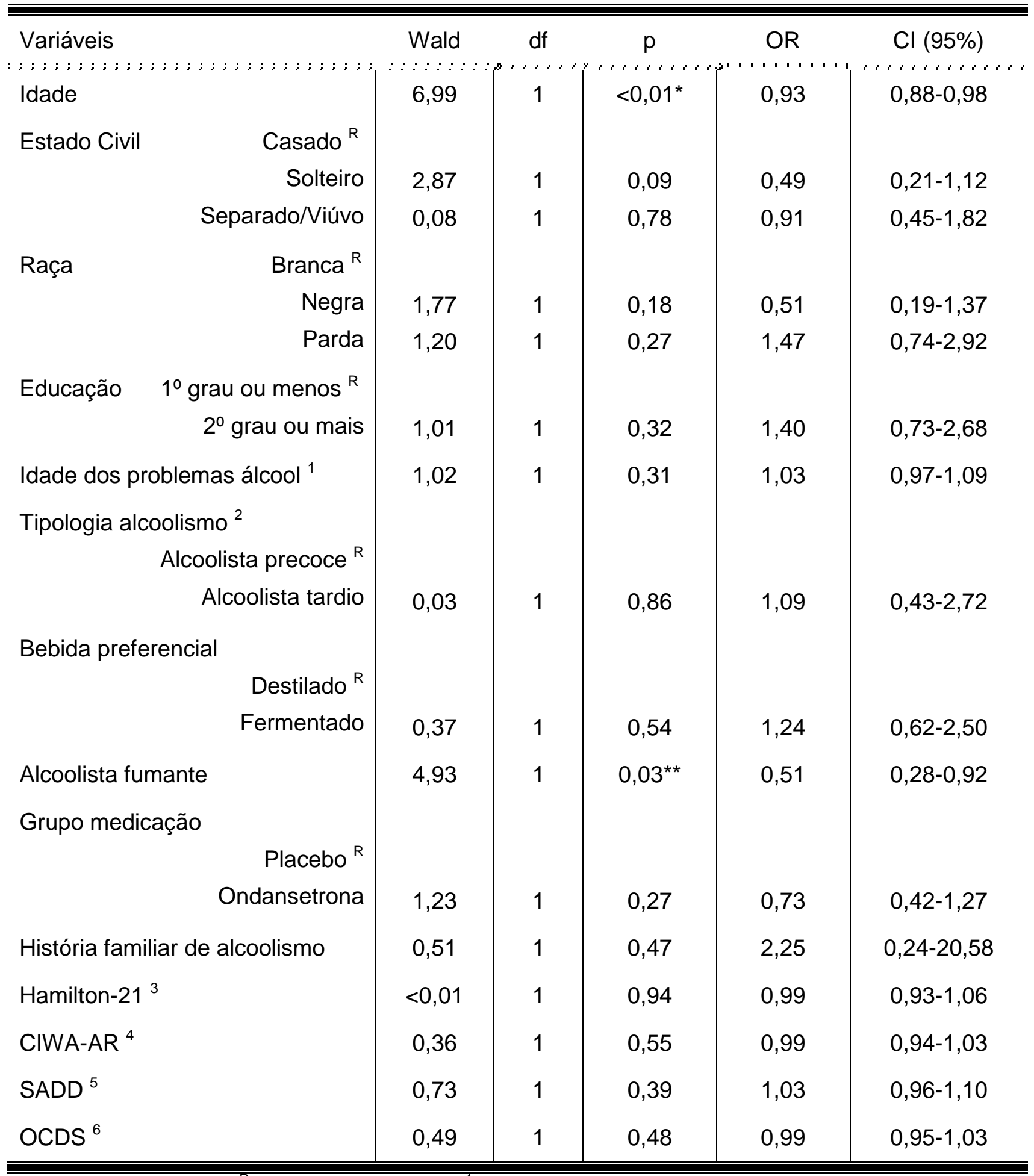

${ }^{*} \mathrm{p}<0,01 ;{ }^{\star \star} \mathrm{p}<0,05 ;{ }^{\mathrm{R}}$ variável referência; ${ }^{1}$ idade de início dos problemas com o consumo do álcool; ${ }^{2}$ Tipologia do alcoolismo definida pela idade de início dos problemas com álcool (antes dos 25 anos, alcoolista precoce, e após 25 anos, alcoolista tardio); ${ }^{3}$ Hamilton-21, escala de depressão de Hamilton; ${ }^{4}$ CIWA-AR, escala de sintomas de abstinência - Clinical Institute Withdrawal Assessment; ${ }^{5}$ SADD, escala de gravidade do alcoolismo - Short Alcohol Dependence Data; ${ }^{6}$ OCDS, escala de "fissura" pelo álcool - Obsessive Compulsive Drinking Scale. 
$\mathrm{Na}$ análise de GEE dos dados completos, quanto à influência da medicação na percentagem de dias bebidos pesados durante o estudo, não foi encontrada diferença estatística entre os grupos ondansetrona e placebo $\left[\chi^{2}(12)=15,52, p=0,16\right]$. Durante as doze semanas, houve a ocorrência de $9,5 \%$ de dias com consumo pesado de álcool no grupo medicado com placebo e de $5,9 \%$ no grupo medicado com ondansetrona (figura 11 ).

A avaliação da influência da tipologia do alcoolista (bebedor precoce ou tardio) sobre o PCP mostrou não haver diferença estatística significante $\left[\chi^{2}(12)=17,41, p=0,09\right]$. Na análise da interação entre essa tipologia e a medicação na proporção de dias com consumo pesado, também, não foi encontrada diferença estatística $\left[\chi^{2}(12)=2,95, p=0,10\right]$.

Posteriormente, após a fase da imputação dos dados perdidos usando as variáveis preditoras de abandono do tratamento (idade e tabagismo), foi realizada nova análise de GEE com os dados imputados. Não foi encontrada diferença estatística significante entre os grupos de medicação, quanto à proporção de dias abstinentes $\left[\chi^{2}(12)=7,92, p=0,79\right]$. A percentagem de dias abstinentes, média durante o estudo, foi de $66,6 \%$ nos participantes medicados com placebo e $77,9 \%$ nos medicados com ondansetrona (figura 12).

A análise da influência da tipologia do alcoolista na PDA, dos dados imputados, mostrou não haver interação significativa da tipologia $\left[\chi^{2}(12)=\right.$ $11,92, p=0,45]$. A avaliação da interação entre a tipologia e a medicação usada, na proporção de dias abstinentes não mostrou diferença significante do ponto de vista estatístico $\left[\chi^{2}(12)=0,06, p=0,81\right]$.

A análise de GEE, com os dados imputados, mostrou um efeito significativo da ondansetrona sobre o placebo em diminuir a percentagem de dias bebidos pesados $\left[\chi^{2}(12)=23,35, p=0,02\right]$, havendo uma proporção de $11,7 \%$ de dias bebidos pesados no grupo placebo e $7,8 \%$ no grupo ondansetrona, durante as 12 semanas de estudo (figura 13).

A análise da influência da tipologia do alcoolista na PCP mostrou que foi significante a interação da tipologia do alcoolismo durante $o$ tratamento $\left[\chi^{2}(12)=\right.$ 24,52, $p=0,02]$ com a proporção média de dias bebidos pesados, durante as 12 semanas, entre os bebedores de início precoce, de $12,9 \%$ e de início tardio de 
7,1\%. A interação entre a tipologia e a medicação usada durante as 12 semanas não foi significante $\left[\chi^{2}(12)=0,73, p=0,39\right]$. 
Figura 10. Percentagem de dias abstinentes, durante o estudo nos grupos ondansetrona e placebo.

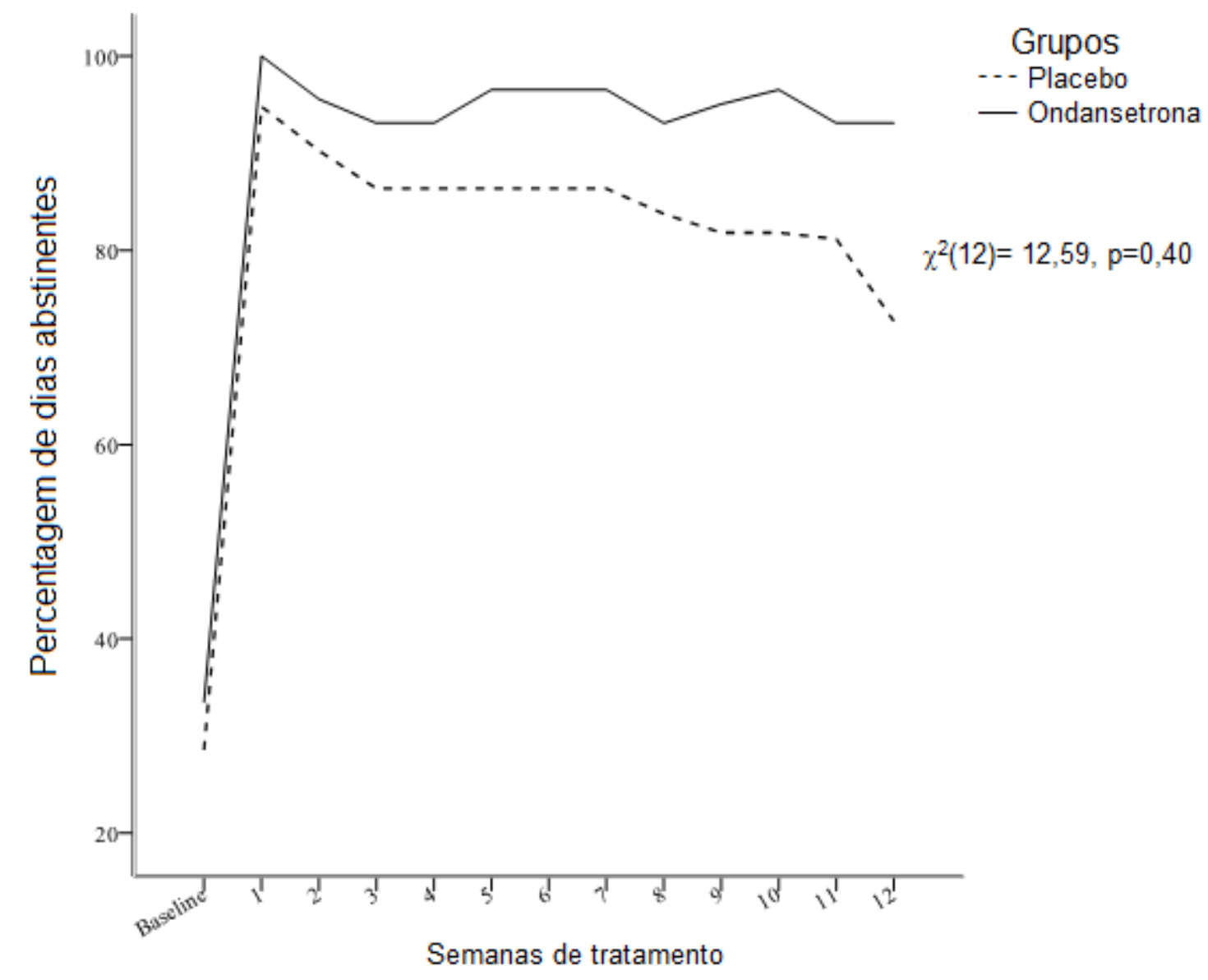


Figura 11. Percentagem de dias consumo pesados, durante o estudo nos grupos ondansetrona e placebo.

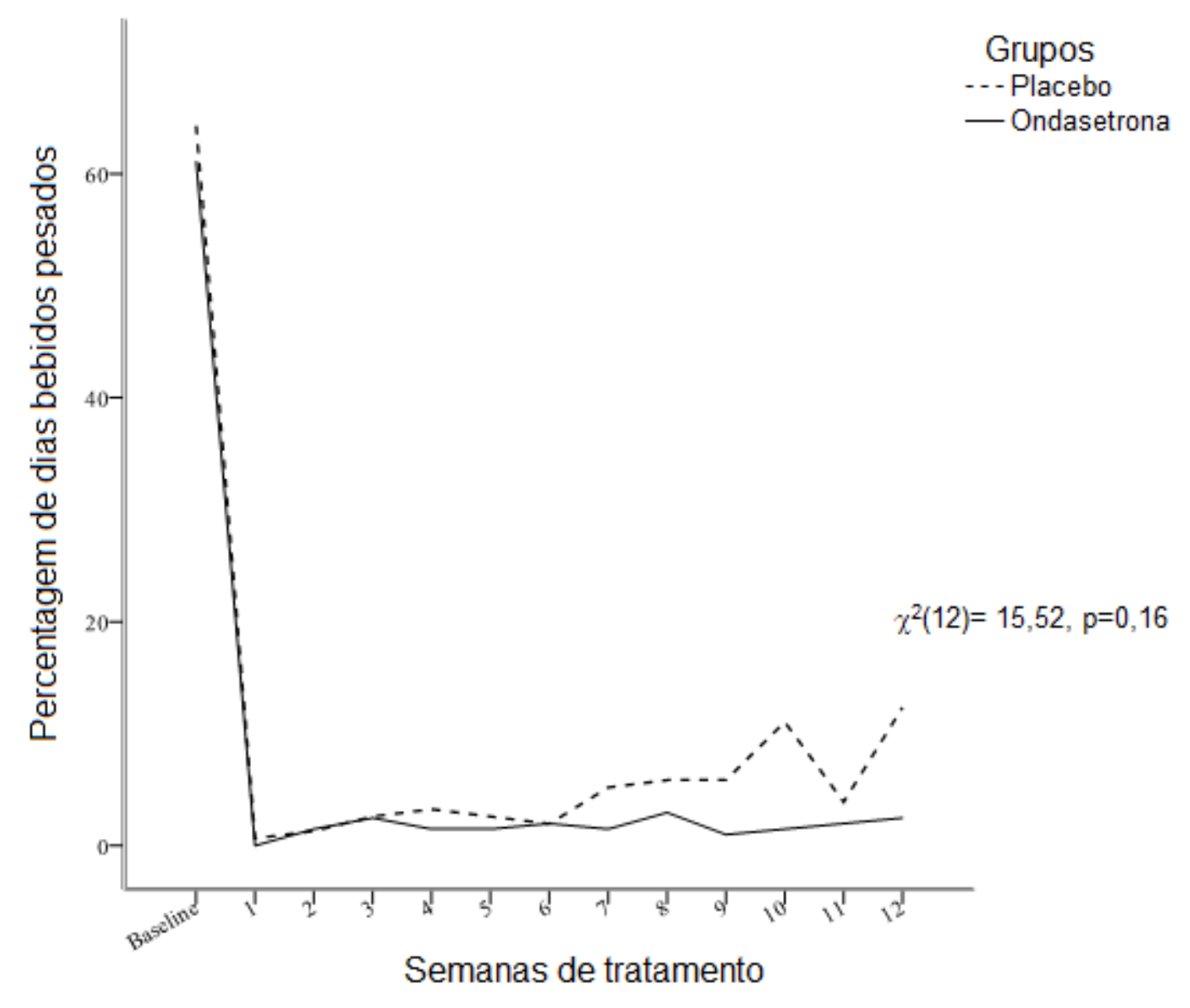


Figura 12. Proporcão de dias abstinentes no decorrer do estudo, análise com os dados imputados, nos grupos ondansetrona e placebo.

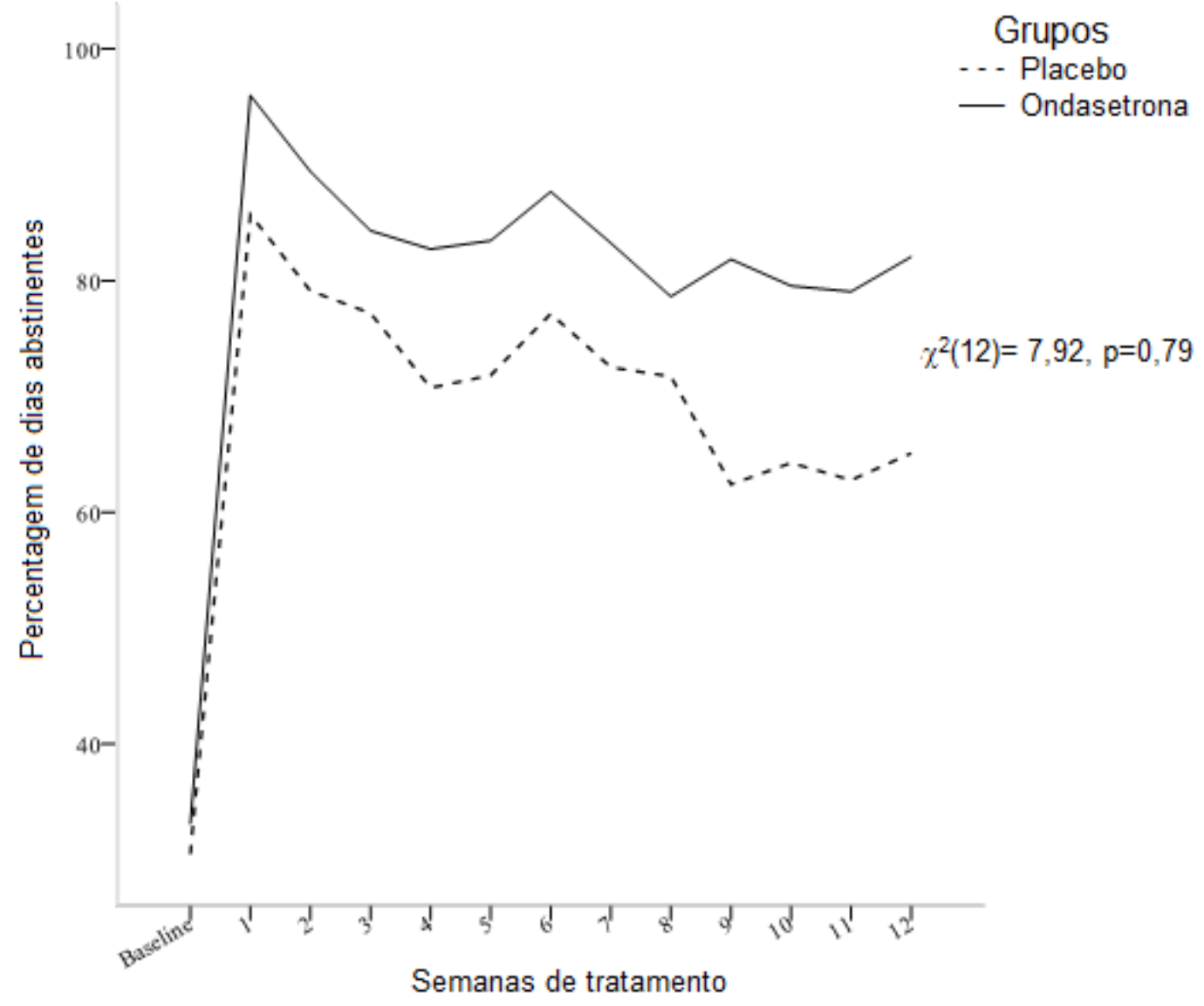


Figura 13. Proporcão de dias com consumo pesados de álcool no decorrer do estudo, análise com os dados imputados, nos grupos ondansetrona e placebo.

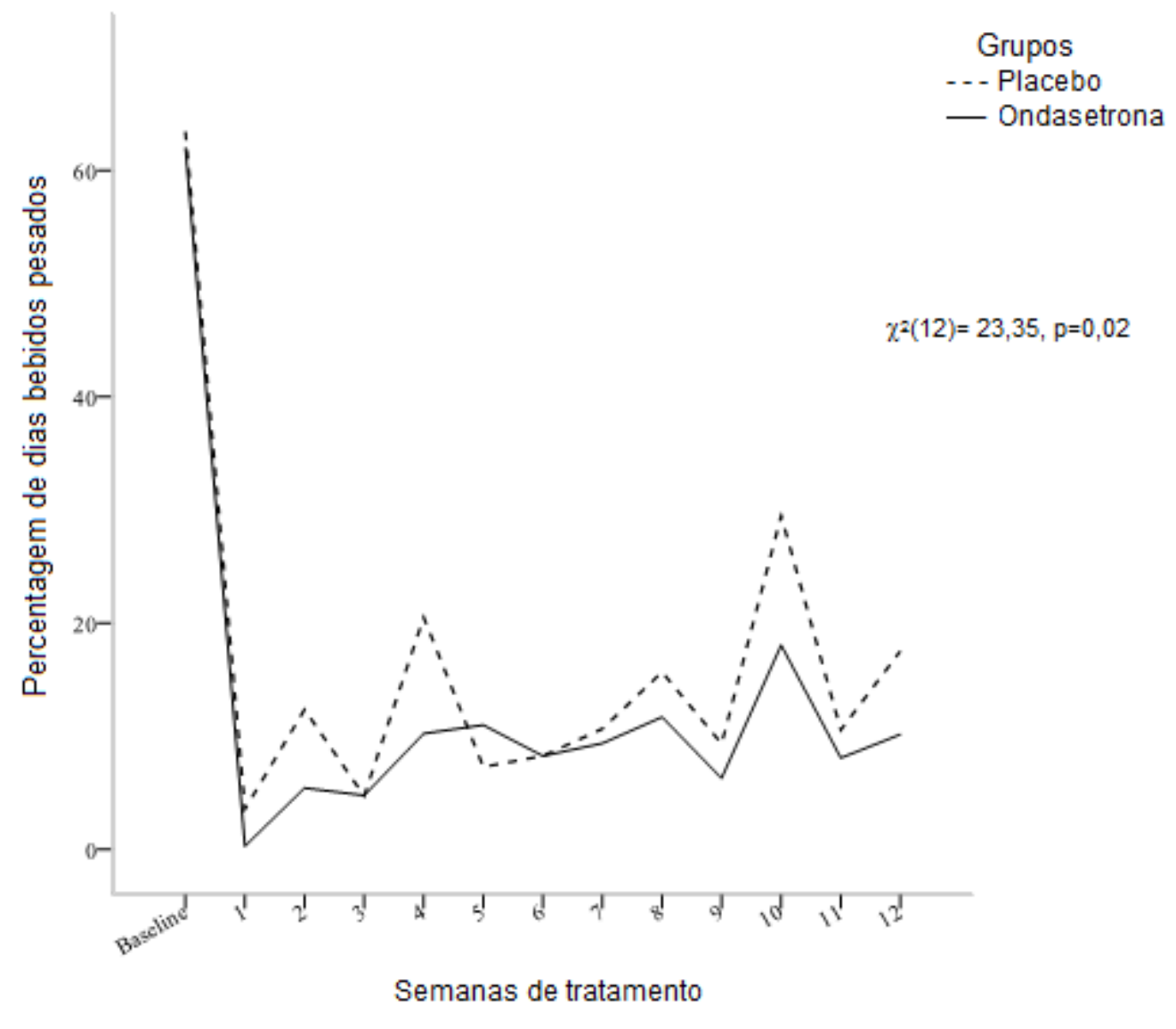




\subsubsection{Segurança e tolerância da ondansetrona}

De maneira geral, a medicação foi bem tolerada e sem ocorrência de sintomas clínicos graves que pudessem ser responsáveis pela descontinuação da medicação usada. A presença de sintomas clínicos associados a uso de medicação mostrou ser muito semelhante entre os grupos (ondansetrona e placebo), vide tabela 13. O único sintoma que foi mais frequente nos pacientes medicados com ondansetrona, foi a constipação, mas essa diferença não foi estatisticamente significante.

Tabela 13. Frequência de sintomas clínicos atribuídos à medicação nos grupos placebo e ondansetrona.

\begin{tabular}{l|c|c|c}
\hline \hline & Ondansetrona $(\mathrm{n}=50)$ & Placebo $(\mathrm{n}=52)$ & $\mathrm{p}(1 \mathrm{df})$ \\
Sem queixa & $48 \%(24)$ & $50 \%(26)$ & $\chi^{2}=0,04, \mathrm{p}=0,84$ \\
Cefaleia & $14 \%(7)$ & $17,3 \%$ & $\chi^{2}=0,21, \mathrm{p}=0,65$ \\
Sonolência & $2 \%$ & $3,9 \%$ & $\chi^{2}=0,30, \mathrm{p}>0,99$ \\
Dispepsia & $18 \%$ & $13,5 \%(7)$ & $\chi^{2}=0,39, \mathrm{p}=0,53$ \\
Constipação & $22 \%(11)$ & $11,5 \%(6)$ & $\chi^{2}=2,01, \mathrm{p}=0,16$ \\
Diarreia & $2 \%$ & $5,8 \%$ & $\chi^{2}=0,96, \mathrm{p}=0,62$ \\
Prurido & $6 \%$ & $5,8 \%$ & $\chi^{2}<0,01, \mathrm{p}>0,99$ \\
Sintoma GU & $8 \%(4)$ & $9,6 \%(5)$ & $\chi^{2}=0,08, \mathrm{p}=0,77$ \\
\hline \hline
\end{tabular}

* Sintomas GU, sintomas geniturinários, foram agrupados devido à baixa frequência observada (impotência, ejaculação precoce, disúria, polaciúria, ejaculação retardada, anorgasmia).

\subsubsection{Integridade do estudo duplo-cego}

O pesquisador e os pacientes foram avaliados quanto à integridade do cegamento durante o acompanhamento. O pesquisador opinou sobre a qual grupo o paciente pertencia (placebo ou ondansetrona) tendo acertado 
em 58 casos (56,9\%). Os participantes foram questionados, várias vezes, durante as 12 semanas, sendo assertivos em 55 casos $(53,9 \%)$. Essa diferença não foi estatisticamente significante (tabela 14).

Tabela 14. Integridade do estudo, número e percentagens de impressões certas e erradas do pesquisador e participantes da pesquisa quanto ao uso da medicação testada.

\begin{tabular}{cccc}
\hline \hline $\mathrm{n}=102$ & Impressões certas & Impressões erradas & $\mathrm{p}(1 \mathrm{df})$ \\
\hline \hline Pesquisador $\mathrm{n}(\%)$ & $58(56,9)$ & $44(43,1)$ & $\chi^{2}=2,21, \mathrm{p}=0,14$ \\
Participantes $\mathrm{n}(\%)$ & $55(53,9)$ & $47(46,1)$ & $\chi^{2}=0,74, \mathrm{p}=0,39$ \\
\hline \hline
\end{tabular}

\subsubsection{Poder e tamanho da amostra}

Para analisar o poder da amostra foi utilizado o programa estatístico "G*Power 3". Realizou-se uma MANOVA para medidas repetidas, com teste de interação entre elas. O valor de significância usado foi de 0,05, e o teste usado foi bicaudal. Para o cálculo do poder da amostra consideraram-se apenas os dados dos participantes que terminaram o ensaio clínico.

No que diz respeito à "percentagem de dias abstinentes" durante o estudo, a amostra de 51 pacientes aderentes alcançou um poder de $33 \%$ em detectar diferença entre os dois grupos (placebo ou ondansetrona), versus a hipótese de igualdade entre as condições.

Teoricamente, uma amostra de 289 sujeitos aderentes seria necessária para atingir um poder de $80 \%$, com um tamanho de efeito de $25 \%$ [Pillai $V=0,05$, Wilks ` $\lambda=18,06, F(12,276)=1,79]$. Considerando-se que metade dos sujeitos pode não terminar o estudo com desenho e amostra similares, um total de 578 sujeitos seriam necessários para produzir resultados significativos na análise de "percentagem de dias abstinentes", pelo menos do ponto de vista teórico. 


\subsection{Formulação da tipologia para alcoolistas}

\subsubsection{Características dos participantes dos três estudos}

Entre os anos de 2001 a 2010, três ensaios clínicos foram realizados, com um total de 451 pessoas com síndrome de dependência do álcool, no setor de assistência do PROGREA. Após serem convidados para participar dos estudos (acamprosato versus placebo; topiramato, naltrexona versus placebo; ondansetrona versus placebo), apenas 364 aceitaram (87 pacientes não quiseram participar e 32 candidatos foram desligados por não preencherem todos os critérios). No total, 332 sujeitos foram eleitos para randomização, sendo sorteados para receberem o placebo ou medicação ativa. $O$ grupo placebo foi o mais numeroso, com 141 participantes, por ter sido um grupo presente nos três estudos. Nos grupos medicados com fármacos ativos, 50 participantes receberam ondansetrona, 52 topiramato, 49 naltrexona e 40 acamprosato (figura 14 ).

Dos 332 eleitos no início dos estudos, 138 foram desligados dos ensaios clínicos (por três razões: violação de protocolo, recusa em continuar e deixaram de acompanhar) e 194 pacientes completaram o período de 12 semanas de tratamento. Dos aderentes, 73 estavam no grupo placebo; 29 no grupo ondansetrona; 33 no grupo topiramato; 29 no grupo naltrexona; por fim, 30 no grupo acamprosato.

\subsubsection{Desenvolvimento da tipologia}

Para determinação dos clusters, usamos como base as características clínicas: alcoolismo familiar; idade de início dos problemas com uso do álcool, escores de gravidade do alcoolismo (SADD) e intensidade de sintomas depressivos. As variáveis escolhidas para formulação da tipologia já foram usadas em estudos prévios para desenvolvimento da tipologia para alcoolistas (Hauser, 1997). 
Figura 14. Fluxograma dos participantes dos ensaios envolvidos no estudo, de 2001 a 2010.

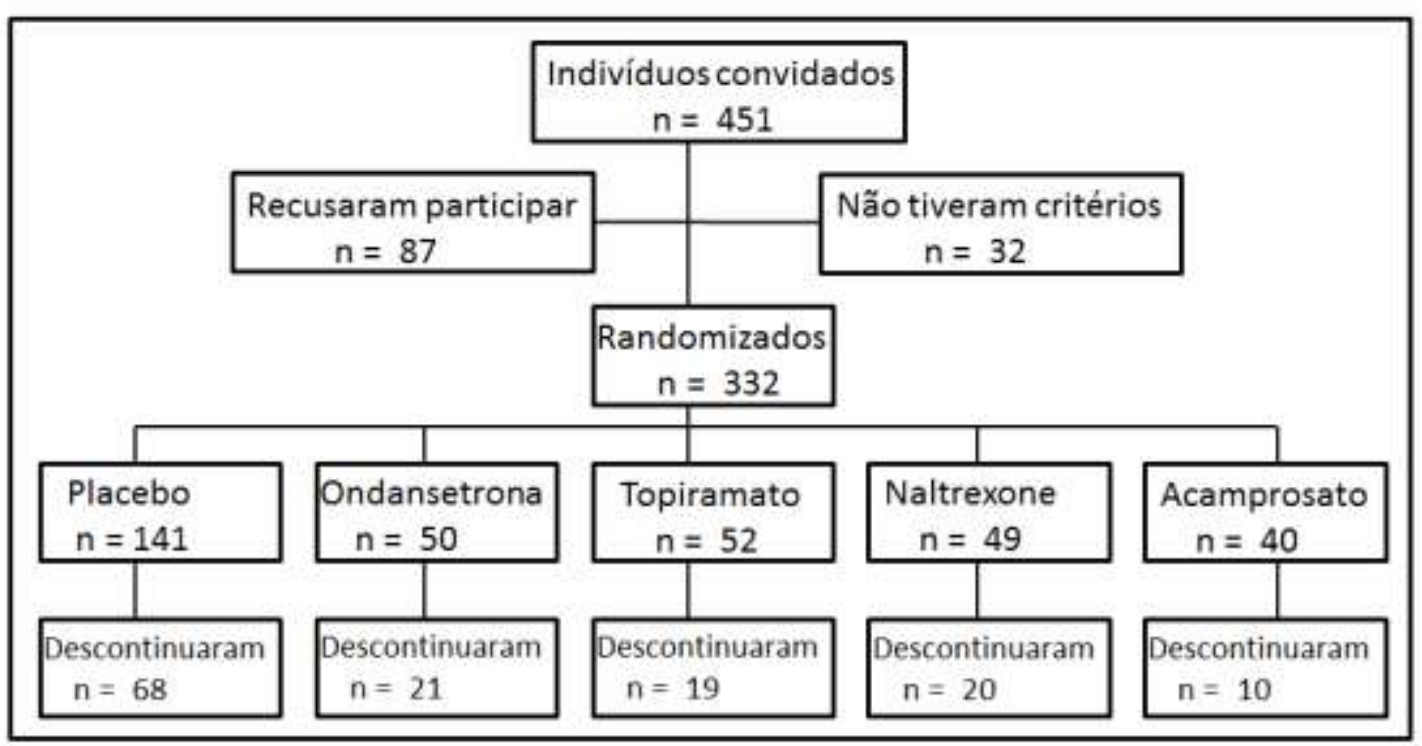

Para determinar o número de clusters a serem elaborados, foi utilizado o índice da silhueta com distância euclidiana, através da análise tipo K-means (k-médios). Os gráficos dos clusters feitos por este método mostraram o quanto distantes esses aglomerados ficavam uns dos outros. Para a tipologia com dois clusters, o índice de silhueta foi maior que 0,5, já para a tipologia com o número de três ou quatro clusters o índice da silhueta foi menor que 0,5 . Como o valor do índice da silhueta foi maior com dois grupos, este foi o número de clusters usado para formular a tipologia.

Tendo como base essa tipologia, foi identificado que 169 participantes $(50,9 \%)$ pertenciam ao cluster chamado tipo 1 e 163 dependentes $(49,1 \%)$ ao chamado tipo 2. Esse grupo tipo 1 foi caracterizado por pessoas com início dos problemas com o consumo do álcool mais tardio $(36,2$ anos versus 28,8 anos), história familiar de alcoolismo menos frequente ( 0,43 versus $0,47)$, menor gravidade do alcoolismo, medido pelo $\operatorname{SADD}(25,3$ versus 33,2$)$ e níveis mais elevados de sintomas depressivos $(10$ versus 7,8$)$ do que os dependentes pertencentes ao cluster tipo 2 (tabela 15). 
Tabela 15. Distribuição e características dos pacientes dentro das duas tipologias propostas.

\begin{tabular}{|c|c|c|c|c|}
\hline Tipologia & $\begin{array}{l}\text { Idade de início } \\
\text { dependência }\end{array}$ & $\begin{array}{l}\text { Carga familiar de } \\
\text { alcoolismo }\end{array}$ & SADD & Hamilton \\
\hline $\begin{array}{l}\text { Tipo } 1(50,9 \%) \\
n=169\end{array}$ & $36,2(9,84)$ & $0,43(0,11)$ & $25,27(7,72)$ & $10,01(6,43)$ \\
\hline $\begin{array}{l}\text { Tipo } 2(49,1 \%) \\
n=163\end{array}$ & $28,75(6,71)$ & $0,47(0,09)$ & $33,17(7,16)$ & $7,82(5,63)$ \\
\hline $\mathrm{F}$ & 64,52 & 5,28 & 93,23 & 10,80 \\
\hline$p$ & $<0,01$ & $<0,05$ & $<0,01$ & $<0,01$ \\
\hline
\end{tabular}

(clusters formados pelo método K-means, índice da silhueta Euclidiana > 0,5). 


\subsubsection{Característica clínica dos clusters tipo 1 e 2}

Os participantes dos dois clusters não tiveram diferença estatística significante quanto a: raça, nível educacional, histórico de tratamento prévio para o alcoolismo, história de participação nos Alcoólicos Anônimos, tipo de bebida preferencial, medicação usada durante o tratamento, consumo de tabaco, volume corpuscular médio (VCM), aspartato aminotransferase (AST) e gama glutamil transpeptidase (GGT) (tabela 16).

Os pertencentes ao cluster tipo 2 tipicamente eram mais jovens, com maior chance de serem solteiros, consumiam mais álcool, tinham carreira de alcoolismo menor, história de alcoolismo familiar mais frequente, escores de "fissura" pelo álcool elevados e níveis séricos de alanina aminotransferase (ALT) mais alterados.

Os participantes do cluster tipo 1 se caracterizavam por terem idades mais elevadas, menor chance de ser solteiro, menor consumo de álcool, carreira de consumo de álcool mais longa, história familiar de alcoolismo menos frequente, menor "fissura" pelo álcool e níveis séricos de ALT menos alterados. 
Tabela 16. Características clínicas dos clusters tipo 1 e 2 proposta para os alcoolistas

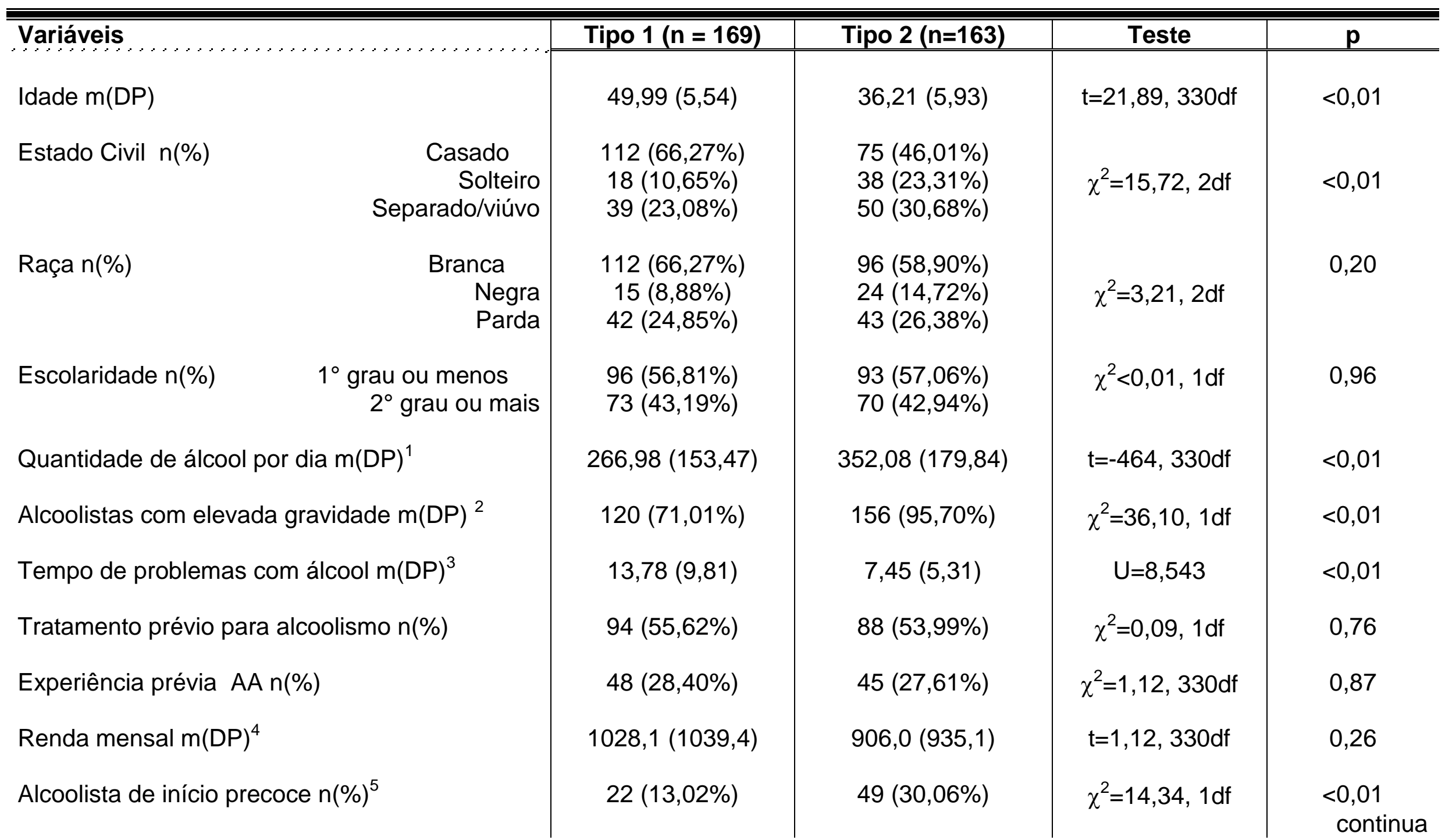




\begin{tabular}{|c|c|c|c|c|}
\hline Bebida preferencial $n(\%)$ & $\begin{array}{c}117(69,23 \%) \\
49(28,99 \%) \\
3(1,78 \%)\end{array}$ & $\begin{array}{c}122(74,85 \%) \\
39(23,93 \%) \\
2(1,22 \%)\end{array}$ & $\chi^{2}=1,39,2 \mathrm{df}$ & 0,55 \\
\hline $\begin{array}{r}\text { Placebo } \\
\text { Ondansetrona } \\
\text { Topiramato } \\
\text { Naltrexona } \\
\text { Acamprosato }\end{array}$ & $\begin{array}{l}68(40,24 \%) \\
28(16,57 \%) \\
28(15,38 \%) \\
26(15,38 \%) \\
19(11,27 \%)\end{array}$ & $\begin{array}{l}73(44,78 \%) \\
22(13,50 \%) \\
24(14,72 \%) \\
23(14,11 \%) \\
21(12,89 \%)\end{array}$ & $\chi^{2}=1,38,4 \mathrm{df}$ & 0,85 \\
\hline $\mathrm{ALT} \quad \mathrm{m}(\mathrm{DP})$ & $33,12(22,19)$ & $42,83(34,16)$ & $U=10.779,50$ & $<0,01$ \\
\hline AST $m(D P)$ & $37,22(26,52)$ & $48,57(49,25)$ & $U=11.983,50$ & 0,21 \\
\hline VCM m & $94,60(6,87)$ & $94,98(7,09)$ & $t=-0,48,330 d f$ & 0,63 \\
\hline
\end{tabular}

quantidade de álcool em gramas, consumido nos 3 meses anteriores a cada estudo; ${ }^{2}$ Alcoolistas com pontuação maior que 20 na escala Short Alcohol Dependence Date (SADD); ${ }^{3}$ Tempo de problemas com álcool, ou intervalo em anos entre o início dos problemas com álcool e o estudo; ${ }^{4}$ renda mensal em reais; ${ }^{5}$ Alcoolistas de início precoce, aqueles que iniciaram problemas com álcool antes dos 25 anos de idade; ${ }^{6}$ Alcoolistas com sintomas depressivos que tiveram pontuação maior que 7 na escala de depressão de Hamilton; GGT, nível sérico de gama glutamil transpeptidase; ALT, alanina aminotransferase; AST, aspartato aminotransferase; VCM, volume corpuscular sérico; CIWA-AR, Clinical Institute Withdrawal Assessment; AUDIT, The Alcohol Use Disorders Identification; OCDS, Obsessive-Compulsive Drinking Scale. 


\subsubsection{Tipologia e motivos de descontinuação do tratamento}

Dos 138 dependentes de álcool que abandonaram 0 acompanhamento, 57 eram do cluster tipo1 e 81 deles eram do tipo 2. As análises das razões que levaram os participantes a interromper os estudos não foram diferentes entre os dois grupos. $O$ abandono do acompanhamento ocorreu em 41 participantes $(71,9 \%)$ do primeiro tipo e 58 sujeitos $(71,6 \%)$ do segundo tipo. A recusa em continuar foi motivo para desligamento em 9 participantes $(15,8 \%)$ do tipo 1 e 15 integrantes $(18,5 \%)$ do grupo 2. A violação do protocolo ocorreu em 7 pacientes (12,3\%) do primeiro cluster e em 7 integrantes $(9,9 \%)$ do segundo tipo.

A análise das razões para descontinuar o tratamento dentro de cada cluster foi realizada e não mostrou diferença estatística. (tabela 17). A análise das razões para descontinuar o tratamento, entre os clusters, não mostrou influência estatisticamente significante da medicação usada. 
Tabela 17. Motivos de descontinuação dos estudos nos clusters no geral e por grupo de medicação.

\begin{tabular}{|c|c|c|c|c|c|c|c|}
\hline "Cluster" & $\begin{array}{l}\text { Placebo } \\
(n=68)\end{array}$ & $\begin{array}{l}\text { Ondansetrona } \\
(n=21) \ldots\end{array}$ & Acamprosato & $\begin{array}{l}\text { Naltrexona } \\
(\mathrm{n}=20)\end{array}$ & Topiramato & $\begin{array}{l}\text { Teste } \\
\ldots \ldots .\end{array}$ & $p$ \\
\hline Abandono $n(\%)$ & $22(32,4 \%)$ & $5(23,8 \%)$ & $1(10 \%)$ & $9(45 \%)$ & $4(21,1 \%)$ & \multirow{4}{*}{$\chi^{2}=8,91,8 \mathrm{df}$} & \multirow{4}{*}{0,30} \\
\hline Violação protocolo n(\%) & $5(7,4 \%)$ & $2(9,5 \%)$ & $0(0 \%)$ & $0(0 \%)$ & $2(10,5 \%)$ & & \\
\hline Recusa em continuar $n(\%)$ & $2(2,9 \%)$ & $1(4,8 \%)$ & $0(0 \%)$ & $1(5 \%)$ & $3(15,8 \%)$ & & \\
\hline Total n(\%) & $29(42,6 \%)$ & $8(38,1 \%)$ & $1(10 \%)$ & $10(50 \%)$ & $9(47,4 \%)$ & & \\
\hline & & & \multicolumn{2}{|c|}{${ }^{\mathrm{B}} \chi^{2}=0,76,2 \mathrm{df}$} & & & \\
\hline $\begin{array}{l}\text { Tipo } 2 \\
\text { Abandono } n(\%)\end{array}$ & $30(44,1 \%)$ & $8(38,1 \%)$ & $6(60 \%)$ & $8(40 \%)$ & $6(31,6 \%)$ & \multirow{4}{*}{$\chi^{2}=7,42,8 \mathrm{df}$} & \multirow{4}{*}{0,42} \\
\hline Violação protocolo n(\%) & $6(8,8 \%)$ & $5(23,8 \%)$ & $1(10 \%)$ & $1(5 \%)$ & $3(15,8 \%)$ & & \\
\hline Recusa em continuar $\mathrm{n}(\%)$ & $3(4,4 \%)$ & $0(0 \%)$ & $2(20 \%)$ & $1(5 \%)$ & $1(5,3 \%)$ & & \\
\hline Total n(\%) & $39(57,4 \%)$ & $13(61,9 \%)$ & $9(90 \%)$ & $10(50 \%)$ & $10(52,6 \%)$ & & \\
\hline Teste $^{\mathrm{C}}$ & $\chi^{2}=0,20,2 \mathrm{df}$ & $\chi^{2}=1,78,2 \mathrm{df}$ & $\chi^{2}=1,52,2 \mathrm{df}$ & $\chi^{2}=1,24,2 \mathrm{df}$ & $\chi^{2}=1,54,2 \mathrm{df}$ & & \\
\hline $\mathrm{p}$ & $>0,99$ & 0,60 & $>0,99$ & $>0,99$ & 0,59 & & \\
\hline
\end{tabular}




\subsubsection{Tipologia e participação nos Alcoólicos Anônimos}

A participação no AA foi praticamente a mesma nos dois tipos, 38 pacientes do tipo 1 e 35 integrantes do tipo 2, ou seja, 22,5\% e 21,5\%, respectivamente. Porém, a análise da influência dos grupos de medicações, nos dois tipos de alcoolistas, mostrou a existência de variação dentro de cada cluster, no número de participantes do $\mathrm{AA}$, conforme o grupo de medicação usada (tabela 18).

Após a realização da correção de Yates para os integrantes do tipo 1, os sujeitos medicados com acamprosato foram mais participativos no grupo de mútua ajuda, que os medicados com placebo, ondansetrona, naltrexona e topiramato $\left(\chi^{2}=13,20,1 \mathrm{df}, \mathrm{p}<0,01 ; \chi^{2}=6,67,1 \mathrm{df}, \mathrm{p}<0,01 ; \chi^{2}=16,02,1 \mathrm{df}\right.$, $p<0,01 ; \chi^{2}=5,35,1 d f, p=0,02$, respectivamente).

No cluster tipo 2, também, após a correção de Yates, os pacientes medicados com acamprosato tiveram mais participação no $A A$ que os sujeitos que receberam ondansetrona, naltrexona e topiramato $\left(\chi^{2}=8,33,1 \mathrm{df}\right.$, $p<0,01 ; \chi^{2}=8,78,1 d f, p<0,01 ; \chi^{2}=5,12,1 d f, p=0,02$, respectivamente). Ainda, nesse tipo, os participantes que receberam placebo compareceram mais frequentemente nos alcoólicos anônimos que os medicados com ondansetrona e naltrexona $\left(\chi^{2}=3,89,1 \mathrm{df}, \mathrm{p}=0,049 ; \chi^{2}=4,17,1 \mathrm{df}, \mathrm{p}=0,04\right.$, respectivamente). 
Tabela 18. Participação no AA nos clusters, no geral e por grupo de medicação.

\begin{tabular}{|c|c|c|c|c|c|c|c|}
\hline cluster & $\begin{array}{l}\text { Placebo } \\
(n=141)\end{array}$ & $\begin{array}{l}\text { Ondansetrona } \\
(n=50)\end{array}$ & $\begin{array}{l}\text { Acamprosato } \\
(n=40)\end{array}$ & $\begin{array}{l}\text { Naltrexona } \\
\quad(n=49) \\
\therefore: \therefore:\end{array}$ & $\begin{array}{l}\text { Topiramato } \\
(n=52) \\
: \therefore:: ;:\end{array}$ & Teste & $p$ \\
\hline $\begin{array}{l}\text { Tipo } 1 \text { n(\%) } \\
\text { Participação AA }\end{array}$ & $12(8,5 \%)$ & $6(12 \%)$ & $12(30 \%)$ & $1(2,0 \%)$ & $7(13,5 \%)$ & $\chi^{2}=21,55,4 d f$ & $<0,01$ \\
\hline
\end{tabular}

${ }^{\mathrm{B}} \chi^{2}=0,05,1 \mathrm{df}, 0,82$

\begin{tabular}{|c|c|c|c|c|c|c|c|}
\hline $\begin{array}{l}\text { Tipo } 2 \text { n(\%) } \\
\text { Participação AA }\end{array}$ & $20(14,2 \%)$ & $1(2 \%)$ & $10(25 \%)$ & $1(2,0 \%)$ & $3(5,8 \%)$ & $\chi^{2}=18,10,4 d f$ & $<0,01$ \\
\hline$p$ & 0,17 & 0,12 & 0,32 & $>0,99$ & 0,31 & & \\
\hline
\end{tabular}

${ }^{\mathrm{A}}$ Avaliação dentro de cada cluster da participação no AA entre os grupos de medicação; ${ }^{\mathrm{B}}$ Comparação entre os clusters da participação no AA; ${ }^{C}$ Testes avaliando a participação no AA entre os clusters e cada medicação. 


\subsubsection{Tipologia do alcoolista, medicamento e participação no AA}

Para avaliar a influência da tipologia do alcoolista, participação no AA e grupo de medicação na retenção no tratamento, foi realizada uma regressão linear direta, usando um modelo completo, com todas as variáveis e com uma constante. Essa análise mostrou significância estatística, $\chi^{2}=32,59,6 \mathrm{df}, p<0,01$ (tabela 19). A variância entre os membros dos grupos ocorreu de forma marginal (com Nagelkerke $R^{2}=0,13$ ). A taxa de sucesso do modelo para prever foi de $63,3 \%$.

Com base nos critérios de Wald, os alcoolistas pertencentes ao tipo 2 tiveram maior risco de abandonar o tratamento, independente do medicamento usado e da participação no $\mathrm{AA}$ (Wald = 8,72, $1 \mathrm{df}, \mathrm{p}<0,01$, $\mathrm{OR}=0,50, \quad \mathrm{IC}-95=0,31-0,79)$. A participação nos alcoólicos anônimos mostrou que aumenta a chance de o alcoolista aderir ao tratamento, independente da medicação usada e da tipologia do alcoolista (Wald = $14,08,1 \mathrm{df}, \mathrm{p}<0,01, \mathrm{OR}=3,51$, IC-95=1,82-6,76). A verificação do ajuste do modelo foi feito pelo teste de Lemeshow e Hosmer $\left(\chi^{2}=1,49,7 \mathrm{df}, p=0,98\right)$.

$\mathrm{Na}$ verificação da interação entre o tipo do alcoolista e o grupo de medicação usada, não houve diferença estatística significante para o cluster tipo 2 (Wald =3,08, $4 \mathrm{df}, \mathrm{p}=0,54$ ). Por outro lado, a interação entre o tipo $1 \mathrm{e}$ a medicação testada teve significância estatística (Wald $=12,29,4 \mathrm{df}$, $\mathrm{p}=0,01$ ). Essa interação foi maior no grupo acamprosato (Wald $=7,28,1 \mathrm{df}$, $p<0,01, \quad O R=16,36, \quad I C-95=2,15-124,61)$. Uma possível explicação para essa interação é o fato de que apenas 1 dos 10 participantes, que receberam acamprosato e não terminaram o tratamento, pertencia ao cluster tipo 1. 
Tabela 19. Retenção no tratamento por influência do tipo de cluster do alcoolista, da medicação e da participação no AA.

\begin{tabular}{|c|c|c|c|c|c|c|}
\hline Variáveis & $\overline{\text { SE }}$ & Wald & df & $\bar{p}$ & OR & IC-95\% \\
\hline \multicolumn{7}{|c|}{ 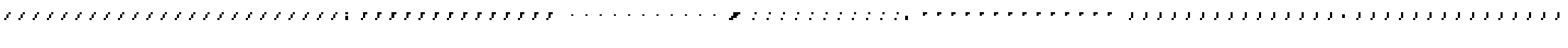 } \\
\hline Constante & 0,22 & 0,54 & 1 & 0,46 & 1,18 & - \\
\hline cluster tipo 2 & 0,23 & 8,72 & 1 & $<0,01$ & 0,50 & $0,31-0,79$ \\
\hline Grupo medicação & - & 5,38 & 4 & 0,25 & - & - \\
\hline Ondansetrona & 0,35 & 0,93 & 1 & 0,33 & 1,40 & $0,71-2,76$ \\
\hline Acamprosato & 0,43 & 3,08 & 1 & 0,08 & 2,12 & $0,92-4,90$ \\
\hline Naltrexona & 0,35 & 2,08 & 1 & 0,15 & 1,65 & $0,83-3,28$ \\
\hline Topiramato & 0,35 & 2,37 & 1 & 0,12 & 1,71 & $0,86-3,37$ \\
\hline Participação no AA & 0,33 & 14,08 & 1 & $<0,01$ & 3,51 & $1,82-6,76$ \\
\hline
\end{tabular}




\subsubsection{Variáveis relacionadas à tipologia, medicamento e participação no grupo do $A A$}

Para avaliar se as variáveis usadas para construção da tipologia do alcoolista, influenciaram, de forma independente, a retenção no tratamento, foi realizada a transformação delas em variáveis categóricas (tabela 20). Assim, as variáveis passaram a ser dicotômicas. Esta transformação é frequentemente usada para fins clínicos e de pesquisa. A escala de gravidade de alcoolismo (SADD) e de depressão de Hamilton não têm pontos de cortes validados até o momento. Os participantes que tinham pontuações maiores que 20 no "Short Alcohol Dependece Date" foram definidos como dependentes de álcool de grave intensidade. Já, os integrantes que tiveram pontuação menor que 7 na escala de depressão de Hamilton foram rotulados como portadores de sintoma depressivo, leve a moderado. Os pacientes com problemas com o consumo do álcool, iniciados antes dos 25 anos, foram denominados como bebedores de início precoce, e os que tiveram início dos problemas após 25 anos completos, foram chamados de bebedores de início tardio. A história familiar de alcoolismo foi dividida, conforme a presença de parentes de primeiro grau com problemas com álcool, em com e sem história de alcoolismo.

A regressão linear direta com um modelo completo, incluindo todas as variáveis e uma constante, mostrou ter significância estatística $\left(\chi^{2}=41,85,10\right.$ df, $p<0,01)$. A variância entre os membros dos grupos ocorreu de forma marginal (Nagelkerke $R^{2}=0,16$ ). A taxa de sucesso do modelo para prever foi de $65,1 \%$.

Neste modelo de regressão, o cluster tipo 2 permaneceu com elevado risco de descontinuar o tratamento, e a participação no grupo de mútua ajuda manteve o seu efeito, sobre a aderência ao tratamento (tabela 16). A verificação do ajuste do modelo foi realizada usando o teste de Lemeshow e Hosmer $\left(\chi^{2}=4,38,8 \mathrm{df}, p=0,82\right)$. 
Tabela 20. Efeito da medicação, participação no AA e variáveis relacionadas ao cluster, na retenção do tratamento.

\begin{tabular}{|c|c|c|c|c|c|c|}
\hline Variáveis & SE & Wald & df & $\mathbf{p}$ & OR & IC-95\% \\
\hline Constante & 0,48 & 1,74 & $\therefore$ & " 0,19 & 0,53 & $\because$ \\
\hline cluster tipo 2 & 0,27 & 9,16 & 1 & $<0,01$ & 0,45 & $0,26-0,75$ \\
\hline Grupo medicação & - & 3,83 & 4 & 0,43 & - & - \\
\hline Ondansetrona & 0,37 & 1,58 & 1 & 0,21 & 1,59 & $0,77-3,27$ \\
\hline Acamprosato & 0,44 & 1,39 & 1 & 0,24 & 1,68 & $0,71-3,98$ \\
\hline Naltrexona & 0,36 & 1,70 & 1 & 0,19 & 1,59 & $0,79-3,20$ \\
\hline Topiramato & 0,35 & 1,59 & 1 & 0,21 & 1,56 & $0,78-3,11$ \\
\hline Participação no AA & 0,34 & 11,39 & 1 & $<0,01$ & 3,19 & $1,63-6,25$ \\
\hline Parentes de $1^{\circ}$ grau $^{1}$ & 0,32 & $<0,01$ & 1 & 0,94 & 1,02 & $0,55-1,91$ \\
\hline Sintomas depressivos $^{2}$ & 0,25 & 3,67 & 1 & 0,06 & 0,62 & $0,38-1,01$ \\
\hline Gravidade alcoolismo $^{3}$ & 0,34 & 2,31 & 1 & 0,13 & 1,68 & $0,86-3,26$ \\
\hline Início precoce alcoolismo ${ }^{4}$ & 0,33 & 2,69 & 1 & 0,10 & 0,60 & $0,33-1,10$ \\
\hline
\end{tabular}

${ }^{1}$ Histórico de alcoolismo em parentes de primeiro grau; ${ }^{2}$ Presença de sintomas depressivos de leve-moderado, baseados na escala de depressão de Hamilton; ${ }^{3}$ Gravidade do alcoolismo, aferido pela SADD; ${ }^{4}$ Idade de início dos problemas com alcoolismo antes dos 25 anos. 


\subsection{Variáveis clínicas preditoras de adesão ao tratamento}

Para a análise de variáveis clínicas preditoras de retenção no tratamento, foram excluídos os participantes do estudo com acamprosato (75 indivíduos), porque neste ensaio clinico não foi realizada a avaliação da "fissura" pelo álcool. Foram incluídos na análise 257 sujeitos, com idade entre 23 e 60 anos (média de 43,8 anos, desvio padrão 8,92 anos). A maioria dos participantes era casada (56\%), da raça branca (56\%), não havia concluído o ensino médio (53\%) e consumia tabaco (69\%). Apenas $136(52,9 \%)$ sujeitos terminaram o tratamento proposto.

A comparação entre os participantes que terminaram ou não 0 tratamento proposto, está ilustrada na tabela 21. As diferenças, encontradas nessa comparação, foram: idade média no início do tratamento $(45,44$ anos nos aderentes e 41,88 anos nos desistentes, $t=3.26,255 \mathrm{df}, \mathrm{p}<0,01$ ); tipo de bebida preferencial (consumo preferencial de cerveja ocorreu em 33,1\% dos pacientes que terminaram o tratamento e em $21,5 \%$ dos que não 0 terminaram, $\chi^{2}=4.54,1 \mathrm{df}, \mathrm{p}=0.04$ ); o tipo de medicamento usado (ter usado o placebo foi uma condição encontrada em $33,1 \%$ dos aderentes e em $50,4 \%$ dos não aderentes, $\left.\chi^{2}=8.27,3 \mathrm{df}, \mathrm{p}=0.04\right)$; ainda, participar do AA (situação referida por $17,6 \%$ dos participantes que completaram o estudo e por $6,6 \%$ dos desistentes, $\chi^{2}=7.15,1 \mathrm{df}, \mathrm{p}<0.01$ ).

Foi realizada a análise de regressão logística direta, utilizando-se como desfecho o término ou não do tratamento ("aderentes" ou "não aderentes"). As variáveis testadas como preditoras foram: variáveis relacionadas ao tratamento, como grupo de medicação e participação nos alcoólicos anônimos; ainda, variáveis relacionadas ao sujeito, como intensidade da "fissura" pelo álcool (OCDS), gravidade do alcoolismo (SADD), sintomas depressivos (Hamilton-21), idade no início do tratamento, tempo desde o início do consumo regular de álcool, tempo desde o início dos problemas com o consumo de álcool, história familiar de alcoolismo, bebida preferencial, consumo de tabaco, quantidade de álcool consumida por dia (antes do início do tratamento), história de tratamento prévio para 
alcoolismo, raça, estado civil e situação financeira. Escolhemos este teste para minimizar as possíveis influências entre as variáveis estudadas.

Na regressão logística, a idade no início do tratamento, a participação no $A A$, o nível médio na escala de depressão (Hamilton-21) e a bebida preferencial foram as variáveis capazes de prever a aderência ao tratamento (tabela 22). O modelo usado mostrou ser estatisticamente confiável $\left(\chi^{2}=44,48,21 \mathrm{df}, p<0,01\right)$. A variância entre os membros dos grupos foi pequena (Nagelkerke $R^{2}=0,21$ ). $O$ modelo mostrou um sucesso para previsão de $65,8 \%$. O ajuste do modelo foi confirmado pelo teste de Lemeshow e Hosmer ( $\left.\chi^{2}=8,15,8 \mathrm{df}, p=0,42\right)$.

Usando apenas as variáveis associadas ao término do tratamento, foi realizada nova análise de regressão logística direta. Nesta nova análise, permaneceram como variáveis capazes de prever a aderência ao tratamento, somente a idade no início do tratamento, a participação no AA e os níveis médios na escala de depressão (Hamilton-21). A cerveja como bebida preferencial perdeu sua importância (tabela 19). A confiança do modelo foi testada e mostrou ser estatisticamente significante $\left(\chi^{2}=24,55,5\right.$ $\mathrm{df}, p<0,01)$. A variância entre os membros dos grupos ocorreu de forma marginal (Nagelkerke $R^{2}=0,12$ ). O modelo mostrou $65,4 \%$ capacidade para previsão. $\mathrm{O}$ ajuste desse modelo foi checado pelo teste de Lemeshow e Hosmer ( $\left.\chi^{2}=8,89,8 d f, p=0,35\right)$.

A "fissura" pelo álcool tem sido relacionada como um elemento, importante, associado à resposta ao tratamento. A análise de correlação entre a "fissura", medida pela OCDS, e outras variáveis aferidas no início do tratamento foi feita (Pearson, Phi e Poit-biserial, tabela 20). A "fissura" pelo álcool apresentou associação negativa com a idade do paciente no início do tratamento $(-0,22 ; p<0,01)$ e, também, com o estado civil "casado" $(-0,22$; $p<0,01)$. Os escores de "fissura" na OCDS apresentaram associação positiva com história familiar de alcoolismo $(0,20 ; p<0,01)$, com o consumo preferencial de destilado $(0,16 ; p<0,01)$, com a quantidade de álcool consumida $(0,37 ; p<0,01)$ e com a gravidade do alcoolismo medida pelo $\operatorname{SADD}(0,70 ; p<0,01)$. 
Tabela 21. Características dos pacientes eleitos para análise de variáveis preditoras de retenção no tratamento.

\begin{tabular}{|c|c|c|c|}
\hline Características & Aderentes $(n=136)$ & Não aderentes $(n=121)$ & 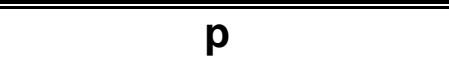 \\
\hline Idade, média (DP) & $45,44(8,52)$ & $41,88(9,01)$ & $\mathrm{t}=3,26,255 \mathrm{df}, \mathrm{p}<0,01^{* *}$ \\
\hline $\begin{array}{r}\text { Casado } \\
\text { Solteiro } \\
\text { Separado / Viúvo }\end{array}$ & $\begin{array}{l}77(56,6) \\
24(17,6) \\
35(25,8)\end{array}$ & $\begin{array}{l}67(55,4) \\
17(14,0) \\
37(30,6)\end{array}$ & $\chi^{2}=1,07,2 d f, p=0,59$ \\
\hline $\begin{array}{r}\text { Branca } \\
\text { Negra } \\
\text { Pardo }\end{array}$ & $\begin{array}{l}82(60,3) \\
20(14,7) \\
34(25,0)\end{array}$ & $\begin{array}{l}62(51,2) \\
13(10,7) \\
46(38,0)\end{array}$ & $\chi^{2}=5,20,2 d f, p=0,07$ \\
\hline Consumo de álcool por dia em gramas ${ }^{1} \mathrm{~m}(\mathrm{DP})$ & $299,92(163,59)$ & $295,34(194,38)$ & $t=0,21,255 d f, p=0,84$ \\
\hline $\begin{array}{l}\text { Tempo desde o início dos problemas com uso do } \\
\text { álcool, média (DP) }\end{array}$ & $11,33(8,82)$ & $11,04(9,47)$ & $t=0,25,255 d f, p=0,80$ \\
\hline Alcoolistas fumantes $\mathrm{n}(\%)$ & $95(69,9)$ & $82(67,8)$ & $\chi^{2}=0,13,1 d f, p=0,72$ \\
\hline História familiar de alcoolismo, n (\%) & $107(78,7)$ & $97(80,2)$ & $\chi^{2}=0,09,1 \mathrm{df}, \mathrm{p}=0,77$ \\
\hline Tratamento prévio para alcoolismo, n (\%) & $74(54,4)$ & $65(53,7)$ & $\chi^{2}=0,01,1 d f, p=0,91$ \\
\hline Renda mensal (em Reais), média (DP) & $1024,34(951,18)$ & $1158,97(1056,35)$ & $t=-1,07,255 d f, p=0,28$ \\
\hline \multicolumn{4}{|l|}{ Bebida preferencial $\mathrm{n}(\%)$} \\
\hline $\begin{array}{l}\text { Destilado } \\
\text { Cerveja } \\
\text { Vinho }\end{array}$ & $\begin{array}{c}89(65,4) \\
45(33,1) \\
2(1,5)\end{array}$ & $\begin{array}{c}94(77,7) \\
26(21,5) \\
1(0,8)\end{array}$ & $\chi^{2}=4,54,1 \mathrm{df}, p=\underset{0,04^{*}}{\text { continua }}$ \\
\hline
\end{tabular}




\section{Características}

Medicações

\begin{tabular}{|c|c|c|c|}
\hline $\begin{array}{c}\text { Medicações } \\
\text { Ondansetrona } \\
\text { Naltrexona } \\
\text { Topiramato } \\
\text { Placebo } \\
\end{array}$ & $\begin{array}{l}29(21,3) \\
29(21,3) \\
33(24,3) \\
45(33,1)\end{array}$ & $\begin{array}{l}21(17,4) \\
20(16,5) \\
19(15,7) \\
61(50,4)\end{array}$ & $\chi^{2}=8,27,3 \mathrm{df}, p=0,04^{*}$ \\
\hline $\begin{array}{l}\text { VCM sérico, f/L; média (DP) } \\
\text { (Valor de referencia 80-100) }\end{array}$ & $94,66(6,53)$ & $94,89(7,96)$ & $t=-0,25,255 d f, p=0,80$ \\
\hline $\begin{array}{l}\text { AST sérico, U/L; média (DP) } \\
\text { (Valor de referencia < 37) }\end{array}$ & $42,79(38,06)$ & $41,16(31,84)$ & $t=0,36,255 d f, p=0,72$ \\
\hline $\begin{array}{l}\text { ALT sérico, U/L; média (DP) } \\
\text { (Valor de referencia < } 41 \text { ) }\end{array}$ & $38,18(31,81)$ & $37,88(25,85)$ & $\mathrm{t}=0,08,255 \mathrm{df}, \mathrm{p}=0,94$ \\
\hline $\begin{array}{l}\text { GGT sérico, U/L; média (DP) } \\
\text { (Valor de referencia } 8 \text { - 61) }\end{array}$ & $141,86(268,77)$ & $147,60(238,99)$ & $\mathrm{t}=-0,18,255 \mathrm{df}, \mathrm{p}=0,86$ \\
\hline SADD, média (DP) & $25,51(8,07)$ & $27,99(8,54)$ & $\mathrm{t}=-0,47,255 \mathrm{df}, \mathrm{p}=0,64$ \\
\hline OCDS, média (DP) & $47,82(12,10)$ & $48,20(12,31)$ & $t=-0,25,255 d f, p=0,80$ \\
\hline Hamilton-21, média (DP) & $9,23(6,07)$ & $10,66(6,65)$ & $t=-1,81,255 d f, p=0,07$ \\
\hline Participação em AA, n (\%) & $24(17,6)$ & $8(6,6)$ & $\chi^{2}=7,15,1 d f, p<0,01^{\star *}$ \\
\hline
\end{tabular}

$(\mathrm{DP})$ = desvio padrão; $\mathrm{n}(\%)$ = número de sujeitos (porcentagem); ${ }^{1}=$ consumo médio de álcool por dia, expresso em gramas, calculado a partir do consumo dos três últimos meses antes do início do estudo; ${ }^{2}$ Escala de "fissura" OCDS, ou Obsessive Compulsive Drinking Scale; ${ }^{3}$ escala de gravidade de alcoolismo SADD, Short Alcohol Dependence Data; ${ }^{4}$ escala de Depressão Hamilton de 21 itens; ${ }^{5}$ GGT ou gama glutamil transpeptidase; ${ }^{6}$ ALT ou alanina aminotransferase; ${ }^{7}$ AST ou aspartato aminotransferase; ${ }^{8}$ VCM ou Volume corpuscular médio. 
Tabela 22. Efeito das variáveis clínicas e psicossociais na retenção do tratamento.

\begin{tabular}{|c|c|c|c|c|c|c|c|}
\hline \multicolumn{2}{|l|}{ Variáveis } & SE & Wald & $\mathrm{df}$ & $\mathrm{p}_{r, r}$ & $\underset{\therefore:}{\mathrm{OR}}$ & IC-95 \\
\hline \multicolumn{2}{|l|}{ Idade } & 0,02 & 4,96 & 1 & $0,02^{*}$ & 1,05 & $1,01-1,09$ \\
\hline \multirow[t]{3}{*}{ Raça } & Branca $^{R}$ & & & & & & \\
\hline & Negra & 0,45 & 0,11 & 1 & 0,74 & 1,16 & $0,48-2,81$ \\
\hline & Parda & 0,33 & 2,55 & 1 & 0,11 & 0,59 & $0,31-1,13$ \\
\hline \multirow[t]{3}{*}{ Estado civil } & Casado $^{\mathrm{R}}$ & & & & & & \\
\hline & Solteiro & 0,42 & 1,01 & 1 & 0,31 & 1,52 & $0,67-3,45$ \\
\hline & Separado/Viúvo & 0,34 & 0,89 & 1 & 0,34 & 0,73 & $0,37-1,41$ \\
\hline \multicolumn{2}{|c|}{ Consumo de álcool por dia (gramas) } & $<0,01$ & 3,62 & 1 & 0,06 & $>0,99$ & $0,99-1,01$ \\
\hline \multicolumn{2}{|c|}{ História de tratamento prévio de alcoolismo } & 0,29 & 0,13 & 1 & 0,72 & 1,11 & $0,63-1,95$ \\
\hline \multicolumn{2}{|c|}{ Renda mensal (em reais) } & $<0,01$ & 3,62 & 1 & 0,06 & $>0,99$ & $0,99-1,01$ \\
\hline \multirow[t]{3}{*}{ Bebida preferencial } & Destilados $^{\mathrm{R}}$ & & & & & & \\
\hline & Cerveja & 0,33 & 4,07 & 1 & $0,04^{*}$ & 1,95 & $1,02-3,75$ \\
\hline & Vinho & 1,32 & 0,72 & 1 & 0,39 & 3,07 & $0,23-41,04$ \\
\hline \multirow[t]{4}{*}{ Grupo de medicação } & Placebo $^{\mathrm{R}}$ & & & & & & \\
\hline & Ondansetrona & 0,40 & 2,85 & 1 & 0,09 & 1,96 & $0,90-4,30$ \\
\hline & Topiramato & 0,40 & 2,20 & 1 & 0,14 & 1,82 & $0,82-3,99$ \\
\hline & Naltrexona & 0,40 & 1,55 & 1 & 0,21 & 1,65 & $0,75-3,65$ \\
\hline \multicolumn{2}{|l|}{ Alcoolista fumante } & 0,32 & 0,30 & 1 & 0,58 & 1,19 & $0,64-2,23$ \\
\hline \multicolumn{2}{|l|}{ OCDS } & 0,02 & $<0,01$ & 1 & 0,95 & 0,99 & $0,97-1,03$ \\
\hline \multicolumn{2}{|l|}{ SADD } & 0,02 & $<0,01$ & 1 & 0,94 & 1,01 & $0,95-1,05$ \\
\hline \multicolumn{2}{|l|}{ Hamilton-21 } & 0,02 & 5,56 & 1 & $0,02^{*}$ & 0,95 & $0,90-0,99$ \\
\hline \multicolumn{2}{|l|}{ Participação no AA } & 0,48 & 5,70 & 1 & $0,02^{*}$ & 3,12 & $1,23-7,97$ \\
\hline \multicolumn{2}{|c|}{ Tempo desde o início do consumo do álcool } & 0,03 & 1,27 & 1 & 0,26 & 1,03 & $0,98-1,08$ \\
\hline \multicolumn{2}{|c|}{ Tempo desde o início dos problemas com o álcool } & 0,02 & 2,44 & 1 & 0,12 & 0,96 & $0,92-1,01$ \\
\hline
\end{tabular}

${ }^{*} \mathrm{p}<0,05 ;{ }^{\mathrm{R}}$ Variável usada como referência na regressão logística; OCDS, Obsessive Compulsive Drinking Scale; SADD, Short Alcohol Dependence Data; Hamilton-21, escala de Depressão Hamilton de 21 itens. 
Tabela 23. Análise de regressão logística apenas com variáveis que mostraram prever a retenção ao tratamento.

\begin{tabular}{|c|c|c|c|c|c|c|}
\hline Variáveis & $\overline{\mathrm{SE}}$ & Wald & $\overline{d f}$ & $p$ & $\overline{\mathrm{OR}}$ & IC-95 \\
\hline Idade & 0,02 & 9,16 & 1 & $<0,01$ & 1,05 & $1,01-1,09$ \\
\hline \multicolumn{6}{|l|}{ Bebida preferencial } & \\
\hline Cerveja & 0,30 & 3,52 & 1 & 0,06 & 1,75 & $0,98-3,15$ \\
\hline Vinho & 1,26 & 0,17 & 1 & 0,68 & 1,68 & $0,14-19,89$ \\
\hline Hamilton & 0,02 & 4,34 & 1 & 0,03 & 0,96 & $0,92-0,99$ \\
\hline Participação no AA & 0,45 & 5,03 & 1 & 0,02 & 2,73 & $1,13-6,55$ \\
\hline
\end{tabular}

Rariável usada como referência na regressão logística; Hamilton, escala de Depressão Hamilton de 21 itens. 
Tabela 24. Correlação das variáveis incluídas na análise multivariada.

\begin{tabular}{|c|c|c|c|c|c|c|c|c|c|c|c|c|c|c|}
\hline Variável & 1 & 2 & 3 & 4 & 5 & 6 & 7 & 8 & 9 & 10 & 11 & 12 & 13 & 14 \\
\hline 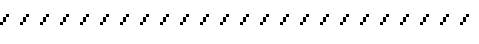 & M & $\therefore: \therefore:$ & a & $\therefore::$ & $\cos$ & 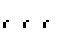 & $1+1$ & $\ldots \ldots$ & $\ldots$ & $\therefore:$ & $\ldots$. & 1 & $\therefore:$ & $\ldots$ \\
\hline $1-$ OCDS & - & & & & & & & & & & & & & \\
\hline 2 - Idade & $-0,22^{* *}$ & - & & & & & & & & & & & & \\
\hline 3 - Raça (branca) & ns & ns & - & & & & & & & & & & & \\
\hline 4 - História familiar & $0,20^{* *}$ & ns & ns & - & & & & & & & & & & \\
\hline $5-S A D D$ & $0,70^{* *}$ & $-0.22^{* *}$ & ns & $0,23^{* *}$ & - & & & & & & & & & \\
\hline 6 - Alcoolista tabagista & ns & ns & $0,13^{*}$ & ns & ns & - & & & & & & & & \\
\hline 7 - Tempo de consumo álcool ${ }^{1}$ & ns & $0,60^{* *}$ & ns & $0,14^{*}$ & ns & ns & - & & & & & & & \\
\hline 8 - Tempo de problemas com álcool $\left.\right|^{2}$ & ns & $0,40^{* *}$ & ns & ns & ns & ns & ns & - & & & & & & \\
\hline 09 - Bebida preferencial (destilado) & $0,16^{\star *}$ & ns & ns & ns & $0,23^{\star *}$ & ns & ns & ns & - & & & & & \\
\hline 10 - Consumo de álcool por dia & $0,37^{\star *}$ & $-0,19^{* *}$ & ns & $0,15^{\star}$ & $0,35^{\star *}$ & ns & $-0,18^{* *}$ & $-0,16^{*}$ & $0,15^{*}$ & - & & & & \\
\hline 11- Hamilton & ns & ns & ns & ns & ns & ns & $0,18^{* *}$ & $0,14^{*}$ & ns & ns & - & & & \\
\hline 12 - Estado civil (casado) & $-0,22^{* *}$ & $0,19^{\star *}$ & ns & ns & $-0,26^{* *}$ & ns & $0,14^{*}$ & ns & ns & ns & ns & - & & \\
\hline 13 - Renda mensal & ns & ns & ns & ns & ns & ns & ns & ns & $-0,14^{*}$ & ns & $-0,15^{\star}$ & ns & - & \\
\hline 14 - História tratamento prévio & ns & ns & ns & ns & ns & ns & ns & ns & ns & ns & $0,16^{\star \star}$ & ns & ns & - \\
\hline
\end{tabular}

$\mathrm{p}<0,05 ;{ }^{* \star} \mathrm{p}<0,01 ; \mathrm{ns}$ = não significativo; OCDS, Obsessive Compulsive Drinking Scale; SADD; Short Alcohol Dependence Data; Hamilton, Escala de depressão de Hamilton com 21 itens; ${ }^{1}$ Tempo de consumo de álcool = intervalo de tempo desde o início do consumo regular de álcool; ${ }^{2}$ Tempo de problemas com álcool = intervalo de tempo desde o início dos problemas com o consumo de álcool. 


\section{DISCUSSÃO}

\subsection{Discussão dos resultados do ensaio clínico com ondansetrona}

Nesta pesquisa, a ondansetrona, na dosagem de $16 \mathrm{mg} / \mathrm{dia}$, mostrouse mais efetiva que o placebo em aumentar o tempo para o primeiro consome de alcool e, também, para o primeiro episódio de consumo pesado de álcool. Dos pacientes selecionados, metade completou o estudo. Os fatores associados à adesão ao tratamento foram: idade mais elevada no início do tratamento e a condição de ser fumante. Entretanto, esse medicamento não foi capaz de influenciar o tempo total de dias abstinentes e a percentagem de dias abstinentes durante as 12 semanas de estudo. Após a análise de imputação, esse antagonista de $5-\mathrm{HT}_{3}$ foi mais efetivo que o placebo em diminuir a percentagem de dias com consumo pesado de álcool durante o estudo. Até o presente momento, este é o primeiro estudo randomizado, duplo-cego, placebo-controlado para avaliar a eficácia da ondansetrona na dose de $16 \mathrm{mg} / \mathrm{dia}$ para o tratamento de pacientes dependentes de álcool.

O efeito da ondansetrona reduzindo a "fissura" pelo álcool, provocando o aumento do tempo para o primeiro consumo de bebida alcoólica, já havia sido descrito em estudo prévio (Dawes et al., 2005). Contudo este foi a primeira evidência de que a ondansetrona em dose elevada pode também retardar o primeiro consumo de álcool.

O efeito da ondansetrona em reduzir o consumo de álcool nos dias bebidos, aumentando consequentemente, o tempo para o primeiro consumo pesado de álcool, já havia sido demonstrado em outros estudos (Kenna et al., 2009). O antagonista 5- $\mathrm{HT}_{3}$ atuaría bloqueando o reforço positivo causado pelo consumo da bebida, desencorajando o consumo de doses altas dessa substância (Johnson et al., 1993). Alguns estudos, também, motram sensações aversivas com o uso do alcool, quando em uso de doses altas de ondansetrona, 8mg/dia (Swift e al., 1996; Doty et al, 1994). 
Os principais problemas, deste estudo, estão relacionados com a elevada taxa de descontinuação do tratamento. Isso pode dificultar a adequada interpretação dos resultados. No entanto, é possível afirmar que nem a ondansetrona nem o placebo estiveram ligados a esses abandonos. Pacientes mais velhos têm sido associados a menores taxas de abandono (Graff et al., 2009; Oslin et al., 2002). Quanto ao efeito de fumar sobre a retenção de tratamento do alcoolismo, a literatura tem mostrado resultados conflitantes. De qualquer forma, o tabagismo pode ter alguma capacidade de ajudar os alcoolistas a enfrentarem o desejo de beber (Schmidt e Smolka, 2007) e, consequentemente, aumentar a adesão ao tratamento da dependência do álcool. Algumas pesquisas clínicas e experimentais têm sugerido que dependentes tabagistas podem estar interessados na cessação do tabagismo, mas preferem tratar a dependência de álcool, antes de tentar parar de fumar, dada a dificuldade em parar as duas drogas ao mesmo tempo (Baltieri et al., 2009; Joseph et al., 2004; Ellingstad et al., 1999).

As altas taxas de descontinuação do tratamento também foram observadas em outros ensaios farmacológicos para o alcoolismo (Baltieri et al., 2008; Johnson et al., 2007; Kranzler et al., 1996). A ineficácia dos recursos terapêuticos e a elevada gravidade da dependência de álcool têm sido associadas com a alta taxa de abandono ao tratamento da síndrome de dependência do álcool. Alguns autores têm proposto formas de minimizar o efeito do abandono ao tratamento dos pacientes em ensaios clínicos. Um método óbvio seria informar e educar os pacientes e investigadores, sobre as características dos programas de investigação, antes do início do acompanhamento. Outro método seria o de considerar os critérios de elegibilidade, a fim de excluir os pacientes com maior risco de não completar o estudo (Myers, 2000). Certamente, esta última proposta levanta uma série de questões éticas e de aplicabilidade clínica dos ensaios realizados. As informações sobre as características dos pacientes ligadas ao abandono ou desistência do tratamento devem ser usadas para melhorar os programas de tratamento para dependência de álcool, tornando-os mais eficazes e 
atraentes, combinando agentes farmacológicos e diversas modalidades de intervenções psicossociais. Determinadas abordagens, como a terapia comportamental cognitiva e entrevista motivacional, podem ser boas opções quando combinadas com intervenções farmacológicas para ensaios clínicos randomizados (Heffner et al., 2010). Estratégias para melhorar a motivação dos participantes são de suma importância em programas de tratamento de dependentes de álcool.

A ondansetrona teve um perfil de efeitos colaterais favorável. Neste estudo, embora os efeitos adversos mais comuns da ondansetrona tenham sido dispepsia e constipação, não houve diferenças entre os dois grupos de medicamentos. Pode-se presumir que a ondansetrona, na dose de $16 \mathrm{mg} / \mathrm{dia}$, pode ter colaborado para as altas taxas de evasão, neste estudo. Apesar disso, os efeitos colaterais relatados não foram diferentes entre os grupos placebo e ondansetrona. Além disso, outros estudos sobre a eficácia da ondansetrona para tratar os sintomas de depressão e ansiedade (concomitantes ou mesmo derivados de outras doenças) testaram com sucesso doses altas de ondansetrona, entre 8 e $24 \mathrm{mg}$ diários, mostrando redução nos sintomas depressivos (Faris et al., 2006; Harmer et al., 2006; Piche et al., 2005), diminuição da ansiedade em indivíduos com transtorno obsessivo-compulsivo (Soltani et al., 2010), e, até mesmo, melhora em alterações cognitivas em pacientes esquizofrênicos (Akhondzadeh et al., 2009; Bennett e Vila, 2010). Em outro estudo, a ondansetrona na dosagem de $8 \mathrm{mg}$ (mas não na dosagem de $4 \mathrm{mg}$ ) mostrou ser útil para diminuir os sinais de abstinência a opiáceos (Chu et al., 2009; Sell et al., 1995).

A dose da ondansetrona para o tratamento do alcoolismo não está completamente esclarecida principalmente porque esse fármaco, dependendo da dose, parece ter efeito diferente para os diferentes tipos de alcoolistas. Para bebedores de início precoce, já foi observada curva doseresposta, não retilínea, em forma de U-invertida, com a oferta de $4 \mathrm{mcg} / \mathrm{kg}$ duas vezes ao dia de ondansetrona, sendo melhor do que uma dose maior $(16 \mathrm{mcg} / \mathrm{kg}$ duas vezes ao dia) ou uma dose menor $(1 \mathrm{mcg} / \mathrm{kg}$ duas vezes ao dia) (Johnson et al., 2000c; Kranzler et al, 2003). Além disso, é importante 
notar que a ondansetrona exibe penetrabilidade relativamente pobre no sistema nervoso central de humanos e a concentração do psicofármaco no fluido cerebroespinhal corresponde a menos de $15 \%$ da observada no sangue (Simpson et al., 1992), tornando ainda mais difícil definir a dose ideal dessa medicação, para o tratamento dos alcoolistas. Além disso, alguns pesquisadores têm demonstrado que a ondansetrona, aparentemente, é menos eficaz para tratar os bebedores pesados do que os bebedores leves, e a amostra deste estudo eram compostos principalmente por sujeitos com elevada dependência de álcool (Sellers et al, 1994).

Alguns estudos têm mostrado que a ondansetrona é significativamente mais eficaz para dependentes de álcool portadores do genótipo LL, para o polimorfismo ligado ao gene transportador de serotonina (5'-HTTLPR), comparado aos outros dois genótipos SS e LS (Kenna et al., 2009). Assim, somente os alcoolistas com constituição alélica específica para o gene transportador de serotonina (5-HTT) têm sido beneficiados com o sucesso no tratamento com ondansetrona, independente da idade de início dos problemas com o uso do álcool. Alguns estudos realizados em nossa população têm mostrado uma frequência baixa do alelo $S$, e a ocorrência do genótipo SS foi encontrada em $21,4 \%$ da população (Abdo et al. 2012; Meira-Lima et al., 2005; Mendes de Oliveira et al., 1998). Essas taxas tão pequenas se devem à alta miscigenação de raças presente no Brasil (Parra et al, 2003). Pode ser que em nosso estudo tenha ocorrido baixa frequência de pessoas com o genótipo SS, o que explicaria a ausência de efeito da ondansetrona em reduzir a proporção de dias abstinentes e a pequena influência encontrada na proporção de dias com consumo pesado de álcool, resultados normalmente associados ao uso deste fármaco.

Como os dados faltantes dos pacientes desligados não foram perdidos ao acaso (não caracterizando uma perda randômica), usando as duas variáveis, que foram significativamente associadas com a descontinuação do tratamento, foi realizada a imputação múltipla, a fim de avaliar toda a amostra. Depois disso, houve uma diferença significativa entre os dois grupos de medicamentos em termos de percentagem de dias com 
consumo pesado de álcool. Além disso, os alcoolistas de início tardio mostraram menor porcentagem de dias com consumo pesado que os alcoolistas de início precoce, independentemente do medicamento usado. Isto pode ser reflexo mais de características de um destes tipos de alcoólicos do que o efeito de um tipo específico de tratamento.

Como mencionado anteriormente, dependentes de álcool são uma população heterogênea e, provavelmente, o desenvolvimento contínuo de tipologias deve contribuir para determinar que tipo de tratamento farmacológico será mais eficaz, para cada tipo de paciente. A aplicabilidade das tipologias existentes na prática clínica diária ainda tem sido modesta. De qualquer forma, mais pesquisas sobre os tipos de alcoolistas que poderiam se beneficiar de doses baixas ou altas de ondansetrona devem ser estimuladas. Infelizmente, o estudo não foi capaz de mostrar qualquer efeito da tipologia de início precoce e tardio de alcoolista nos resultados do tratamento. 


\subsection{Discussão dos resultados da formulação da tipologia}

Quando os indivíduos foram divididos em dois grupos tipológicos, verificou-se que o cluster tipo 2 era formado por pessoas caracterizadas por menor idade de início dos problemas com o consumo de álcool, maior carga familiar de alcoolismo, maior gravidade do alcoolismo e menos sintomas depressivos do que os sujeitos pertencentes ao tipo 1. Os alcoolistas do cluster 2, também, mostraram maior chance de interrupção do tratamento, independentemente das diferentes medicações utilizadas e da participação no grupo dos Alcoólicos Anônimos (AA). Além disso, a participação na $A A$ foi um fator significativo em relação à retenção no tratamento dos alcoolistas, independentemente de qual tipo o alcoolista pertencia e dos medicamentos utilizados. A tipologia e a participação em AA mantiveram-se significantes em relação à retenção no tratamento, mesmo após serem controladas as outras variáveis, como: a tipologia de alcoolista, início precoce versus início tardio; ter ou não ter parentes de primeiro grau afetados pelo alcoolismo; ter ou não sintomas leves de depressão; presença de dependência de álcool moderada ou grave. Considerando as diversas classificações de alcoolistas já feitas, a nossa tipologia parece ser semelhante à proposta por Babor et al. (1992).

É importante notar que, apesar da elevada gravidade da dependência de álcool, a amostra é relativamente "benigna", uma vez que não existiam participantes com outros problemas psiquiátricos importantes, como abuso de outras drogas e depressão com sintomatologia grave. Além disso, devemos ter em mente que apenas $21 \%$ dos nossos participantes eram bebedores de início precoce, que pode ter prejudicado o efeito deste subgrupo sobre a retenção no tratamento, principalmente quando nossa amostra foi categorizada em bebedores de início precoce versus tardio.

De qualquer forma, o alcoolismo é uma doença multifatorial, envolvendo interações biológicas, genéticas e psicossociais. Assim, múltiplas variáveis podem ser necessárias para classificar esta população extremamente complexa, a fim de evitar a sobreposição das características, 
pelo menos em alguma extensão. É reconhecido que os indivíduos classificados pela tipologia de Cloninger I ou II, ou pelos tipos A ou B de Babor representam subgrupos heterogêneos e uma sobreposição de sintomas e das características pode ser vista entre os tipos. No entanto, o peso de fatores genéticos e neurobiológicos parece diferenciar-se, levando a diferentes respostas terapêuticas (Rubio et al., 2005).

Diversos estudos já tentaram identificar variáveis relacionadas ao paciente e ao tratamento, que sejam preditoras de melhor aderência ao tratamento dos dependentes de álcool. Há alguma evidência de que os seguintes fatores ligados aos sujeitos estão relacionados à interrupção precoce do tratamento: pacientes jovens e solteiros, com alta gravidade do uso da substância e falta de estabilidade familiar. Com relação aos fatores ligados ao tratamento, a aliança terapêutica positiva, a experiência clinica do médico e a participação pró-ativa de membros da família, têm sido associadas a menores taxas de abandono (Graff et al., 2009). Por outro lado, estudos têm mostrado resultados conflitantes em relação aos sintomas de depressão (Charney et al., 1998). É importante ressaltar que nenhum participante mostrou sintomas depressivos graves ou necessitou de tratamento específico para depressão, nesse estudo, dado que a depressão foi critério de exclusão para os três ensaios clínicos. Como regra geral, a qualidade do programa de tratamento, a motivação do paciente e suas características individuais podem contribuir para melhores taxas de retenção no tratamento.

O uso de medicamentos ativos não influenciou a retenção no tratamento neste estudo. Apesar disso, o grupo acamprosato teve um efeito melhor (mas não significativo) sobre o término do tratamento. Apesar da interação entre tipologia 1 e o grupo acamprosato ter sido estatisticamente significativa, o intervalo de confiança foi muito amplo, tornando pouco confiável a interpretação do efeito dessa interação sobre a retenção no tratamento. Outros estudos já demonstraram que os tratamentos com antagonistas opioides (Heinala et al., 2001; Srisurapanot et al., 2005; Rosner et al., 2010), com o topiramato (Johnson et al., 2007; Rubio et al., 2009) e 
com a ondansetrona, sozinhos ou em combinação com a naltrexona (Johnson, 2000a; Johnson et al., 2000c; Ait-Daoud et al., 2001) não estão associados a maior retenção no tratamento, quando comparados com placebo. Por outro lado, o tratamento com o acamprosato já foi associado com a maior adesão ao tratamento de alcoolistas, em relação ao placebo, quando os participantes estão abstinentes por mais de 4 dias antes do início da medicação (Kampmam et al., 2009). De qualquer forma, até mesmo a associação de dois psicofármacos para o alcoolismo não demonstram qualquer efeito sobre a permanência dos pacientes no tratamento, em comparação com qualquer tipo de farmacoterapia individual sozinha (Anton et al., 2006; Pettinati et al., 2010).

Neste estudo, a participação no AA esteve associada a maior retenção no tratamento. Até o momento, não há nenhuma evidência científica conclusiva de que a participação nos grupos de mútua ajuda mantém os pacientes por mais tempo no tratamento (Ferri et al., 2006). Em geral, a dificuldade de avaliar a eficácia da participação no AA é o viés da auto seleção daqueles que participam do grupo de mútua ajuda (Tonugan et al., 1996). Como a participação no AA foi incentivada, os sujeitos acabaram se indicando para participar do $A A$, um viés também conhecido como viés de seleção. Ainda, não está claro se há uma personalidade ou fatores motivacionais relacionados com a maior aderência ao grupo de mútua ajuda. Alguns autores relatam que os alcoolistas, que participam do AA, são tipicamente mais sociáveis, sentem-se culpados por comportamentos passados, são fisicamente mais saudáveis e socialmente estáveis (Emrick, 1987). Por outro lado, outros autores afirmam que os atendimentos no AA são mais comuns entre grupos raciais e étnicos minoritários, aqueles com menor renda, e com emprego instável (Humphreys et al., 1998). Embora essa generalização possa ser problemática e duvidosa, algumas características atribuídas aos participantes do AA podem ter certo nível de aceitabilidade, dadas as características inerentes à autoajuda. Na verdade, a participação no AA não era uma condição obrigatória para participar dos ensaios clínicos, apesar do incentivo dado a todos os dependentes, pelos 
pesquisadores. Isso pode significar que os pacientes mais motivados e afiliativos decidiram pela participação no AA, com o objetivo de melhorar as suas habilidades de enfrentamento e alterando as suas redes de amizade (Humphreys et al., 1999). Outros autores sugerem que o sucesso no AA está associado à presença frequente e contínua, e não à motivação em si (Fiorentine e Hillhouse, 2000).

A despeito da heterogeneidade dos alcoolistas, muitos programas terapêuticos oferecem um único tipo de tratamento. Como estes modelos focam uma única linha de tratamento, as variações na retenção ao tratamento acabam comumente sendo atribuídas aos fatores ou características relacionadas aos sujeitos. Embora isso possa ser verdade em certa medida, serviços de saúde devem ampliar o escopo dos serviços oferecidos para atender às necessidades, muitas vezes heterogêneas, dos clientes e identificar as práticas terapêuticas e os profissionais de saúde com potencial para melhorar a aderência ao tratamento. As informações sobre as características dos pacientes, relacionadas com a má aderência ao tratamento, devem ser usadas para fazer programas de tratamento mais atraentes, combinando agentes farmacológicos com intervenções psicossociais mais efetivas. Determinadas abordagens, como o treinamento de habilidades sociais e a entrevista motivacional, podem ser boas opções quando combinadas a intervenções farmacológicas para ensaios clínicos randomizados (Heffner et al., 2010). Estratégias, para melhorar a motivação, são de suma importância em diferentes programas de tratamento e devem ser levadas em conta para futuras pesquisas, nesta área.

Provavelmente, o contínuo desenvolvimento de tipologias contribuirá para determinar qual o tratamento é mais adequado para determinados tipos de alcoolistas, os profissionais de saúde poderão dar maior atenção à identificação do tipo de alcoolista e, a partir disso, escolher qual a melhor opção terapêutica para cada caso. Com base nesta informação, é possível identificar qual população necessita receber maior atenção e investimento para realizar o tratamento de dependência de álcool. 


\subsection{Discussão dos resultados da análise de variáveis clínicas preditoras de retenção no tratamento}

O resultado desta análise suporta evidências anteriores de que a "fissura" pelo álcool está positivamente correlacionada com o histórico famíliar de alcoolismo, com a gravidade da dependência e com a quantidade de álcool consumida por dia, mas negativamente associada com a idade do paciente. Além disso, a "fissura" pelo álcool foi positivamente correlacionada com os alcoolistas que preferem beber destilados. $O$ aumento da idade, menores escores de depressão, preferência por cerveja e frequentar o AA previram maior adesão ao tratamento. Contrariamente à hipótese inicial, a variável '"fissura"' (medida pelos OCDS no início do tratamento) não foi um fator capaz de prever a retenção de tratamento.

Estudos prévios, em pacientes com comportamentos impulsivos, já demostraram a diminuição dos sintomas impulsivos e compulsivos como aumento da idade e isso também parece ser verdade entre alcoolistas (Hintzen et al., 2011). De fato, a redução progressiva do consumo diário de álcool (Zhang et al., 2008), o decréscimo na neurotransmissão do sistema mesolímbico, as alterações do eixo hipotálamo-pituitária-adrenal (HPA) (Munro et al., 2005) e do eixo tiroide-hipotálamo (Leggio et al., 2008) têm sido propostos como mecanismo causal possível para a redução da "fissura" com o aumento da idade. Paralelo a isso, há alguma evidência de que a idade mais avançada pode prever melhor adesão ao tratamento do alcoolismo (Atkinson et al., 2003).

Nesta análise, os escores mais altos de depressão previram a interrupção precoce do tratamento. Apesar disso, pesquisas têm mostrado resultados contraditórios quanto à relação entre sintomas de depressão e a retenção no tratamento (Charney et al., 1998). De qualquer forma, é importante notar que a depressão se correlacionou positivamente com o maior intervalo de consumo de bebida alcoólica e com a história mais frequente de tratamento prévio para o alcoolismo. $\mathrm{Na}$ verdade, as experiências negativas com os tratamentos anteriores podem ter impacto 
negativo sobre a aceitação de ajuda para os problemas com o álcool. A consciência de que uma experiência anterior foi negativa pode mudar poderosamente os resultados comportamentais e clínicos (Porro, 2009). Também é importante ressaltar que nenhum participante estava gravemente deprimido ou requereu tratamento específico para depressão no estudo, dado que a depressão era um critério de exclusão para ambos os ensaios.

Bebedores preferenciais de cerveja apresentam maiores taxas de retenção no tratamento do que bebedores preferenciais de destilado e vinho. Este achado é diferente de outros estudos que verificaram maior niveis de "fissura" entre os bebedores preferenciais de cerveja, provavelmente devido à ingestão de maior volume de cerveja do que de outras bebidas (Hillemarcher et al., 2005). No entanto, a influência de diferentes tipos de bebidas na "fissura" e na adesão ao tratamento pode ser um subproduto de diversas variáveis de confusão, tais como fatores culturais e socioeconômicos. Embora a ingestão de um volume maior de bebida entre os bebedores de cerveja possa estar relacionada à intensidade da "fissura", principalmente devido à sua influência sobre o volume-regulação de peptídeos, os bebedores de destilados podem consumir maior quantidade de etanol por dia do que os bebedores de cerveja. A "fissura" pelo álcool também está associada com a quantidade diária de etanol consumido e com a gravidade da dependência do álcool (Baltieri et al., 2009b). Nesse estudo, as correlação entre essas duas variáveis (gravidade do alcoolismo e da quantidade de etanol) for positiva e significativa.

Estudos mostram que alcoolista que participa do AA está associado a maior chance de sucesso; contudo, a real influência desse grupo não é conhecida (Ferri et al., 2006; Tonigan et al., 1996). Em nosso estudo, procurar ajuda desse grupo esteve significativamente relacionado à retenção no tratamento. Os medicamentos testados não influenciaram na adesão ao tratamento, fato verificado em outros estudos (Johnson et al., 2007; Heinala et al, 2001; Ait-Doud et al., 2001).

Embora a "fissura" seja um fator importante a ser medido e investigado no início e durante o tratamento, este estudo não foi capaz de 
demonstrar que ela seja um fator de previsão de retenção no tratamento, pelo menos quando a intensidade de desejo é avaliada apenas no início do tratamento. $\mathrm{Na}$ realidade, a "fissura" não é uma condição estável, ela depende de outras variáveis que podem ser modificadas durante 0 tratamento, tais como o humor, o estresse, o consumo da substância e fatores ambientais. De qualquer forma, outras variáveis significativamente correlacionadas com a vontade, como a idade do paciente e a bebida preferencial, foram significativamente associadas com a retenção no tratamento.

Este estudo possui algumas limitações, entre elas: não houve outras abordagens psicossociais associadas com os tratamentos farmacológicos testados; o número de desistência foi elevado em ambos os estudos; não houve qualquer ação para melhorar a adesão ao tratamento; apesar do desenho dos ensaios clínicos minimizarem as influências externas, essa influência pode ter dificultado a interpretação dos resultados; o serviço donde estes estudos foram feitos é terciário, com encaminhamento de casos graves, como verificado pelo consumo pesado de álcool, descrito pelos pacientes; o estudo não incluiu mulheres, o que pode ter afetado a avaliação da retenção no tratamento e a "fissura", devido à diferença de gênero sobre estas; esse estudo não verificou o envolvimento dos o $\mathrm{AA}$, indicador mais adequado para reconhecer os sujeitos que aderiram aos métodos do AA; apesar da "fissura" pelo álcool ter sido realizada em três momentos (início, meio e fim do seguimento), foram usados para análise apenas os dados do início do tratamento. 


\section{CONCLUSÕES}

A ondansetrona, $16 \mathrm{mg}$ por dia, mostrou ser mais efetiva que 0 placebo para o tratamento de dependentes de álcool, em termos de aumentar o tempo para o primeiro consumo de qualquer quantidade de bebida alcoólica, e, ainda, para o primeiro episódio de consumo pesado de álcool. Entretanto, não foi possível mostrar qualquer efeito dela sobre o tempo total de abstinência e sobre percentagem de dias abstinentes. Como a amostra não foi grande o suficiente e a taxa de abandono do ensaio foi elevada, o estudo deixa, ainda, certo grau de dúvida sobre a eficácia da ondansetrona, nesta dose, em reduzir a proporção de dias bebidos pesados durante o tratamento.

Com o uso de quatro variáveis (história de alcoolismo familiar, a idade de início dos problemas com o consumo de álcool, intensidade dos sintomas depressivos e a gravidade do alcoolismo) foi possível desenvolver uma tipologia para dependentes de álcool capaz de identificar os alcoolistas com maior risco de abandonar o tratamento. Estes sujeitos mais propensos a abandonar o tratamento seriam caracterizados pelo início precoce dos problemas com álcool, maior carga familiar de alcoolismo, maior gravidade do alcoolismo e menor intensidade dos sintomas depressivos. O uso dessa tipologia pode ser benéfico para serviços de saúde que atendam dependentes de álcool, servindo para identificar os sujeitos com maior risco de abandono do tratamento, ou seja, que vão requerer maior investimento de recursos terapêuticos.

Foi possível identificar que o uso de psicofármacos (ondansetrona, acamprosato, topiramato e naltrexona) não influencia a maior aderência ao tratamento para o alcoolismo, ratificando a importância do atendimento desses pacientes ser feito com a combinação dos vários recursos terapêuticos disponíveis.

Algumas características clínicas isoladas como a idade mais elevada do alcoolista, menores níveis de depressão, preferência por consumir cerveja e a voluntária participação no AA são capazes de prever maior 
aderência dos pacientes ao tratamento da dependência de álcool. Entretanto, a relação entre a participação voluntária no grupo do AA e a aderência ao tratamento parece estar mais ligada a características pessoais dos voluntários, que escolhem participar do $\mathrm{AA}$, do que ao grupo de mútua ajuda em si. 


\section{Anexo A (Carta aprovação do CAPPesq)}

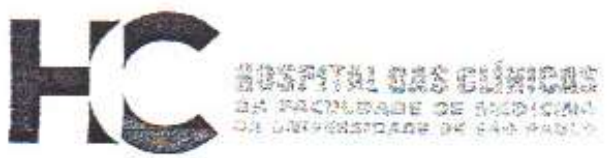

\section{APROVAÇĀO}

A Comissão de Ética para Análise de Projetos de Pesquisa - CAPPesq da Diretoria Clínica do Hospital das Clínicas e da Faculdade de Medicina da Universidade de São Paulo, em sessão de 22/08/2007, APROVOU o Protocolo de Pesquisa $n^{\circ}$ 0356/07, intitulado: "EFICÁCIA DA ONDANSETRONA NO TRATAMENTO DE DEPENDENTES DE ÁlCOOL" apresentado pelo Departamento de PSIQUIATRIA, inclusive o Termo de Consentimento Livre e Esclarecido.

Cabe do pesquisador elaborar e apresentar à CAPpesq, os relatórios parciais e final sobre a pesquisa (Resolução do Conselho Nacional de Saúde $n^{\circ} 196$, de 10/10/1996, inciso IX.2, letra "c").

Pesquisador (a) Responsável: Prof. Dr. Danilo Antonio Baltieri

Pesquisador (a) Executante: Joao Maria Corrêa Filho

CAPpesq. 27 de Agosto de 2007
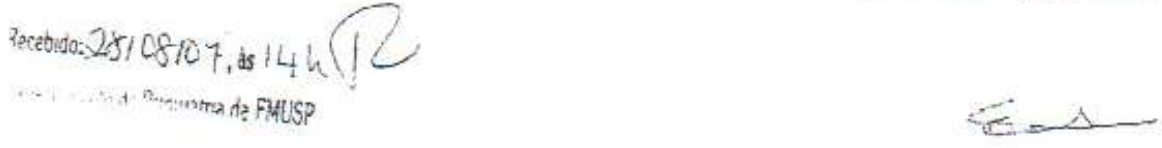

Prof. Dr. Eduardo Massad Presidente da Comissão de Ética para Análise de Projetos de Pesquisa

Comiss so de Etica para Analise de Projetos de Pesquasa de HCFMUSP e de FMUSP Diretone Clinica do Hospinai das Clinicas da Facuidade de Medicina da Universidacte de São Pauto Rua Ovidio Pires de Campoe, 255, 5" andar - CEP 05403 010 - 5a0 Paulo - SP Fone 011 3069

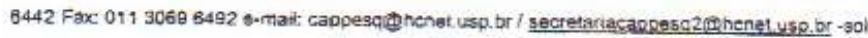




\section{Anexo B (Termo de consentimento pós-informação)}

\section{HOSPITAL DAS CLÍNICAS DA FACULDADE DE MEDICINA DA \\ UNIVERSIDADE DE SÃO PAULO}

\section{TERMO DE CONSENTIMENTO PÓS-INFORMAÇÃO}

\section{DADOS DE IDENTIFICAÇÃO DO SUJEITO DA PESQUISA OU RESPONSÁVEL LEGAL}

1. Nome do Paciente:

Documento de Identidade No:

Sexo: $M \square F \square$

Data de Nascimento:

..................

Endereço:

Bairro:

CEP:

Telefone:

Cidade:

2. Responsável Legal:

Natureza (grau de parentesco, tutor, curador etc.)

Documento de Identidade:

Data de Nascimento:

Sexo: $M \square F$

Endereço:

Bairro:

Cidade:

CEP:

Telefone: (........).....

\section{DADOS SOBRE A PESQUISA CIENTÍFICA}

1. TÍTULO DO PROTOCOLO DE PESQUISA: Eficácia da Ondansetrona no tratamento de dependentes de álcool.

2. PESQUISADOR: Danilo Antonio Baltieri / João Maria Corrêa Filho

3. Cargo/Função: Médico Psiquiatra / Médico Psiquiatra

4. Inscrição Conselho Regional No: 87745 / 114329

5. Unidade do HCFMUSP: Grupo Interdisciplinar de Estudos de Álcool e Drogas do Instituto de Psiquiatria do Hospital das Clínicas da Faculdade de Medicina da Universidade de São Paulo (GREA-IPq-HC-FMUSP)

6. Avaliação do Risco da Pesquisa:

Sem risco $\square \quad$ Risco Mínimo \# Risco Médio $\square \quad$ Risco Baixo $\square$

Risco Maior $\square$

(probabilidade de que o indivíduo sofra dano como consequência imediata ou tardia do estudo)

7. Duração da Pesquisa: 02 anos

\section{REGISTRO DAS EXPLICAÇÕES DO PESQUISADOR AO PACIENTE OU SEU REPRESENTANTE LEGAL SOBRE A PESQUISA, CONSIGNANDO:}

1. justificativa e os objetivos da pesquisa; 2. procedimentos que serão utilizados e propósitos, incluindo a identificação dos procedimentos que são experimentais; 3. desconfortos e riscos esperados; 4 . benefícios que poderão ser obtidos; 5 . procedimentos alternativos que possam ser vantajosos para o indivíduo; 6 . participação voluntária/ término da participação/ custos/ confidencialidade. 


\section{JUSTIFICATIVA E OBJETIVOS DA PESQUISA:}

O senhor (a) está sendo convidado a participar de uma pesquisa que objetiva determinar a eficácia e segurança da ondansetrona, no tratamento da dependência de álcool (alcoolismo). Este medicamento já foi utilizado no tratamento do alcoolismo em outros serviços que existem no mundo. Outras drogas como o antietanol, acamprosato, topiramato, naltrexona e antidepressivos também costumam ser utilizados no tratamento da dependência de álcool. A ondasetrona é utilizada em todo o mundo como antiemético (para tratar vômitos e náusea) e tem sido testada no tratamento de alcoolistas em alguns locais, como por exemplo, nos Estados Unidos, com resultados satisfatórios e com poucos efeitos colaterais.

\section{PROCEDIMENTOS QUE SERÃO UTILIZADOS E PROPÓSITOS DESSA UTILIZAÇÃO}

Antes de iniciar o tratamento, o senhor será submetido a uma avaliação médica para determinar se está qualificado a participar da presente pesquisa. Essa avaliação consiste no exame médico, aplicação de entrevistas estruturadas e coleta de sangue para análise. Mulheres que pretendam engravidar não poderão participar do estudo, porque a medicação ondansetrona não é recomendada para ser utilizada durante a gravidez.

\section{DESCONFORTOS E RISCOS ESPERADOS}

Os estudos clínicos envolvem, muitas vezes, alguns desconfortos aos pacientes, seja por causa do próprio remédio ou por causa dos procedimentos necessários na monitorização da sua resposta ao tratamento. O senhor deverá tomar 2 cápsulas do remédio por dia durante 3 meses aproximadamente. Os estudos já realizados em outros centros de pesquisa fora do Brasil apontam muito poucos efeitos colaterais. Os efeitos colaterais mais citados, atribuídos, a ondansetrona são: cefaleia, sintomas gastrintestinais como constipação e diarreia, febre, mal estar, aumento transitório de transaminases, rubor ou calor facial e raramente reações de hipersensibilidade.

\section{BENEFÍCIOS QUE PODERÃO SER OBTIDOS}

Sua participação neste estudo poderá ser muito benéfica para o senhor, porque ondansetrona é uma medicação avaliada em outros centros de tratamento, com resultados bastante promissores e satisfatórios e muito poucos efeitos colaterais. Este estudo poderá, também, contribuir para o desenvolvimento desse tratamento no nosso país.

\section{PROCEDIMENTOS ALTERNATIVOS AO USO DA ONDANSETRONA QUE POSSAM BENEFICAIR O PACIENTE:}

O senhor não precisa fazer parte desse estudo para ser tratado. Existem outras abordagens que podem ser usadas para tratar o alcoolismo, desde um tratamento psicoterapêutico até o uso de outras medicações, como o antietanol e antidepressivos. Seu médico discutirá com o senhor os tratamentos alternativos a ondansetrona para o seu caso. 
A sua participação nesse estudo é totalmente voluntária, e o senhor tem a possibilidade de interromper sua participação a qualquer momento, não havendo nenhum tipo de penalidade ou perda de benefícios caso isso ocorra.

Não haverá qualquer custo econômico para o senhor; a medicação será fornecida sem qualquer ônus. Seu médico tratará sua identidade com os padrões profissionais de confidencialidade. Assim, os dados do prontuário permanecerão confidenciais. Os nomes dos participantes não serão identificados em nenhuma publicação que possa resultar do presente estudo.

\section{ESCLARECIMENTOS DADOS PELO PESQUISADOR SOBRE GARANTIAS DO} SUJEITO DA PESQUISA:

1. acesso, a qualquer tempo, às informações sobre procedimentos, riscos e benefícios relacionados à pesquisa, inclusive para dirimir eventuais dúvidas;

2. liberdade de retirar seu consentimento a qualquer momento e de deixar de participar do estudo, sem que isto traga prejuízo à continuidade da assistência;

3. salvaguarda da confidencialidade, sigilo e privacidade;

4. disponibilidade de assistência no HCFMUSP, por eventuais danos à saúde, decorrentes da pesquisa;

5. viabilidade de indenização por eventuais danos à saúde decorrentes da pesquisa.

Após ler o termo de consentimento, declaro estar de acordo:

Nome do paciente ou responsável legal 


\section{Anexo C (Exames laboratoriais realizados durante o estudo)}

Exames Laboratoriais que fizeram parte da rotina da avaliação/ acompanhamento de pacientes com dependência de álcool.

$\checkmark$ Hemograma completo (VCM - Volume Corpuscular Médio)

$\checkmark$ Coagulograma (Tempo/atividade protrombina)

$\checkmark$ Gama Glutamil Transpeptidase Sérica (GGT)

$\checkmark$ Aspartato Aminotransferase Sérica (AST)

$\checkmark$ Alanina aminotransferase Sérica (ALT)

$\checkmark$ Bilirrubina Total e Frações Séricas

$\checkmark$ Ureia Sérica

$\checkmark$ Creatinina Sérica

$\checkmark$ Sódio Sérico

$\checkmark$ Potássio Sérico 
Anexo D (Critérios diagnósticos para síndrome de dependência de álcool)

CLASSIFICASSÃO INTERNACIONAL DE DOENÇAS - 10 EDIÇÃO

(Organização Mundial de Saúde, 1992)

Um forte desejo ou senso de compulsão para consumir a substancia;

Dificuldade de controlar o comportamento de consumir a substância em termos de início, término ou níveis de consumo;

$\square$ Um estado de abstinência fisiológico, quando o uso da substância cessou ou foi reduzido;

- Evidência de tolerância;

- Abandono progressivo de prazeres ou interesses alternativos em favor do uso da substância, aumento da quantidade do tempo necessário para obter ou tomar a substancia ou para se recuperar dos seus efeitos;

- Persistência do uso da substancia, a despeito de evidências claras de consequências manifestadamente nocivas. 


\section{Anexo E (Protocolo comum do GREA, adaptado)}

\section{GRUPO INTERDISCIPLINAR DE ESTUDO DE ÁLCOOL E DROGAS DO INSTITUTO DE PSIQUIATRIA DO HOSPITAL DAS CLÍNICAS DA FACULDADE DE MEDICINA DA UNIVERSIDADE DE SÃO PAULO}

Sobrenome, nome:

\begin{tabular}{|c|c|}
\hline $\begin{array}{l}\text { 02. Sexo } \\
1 \text { - masculino } \\
2-\text { feminino }\end{array}$ & $\begin{array}{l}\text { 03. Cor } \\
1 \text { - branca } \\
2 \text { - preta } \\
3 \text { - parda } \\
4 \text { - amarela } \\
5 \text { - outra }\end{array}$ \\
\hline
\end{tabular}

06. Situação Profissional

1 - empregado com registro

2 - empregado sem registro

3 - "bicos"

4 - desempregado

5 - aposentado por álcool

6 - aposentado por doença

7 - aposentado por tempo de serviço

14 - aposentado por idade

10 - "caixa" por álcool

11 - "caixa" por doença

12 - autônomo

13 - dona-de-casa

98 - não disponível

08. Grau de Instrução

1 - analfabeto

2 - primário incompleto

3 - primário completo

4 - ginásio incompleto

5 - ginásio completo

6 - segundo grau incompleto

7 - segundo grau completo

8 - superior incompleto

9 - superior completo
04. Idade
05. Estado Civil
1 - casado
2 - solteiro
3 - viúvo
4 - separado
5 - amasiado

\section{Salário Mensal}

OBS: Verter a quantia citada em número de salários mínimos

10. Nome do entrevistador:

09. Local de Nascimento

1 - São Paulo - Capital

2 - São Paulo - Interior

3 - Sul

4 - outros estados do Sudeste

5 - Nordeste - Norte

6 - outros estados

- outros países 


\section{INFORMAÇÕES SOBRE O USO DO ÁLCOOL}

11. Idade de Início de Ingestão )anos
12. Idade de Aumento )anos
13. Idade de Início de Problema (__ anos

(Físico, Psíquico ou Social)
14. Tipo de Bebida

01 - pinga

02 - cerveja

04 - vinho

08 - uísque

32 - conhaque

64 - vodca

16 - outros

OBS: No caso de o paciente fazer uso de mais de uma bebida, cada uma delas deve ser somada.

Ex: cerveja $(02)+$ vinho $(04)=06$

16. Tratamento anterior para alcoolismo Número de Internações

001 - ambulatorial

002 - internação psiquiátrica

004 - internação clínica

008 - A.A.

016 - psicoterapia

032 - antabuse

064 - religioso

128 - alternativos

256 - GREA Entrada (ano)

Alta

(ano)

998 - Sem tratamento prévio

OBS: no caso de haver mais de um tipo de tratamento, devem ser somados.

Ex: ambulatorial $(001)+$ A.A. $(008)=009$

18. Uso de drogas

001 - nunca

002 - não injetável

004 - injetável, não no momento

016 - injetável, em uso
15. Quantidade de Etanol

No Momento da Consulta (gramas/dia)

OBS: Quantidade = volume $\mathrm{x}$ densidade do álcool (0.8) $\times$ percentagem de álcool na bebida. 1 dose $=$ $50 \mathrm{ml}$.

Levar em consideração a pior semana do último mês

Percentagem de álcool:

- cerveja: $3 \%$

- vinho: $12 \%$

- conhaque : $40 \%$

- pinga, vodca, uísque: $50 \%$

17. Familiares com Problemas com Álcool

001 - pai

002 - mãe

004 - filho

008 - irmão

064 - avós paternos

128 - avós maternos

256 - tios paternos

512 - tios maternos

1024 - primos paternos

2048 - primos maternos

4096 - marido

8192 - outros

998 - Não têm antecedentes familiares

OBS: no caso de haver mais de um familiar devem ser somados

19. Tipo de Droga

001 - cannabis

002 - cocaína

004 - barbitúricos

008 - anfetaminas

016 - opióides

032 - benzodiazepínicos

064 - outras

998 - não faz uso de droga.

064 discriminar:

OBS: No caso de haver mais de um tipo de droga, devem ser somadas 
20. Idade de Início de Consumo

21. Idade de Aumento

23. Tratamento Anterior para Farmacodependências Número de internações

001 - ambulatorial

002 - internação psiquiátrica

004 - internação clínica

008 - psicoterapia

032 - antabuse

064 - religioso

128 - alternativos

256 - GREA Entrada (ano)
Alta (ano)

998 - sem tratamento prévio

OBS: no caso de haver mais de um tipo de tratamento, devem ser somados.
22. Idade de Início de Problema com

Drogas | (Físico, Psíquico ou Social)
24. Familiares com problemas com drogas

001 - pai

002 - mãe

004 - filho

008 - irmão

064 - avós paternos

128 - avós maternos

256 - tios paternos

512 - tios maternos

1024 - primos paternos

2048 - primos maternos

4096 - marido

8192 - outros

998 - não tem antecedentes familiares

OBS: no caso de haver mais de um familiar devem ser somados

\section{INFORMAÇÕES SOBRE O USO DE DROGAS INFORMAÇÕES GERAIS}

25. Uso de Seringas e Materiais contaminados

01 - sempre

02 - nunca

03 - às vezes

04 - sem, há mais de 5 anos

98 - não se encaixa

27. Tentativa de Suicídio

01 - não

02 - sim, quando alcoolizado

03 - sim, não alcoolizado

04 - sim, intoxicado por outras drogas

05 - sim, não intoxicado por drogas

34. Tipo de Instrumento

ESA - Álcool

37. Data de Início do Tratamento
26. Grupo de Risco para AIDS:

01 - homossexualidade

02 - transfusão

08 - uso de drogas injetáveis

16 - contactante sexual de um dos grupos acima

32 - promiscuidade

98 - não se enquadra

OBS: no caso de haver mais de um, devem ser somados.

28. A iniciativa para buscar tratamento partiu:

01-do paciente

02 - do companheiro

03 - dos filhos

04 - dos pais

05 - encaminhamento médico

06 - encaminhamento da empresa

07 - parentes

08 - amigos

35. Nome do avaliador

36. Notas da ESA

38. Data desta Avaliação 


\section{Anexo F (SADD)}

\section{Short-Form Alcohol Dependence Data - SADD (Raistrick, 1983)}

1. Você acha difícil tirar o pensamento de beber da cabeça?

2. Acontece de você deixar de comer por causa de bebida?

Nunca $\begin{gathered}\text { Poucas } \\ \text { vezes }\end{gathered} \begin{gathered}\text { Muitas } \\ \text { vezes }\end{gathered}$ Sempre

3. Você planeja seu dia em função da bebida?

() ( ) ( ) ( )

4. Você bebe em qualquer horário (manhã, tarde e/ou noite)?

( ) ( ) ( ) ( )

() $\quad() \quad() \quad()$

() $\quad() \quad() \quad()$

5. Na falta de sua bebida preferida você toma qualquer outra?

( ) ( ) ( ) ( )

6. Acontece de você beber sem levar em conta os compromissos que tenha depois?

( ) ( ) ( ) ( )

7. Você acha que o quanto você bebe chega a the prejudicar?

( ) ( ) ( ) ( )

8. No momento em que você começa a beber, é difícil parar?

() () () ()

9. Você tenta se controlar (tenta deixar de beber)?

10. Na manhã seguinte a uma noite em que tenha bebido muito, você precisa beber para se sentir melhor?

( ) ( ) ( ) ( )

() $\quad\left(\begin{array}{lll}) & () \quad()\end{array}\right.$

11. Você acorda com tremores nas mãos na manhã seguinte a uma noite em que tenha bebido muito?

( ) ( ) ( ) ( )

12. Depois de ter bebido muito, você levanta com náuseas ou vômitos?

$\begin{array}{llll}() & () & () & ()\end{array}$

13. Na manhã seguinte a uma noite em que tenha bebido muito,

você levanta não querendo ver ninguém na sua frente?

() $\quad() \quad() \quad()$

14. Depois de ter bebido muito, você vê coisas que mais tarde percebe que eram imaginação sua?

( ) $\quad\left(\begin{array}{lll}) & () \quad()\end{array}\right.$

15. Você se esquece do que aconteceu enquanto esteve bebendo?

( ) ( ) ( )




\section{Anexo G (AUDIT)}

\section{Alcohol Use Disorders Identification Test - AUDIT (Babor et al., 1992b)}

1 Com que frequência você consome bebidas alcoólicas (cerveja, vinho, cachaça, etc.)?
(0) Nunca
(1) Uma vez por mês ou menos
(2) 2 a 4 vezes por mês
(3) 2 a 3 vezes por semana
(4) 4 ou mais vezes por semana

3. Com que freqüência que você consome 6 ou mais doses de bebida alcoólica em uma única ocasião?
(0) Nunca
(1) Menos que mensalmente
(2) Mensalmente
(3) Semanalmente
(4) Diariamente ou quase diariamente

5. Com que freqüência, durante os últimos doze meses, você deixou de fazer algo ou atender a um compromisso devido ao uso de bebidas alcoólicas?
(0) Nunca
(1) Menos que mensalmente
(2) Mensalmente
(3) Semanalmente
(4) Diariamente ou quase diariamente

7. Com que freqüência você sentiu-se culpado ou com remorso depois de beber?
(0) Nunca
(1) Menos que mensalmente
(2) Mensalmente
(3) Semanalmente
(4) Diariamente ou quase diariamente

9. Você ou outra pessoa já se machucou devido a alguma bebedeira sua?
(0) Nunca
(2) Sim, mas não nosúltimos 12 meses
(4) Sim, nos últimos 12 meses

Data:

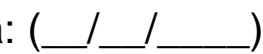

2. Quantas doses, contendo álcool, você consome num dia em que normalmente bebe.
(1) 1 a 2
(2) 3 a 4
(3) 5 a 6
(4) 7 a 9
(5) 10 ou mais

4. Com que freqüência, durante os últimos doze meses, você percebeu que não conseguia parar de beber uma vez que havia começado?
(0) Nunca
(1) Menos que mensalmente
(2) Mensalmente
(3) Semanalmente
(4) Diariamente ou quase diariamente

6. Com que freqüência, durante os últimos doze meses, você precisou de uma primeira dose pela manhã para sentir-se melhor depois de uma bebedeira?
(0) Nunca
(1) Menos que mensalmente
(2) Mensalmente
(3) Semanalmente
(4) Diariamente ou quase diariamente

8. Com que freqüência, durante os últimos doze meses, você não conseguiu lembrar-se do que aconteceu na noite anterior porque havia bebido?
(0) Nunca
(1) Menos que mensalmente
(2) Mensalmente
(3) Semanalmente
(4) Diariamente ou quase diariamente

10. Algum parente, amigo, médico ou outro profissional de saúde mostrou-se preocupado com seu modo de beber ou sugeriu que você diminuísse a quantidade?

(0) Nunca

(2) Sim, mas não nos últimos 12 meses

(4) Sim, nos últimos 12 meses

Pontuação 


\section{Anexo H (CIWA-Ar)}

\section{Clinical Institute Withdrawal Assessment for Alcohol Revised, CIWA-Ar (Sullivan et al., 1989)}

Nome:

Data:

Pulso ou FC:

1. Você sente um mal estar no estômago (enjoo)? Você tem vomitado?

0 - Não

1 - Náusea leve e sem vômito

4 - Náusea recorrente com ânsia de vômito

7 - Náusea constante, ânsia de vômito e vômito

3. Sudorese:

0 - Não

4 - Facial

7 - Profusa

5. Você tem ouvido sons a sua volta? Algo perturbador, sem detectar nada por perto?

$$
\begin{array}{ll}
0 \text { - Não } & 4 \text { - Moderado / grave } \\
\text { 1- Muito leve } & 5-\text { Grave } \\
\text { 2- Leve } & 6 \text { - Muito grave } \\
\text { 3-Moderado } & 7 \text { - Extremamanete grave }
\end{array}
$$

7. Você se sente nervoso (a)? (observação)

0 - Não

1 - Muito leve

4 - Leve

7 - Ansiedade grave, estado de pânico, semelhante a um estado psicótico agudo.

9. Agitação (Observação):

0 - Normal

1 - Um pouco mais que a atividade normal

4 - Moderadamente

7 - Constante
PA:

Hora:

2. Tremor com os braços estendidos e os dedos separados:

0 - Não

1 - Não visível, mais sente

4 - Moderado, com os braços estendidos

7 - Severo, mesmo com os braços estendidos

4. Tem sentido coceiras, sensação de insetos andando no corpo, formigamentos, pinicações?

$$
\begin{array}{ll}
0 \text { - Não } & 4 \text { - Moderado / grave } \\
\text { 1- Muito leve } & 5 \text { - Grave } \\
2 \text { - Leve } & 6 \text { - Muito grave } \\
3 \text { - Moderado } & 7 \text { - Extremamanete grave }
\end{array}
$$

6. As luzes têm parecido muito brilhantes? De cores diferentes? Incomodam os olhos? Você tem visto algo que tem Ihe perturbado? Você tem visto coisas que não estão presentes?

$$
\begin{array}{ll}
0 \text { - Não } & \text { 4-Alucinações moderadas } \\
\text { 1- Muito leve } & 5 \text { - Alucinações graves } \\
\text { 2- Leve } & \text { 6-Extremamente graves } \\
\text { 3-Moderado } & 7 \text { - Continua }
\end{array}
$$

8. Você sente algo na cabeça? Tontura, dor, apagamento?

$$
\begin{array}{ll}
0 \text { - Não } & 4 \text { - Moderado / grave } \\
\text { 1- Muito leve } & 5 \text { - Grave } \\
\text { 2- Leve } & 6 \text { - Muito grave } \\
\text { 3-Moderado } & 7 \text { - Extremamanete grave }
\end{array}
$$

10. Que dia é hoje? Onde você está? Quem sou eu? (observação)

0 - Orientado

1 - Inserto sobre data, não responde seguramente

2 - Desorientado sobre data, não mais que dois dias

3 - Desorientado com a data, com mais de 2 dias.

4 - Desorientado com lugar e pessoa.

Escore 
Anexo I (Escala de seguimento de alcoolistas)

ESA - Escala de seguimento de alcoolistas (Andrade, 1991)

\begin{tabular}{|c|c|c|c|c|c|}
\hline & Consumo alcoólico & Ocupação & Relações familiares & Lazer & Comp. org. \\
\hline $\begin{array}{l}\mathrm{N} \\
\mathrm{O} \\
\mathrm{T} \\
\mathrm{A}\end{array}$ & $\begin{array}{l}\text { "Como está o seu consumo } \\
\text { alcoólico"? (últimas } 4 \\
\text { semanas) }\end{array}$ & $\begin{array}{l}\text { "Em relação ao trabalho, como o } \\
\text { Sr. está?" (últimas } 4 \text { semanas) }\end{array}$ & $\begin{array}{l}\text { "Com quem o Sr. } \\
\text { mora?" (últimas } 4 \\
\text { semanas) }\end{array}$ & $\begin{array}{l}\text { "Como o Sr. ocupa o } \\
\text { seu tempo livre?" } \\
\text { (últimas } 4 \text { semanas) }\end{array}$ & $\begin{array}{l}\text { Nível sérico } \\
\text { GAMA_GT }\end{array}$ \\
\hline 1 & $\begin{array}{l}\text { Bebendo "direto", com vários } \\
\text { episódios de embriaguez } \\
\text { vem embriagado à consulta }\end{array}$ & $\begin{array}{l}\text { Não trabalha, abandonou suas } \\
\text { atividades, ou perdeu o emprego }\end{array}$ & Não tem onde morar & $\begin{array}{l}\text { O passatempo } \\
\text { principal é a bebida }\end{array}$ & $\begin{array}{l}\text { Acima de } 300 \\
\text { UI/L }\end{array}$ \\
\hline 2 & $\begin{array}{l}\text { Bebendo diariamente, com } \\
\text { poucos episódios de } \\
\text { embriaguez }\end{array}$ & $\begin{array}{l}\text { Atividades e/ou sustento } \\
\text { passaram para a } \\
\text { responsabilidade de outra } \\
\text { pessoa }\end{array}$ & $\begin{array}{l}\text { Mora com familiares } \\
\text { em situação de } \\
\text { isolamento }\end{array}$ & $\begin{array}{l}\text { Atividade de lazer, } \\
\text { somente, quando } \\
\text { estimulada }\end{array}$ & $\begin{array}{l}\text { De } 101 \text { a } 300 \\
\text { UI/L }\end{array}$ \\
\hline 3 & $\begin{array}{l}\text { Bebendo várias vezes na } \\
\text { semana }\end{array}$ & Atividade irregular & $\begin{array}{l}\text { Mora com familiares, } \\
\text { com agressões } \\
\text { físicas }\end{array}$ & Atividades de rotina & $\begin{array}{l}\text { De } 71 \text { a } 100 \\
\text { UI/L }\end{array}$ \\
\hline 4 & Bebedor moderado (ocasional) & $\begin{array}{l}\text { Atividades regulares, mas com } \\
\text { dificuldade na realização das } \\
\text { tarefas }\end{array}$ & $\begin{array}{l}\text { Mora com familiares, } \\
\text { com agressões } \\
\text { verbais }\end{array}$ & $\begin{array}{l}\text { Atividade, gratificante, } \\
\text { esporádica }\end{array}$ & De 29 a $70 \mathrm{UI} / \mathrm{L}$ \\
\hline 5 & Abstinência & Trabalho estável & $\begin{array}{l}\text { Situação familiar } \\
\text { estável }\end{array}$ & $\begin{array}{l}\text { Atividade, gratificante, } \\
\text { regularmente }\end{array}$ & $\begin{array}{l}\text { Até } 28 \mathrm{UI} / \mathrm{L} \\
\text { (normal) }\end{array}$ \\
\hline
\end{tabular}


Anexo $\mathbf{J}$ (Hamilton - 21 itens)

\section{Escala de depressão Hamilton - 21 (Hamilton, 1960)}

1. HUMOR DEPRIMIDO (Tristeza, desesperança, desamparo, inutilidade)

(0) Ausente.

(1) Sentimentos relatados apenas ao ser inquirido.

(2) Sentimentos relatados espontaneamente com palavras.

(3) Comunica os sentimentos não com palavras, isto é, com a expressão facial, a postura, a voz e a tendência ao choro.

(4) Sentimentos deduzidos da comunicação verbal e não-verbal do paciente.

\section{SUICÍDIO}

(0) Ausente.

(1) Sente que a vida não vale a pena.

(2) Desejaria estar morto ou pensa na probabilidade de sua própria morte.

(3) Idéias ou gestos suicidas.

(4) Tentativa de suicídio ( qualquer tentativa séria, marcar 4).

\section{INSÔNIA INTERMEDIÁRIA}

(0) Sem dificuldades.

(1) O paciente se queixa de inquietude e perturbação durante a noite.

(2) Acorda à noite - qualquer saída da cama marcar 2 ( exceto $\mathrm{p} /$ urinar).

\section{TRABALHO E ATIVIDADES}

(0) Sem dificuldades.

(1) Pensamento e sentimentos de incapacidade, fadiga ou fraqueza relacionada a atividades, trabalho ou passatempos.

(2) Perda de interesse por atividades (passatempos ou trabalho) quer diretamente relatada pelo paciente, quer indiretamente por desatenção, indecisão e vacilação (sente que precisa esforçar-se para o trabalho ou atividade).

(3) Diminuição do tempo gasto em atividades ou queda de produtividade. No hospital, marcar 3 se o paciente não passar ao menos 3 horas por dia em atividades externas (trabalho hospitalar ou passatempo).

(4) Parou de trabalhar devido à doença atual. No hospital, marcar 4 se o paciente não se ocupar com outras atividades, além de pequenas tarefas do leito, ou for incapaz de realizá-las sem ajuda.

\section{SENTIMENTOS DE CULPA}

(0) Ausente

(1) Auto-recriminação; sente que decepcionou os outros.

(2) Idéias de culpa ou ruminação sobre erros passados ou más ações.

(3) A doença atual é um castigo.

(4) Ouve vozes de acusação ou denúncia e/ou tem alucinações visuais ameaçadoras.

\section{INSÔNIA INICIAL}

(0) Sem dificuldades para conciliar o sono.

(1) Queixa-se de dificuldade ocasional para conciliar o sono, isto é, mais de meia hora.

(2) Queixa-se de dificuldade para conciliar o sono todas as noites.

\section{INSÔNIA TARDIA}

(0) Sem dificuldades.

(1) Acorda de madrugada, mas volta a dormir

(2) Incapaz de voltar a conciliar o sono se deixar a cama.

8. RETARDO (lentidão de idéias e fala; dificuldade de concentração; atividade motora diminuída)

(0) Pensamento e fala normais.

(1) Leve retardo à entrevista.

(2) Retardo óbvio à entrevista.

(3) Entrevista difícil.

(4) Estupor completo.

\section{AGITAÇÃO}

(0) Nenhuma.

(1) Inquietude.

(2) Brinca com as mãos, com os cabelos,etc.

(3) Mexe-se, não consegue sentar quieto.

(4) Torce as mãos, rói as unhas, puxa os cabelos, morde os lábios. 


\section{ANSIEDADE PSÍQUICA}

(0) Sem dificuldade

(1) Tensão e irritabilidade subjetivas.

(2) Preocupação com trivialidades.

(3) Atitude apreensiva aparente no rosto ou na fala.

(4) Medos expressos sem serem inquiridos.

\section{SINTOMAS SOMÁTICOS GASTRINTESTINAIS}

(0) Nenhum

(1) Perda de apetite, mas alimenta-se voluntariamente. Sensações de peso no abdomen

(2) Dificuldade de comer se não insistirem. Solicita ou exige laxativos ou medicações para os intestinos ou para sintomas digestivos.

14. SINTOMAS GENITAIS Sintomas como: perda da libido, distúrbios menstruais
(0) Ausentes
(1) Leves
(2) Intensos

\section{PERDA DE PESO (Marcar A ou B)}

A - Quando avaliada pela história clínica

(0) Sem perda de peso.

(1) Provável perda de peso associada à moléstia atual.

(2) Perda de peso definida ( de acordo com o paciente)

(3) Não avaliada.

B - Avaliada semanalmente pelo psiquiatra responsável, quando são medidas alterações reais de peso

(0) Menos de 0,5 Kg de perda por semana.

(1) Mais de $0,5 \mathrm{Kg}$ de perda por semana.

(2) Mais de $1 \mathrm{Kg}$ de perda por semana.

(3) Não avaliada.

\section{VARIAÇÃO DIURNA}

A - Observar se os sintomas são piores pela manhã ou à tarde. Caso NÃO haja variação, marcar "nenhuma".

(0) Nenhuma

(1) Pior de manhã.

(2) Pior à tarde.
11. ANSIEDADE SOMÁTICA

Concomitantes fisiológicos de ansiedade, tais como: Gastrointestinais: boca seca, flatulência, indisgestão, diarréia, cólicas, eructação; Cardiovasculares: palpitações, cefaléia; Respiratórios: hiperventilação, suspiros; Freqüência urinária; Sudorese
(0) Ausente :
(1) Leve
(2) Moderada
(3) Grave
(4) Incapacitante

\section{SINTOMAS SOMÁTICOS EM GERAL}

(0) Nenhum

(1) Peso nos membros, nas costas ou na cabeça. Dores nas costas, cefaléia, mialgias.

Perda de energia e cansaço.

(2) Qualquer sintoma bem caracterizado e nítido, marcar 2.

\section{HIPOCONDRIA}

(0) Ausente

(1) Auto-observação aumentada (com relação ao corpo)

(2) Preocupação com a saúde

(3) Queixas freqüentes, pedidos de ajuda,etc.

(4) Idéias delirantes hipocondríacas.

\section{CONSCIÊNCIA}

(0) Reconhece que está deprimido e doente.

(1) Reconhece a doença mas atribui-Ihe a causa à má alimentação, ao clima, ao excesso de trabalho, a vírus, à necessidade de repouso, etc.

(2) Nega estar doente.
18.

B - Quando presente, marcar a gravidade da variação. Marcar "nenhuma" caso NÃO haja variação.

(0) Nenhuma.

(1) Leve

(2) Grave

NOTA: Caso haja variação diurna, só a contagem referente à sua gravidade (1 ou 2 pontos no ítem 18B) é que deve ser incluída na contagem final. O ítem $18 \mathrm{~A}$ não deve ser computado. 
19. DESPERSONALIZAÇÃO E PERDA DE NOÇÃO DE REALIDADE. Tais como: sensações de irrealidade, idéias niilistas
(0) Ausente
(1) Leve.
(2) Moderadas.
(3) Graves.
(4) Incapacitantes.

21. SINTOMAS OBSESSIVOS E COMPULSIVOS

(0) Nenhum.

(1) Leves.

(2) Graves.
20. SINTOMAS PARANÓIDES
(0) Nenhum
(1) Desconfiança.
(2) Idéias de referência.
(3) Delírio de referência e perseguição.
SOMAR OS PONTOS OBTIDOS EM TODOS OS ÍTENS
(EXCETO $18 \mathrm{~A})$

CONTAGEM TOTAL: (0-62) 


\section{Anexo K (OCDS)}

\section{Obsessive Compulsive Drinking Scale - OCDS (Anton et al., 1996)}

1. Quanto do seu tempo é ocupado por ideias, pensamentos, impulsos e imagens relacionados ao uso de álcool, quando você não está bebendo?
(1) Nenhum
(2) Menos de uma hora por dia
(3) 1 a 3 horas por dia
(4) 4 a 8 horas por dia
(5) Mais de 8 horas por dia

2. Com que frequência esses pensamentos ocorrem?

(1) Nunca

(2) Não mais de 8 vezes por dia

(3) Mais de 8 vezes por dia, mas na maior parte do dia os pensamentos não ocorrem.

(4) Mais de 8 vezes por dia e durante a maior parte do dia.

(5) Os pensamentos são tão numerosos, que raramente passa uma hora sem ocorrerem.

3. Quanto destas ideias, pensamentos, impulsos ou imagens relacionadas ao uso de álcool interferem com suas atividades (ou papel) sociais ou profissionais? Existe algo que você não faz ou não pode fazer por causa deles? (Se você não está trabalhando atualmente, quanto de seu rendimento seria afetado caso estivesse trabalhando?).

(1) Os pensamentos de beber nunca interferem - Eu posso funcionar normalmente.

(2) Os pensamentos de beber interferem levemente com minhas atividades sociais e profissionais, mas meu rendimento global não está prejudicado.

(3) Os pensamentos de beber definitivamente interferem com minhas atividades sociais ou profissionais, mas eu ainda posso controlá-los.

(4) Os pensamentos de beber causam importante prejuízo em minhas atividades sociais e profissionais.

(5) Os pensamentos de beber interferem completamente com minhas atividades sociais ou profissionais.

As questões abaixo perguntarão sobre o seu consumo de álcool e suas tentativas para controlálo. Por favor, circule a alternativa que se aplica a você:

4. Quanto de ansiedade ou prejuízo estas ideias, pensamentos, impulsos e imagens relacionados ao uso de álcool lhe causam, quando não está bebendo?

(1) Nenhum.

(2) Leve, infrequente e não tão incapacitante.

(3) Moderado, frequente e incapacitante, mas ainda controláveis.

(4) Grave, muito frequente e muito incapacitante.

(5) Extremo, constante e angustiante.

6. Você consegue parar ou controlar estes pensamentos?

(1) Eu consigo totalmente;

(2) Eu, comumente, consigo;

(3) Eu, às vezes, consigo;

(4) Eu, raramente, consigo;

(5) Eu não consigo
5. Quanto esforço você precisa fazer para resistir, ignorar ou desviar a sua atenção dos pensamentos de beber, quando eles entram em sua mente, quando não está bebendo? (Por favor, avalie somente o seu esforço para resistir aos pensamentos, mas não seu sucesso ou incapacidade para controlá-los atualmente).

(1) Meus sintomas são tão mínimos, que não preciso resistir ativamente. Se eu tenho pensamentos, eu faço sempre um esforço para resistir.

(2) Eu tento resistir a maior parte do tempo.

(3) Eu faço algum esforço para resistir.

(4) Eu cedo com relutância aos pensamentos de beber sem tentar controlá-los.

(5) Eu cedo completamente e espontaneamente aos pensamentos de beber.

7. Quantas doses você bebe por dia?
(1) Nenhum.
(2) Menos de uma dose por dia.
(3) 1 a 2 doses por dia.
(4) 3 a 7 doses por dia.
(5) 8 ou mais doses por dia. 
8. Quantos dias por semana você bebe?
(1) Nenhum.
(2) Não mais de 1 dia por semana.
(3) 2 a 3 dias por semana.
(4) 5 dias por semana.
(5) 7 dias por semana.

10. A quantidade de álcool, que você bebe interfere com suas atividades sociais? Existe algo que você não faz ou não pode fazer por causa do consumo de álcool?

(1) O consumo de álcool nunca interfere - Eu funciono normalmente.

(2) O consumo de álcool interfere levemente com minhas atividades sociais, mas o meu rendimento global não está afetado.

(3) O consumo de álcool interfere definitivamente com minhas atividades sociais, mas ainda posso controlá-lo.

(4) O consumo de álcool causa prejuízo importante em minhas atividades sociais.

(5) Problemas com o consumo de álcool interferem completamente com minhas atividades sociais.

12. Quanto esforço você faz para resistir do desejo de beber? (avalia apenas o esforço em resistir ao desejo de beber, mas não seu sucesso ou incapacidade para controlá-los atualmente).

(1) Meu consumo é tão raro, que não necessito resistir.

(2) Resisto a maior parte do tempo.

(3) Faço algum esforço para resistir.

(4) Cedo com relutância ao desejo de beber.

(5) Eu cedo completamente ao desejo de beber.

13. Quanto forte é o desejo para consumir bebidas alcoólicas?

(1) Nenhum desejo.

(2) Alguma pressão social para beber.

(3) Pressão forte para beber.

(4) Pressão muito forte para beber.

(5) Desejo para beber é completamente involuntário e sufocante.
9. A quantidade de álcool, que você bebe interfere com suas atividades profissionais? Existe algo que você não faz ou não pode fazer por causa do consumo de álcool? (Se você não está trabalhando atualmente, quanto de seu rendimento seria afetado caso estivesse trabalhando?).

(1) O consumo de álcool nunca interfere - Eu funciono normalmente.

(2) O consumo de álcool interfere levemente com minhas atividades profissionais, mas o meu rendimento global não está afetado.

(3) O consumo de álcool interfere definitivamente com minhas atividades profissionais, mas ainda posso controlálo.

(4) O consumo de álcool causa prejuízo importante em minhas atividades profissionais.

(5) Problemas com o consumo de álcool interferem completamente com minhas atividades profissionais.

11. Se você estivesse impedido de consumir álcool, quanto ansioso e irritado você ficaria ao desejar beber?

(1) Não experimentaria nenhuma ansiedade e irritabilidade.

(2) Eu ficaria levemente ansioso e irritado

(3) A ansiedade e irritabilidade aumentariam, mas permaneceria controlável.

(4) Eu experimentaria um aumento importante da ansiedade e irritabilidade.

(5) Eu experimentaria uma ansiedade e irritabilidade incapacitante.

14. Quanto controle você tem sobre o consumo de álcool?

(1) Eu tenho um controle completo.

(2) Eu geralmente sou capaz de exercer controle voluntário sobre o consumo de álcool.

(3) Eu posso controlá-lo somente com dificuldade.

(4) Eu tenho que beber e somente posso evitar o consumo de álcool com dificuldade.

(5) Eu raramente sou capaz de evitar o consumo de álcool mesmo momentaneamente

\section{Pontuação Total:}


Anexo L (UKU)

Ugvald for Kliniske Undersgelser - UKU (Lingjaerde, 1987)

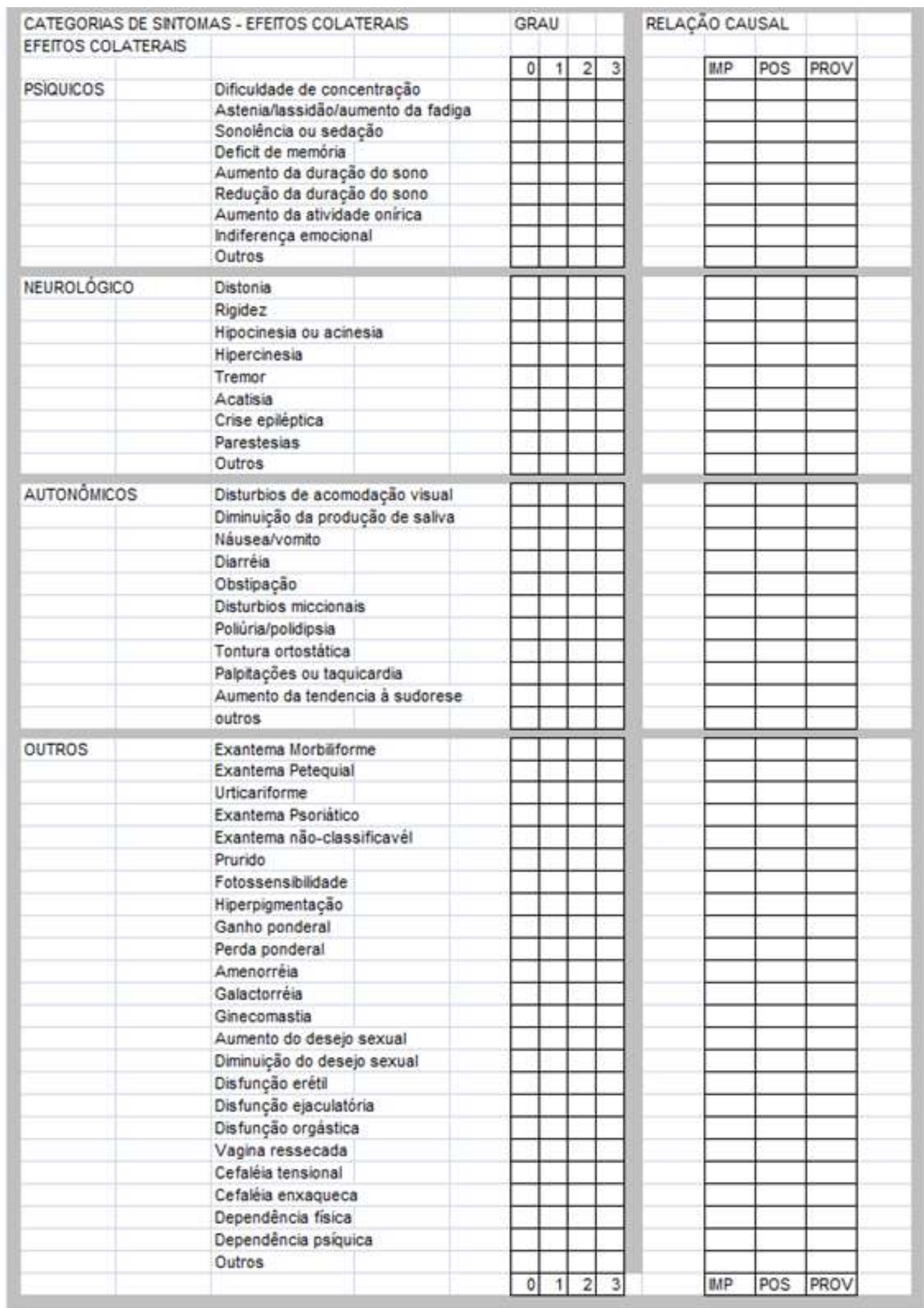


Anexo M (Artigo publicado na European Addiction Research)

Research Report

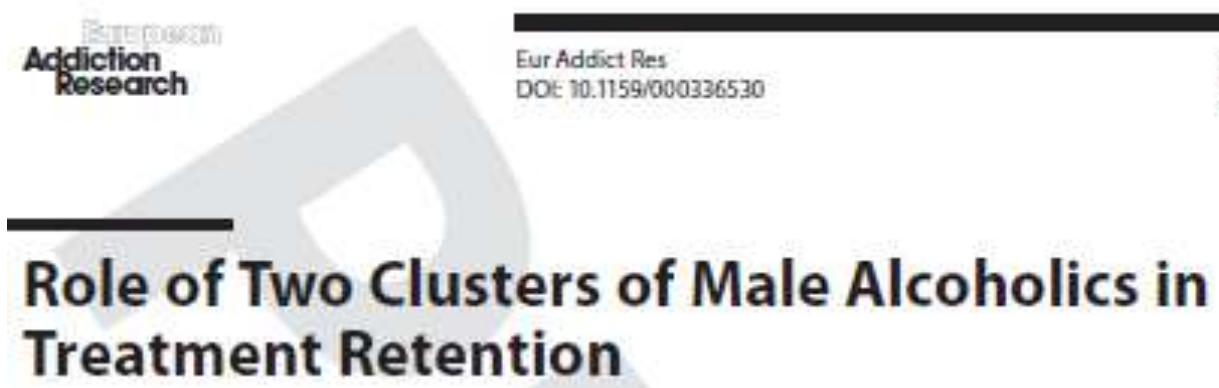

\author{
Danilo Antonio Baltieri, b João Maria Correa Filho ${ }^{a}$ \\ "Department of Psychiatry of the University of Ssa Paula, and 'Department of Psychiatry of ABC Medical School- \\ Santo André, Sáo Paulo, Brazil
}

Boctivod: Novernber 15,2011 Accuptod Jamuary 70 , 2012 Publishod orline:as:

\section{Key Words}

Pharmacological trials - Cluster analysis - Alcoholics Anonymous groups - Psychosocial interventions

\section{Abstract}

Alms: This study aimed to dassify alcohol-dependent outpatients on the basis of clinical factors and to verify if the resulting types show different treatment retention. Methods: The sample comprised 332 alcoholics that were enrolled in three different pharmacological trials carried out at Sáo Paulo University, Brazil. Based on four clinical factors problem drinking onset age, familial alcoholism, alcohol dependence severity, and depression - K-means cluster analysis was performed by using the average silhouette width to determine the number of clusters. A direct logistic regression was performed to analyze the influence of clusters, medication groups, and Akcoholics Anonymous (AA) attendance in treatment retention. Results: Two clusters were delineated. The cluster characterized by earlier onset age, more familial alcoholism, higher alcoholism severity, and less depression symptoms showed a higher chance of discontinuing the treatment, independently of medications used and AA attendance. Participation in AA was significantly related to treatment retention. Dfscussion: Health services should broaden the scope of services offered to meet heterogeneous needs of clients, and identify treatment practices and therapists which improve retention. Information about patients' characteristics linked to dropout should be used to make treatment programs more responsive and attractive, combining pharmacological agents with more intensive and diversified psychosocial interventions.

Copprignte 2012 S. Kargar AG, Basel

\section{Introduction}

Alcoholics are a highly heterogeneous population. Their categorization into more homogeneous groups has received great attention from mental health professionals worldwide. An appropriate system of classification can represent a broad understanding of underlying neurobiological and psychosocial aspects of this disease, as well as being related to a therapeutic proposal, a possible prognosis and different forms of approach.

Substantial numbers of alcohol dependents leave treatment before completing the program and this contributes to negative consequences to their health, families, finances, and job performance. Several authors have affirmed that client-centered characteristics display some role in treatment retention [1]. Given the heterogeneity of alcoholics, it is possible that specific types of alcoholics show higher compliance with specific treatment models.

\begin{tabular}{|c|c|}
\hline KARGER & 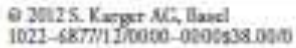 \\
\hline 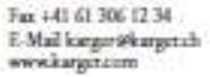 & 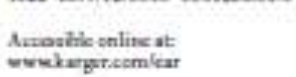 \\
\hline
\end{tabular}

\author{
Prol. Dr. Damila Ansanis Haliveri

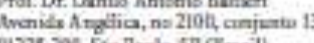

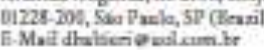


A range of studies have shown that longer durations of treatment and treatment completion are associated with better outcomes in alcohol programs [2]. In the same way. better outcomes generally occur with improved treatment retention. This justifies substantial efforts to verify for whom certain treatment models can be more effective and attractive.

Various studies have investigated different therapeutic options in respect to some typologies of alcoholics [3]. For example, Cloninger [4] proposed that people with early onset of alcohol problems differ clinically from people with later onset. The group of early-onset alcoholics (EOA) commonly presents an earlier history of problem drinking, a wider range of antisocial behaviors, a higher level of alcohol craving, and more frequent family disease history among first-degree relatives than the group of late-onset alcoholics (L.OA) $[5,6]$. Given the different serotonergic abnormalities between both groups, ondansetron has shown be particularly effective in EOA while antidepressants seem to be more efficacious in LOA [7] Also, given that naltrexone has been shown to be effective for patients with high levels of alcohol craving and a substantial family history of alcoholism, EOA could benefit most from this medication $[8,9]$. On the other hand, there does not seem to be a reliable association between problem drinking onset age and acamprosate effectiveness [10]. Lesch and Walter [11] developed a typology that describes four types of alcoholics by integrating biological, social, and psychological factors. Kiefer et al. [12] used Lesch's typology and found that acamprosate was more effective in type 1 patients while naltrexone was more efficacious in type 3 and 4 patients. Also, the Austrian Acamprosate Trial results showed a better response to acamprosate in type 1 and 2 patients [13]. Conversely, the United Kingdom Multicentre Acamprosate Study did not show any differences in response to acamprosate regarding Lesch's typology [14]. Babor et al. [15] created a typology that describes two types of alcoholics - A and B. Whilst type $A$ is characterized by a late onset of problem drinking, low severity of dependence, little drug use, and a relatively better prognosis with traditional treatment, type $B$ is characterized by an earlier onset of problem drinking, high severity of dependence, polydrug use, a high degree of concomitant psychopathology, and a poor prognosis with alcoholism treatment. Other authors have demonstrated that type $\mathrm{A}$ alcoholics show better drinking outcomes with antidepressants than their counterparts $[16,17]$. On the other hand, the antipsychotic quetiapine seems to perform a better role for type B alcoholics than for type A [18].
Based upon these findings, we combined three databases and performed a $K$-means cluster analysis to identify types of alcoholics and evaluate if these types show different retention rates in different standardized pharmacological treatments. We are aware that treatment retention is not a proper outcome measure, however the capacity to retain patients in active participation is a sensible measurement associated with quality and efficacy of healthcare [19, 20]. Also, according to the National Treatment Agency for Substance Misuse, retention in drug treatment is the better available measure of treatment effectiveness [21].

\section{Methods}

Datahases of three randomized, doable-blind, placebo-conirolled clinical trials were combined for this joint analysis. All of these trials were performed to detect the efficacy af active medications in reducing drinking, promoting abstinence and decreasing craving in alcobol-dependent outputients. The pharmacological treatments lasted 12 weeks.

We combined the datahases from the following double blind studies (a) a trial comparing acamprosate $(1,998 \mathrm{mg} / \mathrm{day})$ with placebo that was carried oat between 2001 and 2003 [22]. (b) a trial comparing topiramate (up to $300 \mathrm{mg} / \mathrm{day}$ ), naltrexane (50 mg/day) and placebo performed between 2004 and 2007 |23], and $(c)$ another ntudy comparing ondansetron (16 mg/day) with placebo developed between 2008 and 2010 (to be published) These trials were coordinated by the sme doctor and developed in the same dinical setting, following the same behavional ap proaches and double-blind principle. Figure 1 shows the flow chart of combined studies.

\section{Participunt:}

Male patients, $18-60$ years of age, with an International Clas sification of Diseases (ICD-10;-Warld Health Organizatinn, 1992) dizgnosix of aloobol dependence who enrolled as outputients in the Assistance Sector of the Interdisciplinary Group of Studies on Aloobol and Druggs at the Liniversity of Sao Paulo (GREA), were assessed for each trial This service (GREA) is exclusively dedicated to the treatment of males with alcoboland/or any other kind of drug abuse or dependence.

Exclusion criteria were similar for these clinical trials $(a)<18$ years or $>60$ years of age, (b) a current diagnosis of dependence or abuse of other subutances except nicotine; (c) patients with serious dinical coeristing diseases (e.g, inadequately controlled diabetes, candiac failure, alcoholic cirrhosias); (d) previous treatment with any medication to treat alcobolism within 6 months of rapdoenization; (e) concomitant psychiatric disorders evaluated with the Mini International Neuropsychiatric Interview (MINI version 5.0) [24]; (f) current use of any psychotropic drugs: (g) inability to give full infarmed consent; (h) clinical history of mental retardation as it redaced the accuracy of the information given.

For each study, all rubjects provided written informed consent. They were infarmed about the objectives of each study, the nature of the treatment offered, the profile of medications tested, and that the medications they would receive would be chosen at 


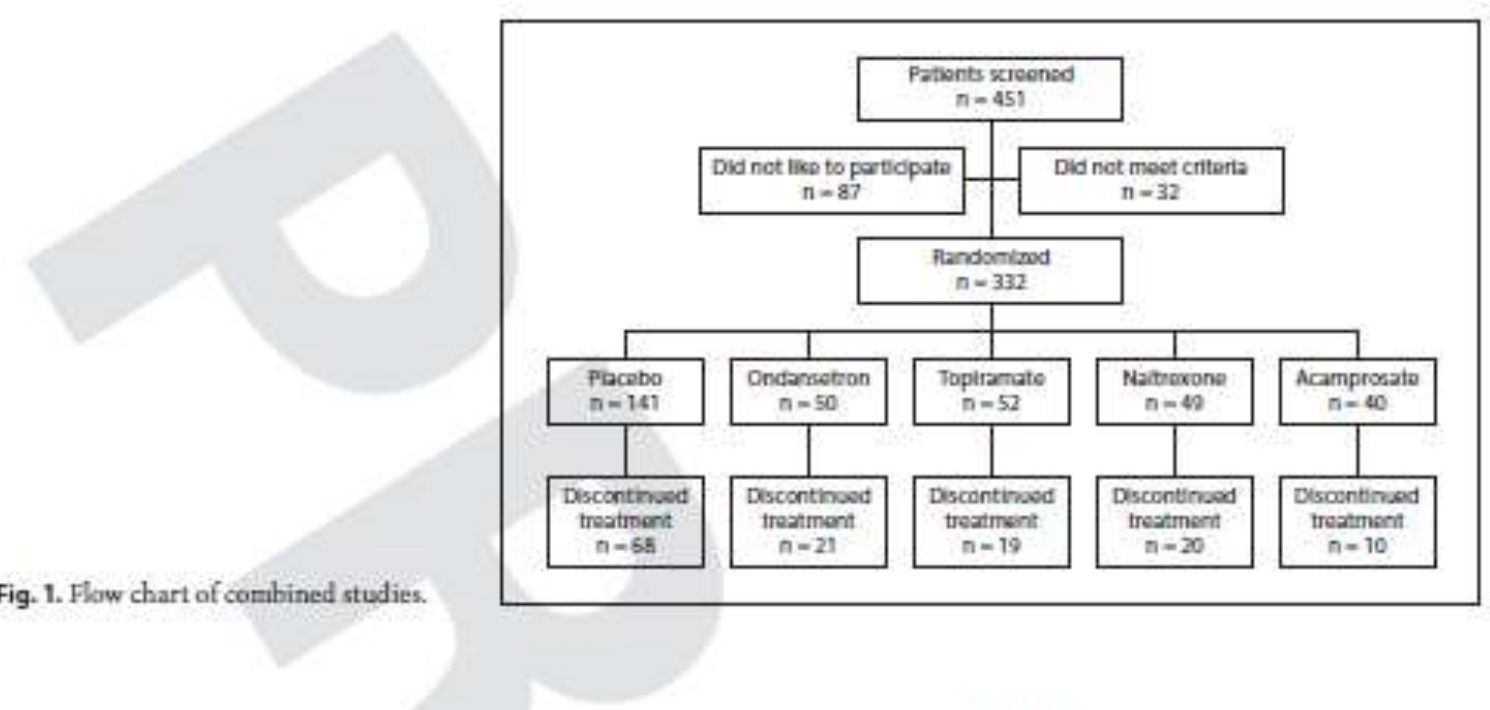

random. All putients were assured about the confidentiality of the data and were informed that they were free to withdraw their consent and discontinue participation in the studies at any time with out prejudice to their continued medical care. Each study was ap prowed by the Ethics Comumittee of the Clinical Haspital of the University of Sào Paub, Brazil

All participants were encouraged to purticipute in Alcobolics Anonymous $(A \mathrm{~A})$ groups but this was not an obligatory conditinn of taking part in these trials.

The present combined sample included 332 men, aged between 21 and 65 (average 43.23; SD 8.97). About 56\% were mar ried, $63 \%$ were white, $57 \%$ had not reached high school, and $68 \%$ were Christian. The mean monthly income (in 'Reais', the Brazil ian currency) was 969 (SD $=989.96)$. 226 subjects $(68 \% 6)$ reported being smokers.

\section{Mensures}

In the first interview for each trial, after a full history and dinical examination, patients who fulfilled entry criteria were evaluated. Sociodemographic data and lifetime drinking history. such as family antecedents of aloohol problems, daily intake of alcohol in grams, drinking onset age, problem drinking onset age, and duration of problem drinking (in years) were obtained in a standardized semistructured interview commonly used in the therapeutic setting of the Interdisciplinary Group of Studies on Alcohol and Drugs of the Clinical Hospital of the University of Sào Paub, Brszil Also, subjects were separated as being either EOA or LOA (according to the age of problem drinking $<25$ or $\geq 25$ years, respectively), derived from a rigorous evaluation of the drinker profile $[25]$

All patientr were evaluated with the Short Aloobol Dependence Data (SADD) [26], and the Hamilton Depressicin Rating Scale [27] at the finst interview. The Obsessive-Carnpulsive Drinking Scale (OCDS) [28] was not applied in acamprosate study anly. The UKU Side Ffffect Rating Scale [29] was applied at each study visit, after the baseline assessment. Blood wis taken for rautine full blood count and liver function tests.

A weighting scale was adopted to evaluate family alcobulism. The following grade was used 0.5 points for first-degree relatives and 0.25 points for seccind-degree relatives. A rigorous analysis of the incidence of alcohol dependence in first- and second-degree relatives was done.

Also, the participants were questioned about their current average daily consumption of beer, spirits, and wine, with regard to duration of uve and time of drinking (morning, afternoon, or nightl. Beer preference drinkers were then defined as those who drank mone beer than spirits or wine, and vice versa for spirits and wine preference drinkers. For 2 more precise classification, we defined a particular type of alcobolic beverage as 'predominant' if the consuraption of that type of beverage accounted for twothirds or more of the total of ethanol consumed during the last year. This chassification was used in a previous study [30].

At each appointment, the purticipants were also questioned about their participation in $\mathrm{AA}$ and those that attended $\mathrm{AA}$ once a week at least were considered to be adherent to this self help group

\section{Procedure}

All patients underwent a 2 -weck detoxification period prior to the initiation of all dauble-blind trials. This period was canducted on an outpatient basis and the patients were given medications, such as lorazepun up to $6 \mathrm{mg} / \mathrm{day}$ and vitamin $\mathrm{B}_{\mathrm{i}} 300 \mathrm{mg} / \mathrm{day}$, in case of manifesting withdrawal symptoms, laboratory examinations, inchuding Liver function, were collected daring this period. The patients included in these studies manifested from minimal to moderate withdrawal symptams, which allowed thern to be treated an an outpatient basis.

At exch appointment, all patients received standardixed and munualized brief cognitive behavioral interventions. The overall goal of these interventians was to increase the person's ability to cope with high-risk situations that could precipitate relupses During the trials, the patients were recommended manitoring good and bad daily situations during all treatment and this was discussed with their doctors and, when possible, related to the 
Table 1. Division of subjests intn two clusten ( $K$-means method, with sillhudutte inder $>0.5)$

\begin{tabular}{|c|c|c|c|c|}
\hline Types: & $\begin{array}{l}\text { Age at onset of } \\
\text { dependence }\end{array}$ & $\begin{array}{l}\text { Family history of } \\
\text { alcobolism }\end{array}$ & SADD & HDRS \\
\hline Type $1(50.936)(n=169)$ & $36.20(9.84)$ & $0.43(0.11)$ & $25.27(7.72)$ & $10.01(6.43)$ \\
\hline Type $2(49.16)(n=163)$ & $28.75(6.71)$ & $0.47(0.09)$ & $33.17(7.16)$ & $7.82(5.63)$ \\
\hline $\mathrm{F}$ & $64.52 *$ & $5.28^{*}$ & $93.23 *$ & $10.83^{* *}$ \\
\hline
\end{tabular}

drinking behaviat. The following topica were standardixed and applied to each patient during this treatment: management of negative mood, assertiveness, drink refasal akills, enhancement of social support networks and relapse prevention.

For each trial, all capsules were adequately manufictured in order to show identical appearances and to avoid any doubleblind violation.

In the present study, the outcome criterion was to evaluate the retention in the treatments. Dropout rates were evaluated from the moment each active treatment was started. Three reasons for dropping out were considered: (a) 'refuse to continue' (the patient affirmed that he wanted to stop that type of treatment and to try others, e.g. psychotherapy only), (b) 'protocol violation' (the patient used other pharmacologic drugs during the studies), and (c) 'lost ta follow-up' (the patient gave up follawing the studies and did not manifest any desire to be treated differeatly). The patients who remained on treatment for all 12 weeks were considered completern. Fatients who did not attend fallow-up were considered to have dropped out of the trials.

Data Analysis

The division of patients into homogeneous groups was made on the basis of $K$-meanscluster analysis, in line with other authors [31] - The most important theoretical premise underlying the use of cluster analysis in this work is the concept of the 'type' of an alcoholic as a syndrane including a set of characteristics simultaneously. The average silhouette width was used to decide the number of clusters to be selected. The cluster analysis was based an such clinical factors: family alcoholism, problem drinking onset age, severity of alcohol dependence (SADD), and depressive symptom mean levels (HDRS). These variahles were chosen because of their importance in elaborating preexisting chusters of slcobolics, taking into account genetic aspects (family history). characteristics of alcohol dependence fonset age and severity of dependence), and presence of psychopathology (depressina symptoms) from a dimensional perspective [31].

Differences among continuous variables were determined using parametric or non-parametric tests, according to Levene's criteria. Categorical variables were compared by using the $\chi^{2}$ test or Fisher's exact test, following the Monte Carlo method. Whenever necessary, post-hoc tests were performed by using Bonferroni and Yates' correction for continuour and categorical variahles, respectively. Also, a direct logistic regression was performed on group status (completers and discontinuers) as outcome and three predictors alcoholisar cluster, medication groups, and purticipution in an AA group. These independent wariables were chosen because they could influence the retention rates in the treatments. Interaction testa were also performed to detect influence of alcoholistn clusters on medication groups and vice wersa. For all stztistical testa performed, differences arnong groups were accepted as signifucant if they achieved the 0.05 lerd with two-tailod tests

\section{Results}

\section{Analysis of Typology}

The number of clusters was determined by using the silhouette index with Euclidean distance. In fact, to get an idea of how well separated the resulting clusters are, we made a silhouette plot using the cluster indices output from $\mathrm{K}$-means. The silhouette plot displays a measure of how close each point in one cluster is to points in the neighboring clusters. Two clusters generated a silhouette index $>0.5$ while 3 and 4 clusters generated silhouette indices $<0.5$.

Table 1 shows the effect of division of subjects into two dusters. Unifactorial results of analyses of variance show that the variables, taken into consideration independently, distinguish the two clusters significantly. People belonging to duster 2 are characterized by earlier problem drinking onset age, higher severity of alcohol dependence, more family alcoholism, and fewer depression levels than cluster 1 .

\section{Characteristics between Two Clusters of Alcoholics}

As shown in table 2, there were no significant differences between both clusters in terms of race, educational level, previous treatments for alcoholism, previous participation in AA, preferential beverage type, medication groups, tobacco consumption, and the following liver function tests: $\gamma$-glutamyl transferase, aspartate aminotransferase, and mean cellular volume. Conversely, subjects included in cluster 2 reported being younger and 
Table 2. Baseline characteristics between two alcaholism clustern

\begin{tabular}{|c|c|c|c|c|}
\hline Variables & $\begin{array}{l}\text { Type I } \\
(n=1(\theta)\end{array}$ & $\begin{array}{l}\text { Type 2 } \\
\langle\mathrm{n}=163)\end{array}$ & Test & p \\
\hline Age, years, mean (SD) & $49.99(5.54)$ & $36.21(5,93)$ & $\mathrm{t}=21.89,330 \mathrm{df}$ & $<0.01 *$ \\
\hline \multicolumn{5}{|l|}{ Marital status, $n(8)$} \\
\hline Married & $112(66.27)$ & $75(46.01)$ & \multirow{3}{*}{$\chi^{2}=15.72,2 \mathrm{df}$} & \multirow{3}{*}{$<0.01 *$} \\
\hline Single & $18(10.65)$ & $38(23.31)$ & & \\
\hline Separated/widowed & $39(2308)$ & $50(30.68)$ & & \\
\hline \multicolumn{5}{|l|}{ Race, $n(s)$} \\
\hline White & $112(66.27)$ & $96(58.90)$ & \multirow{3}{*}{$\chi^{2}=3.21,2 \mathrm{~d} f$} & \multirow{3}{*}{0.20} \\
\hline Black & $15(8.8 B)$ & $24(14.72)$ & & \\
\hline Mixed race & $42(24.85)$ & $43(26.38)$ & & \\
\hline \multicolumn{5}{|l|}{ Education, $n(\%)$} \\
\hline 12 th grade or less & $96(56.81)$ & $93(57.06)$ & \multirow{2}{*}{$x^{2}<0.01,1 \mathrm{df}$} & \multirow{2}{*}{0.96} \\
\hline High school or more & $73(43.19)$ & $70(42.94)$ & & \\
\hline Quantity of ethanol per day. $\mathrm{g}^{2}$, mean (SD) & $266.98(153.47)$ & $352.08(179.84)$ & $\mathrm{t}=-4.64,330 \mathrm{df}$ & $<0.01 *$ \\
\hline Subjects with bigh severity of alcabolism ( 220 on SADD), n (K) & $120(71.01)$ & $156(95.70)$ & $\chi^{2}=36.10,1 \mathrm{df}$ & $<0.01 \%$ \\
\hline Years since aloohol-related problems occurred, mean (SD) & $13.78(9.81)$ & $7.45(5.31)$ & $\mathrm{U}=8,543$ & $<0.01 *$ \\
\hline Previous treatments for alooholism, $n\left(\gamma_{1}\right)$ & $94(55.62)$ & $88(53.99)$ & $x^{2}=0.09,1 \mathrm{df}$ & 0.76 \\
\hline Previous $A$ A attendance, $\mathrm{n}(\mathrm{S})$ & $48(28,40)$ & $45(27.61)$ & $\bar{\chi}^{2}=0.03,1 \mathrm{df}$ & 0.87 \\
\hline Manthly income (Reais, Braxilian currency), me & $1,028.10(1,039.43)$ & $905.95(935.05)$ & $\mathrm{t}=1.12,330 \mathrm{df}$ & 0.26 \\
\hline Early-onset alcobolics, n (W) & $22(1302)$ & $49(30.06)$ & $\mathrm{x}^{2}=14.34,1 \mathrm{df}$ & $<0.01 *$ \\
\hline Subjects with depressive symptoms ( $>7$ on HDRS), n (v) & $94(55.62)$ & $74(45.40)$ & $\chi^{2}=3,47,1 \mathrm{df}$ & 0.05 \\
\hline \multirow[t]{2}{*}{ First-degree relatives with alcobol problems, n ( $(\mathrm{s})$} & $131(77.51)$ & $143(87.73)$ & $\chi^{2}=6.01,1 \mathrm{df}$ & $0.01^{*}$ \\
\hline & & & \multirow{4}{*}{$x^{2}=1.39,2 \mathrm{df}$} & \multirow{4}{*}{0.55} \\
\hline Spirits & $117(69.23)$ & $122(74.85)$ & & \\
\hline Beer & $49(23,99)$ & $39(23.93)$ & & \\
\hline Wine & $3(1.78)$ & $2(1.22)$ & & \\
\hline \multicolumn{5}{|l|}{ Medication groups, $n$ (\%) } \\
\hline Placebo & $68(40.24)$ & $73(44.78)$ & \multirow{5}{*}{$x^{2}=1.38,4 \mathrm{df}$} & \multirow{5}{*}{0.85} \\
\hline Acamprosate & $19(11.24)$ & $21(12.89)$ & & \\
\hline Topiramate & $28(16.57)$ & $24(14.72)$ & & \\
\hline Naltremone & $26(15.38)$ & $23(14.11)$ & & \\
\hline Ondansetron & $28(16.57)$ & $22(13.50)$ & & \\
\hline $\mathrm{OCDS}^{b}, \operatorname{mean}(\mathrm{SD})$ & $43.52(11.54)$ & $53.43(10.66)$ & $\mathrm{t}=-7.09,255 \mathrm{df}$ & $<0.01 *$ \\
\hline Srooking alcaholics, $\mathrm{D}(\%)$ & $119(70.41)$ & $107(65.64)$ & $\chi^{2}=0.87,1 \mathrm{df}$ & 0.35 \\
\hline Plasma GGI, U/1 (reference range 8-61), mean (SD) & $130.26(201.81)$ & $160.24(274.67)$ & $\mathrm{t}=-1.13,330 \mathrm{df}$ & 0.26 \\
\hline Plasma ALT, U/1 (reference range $\angle 41$ ), mean (SD) & $33.12(22.19)$ & $42.83(34.16)$ & $\mathrm{U}=10,779.50$ & $<0,01^{*+}$ \\
\hline Plasma AST, U/ (reference range < 37 ), mean (SD) & $37.22(26.52)$ & $48.57(49.25)$ & $\mathrm{U}=11,983.50$ & 0.21 \\
\hline Plasma MCV, fl (reference range 80-100), mean (SD) & $94.60(6.87)$ & $94.98(7.09)$ & $t=-10.48,330 \mathrm{df}$ & 0.63 \\
\hline
\end{tabular}

$* p<0.05 ; * * 0<0.01$

"Alcohol usage during the last 3 monthis preceding each study. "OCDS was not applied in the acamprosate study.

more frequently single, drinking a higher quantity of ethanol, having a shorter drinking career than subjects in cluster 1 , and having more first-degree relatives affected by alcoholism. In addition, cluster 2 subjects showed higher scores on OCDS and higher alanine aminotransferase mean levels, reinforcing their higher severity when compared to cluster 1.

\section{Reasons for Discontinuing the Studies}

As shown in table 3, there were no significant differences between both clusters as to the main reasons for retention in the studies, Also, there were no significant differences within each cluster and between both clusters within each medication group. 
Table 3. Reasons for discontinuation of studies

\begin{tabular}{|c|c|c|c|c|c|c|c|c|c|}
\hline Custen & $\begin{array}{l}\text { Placebo } \\
(n=68)\end{array}$ & $\begin{array}{l}\text { Ondareeiron } \\
(0-2 i)\end{array}$ & $\begin{array}{l}\text { Acamprosate } \\
(\mathrm{n}-10)\end{array}$ & $\begin{array}{l}\text { Naltrisone } \\
(\mathrm{n}-20)\end{array}$ & $\begin{array}{l}\text { Topiramate } \\
(\mathrm{n}-19)\end{array}$ & Tes: & p & Teat & F \\
\hline \multicolumn{10}{|l|}{ Chaster $l$} \\
\hline Protncol violation, $n(\phi)$ & $5(7.35)$ & $2(9.52)$ & 0 & 0 & $2(10.53)$ & $x^{2}=8.91,8 d f$ & 0.30 & \multirow{6}{*}{$x^{2}-0,76,2 \mathrm{dr}$} & \multirow{6}{*}{ 0.67 } \\
\hline Defuse is cuotinue, $n$ ( $(\delta)$ & $2(294)$ & $(4.76)$ & 0 & $1(5)$ & $3(15.79)$ & & & & \\
\hline Total & $29(42.64)$ & $4(38.09)$ & $1(10)$ & $10\{50\}$ & $9(47.37)$ & & & & \\
\hline Protocol violution, $\mathrm{n}(\boldsymbol{*})$ & $6(B .82)$. & $5(23.81)$ & $1(10)$ & $1(5)$ & $3(15.79)$ & \multirow{3}{*}{$x^{2}=7.42,8 d f$} & \multirow[t]{3}{*}{0.02} & & \\
\hline Plefuse to continue, $n(x)$ & $3(4.42)$ & 0 & $2(20)$ & $i(5)$ & $t(5.26)$ & & & & \\
\hline Total & $39(57.36)$ & 13 (6t:.91) & $9(90)$ & $10(50)$ & $10(5263)$ & & & & \\
\hline Test: & \multicolumn{5}{|c|}{$x^{2}=0.20,2$ df $x^{2}-1.78,2 d f x^{2}-1.52,2$ df $x^{2}-1.24,2 d f x^{2}-1.54,2$ dr } & & & & \\
\hline$p$ & 20.99 & 0.60 & $>0.99$ & 20.99 & 0.59 & & & & \\
\hline
\end{tabular}

Table 4. Participation in AA groups

\begin{tabular}{|c|c|c|c|c|c|c|c|c|}
\hline Clusters & $\begin{array}{l}\text { Placebo } \\
(n=141)\end{array}$ & $\begin{array}{l}\text { Ondansetron } \\
(n=50)\end{array}$ & $\begin{array}{l}\text { Acamprosate } \\
(n=60)\end{array}$ & $\begin{array}{l}\text { Naltrexone } \\
(n=49)\end{array}$ & $\begin{array}{l}\text { Topiramate } \\
(\mathrm{n}=52)\end{array}$ & Test: & Test ${ }^{4}$ & p \\
\hline Cluster 1 & & & & & & & \multirow{4}{*}{$\chi^{2}=0.05,1 \mathrm{df}$} & \multirow{4}{*}{0.82} \\
\hline Yes & $12(8.51)$ & $6(12)$ & $12(30)$ & $1(2.04)$ & $7(13,46)$ & $x^{2}=21.55,4 \mathrm{df}<0.01 *$ & & \\
\hline Cluster 2 & & & & & & \multirow[b]{2}{*}{$\chi^{2}=18.10,4 \mathrm{df}<0.01 *$} & & \\
\hline Yes & $20\langle 14.18\rangle$ & $1(2)$ & $10(25)$ & $1(2.04)$ & $3(5.77)$ & & & \\
\hline Test ${ }^{5}$ & \multicolumn{6}{|c|}{$\chi^{2}=1.91,1$ df $\chi^{2}=2.92,1$ df $\chi^{2}=0.97,1$ df $\chi^{2}<0,01,1$ df $\chi^{2}=130,1$ df } & & \\
\hline $\mathrm{p}$ & 0.17 & 0.12 & 0.32 & $>0.99$ & \multicolumn{2}{|l|}{0.31} & & \\
\hline \multicolumn{7}{|c|}{$\begin{array}{l}* \mathrm{p}<0.01 \text {. } \\
{ }^{2} \text { Tests within each claster, comparing participation in } \mathrm{AA} \text { among medication groups. } \\
\text { "Test comparing both clusters as to participation in AA. } \\
\text { "Tests compuring purticipation in AA between hoth clusters within esch medication group. }\end{array}$} & & \\
\hline
\end{tabular}

\section{Participation in AA Groups}

As shown in table 4, there were no significant differences between both clusters as to participation in AA. However, the participation in AA significantly varied as a function of medication groups within each alcoholism cluster. After Yates' correction for the cluster 1, subjects who received acamprosate participated in AA more frequently than those that received placebo, ondansetron, naltrexone, and topiramate $\left(\chi^{2}=13.20,1 \mathrm{df}, \mathrm{p}<0.01\right.$; $x^{2}=6.67,1 \mathrm{df}, \mathrm{p}<0.01 ; x^{2}=16.02,1 \mathrm{df}, \mathrm{p}<0.01 ; \mathrm{x}^{2}=5.35$,
$1 \mathrm{df}, \mathrm{p}=0.02$, respectively). In the same way, after Yates correction for the cluster 2 , subjects that received acamprosate participated in AA more frequently than those that received ondansetron, naltrexone, and topiramate $6 \chi^{2}=8.33,1 \mathrm{df}, \mathrm{p}<0.01 ; \chi^{2}=8.78,1 \mathrm{df}, \mathrm{p}<0.01 ; \chi^{2}=5.12$. $1 \mathrm{df}, \mathrm{p}=0.02$, respectively). Conversely, subjects in cluster 2 who received placebo participated in AA more frequently than those that received ondansetron and naltrexone $\left(x^{2}=3.89,1 \mathrm{df}, \mathrm{p}=0.049 ; \mathrm{x}^{2}=4.17,1 \mathrm{df}, \mathrm{p}=0.04\right.$, respectively). 
Table 5. Effects of alcohalism clusters, medication used and purticipation in AA groups on the retention in treatment

\begin{tabular}{|c|c|c|c|c|c|c|}
\hline Variables & SE & Wald & df & p & OR & $95 \%$ CI \\
\hline Constint & 0.22 & 0.54 & 1 & 0.46 & L.18 & - \\
\hline Chuster 2 & 0.23 & 8.72 & 1 & $<0.01 *$ & 0.50 & $0.31-0.79$ \\
\hline Medication group & - & 5.38 & 4 & 0.25 & - & - \\
\hline Ondansetron & 0.35 & 0.93 & 1 & 0.33 & L40 & $0.71-2.76$ \\
\hline Acumprosate & 0.43 & 3.08 & 1 & 0.08 & 2.12 & $0.92-4.90$ \\
\hline Naltrexone & 0.35 & 2.08 & 1 & 0.15 & 1.65 & $0.83-3.28$ \\
\hline Topiranate & 0.35 & 2.37 & 1 & 0.12 & 1.71 & $0.86-3.37$ \\
\hline Participation in AA & 0.33 & 14.08 & 1 & $<0.01 * *$ & 3.51 & $1.82-6.76$ \\
\hline
\end{tabular}

${ }^{*} \mathrm{P}<0.01$.

Table 6. Effects of medication used, participation in AA groups, and the cluster-related variables an treatment retention

\begin{tabular}{|c|c|c|c|c|c|c|}
\hline Variables & SE: & Wald & df & $\mathrm{p}$ & OR & $95 \% \mathrm{CI}$ \\
\hline Constint & 0.48 & 1.74 & I & 0.19 & 0.53 & - \\
\hline Cluster 2 & 0.27 & 9.16 & 1 & $<0.01 *$ & 0.45 & $0.26-0.75$ \\
\hline Medication group & - & 3.83 & 4 & 0.43 & - & - \\
\hline Ondansetron & 0.37 & 158 & I & 0.21 & 1.59 & $0.77-3.27$ \\
\hline Acamprosate & 0.44 & 1.39 & 1 & 0.24 & 1,68 & $0.71-3.98$ \\
\hline Naltrexone & 0.36 & 1.70 & I & 0.19 & 1,59 & $0.79-3.20$ \\
\hline Topiramate & 0.35 & 1.59 & 1 & 0.21 & 1.56 & $0.78-3.11$ \\
\hline Participation in $\mathrm{AA}$ & 0.34 & 11.39 & 1 & $\infty 0.01 *$ & 3.19 & $1.63-6.25$ \\
\hline First-degree relatives & 0.32 & c.001 & 1 & 0.94 & 1.02 & $0.55-1.91$ \\
\hline Mald to moderate depression & 0.25 & 3.67 & 1 & 0.06 & 0.62 & $0.38-1.01$ \\
\hline Categorical SADD & 0.34 & 2.31 & I & 0.13 & 1.68 & $0.86-3.26$ \\
\hline Early-onset alcobolics & 0.31 & 2.69 & I & 0.10 & 0.60 & $0.33-1.10$ \\
\hline
\end{tabular}

\section{Alcoholisen Clusters, Medication Groups, and}

Participation in AA

As shown in table 5, we performed a direct logistic regression to analyze the influence of alcoholism cluster, medication groups, and participation in AA in the treatment retention. In the direct logistic regression, a test of full model with all predictors against a constant-only model was statistically significant, $\chi^{2}=32.59,6 \mathrm{df}, \mathrm{p}<$ 0.01 . The variance in group membership accounted for was marginal, with Nagelkerke $R^{2}=0.13$. The overall success rate for prediction was $63.3 \%$. According to Wald criterion, subjects in cluster 2 showed higher risk of dis- continuing the treatments, independently of the medication groups and participation in AA (Wald $=8.72,1 \mathrm{df}$, $\mathrm{p}<0.01, \mathrm{OR}=0.50,95 \% \mathrm{CI}=0.31-0.79)$. Also, participating in AA increased the chance of completing the treatment, independently of medication groups and clusters of alcoholism (Wald $=14.08,1 \mathrm{df}, \mathrm{p}<0.01, \mathrm{OR}=3.51,95 \%$ $\mathrm{Cl}=1.82-6,76)$. We checked the model fit using Hosmer and Lemeshow's test $\left(x^{2}=1.49,7 \mathrm{df}, \mathrm{p}=0.98\right)$.

We verified the interaction between alcoholism clusters and medication groups. There was no significant. interaction between cluster 2 and medication groups (Wald $=3.08,4 \mathrm{df}, \mathrm{p}=0.54$ ). Conwersely, there was sig- 
nuncant mueracton petween ciuster 1 and medicanon groups (Wald $=12.29,4 \mathrm{df}_{3} \mathrm{p}=0.01$, particularly in acamprosate group $($ Wald $=7.28,1 \mathrm{df}, \mathrm{p}<0.01, \mathrm{OR}=16.36$ $95 \% \mathrm{CI}=2.15-124.61$ ). This interaction can be explained by the fact that only 1 out of 10 non-adherent subjects in acamprosate group belonged to cluster 1 .

\section{Cluster-Related Variables, Medication Groups, and Participation in AA}

In order to verify if the variables used to construct our clusters predict treatment retention independently, we transformed them into categorical ones. This transformation was carried out because yes/no variables are more commonly used for clinical or research purpose than continuous ones; in addition, there are validated cutoffs for the instruments (SADD and HDRS) we applied. A score $>20$ on SADD suggests severe alcohol dependence and a score $>7$ on HDRS suggests presence of mild depressive disorder. We defined early versus LOA in accordance with the age of problem drinking $<25$ or $\geq 25$ years, respectively. As to 'family history', we divided our sample into subjects with or without first-degree relatives affected by alcoholism.

As shown in table 6 , subjects in cluster 2 continued to show higher risk of discontinuing the treatment, while attendance at AA increased the chance of higher treatment retention. No other variable showed significant effects on retention in treatment. In this analysis, a test of full model with all predictors was statistically significant $\left(x^{2}=41.85,10 \mathrm{df}, \mathrm{p}<0.01\right)$. The variance in group membership accounted for was marginal, with Nagelkerke $R^{2}=0.16$ and the overall success rate for prediction was 65.1\%. Also, the model fit using Hosmer and Lemeshow's test was checked $\left(\chi^{2}=4.38,8 d f, p=0.82\right)$.

\section{Discussion}

When dividing subjects into two typological groups it has been found that cluster 2 persons were characterized by earlier onset age, more family alcoholism, higher alcoholism severity, and less depression symptoms than cluster 1 persons. Cluster 2 alcoholics also showed a higher chance of discontinuing the treatment, independently of different medications used and participation in AA. In addition, participation in A.A was a significant factor related to treatment retention, independently of typological groups and medications used. The clusters and participation in A.A remained significantly related to treatment retention even after being controlled for other ways of
Categorizatuon or arconouscs, sucn as early- versus rate-onset alcoholism, having or not having first-degree relatives affected by alcoholism, having or not having mild depression symptoms, and showing severe or moderate alcohol dependence. Considering diverse classifications of alcoholics to date, our clusters seem to be similar to those proposed by Babor et al. [15].

It is important to note that, despite the high alcohol dependence severity, our sample is relatively 'benign', given that no subjects had other serious psychiatric problems such as other drug misuse and severe depression. This may be confirmed by the fact that all subjects were candidates for outpatient treatment. In addition, we must bear in mind that only $21 \%$ of our participants were EOA. and this might have hindered the effect of this subgroup on treatment retention, mainly when our sample was categorized in early versus late onsetters.

Anyway, alcoholism is a multifactorial disorder involving biological, genetic, and psychosocial interactions. Hence, multiple variables can be necessary to classify this extremely complex population in order to avoid overlap of characteristics, at least to some extent. It is recognized that subjects classified as Cloninger's type I or II or Babor's type A or B represent heterogeneous subgroups and an overlap of symptoms and characteristics may be seen between the types. However, the weight of genetic and neurobiological factors seems to differentiate each other and result in different therapeutic responses [9].

Diverse studies have already attempted to identify both client and treatment predictors of retention in substance use treatment. There is some evidence that the following client-centered factors are related to early discontinuation of treatment: young and single patients, high severity of substance use, and lack of family stability. With regard to treatment-centered factors, positive therapeutic alliance, good clinician experience, and proactive participation of family member have been associated with lower attrition rates [32]. On the other hand, studies have shown mixed results with regard to depression symptoms [33]. It is important to stress that no participant was severely depressed or required specific treatment for depression in our present study, given that depression was an exclusion criterion for the three trials. As a general rule, the treatment program quality and specific client motivations and characteristics may contribute to retention rates.

Active medications did not influence treatment retention in the present study; despite this, the acamprosate group had a better (but not significant) effect on completion of treatment. Although the interaction between the

3. Eur Addict Res Baltieri/Corrka Pilho 
cluster 1 and acamprosate group was statistically significant, the confidence interval was extremely wide, making any statement about the effect of this interaction on retention treatment unreliable. Other studies have already shown that treatments with opioid antagonists [34-36] topiramate $[37,38]$, and ondansetron alone or in combination with naltrexone $[5,39]$ are not associated with increased retention in treatment, when compared with placebo. On the other hand, treatment with acamprosate seems to be associated with significantly greater retention in treatment relative to placebo when participants are abstinent for 4 days or more prior to commencement of medication [40]. Anyway, even combinations of two medications for alcoholism have not shown any effect on retention in treatment compared with either of the individual pharmacotherapies alone $[41,42]$.

In our study, the participation in AA was significantly related to retention in treatment. To date, there is no conclusive scientific evidence that participation in AA keeps patients longer in treatment [43]. In general, one of the difficulties of evaluating the effectiveness of participa tion in AA is the self-selection bias of those who participate [44]. Since individuals self-select themselves for participation in AA, otherwise known as selection bias, it is not clear whether there are personality or motivational factors related to those that decide to join this self-help group. Some authors have reported that alcoholics who attend AA are typically more sociable and affiliative, guilty over past behavior, physically healthier, and social ly stable [45]. Conversely, other authors affirm that attendance at AA is more common among racial and ethnic minority groups, those with lower income, and those with unstable employment [46]. Although these generalizations can be problematic and doubtful, some characteristics attributed to AA participants can have a certain level of acceptability, given the inherent characteristics of self-help groups. In fact, participating in AA was not an obligatory condition to partake in any of our trials, despite the encouragement given by researchers. This may mean that the most motivated and affiliative patients decided to partake in AA with the aim of improving their coping skills and changing their friendship networks [47]. Other authors suggest that success in AA is associated with frequent and continued attendance and not with motivation per se [48]

Despite the heterogeneity of our clients, many therapeutic programs offer only a single type of treatment. With this 'one size fits all' model, variations in retention have been commonly attributed to client factors or characteristics. Although this may be true to some extent, health services should broaden the scope of services offered to meet heterogeneous needs of clients, and identify treatment practices and therapists which improve retention. Information about patients' characteristics linked to non-compliance or dropout should be used to make treatment programs more responsive and attractive, combining pharmacologic agents with more intensive and diversified psychosocial interventions. Certain approaches, such as compliance enhancement therapy and motivational interview, can be good options when combing adjunctive interventions for randomized clinical trials [49]. Strategies to improve motivation are of paramount importance in different treatment programs and they will be taken into account for future research by our group.

Probably the continuous development of typologies will contribute to determine what kind of treatment is more suitable for certain types of patients. If patients' data obtained at the beginning of treatment are useful to design a more adequate treatment, health professionals will pay higher attention to this task. On the basis of this information, it is possible to identify the population whose treatment should receive the most attention and investment. Future efforts should be made to study how the commitment to the treatment of duster 2 clients could be improved.

There were several weaknesses in this present study: (1) There were no other psychotherapeutic procedures associated with the pharmacological treatments, which could increase the retention of the patients. (2) The number of dropouts was high in all of these trials, probably as a result of their designs, which allowed patients to follow the standard community-based programs of treatment, without norms to increase patient retention. Although this approach to trial design, which allows normal life events to influence trial outcome, probably enhances external validity, it can lead to considerable difficulties in interpreting data, such as motives for relapse and premature discontinuation of follow-up. (3) Our service is tertiary, where many severe cases are referred to. This can be verified by the enormous quantity of ethanol consumed by our subjects. It is difficult to generalize our findings to a less severe alcoholic population. (4) Our research did not include women. Some studies have shown that gender difference exerts different roles in retention treatment [50], (5) The dosage of ondansetron tested (16 $\mathrm{mg} / \mathrm{day}$ ) was higher than the dosages usually investigated by other studies. This may harm the comparability to other studies. (6) Disulfiram was not tested. Studies have shown that this medication help patients maintain absti- 
nence and in treatment for longer periods [51]. (7) Our trials limited the examination of AA participation to the frequency and regularity of meeting attendance, which fails to capture the breadth of involvement in the program.

\section{References}

1. Hofinan KA, Ford IIL, Tillotsan Cl, Chai D. MeCarty D. Days to treatment and early re. tention among pabienis in tratment for alco. hol and drug disorders. Addia Behav 2oll 36:543- 547 .

2 Cossop M, Marsden I, 5 tewart D, Rolfe A. Treatment retention and $\mathrm{I}$ year ouicomes for revidential programmes in England. Drup Alcobol Depend 1999,57:59-93.

3 Hillemacher T, Theich s: Nearobiology and treatment in alcobolism - recent findings re ganding Lesch's typology of alcohol depen dence. Alcohol Alcohol 2006;43:34I-316,

4 Coninger C.R: Nearogenetic adaptive mechanima in akoholiam. Science 1987;236:410 416.

5 lohnson $\mathrm{BA}$, Roache ID, Jarors MA, et al Ondanvetron for reduction of drinking among biologically predisposed alcoholi: poticnis a randomized controlled trial. IAMA 2000;284:963-971.

6 lohnson BA, Itoache ID, Ait. Ducud N, Zanca NA, Velazquer M: Oodansetron reduce: the craving of hiologically prediposed a! cobolics. Psychopharmacology 2002, 160 $408-413$

7 Nemeroff CB, Owens MI: Neurupharmacol. cgy of parasetine. Papchopharmacol Bull 2003-37-5s-518.

8. Kiefier F, limenet-Arriero MA, Klein $\mathrm{O}$ DiehI A, Bubio C. Cloninger's typology and treatment outcome in alcohol-dependent subjects during pharmacotherayy with nal tresone. Addict Biol 200\%; 1 $12124-129$.

9 Rubio C, Ponce G, Rodriguer -fimener R, Ii mener-Arriero MA, Hoenicka 1, Palomo T Cinical predictors of response to naltresoe: in zlcohdic patienls: who benefits most from treatment with naltrexane? Alcohol A Jcohni 2005, 40:227-233.

10 Vertieul R, Lehert R, Ceerlings P, Koeter MW, van den Rrink W: Predicinrs of acampeosale efficacy results from a pooled analy. sis of seven European trials including 1,4as alcobol-dependent patientas. Psychopharmi cology 2005; 178:167-173.

11. Lesch OM. Water H. Snbtypes of alcoholism and their mie in therapy. A kohnl Aknhal $1996 ; 1=63-67$

12. Kiefer P, Helwig H, Tarnaske T, Otte C, Jahn H. Wiedemann $\mathrm{K}$ - Pharmacological relaps: peerention of aicoholism: clinical predicton of outcome. Far Addict Res 2005,11-83-91.

\section{Acknowledgement}

The autbors wish to thank The State of Sào Paulo Research Foundation (FA PSSP).
13 Lesh $O M$, Riegler $A$, Cutierree $K$, et al The European acampecosate trials: concluaions for research and therapy. I lliomed Sci $2001 ;$ E: $89-95$.

14 Chick I, Huwlent H, Mergan MY, Bitson E: United Kingdom Multicentre Acamprosale Sindy (UKMAS): a 6-mooth prospective study of acamprosate versur placebo in preventing relapse afler withdrawal from alcohal. Aloobol Alcobol 2000;35: 176-187

15 Baber-TF, Hoimasin M, Deliboca FK, et at: Types of zlcoholics, I. Evidence for in empirically derived typology based on indicaisers of velnerahility and severity. Arch $\mathrm{Cen}$ Prychiatry 1992;49:599-608.

16 Petinati HM, Volpicelfi IR, Kranzler HR, luck C, Dukatalis MD, Cnaan A. Sertraline treatmeni for alcobol dependence: interac. tive eflects of medication and alcoholic sub type. Akohul Cin Ixp Res 2000;24:1041 1049

17 Kranzler HR, Burieson IA, Beown I, Habor TH. Flucretine tralment seems in reduce the beneficial effects of esgnitive-behavinol therapy in type $\mathrm{H}$ alcoholics. Aloobal Clim Exp Res 1996;20:1534-1541.

18 Kampmen KM, Pettinati IIM, Eynd KC, ef it A double-bind, placebo-conitrolled pilot trial of quetiapine for the trealment of type $A$ and type B alcoholiam. IClin Prychophar. macol 2007;27:364-351.

19. Mclellan AT, Chalk M, Barilet 1: Outcomes, performance, and quality: what's the difference? I Subst Abuse Treat 2007;32 33L-300.

20 Fonsi E.lbreder M, de Soura e Siliva II, Pillon SC, Larajeira R: Alcobol dependence: analysis of factors associated with retention of patientsin outpatient treaiment. Aknhol A1. cohol 201 1; 46:74-76:

21 Beynon CM, McMinn AM, Marr AJ, Factins predicting drop out from, and retention in, specialist drug treatment services a case control study in the North West of England. BMC Public Ilealth 2008; $8: 149$

22 Baltieri DA, De Andrade MC Acamprosate in alcobol dependence: a randamixed controlled efficacy study in a standard clinical setting. I Stud Alcohol 2004;65-136-139.

23 Baltieri DA, D2ro FR, Ribeiro PL, de Andrade $A G$. Comparing topiramate with nal. trexone in the treatmeml of alcobol dependence. Addiction 2006-103-2n35-2044.
24 Amorim P: Mini Internaliocal Neuropsychiatric Interview (MINI): validation of a short structured diagnostic psychiatric in. utrview. Rev Bras Psiquiatr 2000; 22-106-115.

25. Miller WR, Marlat CA.Manual of the Cor prehensive Drinker Prnfile, Odessa, Psycho. Jogical Assessment Rescurces, 1984.

26 Nlaistrick D, Dunkar G, Davidnon R- Devel. opmenl of a questionnaire to measure alco. hol dependence. $\mathrm{Br}$ + Addict 1983,78:89-95.

27 Hamilton $\mathrm{M}=\mathrm{A}$ rating xale for depression. I Nearul Nearosary Pofchiatry 1960,23:5662.

28-Arton HE, Moak DH, Jatham P, The Obseswire Compulsive Drinking Scake, a self rated instrument for thequantification of houphts aboat alcohol and drinking behavior. Alco. bol Cin Exp lles 1995; 19:92-99.

29 Iingiende $\mathrm{O}$ Ahliors QXC, Bech P. Dencker S5, Egen $\mathrm{X}$ - The UXU side effect rating sale. A new compochensive rating wale for psychotropic drups and a cross-sectional study of side effects in neurnleptic-treated patients. Acta Pspchizar Scand Suppl 19az:334:1-100.

30 Haltieri DA, Daro FR, Itibeiro PL., De Andrade MG: The role of alcoholic beverage pteference in the sererity of alcohol dependence and atherence to the ireatment. Nico. hol 2009,43, \$B5-195.

31 Hauser J, Dybalowski f: Three clusters of malealcobolics. Drus Alcohol Depend 1997; 43:243-250:

32 Cirafi ES, Morgan TI, Epstein IE, e al: Engepement and restention in outpatient alcobolism trealment for women. Am I Addict 2009:18:277-28B.

33 Charner DA, Parherckis AM, Neqrele 1C Gill KJ: The impact of depossion on the out come of addictions treatment. IS Suhat A buse Treat 1998; 15:123-130.

34 Heinala P, Alhe H, Kiranmaa K, lonnqvist I. Kanppasimi K, Sindair ID. Taneted use of naliresone withoul peior deterification in the ireatment of alcohbl dependence: a facto. rial double blind placebo-controlled irial. I Clin Purchoph2rmacol 2001-21-287-792.

35 Srivaramott $M$, Tanuarasin $N$ : Naltrexone for the ireatment of alcoholism: a melsanalysis of raniomized conitnolled trials. Int 1Neuropsychopharmacol $2005,5-2 \pi 7-280$.

36 PosnerS, Hackl-Herrwerth A, LeucheS, Vec chi S, Srisurapanoti M, Soyka M:Opioidan. tazorists for alcohol dependeoce. Cochrane Database Syst Rev 2010;12CDo01367. 
37 Johnson HA, Rosenthal N, Capece IA et at Topiramale for trealing a kcohol dependence a randomized conirolied irial. IAMA $200 \%$ 298:1641-1651.

38 Rubio G, Martince-Ciras t, Manuanures 1 Modalation af impalsivity by fopiramate implications for the treatment of alcohol dependence, I Clin Pyychopharmacol 2no9;2s 584-559.

39 Ait-Dawad N, Johnson BA, Juvors M, Poache ID, Zanca NA Combining ondunsetron and nalirexone treats biological alcoholics: cotrobocation of self-reported drinking by se rum carbohydrate deficient transiterrin, biomarker. Alcohol Clin Exp Res 2001;26. $847-849$.

40 Kampman XM, Pettinati HM, Irnch XG, ef al: Initiating acamprosate within-detoxi fication versus port-detoxilication in the treatment of a leohol dependence. Addict Behav 2009;34-581-586.

4 Anton RF, O'Malley 5S, Ciraalo DA, et at Combined pharmacotherupies and behavioral interventions for zlcohol dependence the COMALNE study: a randomized on trolled trial. IAMA 2006;295:2003-2017.
42 Petinuti HM, Osin DW, Kampman KM, es al: A double -blind, placebo-conirolled trial combining sertraline and naltresone for treating wo-occurring depeession and alcohol dependence Am I Psychiatry 2010,167: $668-675$.

43 Ferri M, Amio L, Davoli M- Almholics Anonymous and other 12 -step programmes for alcohol dependence. Cochrane Databuse Syst Mev 2006;3.CDoosous?

44. Tonigan IS. Toscovs B. Miller WR. Metzanalyin of the literafure on Alpoholici Anunymoue sample and study characteristio moderate findingr. 1 Stud Alcohel 1996; 57:65-72

45 Finnick CD-Alcoholics Anocymoas afflia. tian peocesses and effectiveness as treatment. Aknbol Clin Erp Rea 1987;11:416423

46 Humphrefs X, Kaskutas L.A, Weisner C. The relationship of pre-treaiment Alcobolics Anonymous afflitiones with peoblem severity. social resources and treatmemt history. Drur Aknhal Depend 1999,45:123-13i.

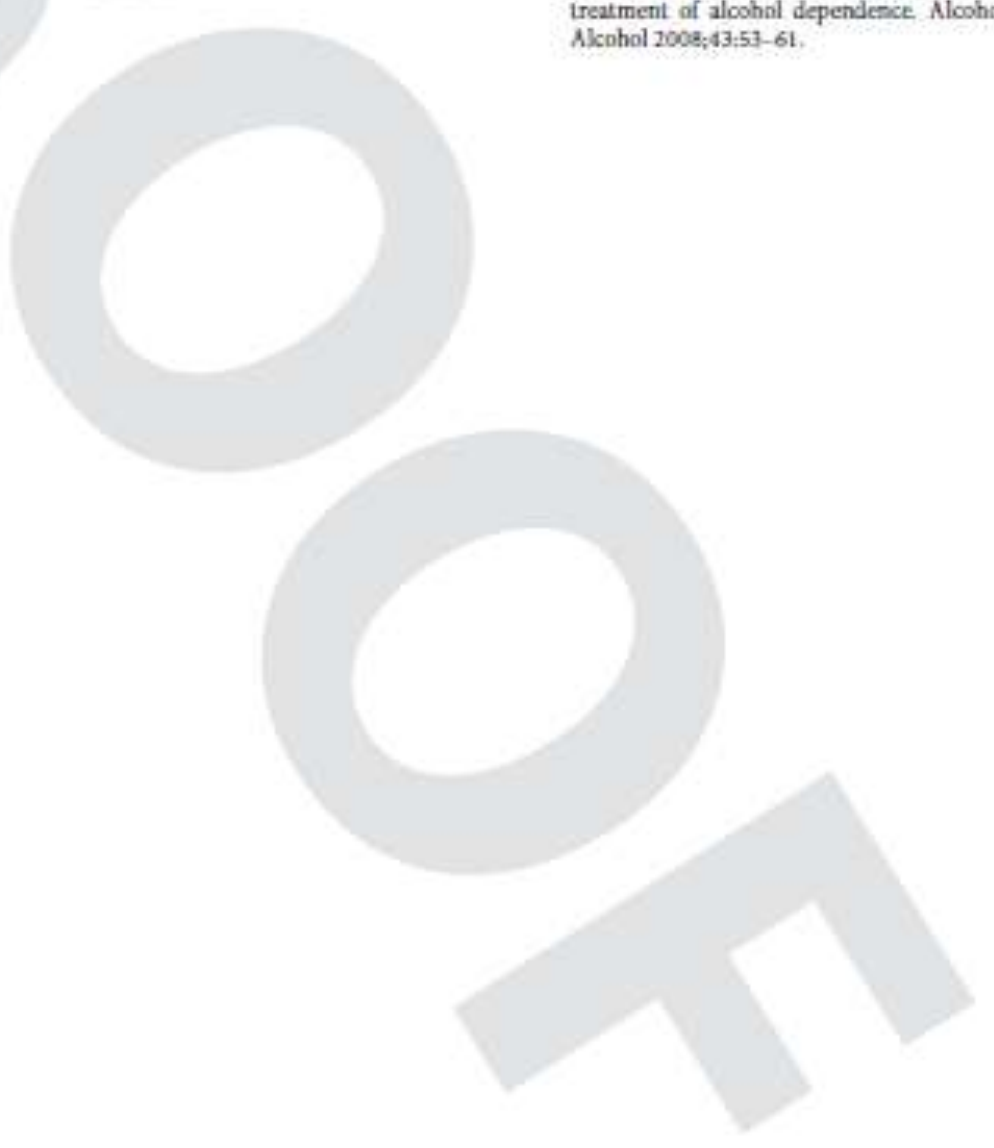

67 Humphreys K, Mankowski ES, Moos IRH, Finner IW: Do enhanced friendship networks and active coping mediate the effect of sctfhelp groups on substance abase? Ann Behar Med 1999;2l:54-60.

48 Fiorentine $\pi$, Hithouse MP. Frploriny the addilive effects of drup misuse treatment and twelve-step involvement. does twelve. step ideology matier? Subst. Use Misuse 20001-35:367-397.

49. Heffoer II, Tran $\mathrm{CQ}$. Jobrnson $\mathrm{CS}$, ef al: Combining motivational imerriewing with complianice enhancement therapy (MI. CIT): development and preliminary evalus. tion of a new, manual-guided poychosocial afiunct to alcohol dependence pharmaco. therapy. IStud Aloobol Drugr 2010;71 $\leqslant 1-70$. 50 Creenfield ST, Brooks A, Ciondon SM, et al Substance abuse treatment entry, retention, and cutcome in wornen: a review of the literature. Drug Alcobol Depend 2007;86: I- 21

51 Lakwonen E, Kuski-Jannes $A$, Salaspuro $M$, Ahtinen H, Alho $\mathrm{H}$ : A randernized, muiticenire, open-label, comparative trial of disulfiram, naltresone and acamprosale in the treatment of aloohnl dependence. Aloohol Alcohol 2008;43:53-6! 
Anexo N (Artigo publicado na Revista Brasileira de Psiquiatria)

Rev Bras Psiquiatr, 2012;34:413-421
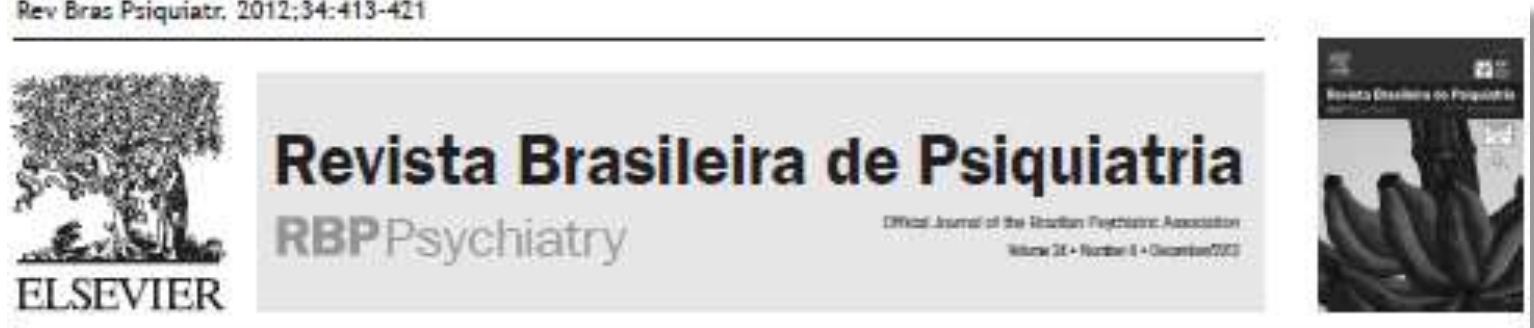

ORIGINAL ARTICLE

\section{Psychosocial and clinical predictors of retention in outpatient alcoholism treatment}

João Maria Corrêa Fitho, ${ }^{1}$ Danilo Antonio Baltieri ${ }^{1,2}$

'Department of Psychiatry of the Universidade de Sảo Paulo, Brazil

'Department of Psychiatry of Faculdade de Medicina do ABC, Santo André, SP, Brazil

Submitted on January 17, 2012; accepted on March 19, 2012

DESCRIPTORS:

Pharmaoologioal Trials:

Craving:

Aloohotios Anonymous

Groups:

Psyohosocial

Interventions

\begin{abstract}
Abstroct
Objective: One of the factors arsociated with low rates of oompliance in the treatment for alooholism seems to be the intensity of oraving for aloohol. This study aimed to evaluate the associations between aloohol oraving and biopsychosocial addiotion model-related variables and to verify whether these variables could prediot treatment retention. Methods: The sample oonsisted of 257 male alooholios who were enrolled in two different pharmacologioal trials oonduoted at the Universidade de 5 ăo Paulo in Brazill. Based on four factors measured at baseline - biological (age, race, and family alooholism), psychiatrio (depression symptoms), social (finanoial and marital status), and addiction (oraving intencity, severity of aloohol dependenoe, smoking statua, drinking history, preferential beverage, daily intake of aloohol before treatment) - direot logistio regression was performed to analyze these faotors' influence on treatment retention after controlling for medication groups and AA attendance. Results: Inoreasing age, partioipation in Alooholios Anonymour groups, and beer preferenoe among drinkers were independently assooiated with higher treatment retention. Conversely, higher scores for depression increased dropout rates. Conclusion: Health services should identify the treatment praotices and therapists that improve retention, Information about patients' oharaoteristios linked to dropouts should be studied to render treatment programs more responsive and attractive, combining pharmacologioal agents with more intensive and diversified psychosocial interventions.
\end{abstract}

Corresponding author. Darrilo Antonio Baltieri. Avenida Angelica, no, 2100, conjunto 13, CEP: 01228-200. Sào Paulo, SP, Brazil. Phone: (-55 11) 3120-6096. E-mail: dbaltierisuol.oom.br 1516-4446 - s2012 Elsevier Editora Ltda. All rights reserved. doi: $10.1016 /$ j.rbp.2012.03.003 


\section{DESCRITORES:}

Estudos olinioos:

Fissurs:

Grupos de Alooólioos

Anônimos:

Intervencóes:

Psioossociais.
Preditores psicossociais e clínicos de retençâo ao tratamento para alcoolismo

\section{Resumo}

Objetivo: Um dos fatores assoociadoa com baixas taxes de adesăo ao tratamento para alooolizmo pareoe ser a intensidade da fissura pelo alcool. Este estudo objetiva avaliar a associaçăo entre a fiszura pelo silocol e variaiveia relacionadas ao modelo biopsicossocial de dependênoia, bem oomo verifioar se estas variàveis previém retengĩo ao tratamento. Método: A amostra foi oomposta por 257 homene dependentes de aloool que participaram de dois diferentes estudos olinioos que foram desenvolvidos na Universidade de Sáo Paulo, Bracil. Baceado em quatro fatores medidos no inioio do tratamento - biológioo (idade, raca e alooolismo familiar), paiquiátrioo (sintomas depressivos), social (oondịăo econômioa e status marital) e relaciona do à dependéncia (intensidade da fissura, gravidade da dependénoia do aloool, atatus de ser fumante, tempo de consumo regular eproblematioo de bebidas alcoolicas, bebida preferencial, quantidade de etanol consumido ao dia) - um modelo de regressäo logistica direta foi desenvolvido para analisar o efeito destas variáveis sobre a retençåo ao tratamento, controlando para a influênoia das medicacóes utilizadas e da partioipap̧ăo em grupos de alcoolioos anônimoc. Resultodos: Mais idade, participagão em grupos de alooólicoz anönimos e preferéncia por cerveja foram fatores independentemente associados a maior retenģăo ao tratamento. Maior escore em deprezala aumentou a chance de abandono. Conclisüo: Servicos de saùde devem identifioar prat ticas e profissionais que proporoionem melhora nas taxas de retenqào. Informagảo sobre ac oaracteristicas dos pacientes relacionadas ao abandono devem ser vadac para tornar programas de tratamento mais eficientes e atraentes, combinando agentes farmacolögioos oom maí intensivas e diversifioadas intervenpôes psioossociais.

\section{Introduction}

The rates of compliance with treatment for alcoholism are as low as those for other chronic medical disorders. Poor treatment adherence represents a reduction in quality of life and a loss of life years for many patients. Over the last 30 years, researchers have identified several client-centered factors associated with early discontinuation of substance abuse treatment, such as youth, single social status, high severity of substance use, family alcoholism, and depression. With regard to treatment-centered factors, negative therapeutic alliance, low clinician experience, and inadequate engagement of family members in treatment have been associated with high rates of treatment abandonment and relapses during follow-up. t]

Many of these client-centered factors have been positively correlated with craving intensity. Despite the subjective nature of and diverse theories surrounding this theme, craving has been positively correlated with younger age," alcohol dependence severity, ${ }^{4}$ family alcoholism, ${ }^{5}$ and negative moods or emotional status." Other factors, such as stress exposure, ${ }^{7}$ preferred beverage, ${ }^{2}$ history of recurrent detoxifications, ${ }^{4}$ and smoking status," have also been associated with craving intensity. Hence, craving has been considered a better predictor of relapse than other variables, such as psychosocial functioning, treatment duration, and alcohol. ism severity levels."

Alcohol craving is thought to appear either from the desire to have alcohol's positive effects (i.e., positive reinforcement) or from the desire to circumvent the negative effects of withdrawal symptoms (i.e., negative reinforcement), but further models have proposed other important dimensions of craving, such as the desire and intention to consume alcohol, lack of control over alcohol use, preoccupation with drinking-related thoughts and/or behavior among others. Therefore, certain aspects of craving can better characterize the experience of some alcoholics than that of others, which can render the evaluation of craving extremely difficult." In addition, the quality and intensity of craving can vary in accordance with personal characteristics and ervironmental circumstances.

Treatments for alcoholism have been developed to reduce craving and, consequently, alcohol consumption. Currently, four agents are approved by the Food and Drug Administration to treat alcoholism: disulfiram, acamprosate, oral naltrexone, and once-monthly, injectable, extended-release naltrexone. Notwithstanding some inconsistent findings, these agents have demonstrated some ability to reduce craving and increase abstinence time. Except for disulfiram, which has an aversive mechanism of action, effective pharmacotherapies for alcohol dependence are thought to work by blocking the rewards of alcohol or by stabilizing the systems dysregulated by chronic alcohol intake, making craving less intense." In addition, off-label medications, such as topiramate and ondansetron, have also been shown to reduce craving and increase abstinence time, ${ }^{\text {as }}$ "The ability to reduce craving should then be associated with the likeliness to increase treatment retention, at least to some extent.

A range of studies have demonstrated that longer durations of treatment and treatment completion are associated with better outcomes in alcoholism-treatment programs. ${ }^{13}$ We are aware that treatment retention is not an outcome measurement on its own; however, the capacity to retain patients in active participation is a sensible measurement associated with the quality and efficacy of health care. 
Additionally, according to the UK's National Treatment Agency for Substance Misuse, retention in drug treatment is the best available measurement of treatment effectiveness. "t

in this present study, we evaluated the associations between alcohol craving (measured using the obsessive Compulsive Drinking Scale-OCDS) and diverse previcusly tested variables in the biopsychosocial addiction model. specifically, we investigated the relationship of alcohol craving with the following factors: (1) biological: age, race, and family alcoholism; (2) addiction: severity of alcohol dependence, smoking status, drinking history, preferred beverage, and daily intake of alcohol before treatment; (3) psychiatric: depression symptoms; and (4) social: financial and marital status. Additionally, we evaluated whether craving intensity and any of the above variables could predict treatment retention, when different pharmacotherapies and participation in Alcoholics Anonymous groups were also taken into account. In addition, given the role of craving intensity on attrition rates, we hypothesized that craving (measured by the oCDS) would be a strong predictive factor of treatment, even after controlling for other variables potentially correlated with this variable.

\section{Methods}

Databases of two randomized, double-blind, placebo-controlled clinical trials were combined for this joint analysis. These trials were performed to detect the efficacy of active medications in reducing drinking, promoting abstinence and decreasing cravings in alcohol-dependent cutpatients. The pharmacological treatments lasted 12 weeks. Each study was approved by the Ethics Committee of the Clinical Hospital of the Universidade de săo Paulo in Brazil. More specifically, we combined the databases from the following double-blind studies, which evaluated craving intensity by applying the obsessive compulsive Drinking scale (OCDS): (A) a trial, performed between 2004 and 2007, comparing topiramate (up to $300 \mathrm{mg} /$ day), naltrexone ( $50 \mathrm{mg} /$ day) and placebo;"t4 and $(B)$ a study, conducted between 2008 and 2010 , comparing ondansetron ( $16 \mathrm{mg} /$ day) with placebo. These trials were coordinated by the same doctor and were developed in the same clinical setting, following the same behavioral approaches and double-blind principle.

\section{Participants}

Male patients, 18-60 years of age, with an International Classification of Diseases (ICD-10; World Health Organization, 1992) diagnosis of alcohol dependence and who were enrolled as outpatients in the Assistance Sector of the interdisciplinary Group of Studies on Alcohol and Drugs at the Universidade de săo Paulo (GREA) were assessed for each trial. This service (GREA) is dedicated to the treatment of men who abuse or are dependent on alcohol and/or any other type of drug.

The exclusion criteria were (a) younger than 18 years of age or older than 60 years of age; (b) a current diagnosis of dependence or abuse of other substances except for nicotine; (c) patients with serious coexisting clinical diseases (e.s., inadequately controlled diabetes, cardiac failure, alcoholic cirrhosis); (d) previous treatment with any medication to treat alcoholism within six months of randomization; (e) concomitant psychiatric disorders that might require specific drug treatment; (f) inability to provide full informed consent; and $(g)$ a clinical history of mental retardation, as it reduced the accuracy of the information given.

For each study, all of the subjects provided written informed consent. They were informed about the objectives of each study, the nature of the treatment offered, and the profiles of the medications tested and that the medications they would receive would be chosen at random. All of the patients were assured about the confidentiality of the data and were informed that they were free to withdraw their consent and discontinue participation in the studies at any time without prejudice regarding their continued medical. care. All of the participants were encouraged to participate in Alcoholics Anonymous groups (AA), but this participation was not an obligatory condition of participating in these trials.

\section{Measurements}

In the first interview for each trial, after a full history and clinical examination, patients who fulfilled the inclusion criteria were evaluated. Socio-demographic data and lifetime drinking history, such as family antecedents of alcohol problems, daily intake of alcohol in grams, drinking onset age, age at onset of regular alcohol consumption, and problem drinking cnset age, were obtained in a standardized semi-structured interview commonly used in the ther apeutic setting of the interdisciplinary Group of Studies on Alcohol and Drugs of the Clinical Hospital of the Universidade de Sào Paulo in Brazil.

All of the patients were evaluated at the first interview with the short Alcohol Dependence Data (SADO), ${ }^{17}$ the Hamilton Depression Rating scale (HDRS), ${ }^{15}$ and the obsessive-compulsive Drinking scale (OCDS)." Blood was taken for a routine full blood count and for liver function tests.

A weighting scale was adopted to evaluate family alcoholism. The following grade was used: 0.5 points for firstdegree relatives and 0.25 points for second-degree relatives. A rigorous analysis of the incidence of alcohol dependence in first- and second-degree relatives was performed in line with another study.2 ${ }^{23}$

Additionally, the participants were questioned about their current average daily consumption of beer, spirits, and wine, with regard to the duration of use and the time of drinking (moming, aftemoon, or night). Beer preference drinkers were then defined as those who drank more beer than spirits or wine and accordingly for spirits and wine preference drinkers. For a more precise classification, we defined a particular type of alcoholic beverage as "predominant" if the consumption of that type of beverage accounted for two-thirds or more of the total of ethanol consumed during the last year. This classification was used in a previous study ${ }^{4}$

At each appointment, the participants were also asked about their participation in AA, and those subjected that attended AA at least once a week were considered to be adherent to this self-help group.

\section{Procedure}

All of the patients underwent a two-week detoxification period prior to initiating active medication or placebo. This detoxification period was conducted on an outpatient basis, and the patients were given medications, such as lorazepam 
up to $6 \mathrm{mg} /$ day and vitamin B1 $300 \mathrm{mg} /$ day, in cases of the manifesting of withdrawal symptoms. Laboratory exams, including liver function, were collected during this period. The patients manifested minimal to moderate withdrawal symptoms, which allowed them to be treated on an outpatient basis.

At each appointment, all of the patients received standardized and manual brief cognitive behavioral interventions. The overall goal of these interventions was to increase the subjects' ability to cope with high-risk situations that could precipitate relapses. The following topics were standardized and applied to each patient during treatment: management of negative mood, assertiveness, drink refusal skills, enhancement of social support networks and relapse prevention.

For each trial, all capsules were adequately manufactured to have identical appearances, thus avoiding any doubleblind violation.

Treatment retention was one of the cutcome measurements used in this joint study. We considered three reasons for dropping out of the trials: (a) "refuses to continue" (the patient affirmed that he wanted to stop that type of treatment and to try others, e.g., psychotherapy only); (b) "protocol violation" (the patient used other pharmacologic drugs during the studies); and (c) "lost to follow-up" (the patient gave up following the studies and did not manifest any desire to be treated differently). The patients who remained in treatment for all 12 weeks were considered completers. The patients who did not attend follow-ups were considered discontinuers.

\section{Data analysis}

The Kolmogorov-Smimov test was used to evaluate whether the variables were normally distributed. The following variables had to be square-root transformed: OCDS and HDRS mean levels and the quantity of ethanol per day. Direct logistic regression analysis (Wald's method) was performed to investigate associations between treatment outcome (completers versus discontinuers) and the following predictive variables measured at baseline: age, race, marital status, depressive symptoms (measured by HDRS), financial condition, marital status, time period since the regular drinking onset age, time period since the problem drinking onset age, preferred beverage, daity intake of alcohol before treatment, medication groups, AA attendance, severity of alcohol dependence (measured by SADD), and craving for alcohol (measured by OCDS). Given that all of the predictors were entered into the equation simultaneously (as long as tolerance was not violated), a predictor that was highly correlated with the outcome by itself might have shown little predictive capability in the presence of other highly correlated predictors. Therefore, we also computed the correlation matrix of the variables included in logistic regression analysis. Pearson's $r$, $\Phi$ and point-biserial correlation coefficients were used to indicate the relationships between two continuous variables, two categorical variables, and between one continuous variable and one categorical variable, respectively. The data were analyzed using SPSS statistics for windows, version 18.0 .

\section{Results}

Our sample was composed of 257 men, aged between 23 and 60 years of age (mean 43.76; SD 8.92). Approximately 56\% were married, $566 \%$ were white, $53 \%$ had not reached high school, and $65 \%$ were Christian. One hundred seventy-six (696) reported being smokers. Out of 257 participants, 136 (52.926) completed the studies. The baseline characteristics of this study population are displayed in Table 1.

As shown in Table 2, direct logistic regression analysis (v/ald's method) was performed on group status (completers and discontinuers) as an outcome and on the following predictors: medication groups and participation in $A A$ as treatmentrelated variables; and OCDS, SADD, and HDRS mean scores, age at the beginning of current treatment, time since the beginning of regular alcohol use, time since the problem drinking onset age, family alcoholism, preferred beverage, tobacco consumption, quantity of ethanol per day (before the current treatment), history of previous treatment for alcoholism, race, marital status, and financial situation were treated as variables possibly related to craving intensity. We chose this method despite the fact that some predictors could be strongly associated with other ones and, as a result, some of them could mask the effect of others. In this analysis, "age at the beginning of the current treatment", "participation in AA", "HDRS mean levels", and "beer preference drinkers" predicted treatment outcome. The model was statistically reliable, $\left(x^{2}=44.48,21 \mathrm{df}, \mathrm{p}<0.01\right)$. The variance in group membership accounted for was low, with Nagelkerke $R^{2}=$ 0.21 . The overall prediction success was $65.8 \%$. We checked the fit of our model using Hosmer and Lemeshow's test ( $x^{2}$ $=8.15,8 \mathrm{df}, \mathrm{p}=0.42$ ).

We also performed another direct logistic regression analysis involving only the variables that were significantly associated with treatment retention in the previous analysis. As shown in Table 3, "age at the beginning of the current treatment', 'participation in AQ', and 'HDPS mean levels' remained significantly associated with treatment retention. Conversely, 'beer preference' did not predict retention in this latter analysis. This model was statistically reliable, $\left(x^{2}=24.55,5 \mathrm{df}, \mathrm{p}<0.01\right)$. The variance in group membership accounted for was marginal, with Nagelkerke $R^{\prime}=0.12$. The overall prediction success was $65.4 \%$. The model fit was checked using Hosmer and Lemeshow's test ( $x^{2}=8.89,8 \mathrm{df}$, $p=0.35$ )

Table 4 shows correlation analyses involving variables measured at baseline. Although correlations inferior to 0.50 should be considered non-significant, we decided to show all correlations with p-values of less than 0.05. As shown in Table 4 , OCDS was negatively associated with age at the beginning of each trial and with the status of being married but was positively correlated with family alcoholism, severity of alcohol dependence, preferential consumption of spirits, and quantity of ethanol consumed before each trial.

\section{Discussion}

This study supports previous evidence that alcohol craving is positively correlated with family alcoholism, dependence severity, and quantity of ethanol consumed per day but negatively associated with the patient's age. in addition, alcohol craving was positively correlated with a preference 


\begin{tabular}{|c|c|}
\hline Charactertstic & $\begin{array}{l}\text { Putents } \\
(n=257)\end{array}$ \\
\hline Age, nean (SD) & $43.76(2.92)$ \\
\hline \multicolumn{2}{|l|}{ Raxe, nog } \\
\hline mite & $144(56,03)$ \\
\hline Bask & $33(12.84)$ \\
\hline Mtems race & $80(31.13)$ \\
\hline \multicolumn{2}{|l|}{ Marital stahs, $\mathrm{n}[\mathbf{X}]$} \\
\hline Married & $144(56.03)$ \\
\hline single & 4t (15.25) \\
\hline Separated/Widewer & $72,2800)$ \\
\hline Quantity of ethanol per day (in grana), a mean (SD) & 297.07 (178.41) \\
\hline 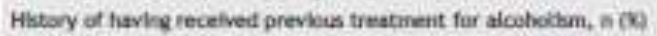 & $139(54.09)$ \\
\hline Merchily focame (lin RS, the Braztias conency), mean (SD) & $1,085,72.1002 .35)$ \\
\hline \multicolumn{2}{|l|}{ Peferied beveraes, aco } \\
\hline Spirtu & $183(71.20)$ \\
\hline Beer: & $71(27.69)$ \\
\hline Whe & $3(1.17)$ \\
\hline \multicolumn{2}{|l|}{ Medkation proups, in 109} \\
\hline Placebo & $106\{41.24\}$ \\
\hline Topirentate & $52(20.23)$ \\
\hline Hatuewone & $49(19.07)$ \\
\hline Ondassetron & $30\{19,4)$ \\
\hline Snobling, $n(0)$ & $177(69.87)$ \\
\hline OCDS, mean $(S D)$ & $47.99(12.19)$ \\
\hline SNDO, mean (SD) & $27, \pi(8.28)$ \\
\hline HORS, mesh (SD) & $9.90(6.38)$ \\
\hline Thine shice the regelar dinking atset ape (in yeen) & $-17.98(9.63)$ \\
\hline Tine since the protien dink hy orset we (ih years) & $11,19(9.12)$ \\
\hline Plamm GGT, U/L; (veference rasge 8.61), mean (SD) & $144.56(234.71)$ \\
\hline Pleme ALT, Un:; (nefereice range * 41 ), mean (SD) & $38.04(29.16)$ \\
\hline Plmma aST, U/L; (veleence range + 37), mean (SD) & $0.04(35.27)$ \\
\hline 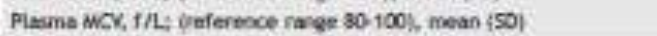 & $94 . \pi(7.22)$ \\
\hline
\end{tabular}

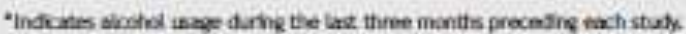

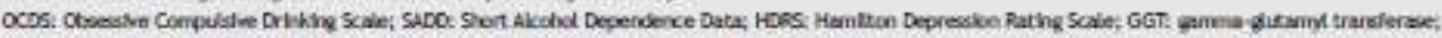

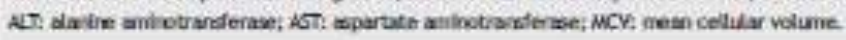

for spirits. increasing age, lower scores for depression, beer preference, and AA attendance predicted higher treatment retention. Contrary to our initial hypothesis, the variable 'craving' (measured by the ocDs at baseline) was not a strong predictive factor of treatment retention.

Other studies on patients with impulsive behaviors have already shown a decrease in impulsive and compulsive symptoms with increasing age, and this relationship also seems to be true among alcoholics. ${ }^{\text {In }}$ fact, a progressive reduction of daily alcohol intake, ${ }^{\text {th }}$ a decrease in mesolimbic neurotransmission, and changes in the hypothalamic-pituitary-adrenal (HPA $)^{22}$ and hypothalamic-pituitary-thyroid" axes have been hypothesized to be possible causal mechanisms for craving reduction with increasing age. Parallel to these studies, there has been some evidence that older age can predict better compliance with alcoholism treatment ${ }^{\text {st }}$

in our study, higher scores for depression predicted early discontinuation of treatment. Despite this finding. research has shown mixed results regarding the relationship between depression symptoms and treatment retention. ${ }^{\text {s }}$
Nevertheless, it is important to note that depression was positively correlated with longer drinking careers and more frequent histories of being previously treated for alcoholism. in fact, negative experiences with previous alcoholism treatment could have a negative impact on the future client's readiness to accept help for alcohol problems. The awareness that a previous experience was negative can powerfully change behavior and clinical outcomes. ${ }^{\text {th }}$ it is also important to stress that no participant was severely depressed or required specific treatment for depression in the present study, given that depression was an exclusion criterion for both trials.

Beer preference drinkers showed higher treatment retention than spirits and wine preference drinkers. This finding was already discussed in a previous study published by our group. "This finding was different from other studies that re. ported higher craving among beer preference drinkers, probably due to the greater volume intake of beer compared to other beverages. ${ }^{27}$ However, the influence of different types of beverages on craving and adherence to treatment can 
Table 2 Effects of clinical and psychosocial variables at baseline on treatment retention (direct logistic regression)

\begin{tabular}{|c|c|c|c|c|c|c|}
\hline Varlables & SE & Wald & at & p & OR & Ci. $195 \%$ \\
\hline he & 0.02 & 4.96 & $t$ & $0.012^{\circ}$ & 1.05 & $1.01-1.09$ \\
\hline \multicolumn{7}{|l|}{ Roce: } \\
\hline White freference\} & 0.45 & 0.11 & 1 & 0.74 & 1.16 & 0.48 .2 .81 \\
\hline atack & 0.33 & 2.55 & 1 & 0.11 & 0.5 & $0.31-1.13$ \\
\hline \multicolumn{7}{|l|}{ Whed races } \\
\hline \multicolumn{7}{|l|}{ Mertul staris } \\
\hline \multicolumn{7}{|l|}{ Married (irlerencin) } \\
\hline Single & 0.42 & 1.01 & 1 & 0.39 & 1.52 & 0.67 .3 .45 \\
\hline Separated/Widowned & 0.34 & 0.89 & 1 & 0.34 & 0.73 & $0.37-1.45$ \\
\hline Quantity of ecthand per day (in grita) & 0,0 & Q.14 & $t$ & 0.71 & $=0.9$ & $0.99-1.01$ \\
\hline Prevbss treatuents for abohothan & 0.29 & 0.53 & 1 & 0.72 & 1.11 & $0.63 \cdot 1.95$ \\
\hline Monthly lincente & $=0.01$ & 3.62 & 1 & 0.06 & $=0.99$ & $0.991 .0 t$ \\
\hline \multicolumn{7}{|l|}{ Prefurred teverape } \\
\hline \multicolumn{7}{|l|}{ Splvits \{reference\}: } \\
\hline Beer & 0.33 & 4.07 & $t$ & $0,04^{2}$ & 1.95 & $1.02 \cdot 3.75$ \\
\hline Whe & 1.72 & 0.72 & 1 & 0.39 & 3.07 & $0.23 \cdot 41.04$ \\
\hline \multicolumn{7}{|l|}{ Medication groups: } \\
\hline \multicolumn{7}{|l|}{ Pixcetoo (iveference) } \\
\hline Oxdassetron: & 0.40 & 2.85 & $t$ & 0.09 & 1.95 & $0.90-430$ \\
\hline Naltrexone & 0.40 & 2.20 & 1 & 0.14 & 1.92 & $0.92 .3 . \% 9$ \\
\hline Poplanate & 0.40 & 1.55 & 1 & 0.21 & 1.65 & $0.75 \cdot 3.65$ \\
\hline Senoiding & 0.32 & 0.30 & 1 & 0.58 & 1.19 & 0.642 .23 \\
\hline ocos & 0.02 & .0 .01 & $t$ & 0.95 & 0.99 & $0.97 \cdot 1.03$ \\
\hline SADO & 0.02 & +0.01 & 1 & 0.94 & 1.01 & $0.95-1.05$ \\
\hline Hors & 0.09 & 5.56 & 1 & $0.02 *$ & 0.95 & $0.900 .9 \%$ \\
\hline Yeas shce the repuia ifrinding orset aye & 0.03 & 1.27 & $t$ & 0.26 & t.03 & $0.98+1.08$ \\
\hline Yeas shce the probiem drinking enset ane & 0.02 & 2.44 & $t$ & 0.12 & 0.95 & 0.92 .1 .01 \\
\hline Ah Attendorce & 0.49 & 5.70 & 1 & $0.2^{*}$ & 3.12 & 1.2377 .97 \\
\hline
\end{tabular}

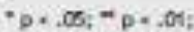

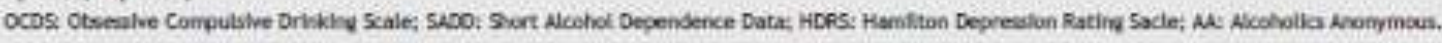

Table 3 Direct logistic regression model including only the variables that were significantly associated with treatment retention in Table 2

\begin{tabular}{|c|c|c|c|c|c|c|}
\hline Vartables & SE & Waid & dif & p & OR & $c l(95 \%)$ \\
\hline \multicolumn{7}{|c|}{ Preferced beverze } \\
\hline Beer & 0.30 & 3.52 & $t$ & 0.06 & 1.75 & $0.98 \cdot 3.15$ \\
\hline Wine: & 1.26 & 0.17 & 1 & 0.68 & 1.68 & $0,1418.99$ \\
\hline Hors & 0.08 & 4.34 & 1 & $0.03^{*}$ & 0.96 & 0.920 .99 \\
\hline
\end{tabular}

$* 0 \times 0.00 ; * p=0.01$;

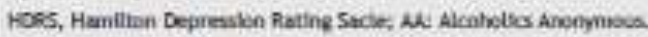

be a byproduct of several confounding variables, such as cultural and socioeconomic factors. Although greater volume intake among beer drinkers is related to craving intensity, mainly due to its influence on volume-regulating peptides, spirits drinkers can consume greater quantities of ethanol per day than beer drinkers. Alcohol craving is also associated with the daily amount of ethanol consumed and with the severity of alcohol dependence. "In our study, the correlations between these two variables (alcoholism severity and quantity of ethanol) in spirits drinkers were positive and significant.
Participation in AA was significantly correlated with retention in treatment. To date, there has been no conclusive scientific evidence that participation in AA keeps patients in treatment longer. it in general, one of the difficulties in evaluating the effectiveness of participation in $A A$ is the self-selection bias of those who participate. Because individuals self-select themselves for participation in AA, otherwise known as selection bias, it is not clear whether there are personality or motivational factors related to the decision to join this self-help group. Some authors have reported that alcoholics who attend $A A$ are typically more 
Table 4 Correlation matrix of the variables included in the multivariate analyses (Pearson's $r$, Phi, point-biserial)

\begin{tabular}{|c|c|c|c|c|c|c|c|c|c|c|c|c|c|c|}
\hline Wriables & (7) & 12) & (3) & $\{4\}$ & (5) & (b) & $(n)$ & (3) & (9) & (10) & (11) & (12) & (13) & (14) \\
\hline (1) $0 \mathrm{cos}$ & 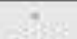 & & & & & & & & & & & & & \\
\hline Qike at the texinhing of exch trial & 8.27 & r & & & & & & & & & & & & \\
\hline (3) Race (atitie) & ra & is & . & & & & & & & & & & & \\
\hline (4) Famfily wicothellain & $0.20^{n}$ & is & $\approx$ & s & & & & & & & & & & \\
\hline (5) SADO & $0.70^{-1}$ & $0.22 *$ & $\approx$ & $0.23^{* *}$ & $=$ & & & & & & & & & \\
\hline (6) Smoking & a & $\mathbf{m}$ & 6.13 & $\mathrm{a}$ & is & - & & & & & & & & \\
\hline $\begin{array}{l}\text { (7) Time stroe the regular driking } \\
\text { onset age (in years) }\end{array}$ & is & $0.60^{2}$ & a & e.14 & es: & es & + & & & & & & & \\
\hline $\begin{array}{l}\text { (3) Time shoce the problem ditnbing } \\
\text { arset aje (in years) }\end{array}$ & es & $0.40^{20}$ & a & is & is & es & 0.75 & - & & & & & & \\
\hline (9) Preferrod beverape ispinisi) & $0.10^{*}$ & es & \# & 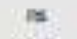 & $0.23^{*}$ & $\approx$ & is & as & ? & & & & & \\
\hline (10) Quantity of ethaibl per day & a.3T & Q.190 & $a$ & e.15 & $0.35^{\prime \prime}$ & $e$ & $0.18^{\circ \prime}$ & 0.16 & $0.15^{\circ}$ & s. & & & & \\
\hline (11) HDRS & en & es & 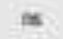 & es & es & es & e.18 & a.14 & es & ms & * & & & \\
\hline (12) Mareal stasus inaried) & $6.27^{\circ}$ & $0.19^{\prime \prime}$ & 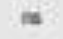 & 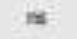 & $0.26^{*}$ & es & $0.14^{*}$ & is & $\mathrm{ms}$ & 0.15 & in & ? & & \\
\hline (13) Monthily nceme & est & 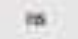 & $\approx$ & $\mathbf{m}$ & $0.16^{2+}$ & $\mathrm{es}$ & es & $\approx$ & 0.16 & ins & 0.15 & is & $=$ & \\
\hline (14) Prevlous treatments for scoholbm & in & $\mathrm{s}$ & $=$ & $\mathrm{a}$ & is & es & is & is & $\mathrm{As}$ & ns & $0.36^{\prime \prime}$ & is & is & + \\
\hline
\end{tabular}

sociable and affiliative, more guilty over past behavior, physically healthier, and more socially stable." Conversely, other authors have affirmed that attendance at AA is more common among racial and ethnic minority groups, those with lower incomes, and those with unstable employment. ${ }^{2 t}$ Although these generalizations can be problematic and doubtful, some characteristics attributed to AA participants have a certain level of acceptability, given the inherent characteristics of self-help groups. In fact, participating in AA was not an obligatory condition to partake in any of our trials, despite the encouragement given by researchers. This fact could mean that the most motivated and affiliative patients decide to participate in AA with the goal of improving their coping skitls and changing their friendship networks. "Other authors suggest that success in AA is associated with frequent and continued attendance and not with motivation per se.

Active medications did not influence treatment retention in the present study. Other studies have already shown that treatment with opioid antagonists, ${ }^{34}$ topiramate, ${ }^{25}$ and ondansetron, alone or in combination with naltrexone, $x, 1$. was not associated with increased retention in treatment, compared with placebo. Furthermore, even combinations of two medications for alcoholism have not shown effects on retention in treatment compared with individual pharmacotherapies alone.

Although craving is an important factor to be measured and investigated at baseline and during treatment, our study was not able to show that it is a strong predictive factor of retention, at least when craving intensity was computed at baseline only. in reality, craving is not a stable state but rather depends on other variables that can be modified during treatment, such as mood, stress, substanceusing status, environmental cues, etc. Nevertheless, other variables significantly correlated with craving, such as age and preferred beverage, were significantly associated with treatment retention.
Despite the heterogeneity of our clients, many therapeutic programs offer only a single type of treatment. With this "one size fits all" model, variations in retention have been commonly attributed to client factors or characteristics. Although this belief might be true to some extent, health services should broaden the scope of services offered to meet the heterogeneous needs of clients and identify treatment practices and therapies that improve retention. information about patients' characteristics linked to noncompliance or dropout should be used to render treatment programs more responsive and attractive, combining phamacologic agents with more intensive and diversified psychosocial interventions. Certain approaches, such as compliance enhancement therapy and motivational interviews, can be effective options when combining adjunctive interventions for randomized clinical trials. ${ }^{21}$ Strategies to improve motivation are of paramount importance in different treatment programs, and they will be taken into account in future research by our group.

There were several weaknesses in this present study, including the following:

(1) There were no other psychotherapeutic procedures associated with the pharmacological treatments, which could have increased the retention of the patients.

(2) The number of dropouts was high in both trials, probably as a result of their designs, which allowed patients to follow the standard community-based programs of treatment, without norms to increase patient retention. Although this approach to trial design, which allows for nomal life events to influence trial outcomes, probably enhances externak validity, it can lead to considerable difficulties in interpreting data, such as motives for relapse and premature discontinuation of follow-up. 
(3) Additionally, our service is tertiary, and many severe cases are referred to it. This fact can be verified by the enomnous quantity of ethanol consumed by our subjects. It is difficult to generalize our findings to a less severely alcoholic population.

(4) Our research did not include women. some studies have shown that sex differences exert different influences on retention treatment and craving."

(5) The dosage of ondansetron tested (16 mg/day) was higher than the dosages usually investigated by other studies. This fact might have compromised this study's comparability to other studies.

(6) Our trials timited the examination of AA participation to the frequency and regularity of meeting attendance, which failed to capture the breadth of involvement in the program.

(7) Although $O C D S$ was measured at three time points (at baseline, at the sixth week, and at the twelfth week) in each double-blind study, we coly evaluated the effect on treatment retention of OCDS measured at baseline, due to some of the participants having discontinued the treatment before the sixth week. In this study, our aim was to investigate treatment retention in general, without taking into account the different times at which dropouts occurred.

\section{Disclosures}

Jobe Maria Cerrea Fitho, MO

Emplayent: Depertinent of Paychlaty of the Universildade de Slo Pauie,

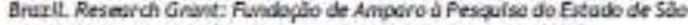
foulo of The Stete of Slo Pacio firseardh Foundotion - FAPESP?

Danille Antonlo Baltieri, 10, Pho

Employment: Depcrtment of Pypchiaery of the Unlversidade de sab Paule; Department of Pyychiatry of Facuidade de Medicha do ABC. Santo Anant, SP, Brazkl.

This study has recelvend grants from RAPESP Findapalo de Anquaro d Fesquise de Estode de Salo Pasle. The Stote of Sáb Paulo Researdh Foundationi).

- Modest

- Sipniffaunt

- Significant, Amounts given to the outher's irstitution or to a collegue for reseurch ks whilh the auther has particlpetion, net directly to the owthor.

\section{References}

1. Flannery BA, Poole SA, Gallop RJ, Volpioelli 3R. Alochol oraving predicts drinking during treatment: an analysis of three assessment instruments. J Stud Aloohol. 2003;64(t):120-6.

2. Graff FS, Morgan TJ, Epstein EE, et al. Engagement and retention in outpatient alcoholiem treatment for women. Am JAddiot. 2009; 18(4):277-88.

3. Hintzen AK, Cramer J, Karagulle D, et al. Doez aloohol oraving decreace with increacing age? Reaults from a coccs-sectional study. J Stud Aloohol Drugs. 2011;72(1):158-62.

4. Baltieri DA, Daro FR, Ribeiro PL, De Andrade AG. The role of alooholio beverage preferenoe in the severity of alochol dependence and adherence to the treatment. Aloohol $2009 ; 43(3): 185-95$.

5. Gordon SM, Sterting R, Siathowski C, Raively K, Weinatein S. Hill PC. Inpatient desire to drink a a predictor of relapse to aloohol use following treatment. Am J Addiot. 2006;15(3):242.5.

6. MoKay JR. Negative Mood, Craving, and Aloohol Relapse Can Treatment Interrupt the Procezz? Curr Psyohiatry Rep: $2011 ; 13(6): 431-3$.
7. Sinha R, Fox HC, Hong KA, Bergquist K, Bhagwagar Z, Siedlar WM. Enhanoed negative emotion and alcohol craving, and altered phyciological responces following streez and oue expocure in aloohol dependent individualt. Neuropayohopharmacology. 2007; 34(5):1198-208.

8. Hillemacher $T$, Bayerlein $K$, Witheim J, et al. Volume intake and craving in aloohol withdrawal. Aloohol Aloohol. 2006;41(1):61-5.

9. Maloolm R, Herron JE, Anton RF, Roberte J, Moore J. Reourrent detoxifioation may elevate aloohol craving a meacured by the Obeessive Compulaive Drinking roale. Aloohol 2000;20(2):181-5.

10. Baltieri DA, Daro FR, Ribeiro PL, Andrade AG. Effeots of topiramate or naltrexone on tobacoo use among male alooholdependent outpatientz. Drug Alcohol Depend. 2009;105 (1-2): $33-41$,

11. Sinha R, OMalley SS. Craving for alcohol: findings from the clinio and the laboratory. Aloohol Aloohol 1999;34(2):223-90.

12. Garbutt JC. The state of pharmacotherapy for the treatment of aloohol dependenoe. J Subst Abuze Treat. 2009;36(1):515-23.

13. Johnoon BA, Roache JD, Ait-Daoud N, Zanoa NA, Velazquez ML Ondancetron reduces the craving of biologically predicpoced alooholioz. Psychopharmaoology. 2002;160(4); $406-13$.

14. Baltieri DA, Daro FR, Ribeiro PL, de Andrade AG. Comparing topiramate with naltrexone in the treatment of aloohol dependenoe. Addiotion. 2008; 103(12):2035-44.

15. Gocsop M, Marsden J. Stewart D, Rolfe A. Treatment retention and 1 year outcomes for residential programmes in England. Drug Aloohol Depend. 1999;57 (2):29-98.

16. National Treatment Agenoy for Subatance Misuse, Buciness Plan. London: National. Treatment Agenoy for Substance Miause; 2006.

17. Raiztriok D, Dunbar G, Davidson R. Development of a questionnaire to mexeure aloohol dependence. Br $J$ Addict. $1983 ; 78(1)-89-95$.

18. Hamitton M A rating scale for depression. J Neurol Neurceurg Psychiatry 1960;23:56-62.

19. Anton RF, Moak DH, Latham P. The Obeessive Compulsive Drinking Scale: a self-rated inetrument for the quantifioation of thoughte about alcohol and drinking behavior. Aloohol Clin Eup Rez. 1995:19(1):92-9.

20. Haueer J, Rybahoweki J. Three olueters of male alcoholics. Drus Aloohol Depend. 1997;48(3):243-50.

21. Thang $Y$, Guo $X$, Saitz R, et al. Seoular trends in alcohol concumption over 50 years: the Framingham Study. Am J Med. 2008; $121(8): 695-701$.

22. Munro CA, Oswrald LM, Weerts EM, MoCaul ME, Wand GS. Hormone responces to social stress in abctinent alooholdependent subjeots and social drinkers with no history of aloohol dependenoe. Aloohol Clin Exp Res. 2005;29(7):1133-8.

23. Lesgio L. Ferrulli A. Cardone 5, et al. Relationship between the hypothal amio-pituritary-thyroid avis and aloohol oraving in aloohol-dependent patients: a longitudinal study. Aloohol Clin Exp Rez. 2008;32(12):2047-53.

24. Athinson RM, Misra S, Ryan SC, Turner JA. Referral pathe, patient profiles and treatment acherenoe of older alooholio men. J Subat Abuse Treat. 2003;25(1):29-35.

25. Charney DA, Paraherakis AA, Negrete JC, Gill KJ. The impact of depression on the outoome of addictions treatment. J Subat Abure Treat. 1996; 15(2):123-90.

26. Porro CA. Open your mind to placebo oonditioning. Pain. $2009 ; 145(1-2): 2-3$.

27. Hillemacher $\tau$, Bayerlein $K$, Reulbach U, et al. Influence of beer, wine and spirite oonsumption on craving. Addiot Biol. $2005 ; 10[2]$; $181-6$.

28. Ferri M, Amato L Davoli M. Alooholios Anonymous and other 12 step progranmes for alochol dependenoe. Cochrane Databace Syst Pev. 2006;3:C0005032. 
29. Tonigan JS, Tosoova R, BSiller WR, Meta-analypis of the literature on Alooholice Anonymous: sample and study characteristic: moderate findings. J Stud Alcohol. 1996;57(1):65-72

90. Emrick CD. Alcoholics Anonymous: affiliation prooesses and effeotiveness as treatment. Alcohol Clin Exp Res. $1987 ; 11(5)=416-23$.

31. Humphreys K, Kaskutas LA, Weisner C. The relationship of pre-treatment Alooholice Anonymoue affiliation with problem severity, social resouroes and treatment history. Drug Aloohol Depend. 1996;49(2):123-31.

32. Humphreys K, Mankowaki $E$, Moos RH, Finney JW. Do enhanoed friendahip networks and active ooping mediate the effect of self-help groups on subatance abuse? Ann Behav Med. $1999 ; 21(1)=54-60$.

33. Fiorentine R, Hillhoure MP. Exploring the additive effeots of drug mizec treatment and Twelve-Steo involvement: does Twelve Step ideology matter? Subst Use Nlisuse. 2000;35(3):367-97

34. Heinala P. Alho $H$, Krianmaa K, Lonnqvist J, Kuoppasalmi K. Sinolair JD. Targeted use of naltrexone without prior detoxification in the treatment of alcohol dependence: a faotorial double-blind, placebo-oontrolled trial. J Clin Psychopharmacol. 2001(3);21:287-92.

35. Johnoon BA, Rocenthal N, Capece JA, et al. Topiramate for treating aloohol dependenoe: a randomized controlled trial. JAML. 2007;298(14):1641-51.
36. Johnson BA, Roache JD, Javors MA, et al. Ondaneetron for reduotion of drinking among biologioally predisposed alcoholio patients: A randomized oontrolled trial. JAMA. 2000;284(8): $963-71$.

37. Ait-Daoud N, Johnson BA, Javors M, Roache JD, Zanoz NA Combining ondansetron and nattrexone treats biological alooholics: corroboration of self-reported drinking by serum carbohydrate deficient transferrin, a bionarker. Aloohol $\mathrm{Cl}$ in Exp Res. 2001;25(6):847-9.

38. Anton RF, OMalley 5S, Ciraulo DA, et at. Combined pharmacotherapies and behavioral interventions for aloohol dependence: the CONBDE etudy: a randomized oontrolled trial. JAML. 2006;295(17);2003-17.

39. Heffner JL. Tran GQ Johnson CS, et al. Combining motivational interviewing with compliance enhanoement therapy (MCET): development and preliminary evaluation of a new, manual-guided psychosocial adjunot to aloohol-dependenoe pharmaootherapy J Stud Aloohol Drugg. 2010,71(1):61-70.

40. Greenfield SF, Brooks AJ, Gordon S14, et al. Substanoe abuse treatment entry, retention, and outcome in women: a review of the literature. Drug Alochol Depend. 2007;86(1):1-21. 


\title{
Anexo $\mathrm{O}$ (Artigo publicado na Addictive Behaviors)
}

madictie Bethisors 39 (2013) 2044-205:

Contonts lise avalablo at SolVorso Se bnoo Diroct

Addictive Behaviors

\section{A pilot study of full-dose ondansetron to treat heavy-drinking men withdrawing from alcohol in Brazil}

Joăo Maria Corrêa Filho ${ }^{2}$, Danilo Antonio Baltieri ${ }^{\text {, h. }}$ *

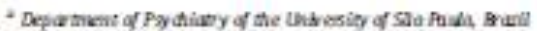

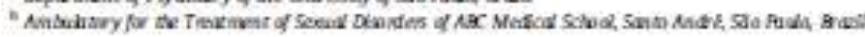

\section{H IGHLICHTS}

- Ondansegon has emerged $x$ a promiang medicason for the treatment of alcoholism.

- Ondancearon had a frorable sideeffect profile.

- Ar ondansetron dose of $16 \mathrm{mg}$ day was not effective $\mathrm{m}$ treat alcoholics.

- The optimal dosage to trear alooholism hax yet os be determined.

ARTICLE INFO

\section{Kirmonit:}

Ontecteron

Acobd dependince

Raninacodesapy

Clicicitis

\begin{abstract}
A BSTRACT
Ondansetron has emerzed as a pnmicing medicabon for the trea enent of almhol dependena, mainly anong earty-onset alooholics. This research primarily amed to wabate the efficacy and safety of ondansernon at a $16 \mathrm{mg} / \mathrm{d} y$ dosage in treat aloohol dependent outprients. A double blind, plwebo-controlled, 12 werk study was carried out at the Univessty of $\$ 30$ Paib, Bnizil the atal sample comprised 102 men, 18 -60 years of

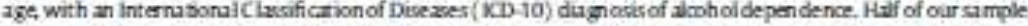
discomtinard the trexment and the main outcome mezures (proporbon of abost nent days and proporticn of havy drinking dyss) were anshysed using the treatment adherents as well as with an imputed sample the main frctors aswoduzd with trestment rezenbon were older age and smoking statuk. Although there were no s gnificant difierences between the main outcome measures of both medication groups in the adherenta. ondansetnn demonstrated a stigtt but significant superiority over the placebo regarding the proportian o heavy drinking drys in the imputed smple (7.8x versus 11.7x, respectivdy). it appears thr the optimal docage to trext aloholism has yet os be decermined. Further ondansetron may only be useful in treasing some types $d$ alonholics Ondanseson was well tolerated and no serious adverse evens were regízed
\end{abstract}

Q 2013 Flevier ltd. Al rights resarved.

\section{Introduction}

To date, the US Food and Drug Administration has apptoved the fol. lowing medications for zkohol dependence: disulfiram acamprosite, and oral/extended-release naltreocote. Several other medications are under active study, such as ondansetron, topiramate, backafen and some antidepressants fCastro s Balferi, 2004; Garturi. KampovPolevoy, Gallop, Kalla-juhl, \& Famery, 2010; Mann \& Hermann. 2010; flosiner et aL, 2010), of these non-approved drugs, andanseroti has emerged as a promising medication for the treatment of akohol dependence, mainly among earfy-onset aicoholics (johnson, Rouche, Ait-Daoud, Zanca, \& Velaques, 2002; jolunson et al, 2000; Krarzler. Pieniari-Lugha, Feinn, \&Hernandez-Avil2, 2003).

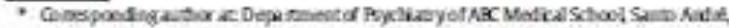

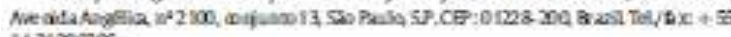
$113120 a 96$.
}

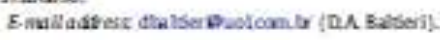

Studies frave shown that the 5- $\mathrm{HT}_{\mathrm{T}}$ antagonist ondansetron reduces akohol-induced positive subjective eflects and alcohol preference (Dy! B. Kastouski, 1995: Marride et aL, 2004; Myrick Antan, Li, Menderson. Randall \& Voronin, 2008) _ In fact. 5-HT receptars aredensely distributed in the mesocor bicolimbic neurond terminals, regulating dopamine relese. Ondansetron biacls the peripheral and central $5-\mathrm{HT}_{3}$ receptars. and throughcentral antagonism it inhibis dopamine-release cell firins in the nudeus accumbens (SWift, Davidson, Whelihan, \& Kumetsov. 1996; Ye, Ponnudurai, \& Schuefer, 2001). In addition, ondansetran appears to have activity at the $5-\mathrm{HT}_{\mathrm{v}}, 5-\mathrm{HT}_{\mathrm{in}}, \mathrm{\alpha}-1$-adtenergic, and H-opioid receptars: (MaNuil oy, 2007)

Differing fr om stuxties that hye evaluated ondansetron eflicacy at dasages ranging from 12 to 24 mg daily for the treatment of ather paydriatric and neur ological disturthanos, stidh as depression in butimic patients (Faris et al, 2006), hallucinations and delusions in Parkinson's psychosis (Friedberg, Zoldan, Weizman, \& Melamed. 1998; Zoldin. Friedtherg, Livneh, \& Melamed, 1995) and tardive dys. kinesia in schimphrenic patients (Sirota, Mas heve, Shabray, Giladil \& 
Korczyn 2000), akoholism clinical trials have tested relatively low dases of andarsetron ( between 1 and $16 \mu g / \mathrm{kg}$ bid). Notwithstanding these law dorses used b treat alcoholism, one study has investiga ted the efficacy of a higher dose of this medication (up to $0,45 \mathrm{mg} / \mathrm{kg}$ tid) for smoking cesstion (Cropp \& Cora-Harper, 1995).

Considering the high safety and law taxiciry of andansetron in the treatment of different medical problems (Fabi et al, 2008; Salvixciet al, 2011; Ye et al, 2001), as weil as its presumed efficacy at doses above 12 mg per diy for other neuropsycliatric disorders, we dedided to test this drug among akohol-dependent outpatients at a dosage uswally prescribed to manage chemotherapy-induced nassea and vomiting, in thesame way as has been car ried out instialies on its eflicacy far treating other neuropsychiatric illnesses.

\section{Method}

\section{Design}

A randomized, doible-Hilind, placko-onntrolled clirical trial was performed $t$ determine the efflcacy of ondansetron in reducing drinking, promoting akcohol abstimence, and decressing cravings in alcohol-dependent individiuls. The treatment lasted 12 weels.

\section{Partidpans}

Male patients, aged $18-60$ years, and with an Internitionvl Gassifi. cxian of Dtseaves (KD-10; Warld Health Organizathn, 1992) divgnosis of alcohol dependence that enrolled as outpatients in the Assistance Secbr of the Interdisciplinary Group of Studies on Akohol and Dnuzs at the Univer sity of Sio Paulo (PROGREA), Drazil, were assessed fot trial This service (PROCREA) is exclusively dedicated to the treatment of men with alcoholand br any othertypeof drug aluse or dependenos.

Buclusion criteria were: ( $a$ ) $<18$ years or $\geqslant 60$ years of age; (b) dintcally sigrificant medical disease that might have intar fered with the evaluation of the study medication, of presence of a safery. concern (eg. cirhosis, kadney impirment, unstable hypertenion, diabetes mellitus, seizure disorder, car diac falure); (c) pasitive screen for other types of drug abuse exaep nimtine, verified through the application of the DAST (Drug Abuse Soreening Test, when culf-off $\geq 5$ ) (Skinner, 1982); (d) clinically significant psychiatric illness, including any prychotic disorder, tipoilar disorder, or severe depression as evaluated with the Mini Internstiond Neuropsychiatr ic interview (MIN versian 50) (Amarim, 2000); (e) previous treatment with ondansetron within 6 months of r and amization; (f) current use of disulfiram nal trexane or acamprosate; $(\mathrm{g}$ ) cur rent use of any psychotropic medication including antidepressants, mood sta hilizers, antipiychotics, anociolytics stimuLuts or hypnotics; (b) insility to give full infarmed cansent and (i) clinical history of mental retandation, asit would reduce the accuracy of the infarmation provided.

All subjects provided written informed cansent, were assured of the confidentiality of the $\mathrm{dab}$. and were informed that they were free to withdr aw their consent and discontinue participation in the study at any time without prejudice to their cantinued medical care. The Eniks Committee of the Cinical Haspital of the Univer sity of 5io Paub, approved this stuxly.

\section{Measive:}

Before initiating the double-bind treatment, all patients were evaluated with the revised Ginical Institute Withdrawal Assessment for Alabiol (aWA-Ar; Sullivan, Sykara, Schneiderman, Naranja, \& Sellers; 1989), the Short Alcohol Dependence Duta (SADD; Raistrick, Duntart, g Davidsan, 1983) and the Alcohol Use Identification Test (AUDT; Bohn Bahor, \& Krander, 1995), and underwent 2-week detcoification period This pre-study phase was conducted on an outpatient busis and the patients were given medicaions with reference to their CIWA-Ar scires such as up to 6 mgiday larazepam and $300 \mathrm{mg} / \mathrm{day}$ vitamin $\mathrm{B} 1$, in case they manifested withdrawal symptams. The putients included in this study manifested minimal to maderate withdrawalsymptoms, which allowed them to be treated an an ourpatient basis. Mean cellular valume (MCV) Latorabry tests to screen for liver disorders - $\gamma$-glutamyl-transpeptidase (CGT), espartate aninotrarsferase (AST), chrine aminotrarsferase (ALT), bilirutin and prothrombin time - and a clinical evaluation of heart function - electrocardiography (ECG), observatian, papation and auscultatian - were performed in this pre-study pluse.

Before randomization, subjects were distinguis hed as being either early (EOA) or late onset akoholics (LOA) by applying a single question - "At what age did drinising become a probilen for you? = EOA had an age of onset of almholism between the ages of $13-25$ years, and LOA had an age of onse of aionholism greater than 25 years of age.

Sthsequenty, following a breathulyar (that had to be $0.00 \mathrm{~s}$ ) and a full history and dirical examination patents who fulfilled the indusion criteria initiand thestudy.Socio-demographicdab and lifetime drinking history, such as daily intake of akmhal in grams, drink ing onset age, problem drinking onset age, and durabon of problem dr inkins (in years) were ob bined in a standarfized, semi-s truchured interview commonly wed in the therapeatic setting of the PROGRE.A. Alcohol consumptian was aressed at euch visit using the timelire follow -badk method (Annis et al, 1996). The Hamiltan Depression Rating Scale (1DRS; Haniltan, 1960), and the Otressive-Compulsive Driniking Scale (OCDS. AntanMosk, \& Latham, 1995) were applied at weels 1.6 and 12 of the study. After week 1, the UKU Side Ellect Raxing Sale (UKU; Linigjoerde, Ahllars, Bech Dencker \& Elgen 1987) was applied at each visit.

Potients were assessed 12 times during the study Major var iables recorded at each visit induded the patients' seif-reported quentity. frequency of alcohol onsumption, and drug side effects for afl participants alstinenos from akohol was evaluated based on the parient's self-report at each appointment, by measuring alonol abuse lepatic indices - GGT, AI.T, AST, and MCV at week 6 and 12 and by interviewing a fimily member at euch patient's appointment Cardiac exam (observation, pelpition and auscultation), and alstinenos symptams of all participants were evaluated at each appointment. Patients with a history of substance-related disorders in treatment programs an develop an understanding of the detection parameters for alcubol by urine or breath testing, and some aftempt to circumvent manitoring by timing their drinking it is known that some patients drink during weekends or other times when testing is unlikely to ocrur, Therefore, we preferr ed evaluating the levels of alcolol abuse hepatic indices actoss the stuxly, verifying if these indices were decreasing, and investigating if changes in these measures were in line with patients' self-report.

In additian, medicatian compliance was evaluated at each appointment by asking patients the following questions: (a) Have you already forgotten to take your medicsions? (b) Are you sometimes negledful in regard to your medidne time? (c) Do you silip your medicine time when you are feeling vell? (d) When you feel bad (sick, feeling side effects) due to the medidine, do you skip in? Those that answered in the negative to the 4 questions were considered allerent to this study. Furdhermore, the cosules in the returned pockages wer e counted (capsules taken subtracted from capsules given) at every a ppointment. We coded an individual as adherent if they took 80\% or more of the total prescrilned pills on a partiailar week.

\section{Outcame citeri.}

The primury autcame messures were:

a) Peroe ntage of abstinent days (XARS);

b) Percentage of heavy drinking days ( 2 HDD; a heavy drinking day was defined as the consimption of mare than $70 \mathrm{~g}$ ethanol of more than 5 standard drinking units). 
The secondary outonme measures were:

a) Mean drinks per day ( 1 drink $=14$ g of ethanol);

b) Subjective reports of side effects;

c) Ressans for dropouts;

d) Factors assodated with discontinuation of the treatment.

Patients who did not attend follow-up, who did not take sce or more of the total prescribed pills an a particular week, and whase cutcarne Were uninown were considered to have dropped out of the research. Three reasons for dropping out fram this research were categoriad (a) "refuse to motinue" (the potient Afirmet tha he wanted to stop that type of treatment and to try others, eg, psychotherapy only) (b) "provenil vialaboir" (the parient used ather pharmacnlogic drugs during the study and/or stopped taking the study medication); and (c) Tost to follow-up" (the patient gave up following the study and did not manilest any desire to be treatad dillerently).

In addition, the prindple of this double-tilind procedure was verified by obtaining a prediction from each patient with relesence to his allocated treatment and a prediction fram the researcher (active medication or placebo).

\section{Procechure}

Between 2003 and 2010, 172 patients were screened Ass shown in Fig. 1, 49 declined to participate in this study and 21 were excluded because of coexisting disexses, leaving a sample of 102 individuats. All theselected patients Were encruraged to participate in AA groups, but this wes not an obligatory condition of participation in this study. The sume doctar who collected the duta car ried out the dinical eval. Iations, and this fact could havegenerated issues regar ding the integ rity of thissturly. Thus, we also tested this hypothesis

The partidpants were randamly divided into 2 groups, through computer-gene rated random numbers.All partidpans were instructed to take 1 capsitle in the moming and one at right. Once a week, the patients recelved an envelope with 2 padkges containing 7 capsules. One padkase was designated for morning dosing and the other for night-time.

One group received 2 capsules euch containing $8 \mathrm{mg}$ ond ansetron. and the other group received 2 placebo capsules every day during the 12 weels. All capsules in eadh treatment group were identical in appearance and size and had been manufactured and distributed by the Pharmacy Secter at the Pyydiatric Institute of the Clinical Hos pitat

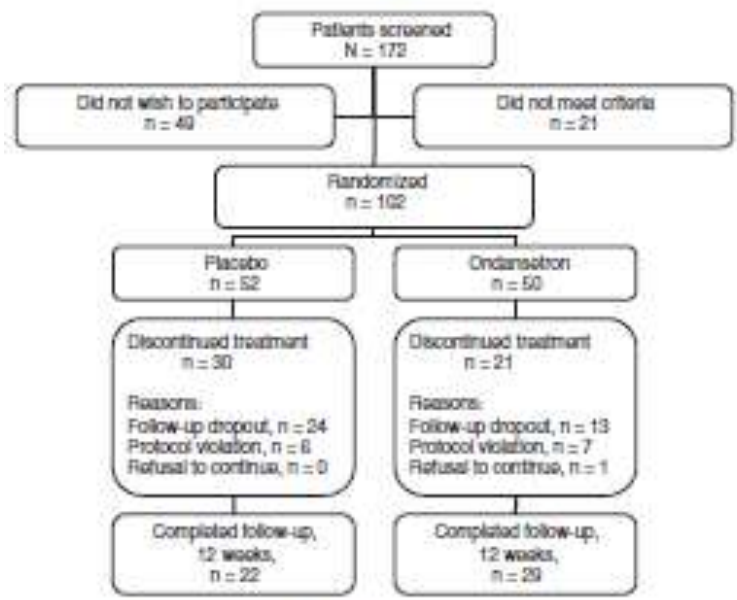

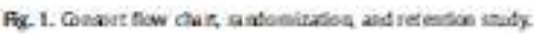

af Sto Pado University. This study was not sponsored by a pharmaceutical campary.

At exch appointment, all patients received standardized brief cos. nitive behwioral inferventions. The overall goal of these interven tions was to increase the person's ahility to cope with high-fisk situations that could precipitate relapser. The driniking behavior at the patients was reviewed in each visit, and the medication compliance and motivation for dhange were improved using motivational interviewing strategies it was recommended that patients monitat good and bid daily situatians during all treatment, and this was discussed with their doctors, and, when possithle, related to drinkirs behaviot. The following topics were standardized and applied to each patient during this treatment: management of negative mood. asser tivenes, dr ink re fisal skills, enhancement of social support networks, and relapse prevention.

The codes referent to the medications used were revesled to the researchers only after all patients had completed the study. Orily 2 pharmacists from the Pharmacy Sector at the Psychiatric lnstitute of the Clinical Haspital of the Univers ity of Ssio Paub knew what medication arres ponded to which specific ade, The packages containirs the capsules were distributed to patients by 2 trained research assistants, who had also been blinded in the study and who assessed the outcome of eadh patient throighout the study period.

\subsection{Stutistioal Analysis.}

We used the generalized estimating equations (GEE, Hedeker \& Githons 1997) approach, which acrommodated the repeated measure data and acrounted far within-subjed correlatans Non-normally distributed variables were log-transformed.

As twif of our sample discontinied the treatment we first used GEE to analyze the dafa of those who completed it. Lirtle's test was used to verily the missing-data medhanism Subsequently, we performed a mulliple-impatabon analysis with Markov Quain Mante Carla (MCMC. Hor bon \& Lipsitz, 2001; Gilks, Richurdson \& Spiegellwal ter, 1996) ap prowches and then used the GEI in SPS5-18. Maintaining the originat var iahility of the missitigdata was achieved by creatirg impated values based an variables assodinted with the cases of missing data.

In order to evaluate the predicting factors of dropouts, we analyzed the effect of tmultiple buse line variabies group members hip and typolagy an treatment retention by applying a longitudinal logistic regres. sian model with CEE featuring an autoreg ressive carrelation structure. We recoded the data into a dichotomous variable with either "abserved" or "missing" as the outcorne for this analysis.

The proportion of alstinenoe (XABS), and the proportion of hezvy drinking days (XIDD) were analyzed using the GEE model featuring autoregressive correlation struchure in both models (complete case and multiple imputed data set). Mean drinks per day and biomarkers were analyzed onily for completers using the GEI model.

Log-rank test was also used to evaluate diflerenos in retention by assignment condition Finally, we assessed the power of aur sample to detect diflerences befween both medication groups using CPower 3.1 (Faul, Erdfelder, Lang, \& Budhner, 2007).

For all statistical tests performed differences between the 2 groups were accepted as significant if they achieved the .05 level with two-biled tests. Da to were analyzed using SPSS 18 and Stata 9.

\section{Results}

\subsection{Sample characteristics}

As shown in Table 1 , all 102 selected participants were randomly assigned to 2 groups: $50(4902 X)$ in the ondansetron group, and 52 (5098x) in the plasebo group. There were no signiflcant differences between both groups, in ter ms of socio-demogr aphic data, buseline biochemical tests preferentivi beverages, and psychometric measures 
Dole 1

Buefine checteritis of ovea I sumple

\begin{tabular}{|c|c|c|c|}
\hline Cusacteriti & Racelos (n- 52 ) & Ondreneras $(a-50)$ & P \\
\hline Me, acese $\{50\}$ & $42 \mathrm{~B}\{9 \mathrm{QQ}\}$ & $4.66(10.14)$ & $s--77, \mathrm{BOdx}, \mathrm{p}-4.4$ \\
\hline \multicolumn{4}{|l|}{ 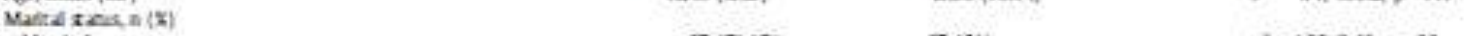 } \\
\hline Manked & $37(71.15)$ & $27(54)$ & \multirow[t]{3}{*}{$x^{2}-483,2 d t p-D S$} \\
\hline Senge & $4(7,9)$ & $\mathrm{n}(22)$ & \\
\hline Separant / Witoment & n $\{23.16\}$ & $2\{24\}$ & \\
\hline \multicolumn{4}{|l|}{ Face, $\mathrm{a}(\mathbf{X})$} \\
\hline Whe & $14\langle 2592\}$ & $2(40)$ & \multirow{3}{*}{$x^{x}-241,2 d t p=30$} \\
\hline Black & II (23.16) & II $(2)$ & \\
\hline Mloed & $27\langle 5492\}$ & $2\{38\}$ & \\
\hline \multicolumn{4}{|l|}{ Etucabon, = $(x)$} \\
\hline Gode 12 or ka & 12 $(61.54)$ & $34\{43\}$ & \multirow{2}{*}{$x^{2}-189,14 p-37$} \\
\hline Hilph sctuelormes: & $20\{39.46\}$ & $26(2)$ & \\
\hline 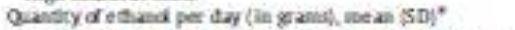 & $28500\{77142\}$ & 300.15 (20045) & $t=-42,00 d t, p=63$ \\
\hline 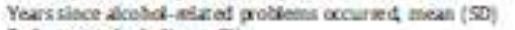 & $1311(841)$ & $1406(1133\}$ & $t=-4 a$, nodt $p=g$ \\
\hline 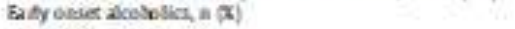 & $25(4805)$ & $25(90)$ & $x^{2}=.04,1 q, p-.85$ \\
\hline Nowolic sinckess, $\mathrm{V} / \mathrm{Q}$ & 玛 $\{\mathrm{a}, 46\}$ & $32(64)$ & $x^{2}<0$, 1 at, $p>\infty$ \\
\hline CRaretes prididy med (SD) & is $(12,78\}$ & 5.348 .377 & $t=-87$, at $p-38$ \\
\hline \multicolumn{4}{|l|}{ 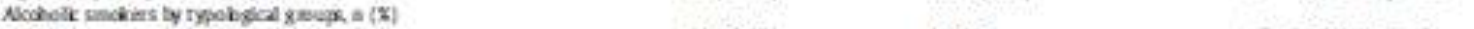 } \\
\hline EOA & $4(2552)$ & $4(28)$ & \multirow[t]{2}{*}{$x^{2}-2.55,34 t p-47$} \\
\hline in & is $(36.54)$ & $13 ; 36\}$. & \\
\hline Ramily hisary of alcokolisin, a (K) & $e(a, 5)$ & $3\langle 72\rangle$ & $x^{2}-108$ 14t $p-30$ \\
\hline 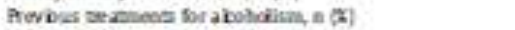 & 28 (9985) & $\boldsymbol{D}(39)$ & $x^{2}-18,1 d x-9$ \\
\hline \multicolumn{4}{|l|}{ 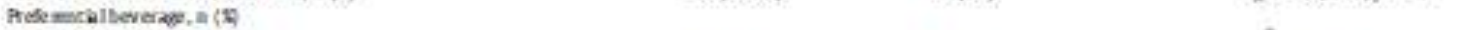 } \\
\hline Speutr: & $m(\bar{z})$ & $38(25)$ & \multirow[t]{3}{*}{ 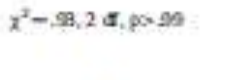 } \\
\hline Betr: & $22\{2903\}$ & D $\{24\}$ & \\
\hline Wine & I (169) & 0. & \\
\hline 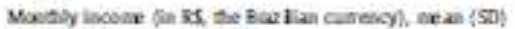 & $1418 \mathrm{n}(\mathrm{80099})$ & $347900\{1232,13\}$ & $t=-29$ vodt $p=\pi$ \\
\hline 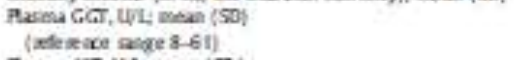 & 23575 (44691) & $47 a a(20046)$ & $\mathrm{U}=1 \mathrm{Bs}, \mathrm{p}-.49$ \\
\hline 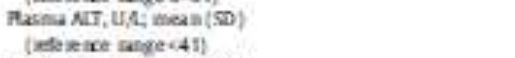 & $4140\{32.55\}$ & . 7.183529 & $\mathrm{~s}-33,100 \mathrm{df} p-74$ \\
\hline 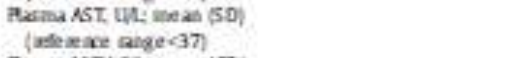 & $49 x(4.56)$ & $34.16[22.27\}$ & $U-1140, p=.67$ \\
\hline 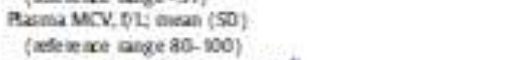 & $540(694)$ & $990(8.43)$ & $t-13,100$ it $p-9$ \\
\hline 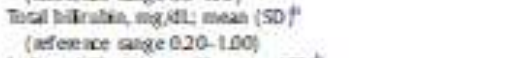 & $a s(02)$ & $0 \times(1020)$ & $t=1,47$, nodt $p=, 20$ \\
\hline 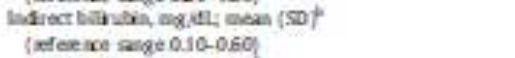 & $04\{041\}$ & $\Delta \rightarrow(\Delta 2)$ & $t-1.55$.00d4 $p=.12$ \\
\hline 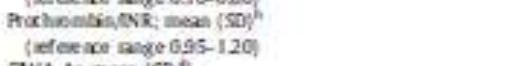 & os (a04) & $0 \times 8(004)$ & $t-127,000 \mathrm{dt}, p-.2 t$ \\
\hline CWA $A$, weal isof & $1389(899)$ & $1308,797)$ & $t-44,100$ if $p-10$. \\
\hline 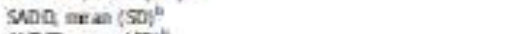 & $24 \theta(690)$ & 25,76 (a.11) & $t=-13,100 \mathrm{dt} p=17$ \\
\hline MDIT, neea (SD)" & 284 (iㅗ) & 2990 (5.11) & $t=-124,100 d t p-22$ \\
\hline$O C D S$ mea $=(S D)$ & $4473(20.19)$ & 46 (998) & $t=-85,00, d t, p-40$ \\
\hline HDSc areala $\$ 50\}$ & $996(545)$ & $84 \delta\{10\}$ & $t=105$, $000 \mathrm{dt} p-29$ \\
\hline
\end{tabular}

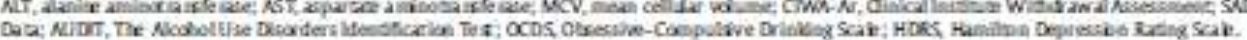

\subsection{Trabnent retention}

Overall, 51 patients dropped aut of the trial Reasons for dropout were classifted as refursl to continue (2\%), protocol vialatian (26\%) or lost to follow-up (720). Dropout rates amang participants randomized to placebo were $57,7 \mathrm{x}$, and $42 \mathrm{x}$ anong those randomiad to andansetron. This overall differe ice between bath groups was not significant ( $x^{2}=256,1 \mathrm{dI}, p=11$, Iog-rank test)

\subsection{Predicting facturs of treatment retentian}

The following variables were induded in a langitudinal lagistic regression model with GEE; age, maribl status race, educational level years since alcohol-related problems ocrurred, aloblolism typolasy, previous treatinent for alcoholism, preferential beverage, smoking status family hisbry of akcoholism medication group, and mean sonres on HDRS, CTWA-Ar, SADD, and OCDS of these var iables, only younger age and nons moking status were sigrificant y associated with earty discontinuation of treatment as it is shown in Table 2
Neither metication group nor alcoholism typokgy predicted treatment retention.

\section{Penernt absinent days and percert heavy drinking days}

All haselinevariables ( shown in Tahle 1) and those related to alcohol consumption at each appointnent were included in the amlysis of missing medhanism (Little's test), showing that the mechanism was not missing completely at random $\left(x^{2}(200)=431.57, p<011\right.$. Thus, We firstdecidet to andilyze the das from completers only.Subsequentby, we used the 2 variatiles (age and smoking status) that predicted missingness to c.rry out mul tiple-imputation analysis and to perform C.E on the total sample.

Considering only the smple composed of acherents, CEE analys is did not indicate a significant difference between ondarsetron and pla. cebo fat the XARS $\left|\chi^{2}(12)=1259, p=-40\right|$. Where anaverage, there Was $76: 1 \%$ occurrence of alstinence in the placebo group compared with $886 \%$ for andansetron actoss the medication period, illustrated in Fi. 2. In additian, neither aicoholism typoiagies $\left[x^{2}(12)=1344\right.$ 
Tale 2

\begin{tabular}{|c|c|c|c|c|c|}
\hline Varikas & Wult & $x$ & $\mathrm{p}$ & os & $\mathrm{d}(9 \mathrm{~g})$ \\
\hline Me: & 699 & 1 & $\cos ^{\circ}$ & 93 & 88. 98 \\
\hline \multicolumn{6}{|l|}{$\begin{array}{l}\text { Maribal scats } \\
\text { Mastiad (relemoe) }\end{array}$} \\
\hline Single & 287 & 1 & $\infty$ & 49 & $21-1.12$ \\
\hline Separdat/wusumed & .08 & 1 & .88 & 91 & $45-182$ \\
\hline \multicolumn{6}{|l|}{$\begin{array}{l}\text { Foe } \\
\text { Whis (nderisone) }\end{array}$} \\
\hline Blax & 177 & 1 & -3 & 31 & $.19-137$ \\
\hline Mired & 220 & $i$ & 27 & 1.4 & $.74-2.92$ \\
\hline \multicolumn{6}{|l|}{ 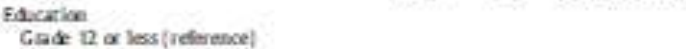 } \\
\hline High sctiol $\alpha$ more & 201 & 1 & 32 & 1,40 & $.73-2.68$ \\
\hline 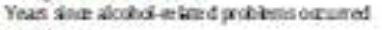 & 202 & 1 & $3:$ & $1, \infty 9$ & $97-109$ \\
\hline \multicolumn{6}{|c|}{ 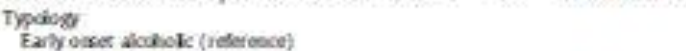 } \\
\hline Levener alcololic & .03 & 1 & $\$$ & $1, \infty$ & $43-2,72$ \\
\hline 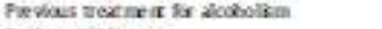 & 85 & 1 & 36 & 74 & $32-140$ \\
\hline \multicolumn{6}{|l|}{ 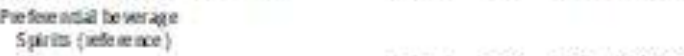 } \\
\hline Beet & 37 & 1 & 34 & 1,24 & $62-2.50$ \\
\hline Acotelic moles & 493 & 1 & $\mathrm{~B}^{*}$ & 51 & 28.2 \\
\hline \multicolumn{6}{|l|}{ Maticabon gap } \\
\hline $\begin{array}{l}\text { Planto (reberence) } \\
\text { Oantasenon }\end{array}$ & & & 27 & & \\
\hline Family yairosy of alcolvoism & 51 & 1 & 4 & 2.25 & $24-2058$ \\
\hline HDES & $<01$ & 1 & 94 & 9 & S3-IDE \\
\hline Cowar Ar & 36 & 1 & .5 & $\infty$ & $94-103$ \\
\hline suco & .73 & 1 & $\rightarrow$ & $1, \pi$ & $96-1.10$ \\
\hline OCDS & 49 & 1 & 48 & 99 & $95-103$ \\
\hline
\end{tabular}

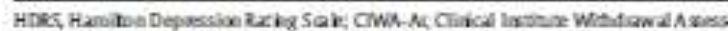

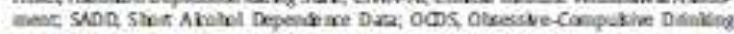
Scale.

in peDi.

$p=34$ ] not the interaction effect between medication groups and typalogy $\mid x^{2}(1)=2$. Ba, $p=09 \mid$ demanstrated staristical significanos dur ing the treatment Similarly, the GEI analysis did not demonstrat: a significant eflect of andansetron over pracebo for the $x \mathrm{FDD}$ $\left(x^{2}(12)=15.52, p=16\right]$, whereon- average, there was 9.5\%, occurreno: of hervy consumption in the planbo group compared with 59 :

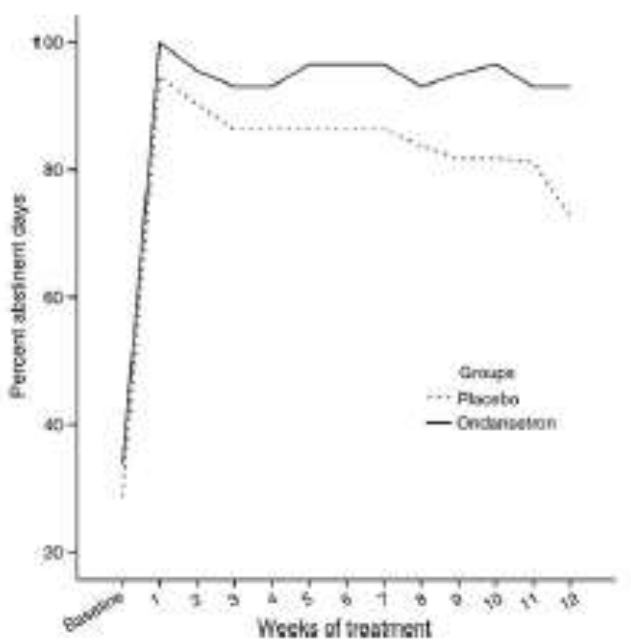

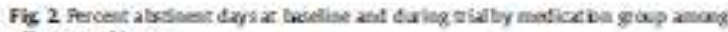
adierent sabjecs.

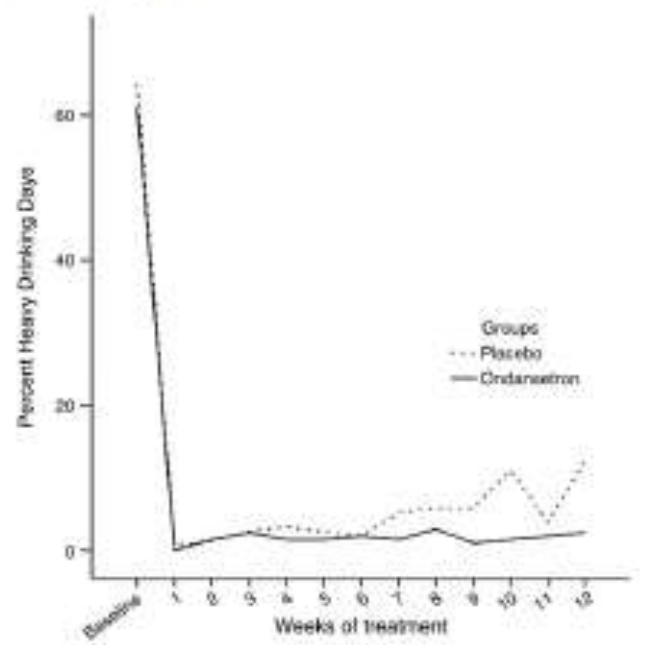

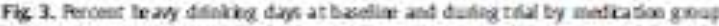
anoag aflerenr sebjects

for ondansetron across the medication period, illustrated in Fig. 3. In adfition, neither alcoholism ty polagies $\left|x^{2}(12)=17.41, p=09\right|$ not the interaction effect between medication groups and v polagy $\left|x^{2}(1)=265, p=-10\right|$ indicared statistical significance actoss the medication period.

When we consider the imputed sample (total sumple), the CEE analysis did not reveal a significant difference between ondansetron and placebo regarding the XABS $\left(x^{2}(12)=792, p=79\right.$. where on-average, there was $666 \%$ occurrence of abstinence in the plasebo group ampared with 7798 for ondanse tron across the medication period. In addition, neither akcoholism typalagies $\left[X^{2}(12)=11.92\right.$, $\mathrm{p}=-45$ ] not the interaction eflect between medication groups and typolosy $\left[x^{2}(1)=0.06, p=81\right]$ indicated statistical significanoe during the treatment Comersely, the CEE analysis demonstrated 2 significant effect of ondansetron over placebo regarding the STDD $\left.1 x^{2}(12)=2335, p=02\right\}$ where an-average, there was $11,7 x$ ocaurfence of heavy comsumption in the placebo gfoup to the $7.8 \%$ occurrence in the ondansetron group across the medication period. In addition alch holism ty polng ies revealed differences during the treatment $\left|x^{2}(12)=24.52, p=02\right|$ where on-average, there was $129 \%$ occurrence of heavy consumption in EOA compared with 7.1\% occurrence in $10 \mathrm{~A}$. The inter sction effert between medication groups and typolog $y\left(x^{2}(1)=73, p=39\right.$ ) did not indicate statisticas significanoe across the medication period.

35. Drintes per day, biamarless, and peychametric variables

Considering only the sanple campiset of adher ents, CEE atwlysis did not indicate a significant difference between ondansetron and placebo with regard to mean drinlos per $d a y\left(x^{2}(12)=15.49, p=22\right.$. where an-average, the placho group consimed $1.09(5 D=25)$ drinis, and the ondarsetran group consumed $66(S D=.18)$ drinks per day, as it is illustrated in Fz. 4. In addition, neither alcoholism typologies $\left.\mid x^{2}(12)=1316, p=36\right]$ not the interaction effect between medication groups and typology $\left|x^{2}(1)=91, p=34\right|$ demonstrated statistical significance during the treatment.

As shown in Table 3, consider ing only adherents (for whom all variables measured during the treatment were known), there were no signifficant differences between both medication groups throughout thisstudy in terms of bicamar kers and psychometr ic measures 


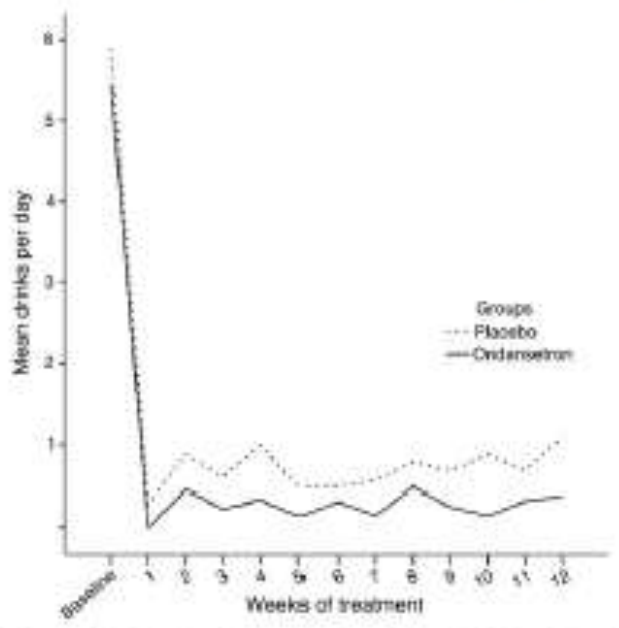

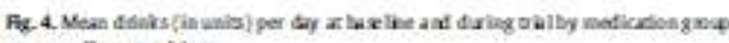
mag athen a a jers

\section{Safety and talenability}

The profile of side effecs by group is stown in Table 4. There were no statistically significant differences between both groups. Although patients in the ondansetron group more frequently reported consthpation, it was not significantly different from the placebo group.

\section{Integrity of the double-blind trial}

Researchers were queried regar ding what treatment they drought the patients were receiving in aldi bon thes ubjects were questianed at each study visit about the probable type of pharmacrlogica treatment they were recdiving. Overall, resestiders were able to correctly diflerentis. active treatment from placebo in $569 x$ of cases $\left(x^{2}=221,1\right.$ dt $p=14$ ) and $539 \%$ of the patients were able to differentiate active treatment correctly from placebo $\left(x^{2}=74,1 \mathrm{dt} p=39\right)$.

\section{Is somple power}

The G*Power stafis bcal program was used in a MANOVA for repented measures with tests of between-within interactian effects. The significance criterion was set at 05 , and the test used was bwo-tailed in order to calailate the sample pomer, we cansidered the completers sanple only.

Date 3

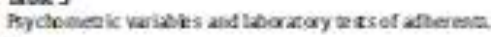

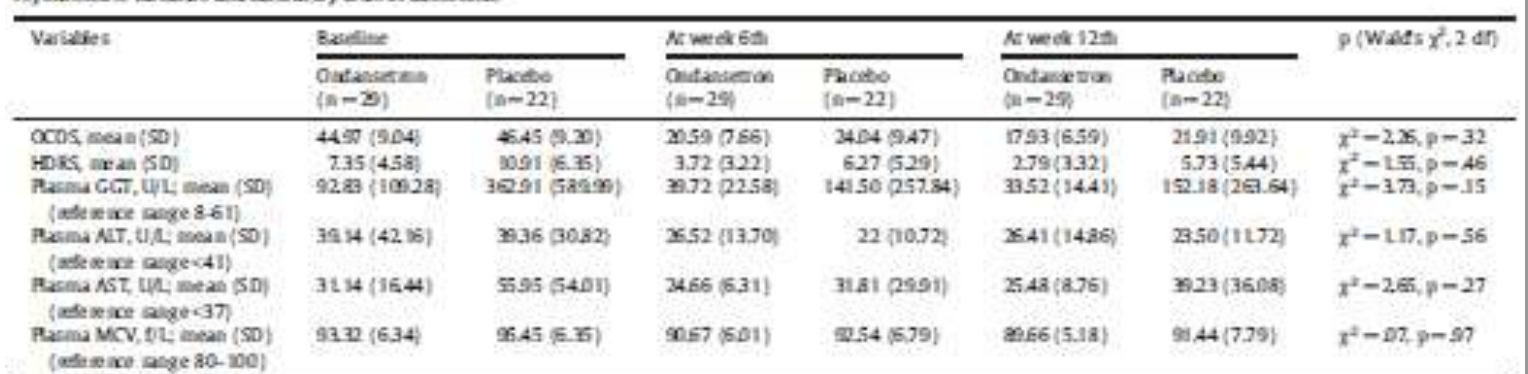

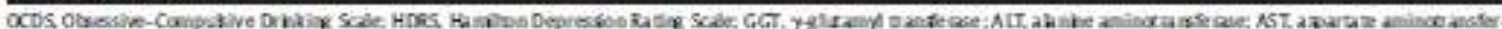

die, MCV, medincenlar volue

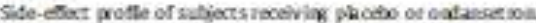

\begin{tabular}{|c|c|c|c|}
\hline Chical event & $\begin{array}{l}\text { Racelo }(n-52\} \\
\text { n (a) }\end{array}$ & $\begin{array}{l}\text { Ondazienos }\{\mathrm{n}-50\} \\
\text { o\{x\} }\end{array}$ & p [ith \\
\hline $\begin{array}{l}\text { Nobling reporned } \\
\text { Sombioince }\end{array}$ & $\begin{array}{l}26(30) \\
2(385)\end{array}$ & $\begin{array}{c}34(4) \\
1(2)\end{array}$ & $\begin{array}{l}x^{2}-14, p=-84 \\
x^{2}-30, p>x=\infty\end{array}$ \\
\hline $\begin{array}{l}\text { Heafacte } \\
\text { Dysprosia }\end{array}$ & $\begin{array}{l}9(17.31) \\
7(13.46\}\end{array}$ & $\begin{array}{l}7\{4\} \\
9\{13\}\end{array}$ & $\begin{array}{l}x^{2}-21, p-65 \\
x^{2}-39, p-53\end{array}$ \\
\hline $\begin{array}{l}\text { Darntea } \\
\text { Comsipasen }\end{array}$ & $\begin{array}{l}3(577) \\
6(11.54)\end{array}$ & $\begin{array}{l}1<2) \\
11(22)\end{array}$ & $\begin{array}{l}x^{2}-96, p=52 \\
x^{2}-202 p-.62\end{array}$ \\
\hline $\begin{array}{l}\text { Ceatiofinay } \\
\text { sympouss }\end{array}$ & $5(961)$ & $4(8)$ & $x^{2}-08, p-77$ \\
\hline Preatros & $3(577)$ & $3\langle 6\rangle$ & $x^{2}<00, p>>\infty$ \\
\hline
\end{tabular}

With fegards to the variable xA EN evaluated acrass the study, the sumple comprising 51 subjects adtieved 333 power to deted differences between the 2 tr aw trent groups versis the hypothesis of equality between both conditions. Theoretically, a sumple of 289 adherents would be necessary to adtieve $80 \%$ power with an eflect size flixed at 25. (Pillai's $V=05$, wills $\mathrm{X}=1806, \mathrm{~F}(12276)=1.79$, Considering that half the sample could drop out of 2 study with 2 similar design and components a total sample of 578 adherent subjects would be necessary to produos signiflicant results, at least from a theor efical point of view.

\section{Disarsion}

An ondansetron dase of $16 \mathrm{mg} / \mathrm{d} a \mathrm{y}$ was not significantly more eflective than a placebo in inc easing the proportion of atstinence dur ing this 12 -week randomized efficacy eval wation. Fifty percent of se lected participarts completed the stuxly and the main factors associated with treatment retention were older age and smoking sbofus. After multiple-imputation analysis, andarsetron was stightly but significantly more effective than piacsho in terms of decreasiog the proportion of heavy dr inking days.

High rates of discontinuation have been observed in other phatmacalogical trials for akcoholism (Baltieri. Daro, Ribeiro, \& Andr ack. 200; Johnson et al, 2007; Kranzler, Eccolar, Lee, \& Meza, 1996) However, it is possible to aflim that neither ondansetron nor placebo was linked to dropouts. There is some evidenos that some factors. such as older age and proactive participation of family members Penirati, \& Volpicelli. 2002). The literahure reveals mixed results regarding the eflect of smoiking on akcoholism treatment retention. Never theless, smoking may possess some copacity to help akoholics cope with urges $\mathrm{t}$ dr ink (Schmidt \& Smolka, 2007 ) and consequently increase athere nce to alm holism treatment. Some clinical and expetimental studies have sug gested that alcoholicsmokers could be interested in smaking cessation but prefer to address alcohol dependence are related to better treatment retention fGraff et al., 2009; Oslin, 
prior to embur king on quitting smoking, given the diflicul ty in stop. ping both drugs at the same time (Baitieti, Dara, Ribeiro, \& Andrade, 2009; Elingstad, Sobell Sobell, Cleland \& Agrawal, 1999; Joseph. Willenbring, Nugent, \& Nelson, 2004).

Ondansetron had a farable side-eflect ptoflle In this study, at. though the inost comman adverse effects of ondansetron weredyspepsi. and constipation, there were $\mathrm{m}$ differences beween both medicabion groups One could presume that the fuil-dose ondans dron could have contributed to the high drupout rates in this stidy. Despite this the reported side-dfects beween the placebo and ondansetron groups were not diflerent In addi bon other studies on ondensetran efficacy in treating depressive and anxiely symptams (cancamitant to or even derived from other ilineser) have sucressully tested doily doser between 8 and $24 \mathrm{mg}$ reporting a reduction in depressive symptams (Faris et al. 2006; Harmer, Reid, Ray, Good win, \& Cowen, 2006; Picheet al, 2005), decrexe of anxiety in subjerts with obsessive-campulsive disorder (5Giltan et al, 2010), and even improvement of angnitive impaiments among schimphrenics (Alkhondzadeh et al, 2009, Bennett \& Vila, 2010), In add6. tian. $8 \mathrm{mg}$ andansetron (but not $4 \mathrm{mg}$ ) was shown to be ueeful for decrezsing signs of opiate withdramal (Chu et al, 2009; Sell, Cowen, \& Roksan, 1995)

There are some explanvtions bo the inefficacy of ond nsetton at a dosige of $16 \mathrm{mg} / \mathrm{dry}$ in this stuxly. First, this study was undes - powered and of insufficient sample size, it can be true that ondensetron has some effect at a "full" dose, but this was only seen after inputision for dropouts Second previous studies have sugses ted that high andinsetr an doses do not wark very well. In fact a Ushaped mon-manotonic dase-response tus been observed for EOA. with a $4 \mu \mathrm{g} / \mathrm{Kg}$ hid dose working better than a higher ( $16 \mu \mathrm{\mu g} / \mathrm{K}_{\mathrm{S}}$ bid $)$ or a bower dose $(1 \mu \mathrm{g} / \mathrm{K}$ s bid (johnon et al, 2000; Kramler et at, 2003). Third, our sample moxtly comprised severely akohol-dependent indfividuak. According to Sellers et al ( 1994 ) andansetron appears b be fess effective for treating heavy drinkers than light drinkers. Fourth, stuxties heve shown andansetran is significantly mose dficacjous in reducing drinding severity in daholdependent individusis carrying the LI. Eenotype of the serotanit trans portet-linked polymarphic region (5 -HTTLPR) compared with the LS ar SS genotype (Kenn et aL 2009). Hence onty those donholdependent individuals with a specific allelic mnstitution of the serotonit transporter gene (5-1IT) could be treated succesdully, independesitly of the age of anset of problem dritiking (Johnson et aL, 201 1). Interest ingly, studies using samples of the Brazilian population hove showed higher frequency of 5 alleie, even when ethinic groups are separated (Meira-Lima et al, 2005; Mendes de Ol weita et al, 1998). This might be attributed to the great admixture of races occurring in Brabl as the majority of the population are rela tively recent immigrants (Parra et al, 2003)

Participants shoved high CGT levels at haseline One explation f this is that our simple comprised mainly spirits drinkers, and somes thdies havereported higherincidende of liver damage anong spirits drinkers then beer ar wine drinkers (Cronbadk et al 2004; Kerr et af 2000). In add ition, spirits can contain high levels of higher alcolok mainly in illid of torne-produced beverages (1.uchenmaer et al, 2008).

Our study shows that high doses can be saftly used. Though furthe researth comparing high doses with the mudh smaller doses used previousty woukd be interesting, the study design would dearly need to be sufficiently powered to campare different doses atainst a third placebo arm, and further adjusting for the L/S genotype eflect, as well as ary possible age-of-onset effects

We must cite several weaknesses in our study design;

(1) There were no other psychotherapeutic procedures assaciated with the pharmucological treatine if and behaviaral management that could increase the compliance of the patients and the effectiveness of the trea tnent;

(2) The number of dropouts in this study was high, probubly dy to the design. Which allowed patients to follow the standard community-based treatment programs without norms to incressepatient retention Aithough this approach b trial design, which allows normal life events to influence trial outcame. probatily enhances external validity, if can lead to consider atie difficulties in interpreting data, such as motives for relapse and premature discontinuation of follow-ip:

(3) Our service is exclusively dedicated to the treatment of men with alcohol and/or other drug froblems. There fore, our find ings cannot be extended to wamen.

(4) A larger sample size would have been required to provide higher power for this comparison;

(5) Althoigh we used ECC and clinical evaluation of out patients through anamnesis and cardiac auscultation at screening aniy clinical evaluation, but not ECG was onducted at each appointment during the study;

(6) Although we tested akohol breath concentration at baseline, we did not analyze breath akcohol levels acrass the study to confirm self-teport;

(7) There was no follow-up of participants after medication ceases at 12 weeks This can be disappointing as the outcomes in Figs, 2 and 3 seem to show a trend toward increasing henefir for the active group toward the end of the study. Altinough the dropout rate is likely to incresseance participans are no longer receiving medication, longer-term relapse data could tave significantly improved the trial

In summary, our study was not able to show the efficacy d ondansetron at a $16 \mathrm{mg} / \mathrm{day}$ dos ge to treat akohal dependent outpa tients, using only the treatinent atherents. With an imputed sample, ondansetron was significantly effective in decreasing the propartion of heavy drinking days. Although multiphe imputation is a valuatile tecinique that allows the use of complete-das statistics on das seti with missirg data, the true missing data mechunism will atways be elusive and untestable from the duta, and no amount of complex modelins can avercome this. Thus, the superiority of andinsetron over the placebo regarding the propartion of heavy drinking days in the imputed sample must be carefully considered in the interpretation of the data Nevertheless, our study showed fulldase ondansetron was clinically safe, and no serious side effects were reginter et. In addition, our study highlighes the need of contining medikation and mare intensive psy. chosocial treatments early in treatment in order to incresse treatment retention (Boltieri \& Correa Fitha, 2012).

\section{Bole $d$ flanding soure}

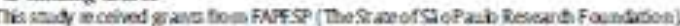

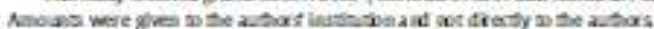

\section{Combiluatas}

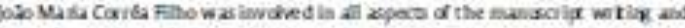

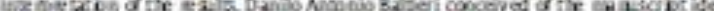

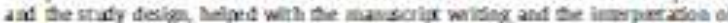
the results.

\section{Confinct of loteres}

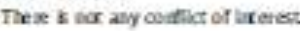

\section{Ademowinatgene nits}

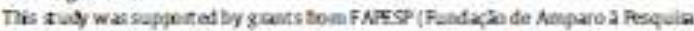

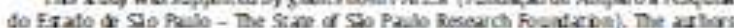

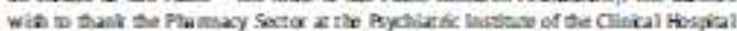
of the Unversy or sib Palo - Bapli

\section{Refenences}

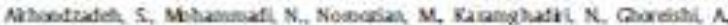

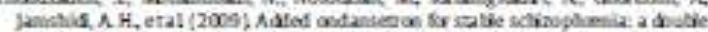

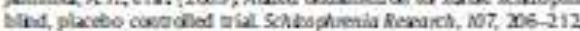

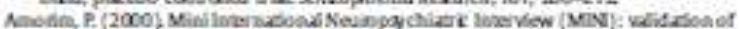

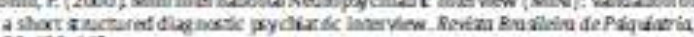
2. 2 hat $106-115$. 


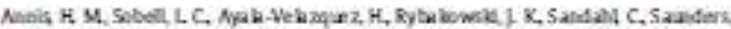

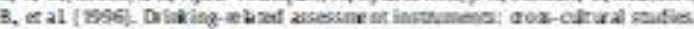

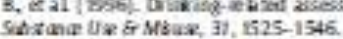

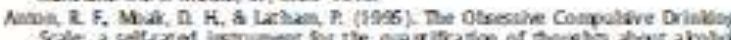

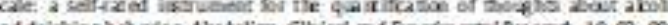

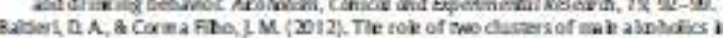

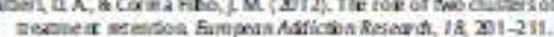

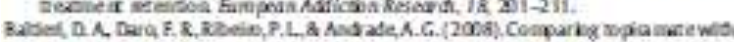

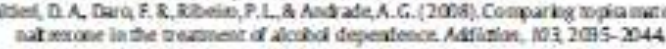

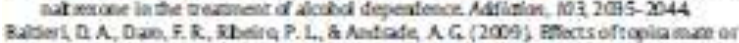

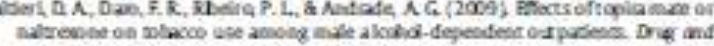

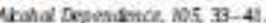

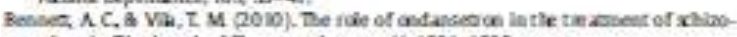

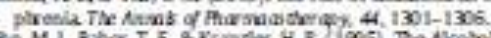

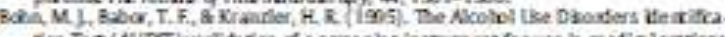

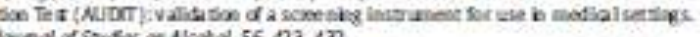

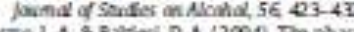

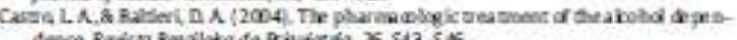

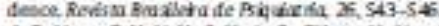

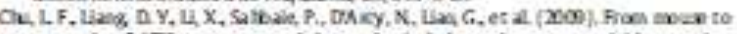

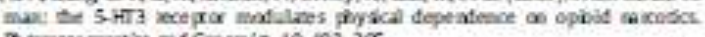

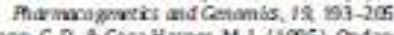

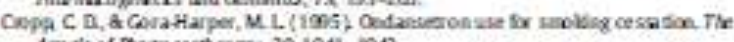

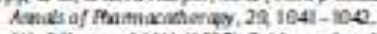

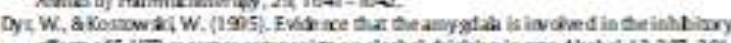

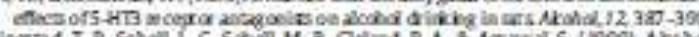

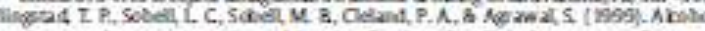

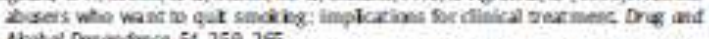
Nhidid Depomintice, 54, 259-2ef.

Fal, A, Cocinese, M, Mera G, Swarese, A, Cainandis, D, Nusm, C. M, etal (2008)

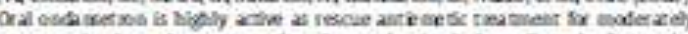

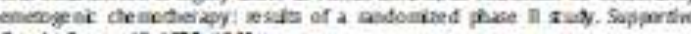
are it Cances, $16,1375-139$

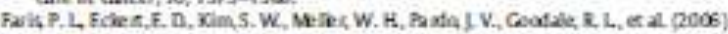

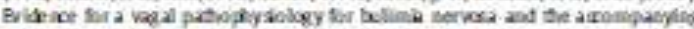

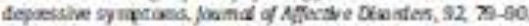

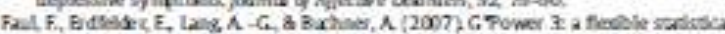

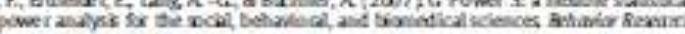
Mestat, $29,176-19 n$.

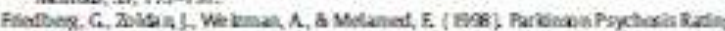

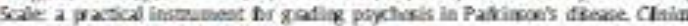
Nonplurinatoby, 21, 290-284.

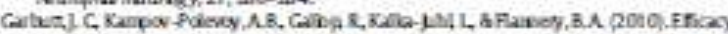

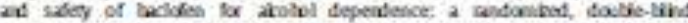

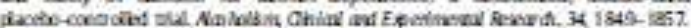

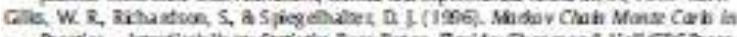

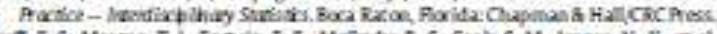

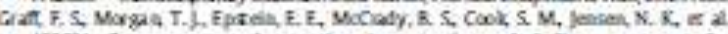

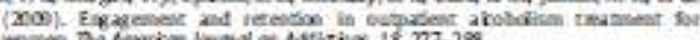

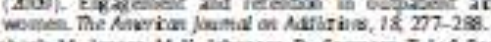

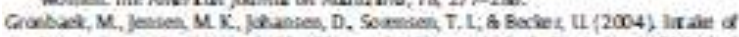

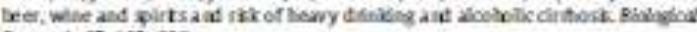
Reseurd, $37,196-20 \mathrm{C}$

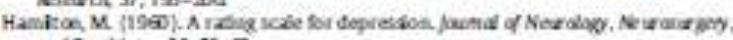

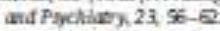

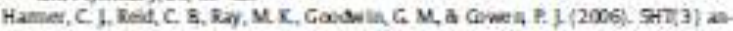

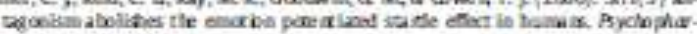
masiog. $A B E$ is 24 .

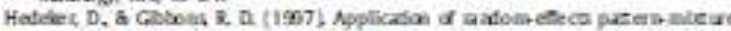

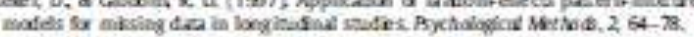

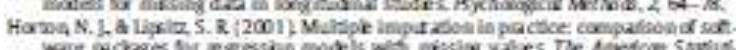
cint $5,244-254$

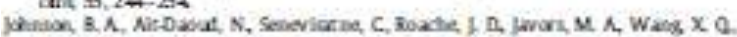

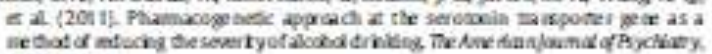
ife $265-275$

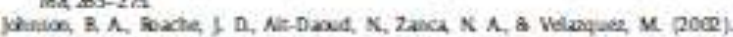

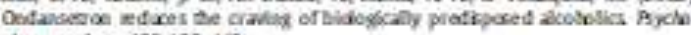

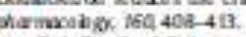

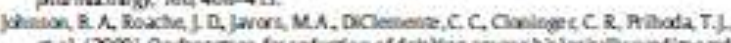

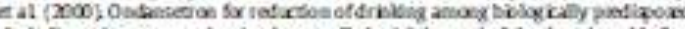

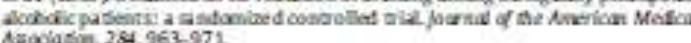

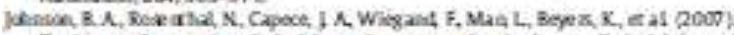

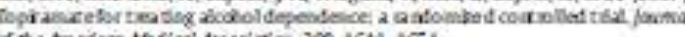

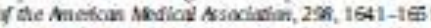

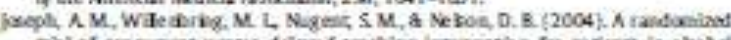

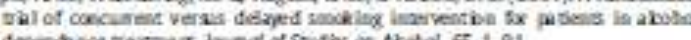

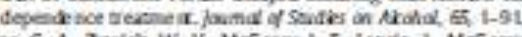

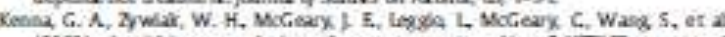

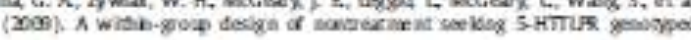

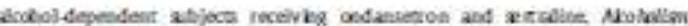

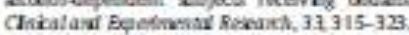

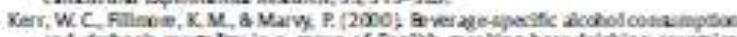

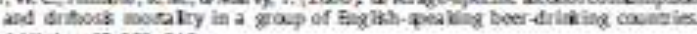
Adrcoton of, 3n- 346

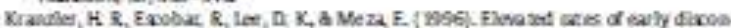

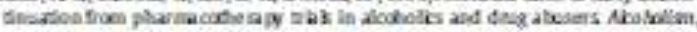

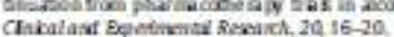

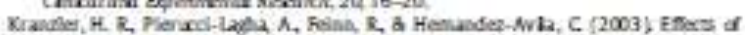

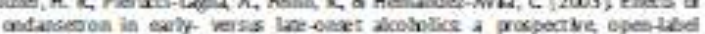

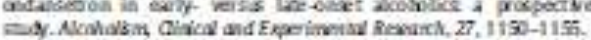

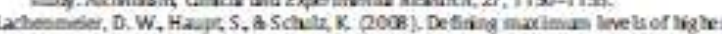

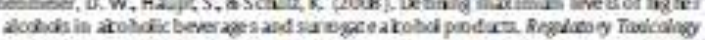

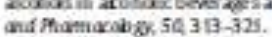

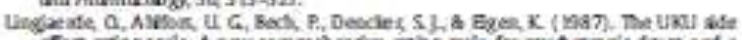

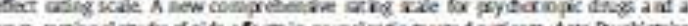

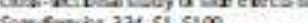

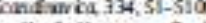

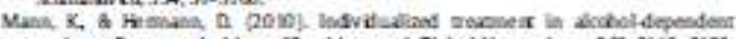

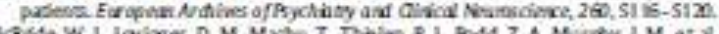

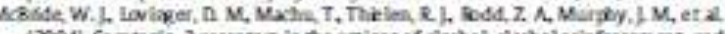

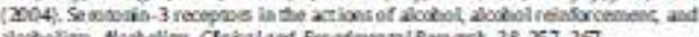

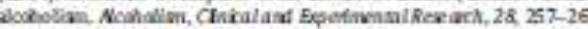

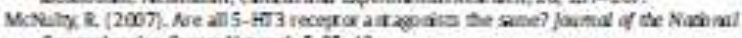

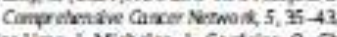

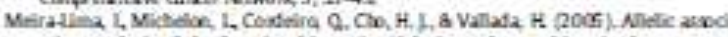

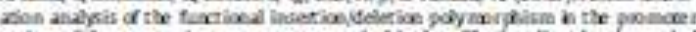

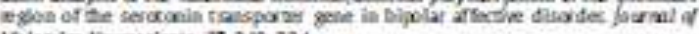

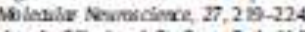

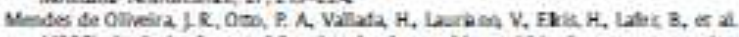

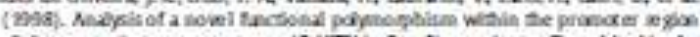

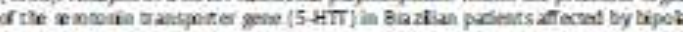

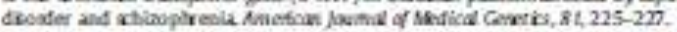

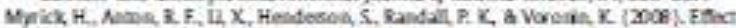

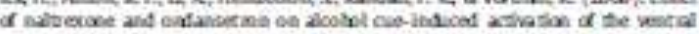

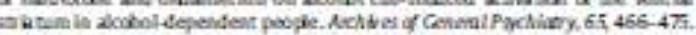

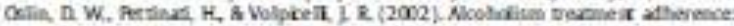

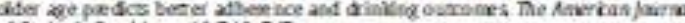
d Ceriuste Aychingy, $10740-74$

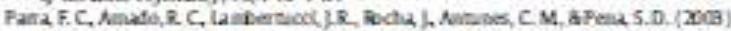

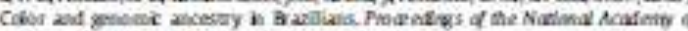
Sclinges of the livitud Sizes of Anverica, $10,177-182$

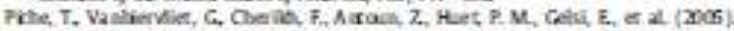

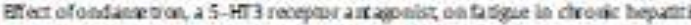

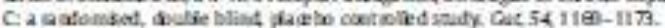

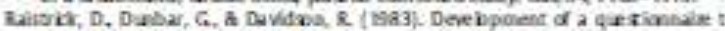

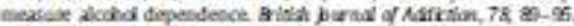

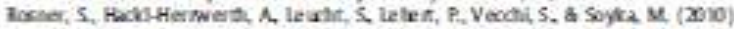
Coxodz32

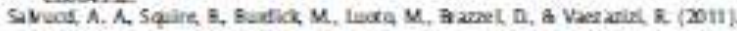

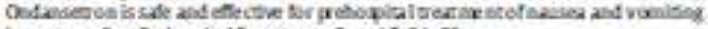

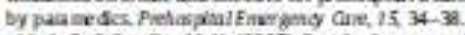

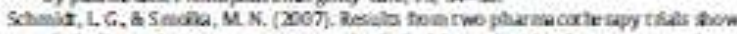

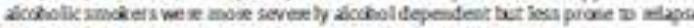

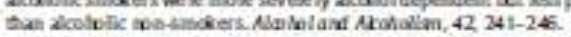

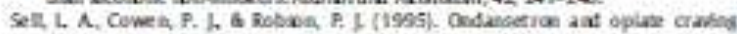

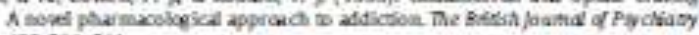
i66, $511-514$

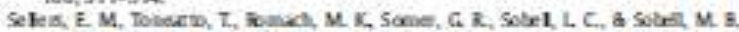

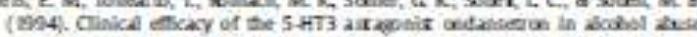

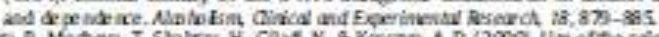

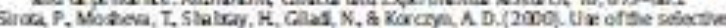

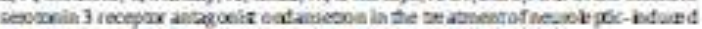

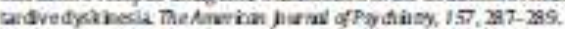

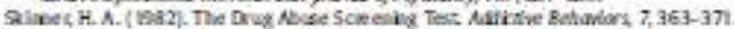

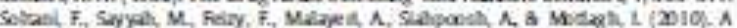

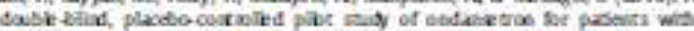

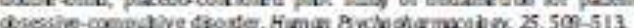

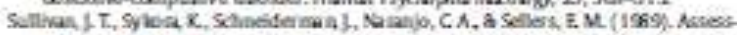

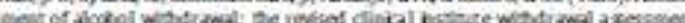

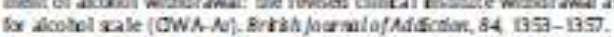

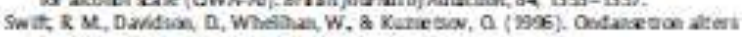

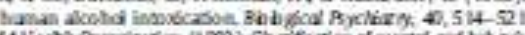

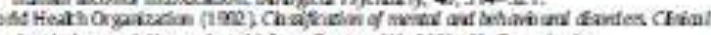

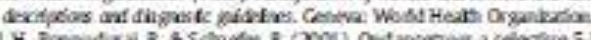

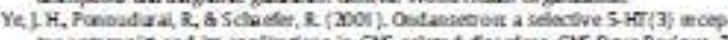

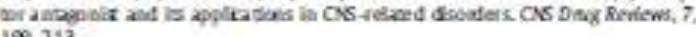

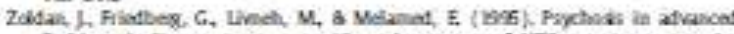

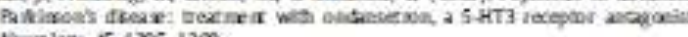
Newalage: 45, 1305-1308. 


\section{REFERÊNCIAS}

Abdo EM, Correia-Silva JF, Gomes CC, Pordeus IA, Gomez RS. Serotonin transporter gene polymorphisms: a case-control study. Braz Dent J. 2012;23(1):68-71.

Ait-Daoud N, Johnoson BA, Prihioda TJ, Hargita ID. Combining ondansetron and naltrexone reduces craving among biologically predisposed alcoholics: preliminary clinical evidence. Psychopharmacology (Berl). 2001;154(1):23-7.

Akhondzadeh S, Mohammadi N, Noroozian M, Karamghadiri N, Ghoreishi A, Jamshidi AH, Forghani S. Added ondansetron for stable schizophrenia: a double blind, placebo controlled trial. Schizophr Res. 2009;107(2-3):206-12.

Andrade AG, Duarte PCAV, Oliveira LG. I Levantamento Nacional sobre o Uso de Alcool, Tabaco e Outras Drogas entre Universitários das 27 Capitais Brasileiras. Brasilia: Secretaria Nacional de Politicas sobre Drogas; 2010.

Andrade AG, Bernick MA, Brunfentrinker P, Negro Jr PJ. Dados de Confiabilidade sobre uma entrevista semi-estruturada para avaliação de tratamento de alcoolistas: escala de severidade de alcoolismo (ESA). Rev ABP-APAL. 1988;10(1):1-4.

Annis HM, Sobell LC, Ayala-Velasquez H, Rybakowshi JK, Sandahl C, Saunders B, Thomas S, Ziolkowski M. Drinking-related assessment instruments: cross-cultural studies. Subst Use Misuse. 1996;31(11-12):152546.

Anthony JC. Consumo nocivo de álcool: dados epidemiológicos mundiais. In: Andrade AG, Anthony JC, editores. Álcool e suas consequencias: uma abordagem multiconceitual. Barueri: Minha Editora; 2009. p.1-36

Anton RF, O'Malley SS, Ciraulo DA, Cister RA, Couper D, Donovan DM, Gastfriend DR, Hosking JD, Johnson BA, Locastro JS, Longabaugh R, Mason BJ, Mattson ME, Miller WR, Pettinati HM, Randall CL, Swift R, Weiss RD, Williams JD, Zweben A. Combined pharmacotherapies and behavioral interventions for alcohol dependence: the COMBINE study: a randomized controlled trial. JAMA. 2006;295(17):2003-17.

Anton RF, Moak DH, Lathamp P. The obsessive compulsive drinking scale: A new method of assessing outcome in alcoholism treatment studies. Arch Gen Psychiatry. 1996;53:225-231.

Anton RF, Moak DH, Lathamp P. The obsessive compulsive drinking scale: a self-rated instrument for the quantification of thoughts about alcohol and drinking behavior. Alcohol Clin Exp Res. 1995;19:92-99. 
American Psychiatric Association. Diagnostic and Statistical Manual of Mental Disorders. 4a ed. Washington, DC: American Psychiatric Press, 1994.

American Psychiatric Association. American Psychiatric Association Guideline for the Treatment of Psychiatric Disorder, Compendium. Washington, DC: American Psychiatric Press, 2006.

Arias AJ, Sewell RA. Pharmacogenetically driven treatments for alcoholism: are we there yet? CNS Drugs. 2012;26(6):461-76.

Armando YP. Avaliação da bioequivalencia entre comprimido convencional e comprimido de desintegração oral contendo 8mg de ondansetrona [tese].São Paulo: Faculdade de Medicina, Universidade de São Paulo; 2008.

Arnone D. Review of the use of Topiramate for treatment of psychiatric disorders. Ann Gen Psychiatry. 2005;4(1):5-19.

Atkinson RM, Misra S, Ryan SC, Tuner JA. Referral paths, patient profiles and treatment adherence of older alcoholic men. J Subst Abuse Treat. 2003;25(1):29-35.

Auty $\mathrm{RM}_{2}$ Branch RA. Pharmacokinetics and pharmacodynamics of ethanol, whiskey, and ethanol with n-propyl, n-butyl, and iso-amyl alcohols. Clin Pharmacol Ther. 1977;22(2):242-9.

Babor TF, Caetano R. Subtypes of substance dependence and abuse: implications for diagnostic classification and empirical research. Addiction. 2006;101(1):104-10.

Babor TF, Hofmann M, Del-Boca FK, Hesselbrock V, Meyer RE, Dolinsky ZS, Tupes of alcoholics, I: evidence for an empirically derived typology based on indicators of vulnerability and severity. Arch Gen Psychiatry. 1992a;49:599-08.

Babor TF, Higgins-Bidddle JC, Saunders J, Monteiro MG. AUDIT - The Alcohol Use Disorders Identification Test: Guidelines for use in Primary Care. 2a ed. World Health Organization: Geneva, 1992b.

Baekelmand F, Lundwall L. Dropping out of treatment: a critical review. Psychol Bull. 1975;82(5):739-83.

Baltieri DA, Corrêa Filho JM. Role of two clusters of male alcoholics in treatment retention. Eur Addct Res. 2012;18(4):201-11.

Baltieri DA, Daró FR, Ribeiro PL, Andrade AG. Effects of topiramate or naltrexone on tobacco use among male alcohol-dependent outpatients. Drug Alcohol Depend. 2009a;105(1-2):33-41. 
Baltieri DA, Daró FR, Ribeiro PL, Andrade AG. The role of alcoholic beverage preference in the severity of alcohol dependence and adherence to the treatment. Alcohol. 2009b;43(3):185-95.

Baltieri DA, Daró FR, Ribeiro PL, Andrade AG. Comparing topiramate with naltrexone in the treatment of alcohol dependence. Addiction. 2008;103(12):2035-44.

Baltieri DA, De Andrade AG. Acamprosate in alcohol dependence: a randomized controlled efficacy study in a standard clinical setting. J Stud Alcohol. 2004;65(1):136-9.

Baltieri DA. Utilização do acamprosato no tratamento de dependentes de álcool [tese]. São Paulo: Faculdade de Medicina, Universidade de São Paulo; 2002.

Barnes NM, Sharp T. A review of central 5-HT receptors and their function. Neuropharmacology. 1999;38(8):1083-152.

Battino D, Croci D, Rossini A, Messina S, Mamoli D, Perucca E. Topiramate pharmacokinetics in children and adults with epilepsy: a case-matched comparison based on therapeutic drug monitoring data. Clin Pharmacokinet. 2005;44(4):407-16.

Bayard M, McIntyre J, Hill KR, Woodside J Jr. Alcohol withdrawal syndrome. Am Fam Physician. 2004;69(6):1443-50.

Beardsley PM, Lopez OT, Gullikson G, Flynn D. Serotonin 5-HT3 antagonists fail to affect ethanol self-administration of rats. Alcohol. 1994;11(5):389-95.

Bennett AC, Vila TM. The role of ondansetron in the treatment of schizophrenia. Ann Pharmacother. 2010;44(7-8):1301-6.

Bien TH, Miller WR, Toningan JS. Brief intervntions for alcohol problemas: A review. Addiction. 1993;88:315-336.

Biramijamal F, Basatvat S, Hossein-Nezhad A, Soltani MS, Akbari-Noghabi K, Irvanloo G, Shamimi K. Association of COX-2 promoter polymorphism with gastrointestinal tract cancer in Iran. Biochem Genet. 2010;48(11-12):915-23.

Bonadio AN, Figle NB. Terapias psicológicas de usuários e dependentes de álcool. In: Cordeiro DC, Figlie NB, Laranjeira R. Boas práticas no tratamento de uso e dependencia de substâncias. São Paulo: Roca; 2007. p.50-59.

Bozigian HP, Pritchard JF, Gooding AE, Pakes GE. Ondansetron absorption in adults: effect of dosage form, food, and antacids. J Pharm Sci. 1994;83(7):1011-3.

Brasil. Ministério da Saúde. Secretaria de Atenção à Saúde. Departamento de Ações Programáticas Estratégicas. Álcool e redução de danos: uma 
abordagem inovadora para pais em transição. Brasília: Ministerio da Saúde; 2004.

Brower KJ, Myra-Kim HM, Strobbe S, Karam-Hage MA, Consens F, Zucker RA. A randomized double-blind pilot trial of gabapentin vs. placebo to treat alcohol dependence and comorbid insomnia. Alcohol Clin Exp Res. 2008;32(8):1429-1438.

Brown JM. The effectiveness of treatment. In: Heather N, Peterst J, Stockwell $\mathrm{T}$. International handbook of alcoholism dependence and problems. New York: John Wiley \& Sons; 2001. p.497-508.

Bundy $\mathrm{C}$. Changing behaviour: using motivational interviewing techniques. $\mathrm{J}$ R Soc Med. 2004;97(Supl 44):43-7.

Capoccia VA, Cotter F, Gustafon DH, Cassidy EF, Ford JH, Madden L, Owens BH Farmum SO, McCarty D, Molfenter T. Making "stone soup": improvements in clinic access and retention in addiction treatment. Jt Comm J Qual Patient Saf. 2007;33(2):95-103.

Carlini EA, Galduroz JCF, Noto AR, Fonseca AM, Carlini CM, Oliveira LG, Nappo AS, Gonçalves de Moura Y, Sanches ZVDM. II Levantamento domiciliar sobre o so de drogas pscotropicas no Brasil, 2005: estudo envolvento as 108 maiores cidades do pais. Brasília: Secretaria Nacional Antidrogas; 2007.

Carlini EA, Galduroz JCF, Noto AR, Nappo SA. I Levantamento domiciliar sobre o uso de drogas psicotrópicas no Brasil: estudo envolvento as 107 maiores cidades do pais - 2001. São Paulo: CEBRID/Secretaria Nacional Antidrogas, 2001.

Carr CJA, Xu J, Redko C, Lane DT, Rapp RC, Gois J, Carlson RG. Individual and system influences on waiting time for substance abuse treatment. J Subst Abuse Treat. 2008;34(2):192-201.

Carroll KM. Recent advances in the psychotherapy of addictive disorders. Curr Psychiatry Rep. 2005;7(5):329-36.

Castro LA, Baltieri DA. Tratamento farmacológico da dependência do álcool. Rev Bras Psiquiatr. 2004;26(Supl 1):S43-6.

Charness ME. Overview of the chronic neurologic complications of alcohol. UptoDate. 2010 [citado 16 abr 2012]. Disponível em: https://webspace.utexas.edu/jnbarnes/PT_Lab/Lab_7_EtOH/Overview\%20of\%2 0the\%20chronic\%20neurologic\%20complications\%20of\%20alcohol.pdf.

Charney DA, Paraherakis AM, Negrete JC, Gill KL. The impact of depression on the outcome of addictions treatment. J Subst Abuse Treat. 1998;15:123130. 
Cheng $\mathrm{H}$, Tsang A, Huang $\mathrm{Y}$, Liu Z, Anthony JC, Kessler RC. The epidemological profile of alcohol and other drug use in metropolitan Chine. Int J Public Health. 2010;55(6):645-53.

Chick J, Kreitman N, Plant M. Mean cell volume and gamma-glutamyltranspeptidase as markers of drinking in working men. Lancet. 1981;1(8232):1249-51.

Chu LF, Liang DY, Li X, Sahbaie P, D’Arcy N, Liao G, Peltz G, David-Clark J. From mouse to man: the 5-HT3 receptor modulates physical dependence on opioid narcotics. Pharmacogenet Genomics. 2009;19(3):193-205.

Cloninger CR, Sigvardsson S, Bohman M. Type I and Type II alcoholism: an update. Alcohol Health Res World. 1996;20(1):18-23.

Cloninger CR, Bohman M, Sigvardsson S. Inheritance of alcohol abuse. Arch Gen Psychiatry. 1981;38:861-8.

Cordioli AV. Psicofármacos: Consulta Rapida. 4a ed. Porto Alegre: Artmed; 2011.

Davidson R. Questões motivacinais no tratamento do comportamento aditivo. In: Edwards G, Gross M, Keller M, Moser J, editores. Psicoterapia e tratamento das adições. Porto Alegre: Artes Médicas; 1997.

Dawes MA, Johnson BA, Ma JZ, Ait-Daoud N, Thomas SE, Cornelius JR. Reductions in and relations between "craving" and drinking in a prospective, open-label trial of ondasetron in adolescentes with alcohol dependence. Addict Behav. 2005;30(9):1630-7.

DiClemente CC, Prochaska JO. Self-change and therapy change of smoking behavior: a comparison of processes of change in cessation and maintenance. Addict Behav. 1982;7(2):133-42.

Dimeff LA, Marlatt GA. Relapse prevention. In: Hester RK, Miller WR, editores. Handbook of alcoholism treatment approaches: effective alternatives. 2a ed. Boston: Allyn and Bacon; 1995.

Doty $\mathrm{P}$, Zacny JP, De-Wit H. Effects of ondansetron pretreatment on acute responses to ethanol in social drinkers. Behav Pharmacol. 1994;5(4-5):461469.

Dubowski KM. Absorption, distribution and elimination of alcohol: highway safety aspects. J Stud Alcohol Suppl. 1985;10:98-108.

Edwards G, Marshall EJ, Cook CCH. O tratamento do alcoolismo: um guia para profissionais de saúde. 3a ed. Porto Alegre: Artes Médicas, 1999.

Edwards S, Kenna GA, Swift RM, Leggio L. Current and promising pharmacotherapies, and novel research target areas in the treatment os alcohol dependence: a review. Curr Pharm Des. 2001;17(14):1323-32. 
Ellingstad TP, Sobell LC, Sobell MB, Cleland PA, Agrawal S. Alcohol abusers who want to quit smoking: implications for clinical treatment. Drug Alcohol Depend. 1999;54(3):259-65.

Emrick CD. Alcoholics Anonymous: affiliation processes and effectiveness as treatment. Alcohol Clin Exp Res. 1987;11(5):416-423.

Enoch MA. The role of $\operatorname{GABA}(\mathrm{A})$ receptors in the development of alcoholism. Pharmacol Biochem Behav. 2008;90(1):95-104.

Faris PL, Eckert ED, Kim SW, Meller WH, Pardo JV, Goodale RL, Hartman BK. Evidence for a vagal pathophysiology for bulimia nervosa and the accompanying depressive symptoms. J Affect Disord. 2006;92(1):79-90.

Ferri M, Amato J, Davoli M. Alcoholics Anonymous and other 12-step programmes for alcohol dependence. Cochrane Database Syst Rev. 2006;(3):CD005032.

Fidalgo-Navarro A, Veiga-Villar J, Caminal-Monteiro L. Tratamiento de la encefalopatía de Wernicke. Rev Clin Esp. 2012;212(7):372-3.

Finney JW, Hahn AC, Moos $\mathrm{RH}$. The effectiveness of inpatient and outpatient treatment for alcohol abuse: the need to focus on mediators and moderators of setting effects. Addiction. 1996;91(12):1773-96.

Fiorentine R, Hillhouse MP. Exploring the additive effects of drug misuse treatment and twelve-step involvement: does twelve-step ideology matter? Subst Use Misuse. 2000;35(3):367-397.

Flannery BA, Poole SA, Gallop RJ, Volpicelii JR. Alcohol craving predicts drinking during treatment: an analysis of three assessment instruments. $J$ Stud Alcohol. 2003;64(1):120-6.

Folland J, Leach B, Little T, Hawker K, Myerson S, Montgomery H, Jones D. Angiotensin-converting enzyme genotype affects the response of human skeletal muscle to functional overload. Exp Physiol. 2000;85(5):575-9.

Fonseca AM, Galduroz JCF, Noto AR, Carlini EA. Comparation between two household surverys on psychotropic drug use in Brazil: 2001 and 2004. Cien Saude Colet. 2010;15(3):663-70.

Galanter M, Dermatis H, Mansky P, Mclntyre J, Perez-Fuentes G. Substance-abusing physicians: monitoring and twelve-step-based. Am J Addict. 2007;16(2):117-23.

Gallant DM, Bishop MP, Stoy B, Faulkner MA, Paternostro L. The value of a first contact: group intake session in an alcoholism outpatient clinic: statistical confirmation. Psychosomatics. 1966;7(6):349-52.

Garburtt JC, West SL, Carey TS, Lohr KN, Crews FT. Pharmacological treatment of alcohol dependence. A review of the evidence. JAMA. 1999;281(14):1318-25. 
Gately I. Drink: A cultural History of alcohol. New York: Gotham Books; 2008.

Sociedade Bíblica do Brasil. Biblia de Estudo Despertar. Barueri: Sociedade Bíblica do Brasil, 2005. Gênesis 9.20-21. Mudar citação

Gerlach J. New antipsychotics: classification, efficacy, and adverse effects. Schizophr Bull. 1991;17(2):289-309.

Gigliotti AB, Bessa MA. Síndrome de Dependência do Álcool: critérios diagnósticos. Rev Bras Psiquiatr. 2004;26(1):11-13.

Goodin S, Cunningham R. 5-HT(3)-receptor antagonists for the treatment of nausea and vomiting: a reappraisal of their side-effect profile. Oncologist. 2002;7(5):424-36.

Graff FS, Morgan TJ, Epstein EE, McCrady BS, Cook SM, Jensen NK, Kelly $\mathrm{S}$. Engagement and retention in outpatient alcoholism treatment for women. Am J Addict. 2009;18(4):277-88.

Gross M. Alcoholics Anonymous: still sober after 75 years. Am J Public Health. 2010;100(12):2361-3.

Hamilton M. A rating scale for depression. J Neurol Neurosurg Psychiatry. 1960;23:56-62.

Hanley JA, Negassa A, Edwardes MD, Forrester JE. Statistical analysis of correlated data using generalized estimating equations: Am J Epidemiol. 2003;157(4):364-375.

Harmer CJ, Reid CB, Ray MK, Goodwin GM, Cowen PJ. 5HT(3) antagonism abolishes the emotion potentiated startle effect in humans. Psychopharmacology (Berl). 2006;186(1):18-24.

Hasin DS, Stinson FS, Ogburn E, Grant BF. Prevalence, correlates, disability, and comorbidity of DSM-IV alcohol abuse and dependence in the United States. Arch Gen Psychiatry. 2007;64(7):830-842.

Hauser J, Rybakowski J. Three clusters of male alcoholics. Drug Alcohol Depend. 1997;48(3):243-50.

Heffner JL, Tran GQ, Johnson CS, Barret SW, Blom TJ, Thompson RD, Anthenelli RM. Combining motivational interviewing with compliance enhancement therapy (MI-CET): development and preliminary evaluation of a new, manual-guided psychosocial adjunct to alcohol-dependence pharmacotherapy. J Stud Alcohol Drugs. 2010;71(1):61-70.

Heinala P, Alho K, Lonnqvist J, Kuoppasalmi K, Sinclar JD. Targeted use of naltrexone without prior detoxication in the treatment of alcohol dependence: a factorial double-blind, placebo-controlled trial. J Clin Psychopharmacol. $2001 ; 21(3): 287-92$. 
Heilig M, Egli M. Pharmacological treatment of alcohol dependence: target symptoms and target mechanisms. Pharmacol Ther. 2006;111(3):855-76.

Hser Y, Maglione M, Polinsky ML, Anglin MD. Predicting drug treatment entry among treatment-seeking individuals. J Subst Abuse Treat. 1998;15(3):21320.

Hewlett WA, Schmid SP, Salomon RM. Pilot trial of ondansetron in the treatment of 8 patients with obsessive-compulsive disorder. J Clin Psychiatry. 2003;64(9):1025-30.

Hillemarcher $\mathrm{T}$, Frielin $\mathrm{H}$, Wilhelm J, Heberlein A, Karaquille D, Bleich S, Lenz B, Kornhuber J. Indicators for elevated risk factors for alcoholwithdrawal seizures: an analysis using a random forest algorithm. J Neural Transm. 2012;119(11):1449-53.

Hillemarcher T, Bayerlein K, Reulbach U, Sperling W, Wilhelm J, Mugele B, Kraus T, Bonsch D, Kornhuber J, Bleich S. Influence of beer, wine and spirits consumption on craving. Addict Biol. 2005;10(2):181-6.

Hintzen AK, Cramer J, Karagulle D, Heberlein A, Frieling $\mathrm{H}$, Kornhuber J, Bleich S, Hillemacher T. Does alcohol craving decrease with increasing age? Results from a cross-sectional study. J Stud Alcohol Drugs. 2011;71(1):15862.

Hoffman KA, Ford JH, Tillotson CJ, Choi D, McCarty D. Days to treatment and early retention among patients in treatment for alcohol drug disorders. Addict Behav. 2011;36(6):643-7.

Hoffman RS, Weinhouse GL. Management of moderate and severe alcohol withdrawal syndromes. Uptodate; 2011 [citado 19 dez 2011]. Disponivel em: https://webspace.utexas.edu/jnbarnes/PT_Lab/Lab_7_EtOH/Management\%2 0of\%20moderate\%20and\%20severe\%20alcohol\%20withdrawal\%20syndrom es.pdf.

Humpherys K, Mankowski ES, Moos RH, Finney JW. Do enhanced friendship networks and active coping mediate the effect of self-help groups on substance abuse? Ann Behav Med. 1999;21:54-60.

Humphreys K, Kaskutas LA, Weisner C. The relationship of pre-treatment Alcoholics Anonymous affiliation with problem severity, social resources and treatment history. Drug Alcohol Depend. 1998;49(2):123-131.

Instituto Nacional de Câncer. Inquérito domiciliar sobre comportamento de risco e morbidade referida de doença e agravos não transmissiveis: Brasil, 15 capitais e Distrito Federal, 2002-2004. Rio de Janeiro: Instituto Nacional de Câncer, 2004.

Jellinek EM. The Disease Concept of Alcoholism. New Brunswick: Hillhouse Press; 1960. 
Jerome HJ. The concept of dependence: historical reflections. Alcohol Health Res World. 1993;17:188-190.

Johnson BA, Ait-Daoud N, Seneviratne C, Roache JD, Javors MA, Wang XQ, Liu L, Penberthy JK, DiClemente CC, Li MD. Pharmacogenetic approach at the serotonin transporter gene as a method of reducing the severity of alcohol drinking. Am J Psychiatry. 2011;168(3):265-75.

Johnson BA. Update on neuropharmacological treatments for alcoholism: scientific basis and clinical findings. Biochem Pharmacol. 2008;75(1):34-56.

Johnson BA, Rosenthal N, Capece JA, Wiegand F, Mao L, Beyers K, McKay A, Ait-Daoud N, Ciraulo DA, Kranzler HR, Mann K, O`Malley SS, Swiff RM. Topiramate for treatment alcohol dependence: a randomized controlled trial. JAMA. 2007;298(14):1641-51.

Johnson BA, Roache JD, Ait-Daoud N, Javors MA, Harrison JM, Elkashef A, Mojsiak J, Li SH, Bloch DA. A preliminary randomized, double-blind, placebocontrolled study of the safety and efficacy of ondansetron in the treatment of cocaine dependence. Drug Alcohol Depend. 2006;84(3):256-63.

Johnson BA. Topiramate-induced neuromodulation of cortico-mesolimbic dopamine function: a new vista for the treatment of comorbid alcohol and nicotine dependence? Addict Behav. 2004;29(7):1465-79.

Johnson BA, Ait-Daooud N, Bowden CL, Declemente CC, Roache JD, Lawson K, Javors MA, Ma JZ. Oral topiramate for treatment of alcohol dependence: a randomised controlled trial. Lancet. 2003;361(9370):1677-85.

Johnson BA, Roache JD, Ait-Daoud N, Zanca NA, Velazquez M. Ondansetron reduces the craving of biologically predisposed alcoholics. Psychopharmacology (Berl). 2002;160(4):408-13.

Johnson BA, Ait-Daoud N, Prihoda TJ. Combining ondansetron and naltrexone effectively treats biologically predisposed alcoholics: from hypotheses to preliminary clinical evidence. Alcohol Clin Exp Res. 2000a;24(5):737-42.

Johnson BA. Serotoninergic agents and alcoholism treatment: rebirth of the subtype concept - an hypothesis. Alcohol Clin Exp Res. 2000b;24(10):1597601.

Johnson BA, Roache JD, Javors MA, Diclemente CC, Cloninger CR, Prihoda TJ, Bordnick PS, Ait-Daoud N, Hensler J. Ondansetron for reduction of drinking among biologically predisposed alcoholic patients: A randomized controlled trial. JAMA. 2000c;284(8):963-71.

Johnson BA, Campling GM, Griffiths P, Cowen PJ. Attenuation of some alcohol-induced mood changes and the desire to drink by $5-\mathrm{HT} 3$ receptor 
blockade: a preliminary study in healthy male volunteers. Psychopharmacology (Berl). 1993;112(1):142-4.

Jorge MR, Mansur J. Questionários padronizados para avaliação do grau de severidade da síndrome de dependência do álcool. J Bras Psiquiatr. 1986;35(5):287-92.

Jorgensen $\mathrm{CH}$, Pedersen $\mathrm{B}$, Tonnesen $\mathrm{H}$. The efficacy of disulfiram for treatment of alcohol use disorder. Alcohol Clin Exp Res. 2011;35(10):174958.

Joseph AM, Willenbring ML, Nugent SM, Nelson DB. A randomized trial of concurrent versus delayed smoking intervention for patients in alcohol dependence treatment. J Stud Alcohol. 2004;65(6):681-91.

Kampman KM, Pettinati HM, Lynch KG, Xie H, Dackis C, Oslin DW, Sparkman T, Sharkoski T, O`Brien CP. Initiating acamprosate withindetoxification of self-reported drinking post-detoxification in the treatment of alcohol dependence. Addict Behav. 2009;34(6-7):581-586.

Kahn D. The dichotomy of drugs and psychoterapy. Psychiatr Clin North Am. 1990;13(2):197-208.

Kenna GA, Zywiak WH, McGeary JE, Leggio L, Wang S, Greaga A, Swift RM. A within-group design of nontreatment seeking 5-HTTLPR genotyped alcohol-dependent subjects receiving ondansetron and sertraline. Alcohol Clin Exp Res. 2009;33(2):315-23.

Kessels $\mathrm{RP}_{2}$ Kopelman MD. Context memory in Korsakoff's syndrome. Neuropsychol Rev. 2012;22(2):117-31.

Kilpatrick GJ, Hagan RM, Gale JD. 5-HT3 and 5-HT4 receptors in terminal regions of the mesolimbic system. Behav Brain Res. 1996;73(1-2):11-3.

King GR, Xiong Z, Douglass S, Ellinwood EH. Long-term blockade of the expression of cocaine sensitization by ondansetron, a $5-\mathrm{HT}(3)$ receptor antagonist. Eur J Pharmacol. 2000;394(1):97-101.

Koulu M, Lappalainen J, Hietala J, Sjoholm B. Effects of chronic administration of ondansetron (GR38032F), a selective 5-HT3 receptor antagonist, on monoamine metabolism in mesolimbic and nigrostriatal dopaminergic neurons and on striatal D2-receptor binding. Psychopharmacology (Berl). 1990;101(2):168-71.

Kranzler HR, Pierucci-Lagha A, Feinn R, Hernandez-Avila C . Effects of ondansetron in early-versus late-onset alcoholics: a prospective, open-label study. Alcohol Clin Exp Res. 2003;27(7):1150-5.

Kranzler HR, Escobar R, Lee DK, Meza E. Elevated rates of early discontinuation from pharmacotherapy trials in alcoholics and drug abusers. Alcohol Clin Exp Res. 1996;20(1):16-20. 
Krentzman AR, Robinson EA, Moore BC, Kelly JF, Laudet AB, White WL, Zemore SE, Kurtz E, Strobbe S. How Alcoholics Anonymous (AA) and Narcotics Anonymous (NA) Work: Cross-Disciplinary Perspectives. Alcohol Treat Q. 2010;29(1):75-84.

Laranjeira R, Pinsky I, Zaleski M, Caetano R. I Levantamento Nacional sobre os padrões de consumo de álcool na população brasileira. Brasilia: Secretaria Nacional Antidrogas; 2007.

Laranjeira R, Nicastri S, Jerônimo C, Marques AC. Consenso sobre a Sindrome de Abstinencia do Álcool (SAA) e o seu tratamento. Rev Bras Psiquiatr. 2000;22(2):66-71.

Laranjeira R, Nicastri S. Abuso e Dependencia de Álcool e Drogas. In: Almeida OP, Dratcu L, Laranjeira R, editores. Manual de Psiquiatria. Rio de Janeiro: Guanabara Koogan; 1996. p.83-112

Latt NC, Jurd S, Houseman J, Wutzku SE. Naltrexone in alcohol dependence: a randomised controlled trial of effectiveness in a standard clinical setting. Med J Aust. 2002;176(11):530-4.

Leigh G, Ogborne AC, Polinsky ML, Anglin MD. Factors associated with patient dropout from an outpatient alcoholism treatment service. J Stud Alcohol. 1984;45(4):359-62.

Lesch OM, Walter H. Subtypes of alcoholism and their role in therapy. Alcohol Alcohol Suppl. 1996;1:63-7.

Lesch OM, Kefer J, Lentner S, Mader R, Marx B, Musalek M, Nimmerrichter $A$, Preinsberger $H$, Puchinger $H$, Rustembegovic $A$, Walter $H$, Zach $E$. Diagnosis of chronic alcoholism--classificatory problems. Psychopathology. 1990;23(2):88-96.

Lesch OM, Dietzel M, Musalek M, Walter H, Zeiler K. The course of alcoholism. Long-term prognosis in different types. Forensic Sci Int. $1988 ; 36(1-2): 121-38$.

Leggio L, Ferrulli A, Cardone S, Malandrino N, Mirijello A, D`Angelo C, Vonghia L, Miceli A, Capristo E, Kenna GA, Gasbarrini G, Swift RM, Addolorato $\mathrm{G}$. Relationship between the hypothalamic-pituitary-thyroid axis and alcohol craving in alcohol-dependent patients: a longitudinal study, Alcohol Clin Exp Res. 2008;32(12):2047-53.

Liese BS, Franz RA. Tratamento dos transtornos por uso de substância com a terapia cognitiva: lições aprendidas e implicações para o futuro. In: Salkovskis P. Fronteiras da terapia cognitiva. São Paulo: Casa do Psicólogo; 2005. p.405-36

Lima JMB. Alcoologia: uma visão sistêmica dos problemas relacionados ao uso e abuso de álcool. Rio de Janeiro: URFJ/EEAN; 2003. 
Lingjaerde O, Ahlfors UG, Bech P, Denker SJ, Elgen K. The uku side effect rating scale. Acta Psychiatr Scand. 1987;76(334):81-84.

Maciel C, Kerr-Correa F. Complicações psiquiátricas do uso crônico do álcool: síndrome de abstinência e outras doenças psiquiátricas. Rev Bras Psiquiatr. 2004;26(1):47-50.

Magura S, Cleland CM, Tonigan JS. Evaluating Alcoholics Anonymous's effect on drinking in Project MATCH using cross-lagger regression panel analysis. J Stud Alcohol Drugs. 2013;74(3):378-85.

Mann K, Kiefer F, Spanagel R, Littlelon J. Acamprosate: recent findings and future research directions. Alcohol Clin Exp Res. 2008;32(7):1105-10.

Marlatt GA, Gordon GR. Prevenção de recaída. Porto Alegre: Artes Médicas; 1994.

Marsui T, Sakurai H, Toyama T, Yoshimura A, Matsushita S, Higuchi S. Clinical application of neuroimaging to alcohol-related dementia. Jap $\mathrm{J}$ Alcohol Stud Drug Dep. 2012;47(3):125-34.

Marques ACPR. O uso do álcool e a evolução do conceito de dependência de álcool e outras drogas e tratamento. Rev IMESC. 2001;3:73-86.

Mason BJ. Acamprosate in the treatment of alcohol dependence. Expert Opin Pharmacother. 2005;6(12):2103-15.

McBride WJ, Li TK. Animal models of alcoholism: neurobiology of high alcohol-drinking behavior in rodents. Crit Rev Neurobiol. 1998;12(4):339-69.

McKernan RM, Rosahl TW, Reynolds DS, Sur C, Wafford KA, Atack JR, Farrar S, Myers J, Cook G, Ferris P, Garrett L, Bristow L, Marshall G, Macaulay A, Brown N, Howell O, Morre KW, Carling RW, Stret LJ, Castro JL, Ragam Cl, Dawson GR Whiting PJ. Sedative but not anxiolytic properties of benzodiazepines are mediated by the $\operatorname{GABA}(\mathrm{A})$ receptor alpha1 subtype. Nat Neurosci. 2000;3(6):587-92.

Mclntosh C, Chick J. Alcohol and the Nervous System. J Neurol Neurosurg Psychiatry. 2004;75(3):16-21.

Meire-Lima I, Michelon L, Cordeiro Q, Cho HJ, Vallada H. Allelic association analysis of the funcional insertion/deletion polymorphism in the promoter region of the serotonin transporter gene in bipolar affective disorder. $\mathrm{J} \mathrm{Mol}$ Neurosci. 2005;27(2):219-24.

Méndez BE. Uma versão brasileira do AUDIT: Alcohol Use Disorders Identification Test [dissertação]. Pelotas: Universidade Federal de Pelotas; 1999. 
Mendez DE Oliveira JR, Otto PA, Vallada H, Lauriano V, Elkis H, Lafer B, Vawquez L, Gentil V. Analysis of a novel funtional polymorphism in the promoter region of the serotonin transporter gene in bipolar affective disorder. Am J Med Genet. 1998;81(3):225-7.

Meyerhoff DJ, Tizabi Y, Stley JK, Durazzo TC, Glass JM, Nixon SJ. Smoking comorbidity in alcoholism: neurobiological and neurocognitive consequences. Alcohol Clin Exp Res. 2006;30(2):253-64.

Miller WR, Wilbourne PL. Mesa Grande: a methodological analysis of clinical trials of treatments for alcohol use disorders. Addiction. 2002;97(3):265-77.

Miller W, Yahne C, Tonigan S. Motivational interviewing in drug abuse services: a randomized trial. J Consult Clin Psychol. 2003;71(4):754-63.

Miller WR, Meyers RJ, Hiller-Sturmhofel S. The Community-reinforcement approach. Alcohol Res Health. 1999; 23(2):116-21.

Milton FA. Estrutura e ultraestrutura do epitélio uterino de ratas UChA e UChB - bebedoras voluntarias de álcool. [dissertação]. Campinas: Instituto de Biologia, Universidade de Campinas; 2006.

Morgenstern J, Longabaugh R. Cognitive-behavioral treatment for alcohol dependence: a review of evidence for its hypothesized mechanisms of action. Addiction. 2000;95(10):1475-90.

Monteiro CFS, Fé LCM, Moreira MAC, Albuquerque IEM, Silva MG, Passamani MC. Perfil sociodemográfico e adesão ao tratamento de dependentes de álcool em CAPS-ad do Piauí. Esc Anna Nery. 2011;15(1):90-5.

Monti PM, Rohsenow DJ. Coping-skills training and cue-exposure therapy in the treatment of alcoholism. Alcohol Res Health. 1999;23(2):107-15.

Monti PM, Rohsenow DJ, Colby SM, Abrams DB. Coping and social skills training. In: Hester RK, Miller WR, editores. Handbook of alcoholism treatment approaches: effective alternatives. 2a ed. Boston: Allyn and Bacon; 1995.

Moreno RA, Moreno DH. Escalas de depressão de Montgomery \& Asberg (MADRS) e de Hamilton (HAM-D). Rev Psiquiatr Clin. 1998;25(5):262-72.

Moyer A, Finney JW, Swearingen CE, Vergun P. Brief interventions for alcohol problems: a meta-analytic review of controlled investigations in treatment-seeking and non-treatment-seeking populations. Addiction. 2002;97:279-92.

Munro CA, Oswald LM, Weerts EM, Mccaul ME, Wand GS. Hormone resposes to social stress in abstinent alcohol-dependent subjects and social drinkers with no history of alcohol dependence. Alcohol Clin Exp Resp. 2005;29(7):1133-8. 
Myers WR. Handling missing data in clinical trials: an overview. Drug Infor J. 2000;34:525-33.

Myrick H, Anton RF, Henderson S, Randall PK, Voronin K. Effect of naltrexone and ondansetron on alcohol cue-induced activation of the ventral striatum in alcohol-dependent people. Arch Gen Psychiatry. 2008;65(4):46675.

Nakamura-Palacios EM. Escala de Avaliação de padrao obsessivo compulsivo para uso de álcool e drogas. 2002 [Encontro do Programa de Pós-Graduação em Ciências Fisiológicas]. Vitoria:Universidade Federal do Espirito Santo; 2002.

National Institute on Alcohol and Alcoholism - NIAAA. Helping patients who drink too much: a clinican's guide. 2005.[citado 2012 Ago 16].Disponivel em: http://www.pubs.niaaa.nih.gov/publications/Practitioner/

ClinicansGuide2005/guide.pdf.

National Institute on Alcohol and Alcoholism - NIAAA. Refines alcoholism treatment options. Alcohol Res \& Health. 2000;24(1):53-61.

Noto AR, Moura YG, Nappo S, Galduroz JCF, Carlini EA. Internação por transtorno mentais e de comportamento decorrente de substâncias psicoativas: um estudo epidemiológico nacional do periodo de 1988 a 1999. J Bras Psiquiatr.2002;51(2):113-21.

Organização Mundial de Saúde. CID-10. Classificação Estatística Internaciona de Doenças e Problemas Relacionados a Saúde, décima revisão. Porto Alegre: Artes Medicas; 1992.

Orme DR, Boswell D. The pre-intake drop-out at a community mental health center. Community Ment Health J. 1991;27(5):375-9.

Oslin DW, Lynch KG, Pettinati HM, Kampman KM, Gariti P, Gelfand L, Ten Have T, Wortman S, Dundon W, Dackis C, Volpicelli JR, O`Brien CP. A placebo-controlled randomized clinical trial of naltrexone in the context of different level of psychosocial intervention. Alcohol Clin Exp Resp. 2008;32(7):1299-308.

Oslin DW, Pettinati H, Volpicelli Jr. Alcoholism treatment adherence: older age predicts better adherence and drinking outcomes. Am J Geriatr Psychiatry. 2002;10(6):740-7.

Pallanti S, Bernardi S, Antonini S, Singh N, Hollander E. Ondansetron augmentation in treatment-resistant obsessive-compulsive disorder: a preliminary, single-blind, prospective study. CNS Drugs. 2009;23(12):104755.

Parkes $\mathrm{H}$, Sinclair JD. Reduction of alcohol drinking and upregulation of opioid receptors by oral naltrexone in AA rats. Alcohol. 2000;21(3):215-21. 
Passo CBC. Internação decorrentes do uso de substancias no Distrito Federal entre os anos de 2000 a 2009 [Dissertação]. Recife: Fundação Oswaldo Cruz; 2010.

Perr IN. Pathological intoxication and alcohol idiosyncratic intoxication - Part I: Diagnostic and clinical Aspects. J Forensic Sci. 1986;31(3):806-11.

Pelc I. Alcoholism: relapse preventi. Rev Med Brux. 1997;18(4):272-6.

Petersen EN. The pharmacology and toxicology of disulfiram and its metabolites. Acta Psychiatr Scand Suppl. 1992;369:7-13.

Pettinati HM, Oslin DW, Kampman KM, Dundon WD, Xie H, Gallis TL, Dackis $\mathrm{CA}$, O`Brien CP. A double-blind, placebo-controlled trial combining sertraline and naltrexone for treating co-occurring depression and alcohol dependence. Am J Psychiatry. 2010;167:668-675.

Pettinati HM, Weiss RD, Dundon W, Miller WR, Donovan D, Ernst DB, Rounsaville BJ. A structured approach to medical management: a psychosocial intervention to support pharmacotherapy in treatment of alcohol dependence. J Stud Alcohol Suppl. 2005;15:170-8.

Piche T, Vanbiervliet G, Cherikh F, Antoun Z, Huet PM, Gelsi E, Demarquay JF, Caroli-Bosc FX, Benzaken S, Rigault MC, Renou C, Rampal P, Tran A. Effect of ondansetron, a 5-HT3 receptor antagonist, on fatigue in chronic hepatitis C: a randomised, double blind, placebo controlled study. Gut. 2005;54(8):1169-73.

Pinelli A, Trivulzio S, Tomasoni L. Effects of ondansetron administration on opioid withdrawal syndrome observed in rats. Eur J Pharmacol. 1997;340(23):111-9.

Porro CA. Open your mind to placebo conditioning. Pain. 2009;145(1-2):2-3.

Pritchard JF. Ondansetron metabolism and pharmacokinetics. Semin Oncol. 1992;19(4 Suppl 10):9-15.

Puz CA, Stokes SJ. Alcohol withdrawal syndrome: assessment and treatment with the use of the Clinical Institute Withdrawal Assessment for Alcohol - Revised. Crit Care Nurs Clin North Am. 2005;17(3):297-304.

Quinn DI, Wodak A, Day RO. Pharmacokinetic and pharmacodynamics principles of illicit drug use and treatment of illicit drug users. Clin Pharmacokinet. 1997;33(5):344-400.

Raistrick D, Dunbar G, Davidson R. Development of a questionnaire to measure alcohol dependence. Br J Addiction. 1983;78:89-95.

Rees DW, Beech HR, Hore BD. Some factors associated with compliance in the treatment of alcoholism. Alcohol Alcohol. 1984;19(4):303-07. 
Reynolds T, Cooke F, Murch N. Problem based review: alcohol-use disorders on the Acute Medical Unit. Acute Med. 2012;11(2):101-6.

Reoux JP, Miller K. Routine hospital alcohol detoxification practice compared to symptom triggered management with an Objective Withdrawal Scale (CIWA-AR). Am J Addict. 2000;9(2):135-144.

Ribeiro MS, Ribeiro LC, Souza GF, Antunes; Nogueira RB, Sousa KDC. Aplicabilidade da classificação de alcoolismo tipo A/ tipo B. J Bras Psiquiatr. 2009;58(1):17-25.

Ribeiro MS, Ribeiro LC, Souza GF, Antunes MG, Oliveira LN. Avalição dos Tipos 1 e 2 de alcoolismo de Cloninger em homens participantes de um programam de tratamento ambulatorial. Rev Psiquiatr Clin. 2008;35(2):3548.

Ribeiro MS, Guirro UBP, Baldi BG. Tipologias em alcoolismo: diagnóstico e terapeutica. Arq Bras Psiquiatr Neurol Med Legal. 2002:80/81:24-32.

Robins LN, Helzer JE, Weissman MM, Orvaschel H, Gruenberg E, Burke JD, Regier DL. Lifetime prevalence of specific psychiatric disorders in three sites. Arch Gen Psychiatry. 1984;41(10):949-58.

Roila F, Del-Favero A. Antiemetics revisited. Curr Opin Oncol. 1997;9(4):3216.

Rosenthal NR. Current and future drug therapies for alcohol dependence. J Clin Psychopharmacol. 2009;26(1):20-9.

Rosner S, Hackl-Herrwerth A, Leucht S, Vecchi S, Srisurapanot M, Soyka M. Opioid antagonists for alcohol dependence. Cochrane Database Syst Rev; 2010:(12):CD001867.

Ross S, Peselow E. The Neurobiology of addictive disorders. Clin Neuropharmacol. 2009;32(5):269-76.

Roy-Chengappa KN, Schwarzman LK, Hulihan JF, Xiang J, Rosenthal NR. Adjunctive topiramate therapy in patients receiving a mood stabilizer for bipolar I disorder: a randomized, placebo-controlled trial. J Clin Psychiatry. 2006;67(11):1698-706.

Rubio G, Martinez-Gras I, Manzanares J. Modulation of impulsivity by topiramate: implications for the treatment of alcohol dependence. J Clin Psychopharmacol. 2009;29(6):584-9.

Rubio G, Ponce G, Rodrigues-Jimenez R, Jimenez-Arriero MA, Hoenicka J, Palomo T. Clinical predictors of response to naltrexone in alcoholic patients: who benefits most from treatment with naltrexone? Alcohol Alcohol. 2005;40(3):227-33. 
Saunders JB, Paton A. ABC of Alcohol. Br Med J. 1981;283(6303):1380-1.

Schaffer A, Naranjo CA. Recommended drug treatment strategies for the alcoholic patient. Drugs. 1998;56(4):571-85.

Schmidt LG, Smolka MN. Results from two pharmacotherapy trials show alcoholic smokers were more severely alcohol dependent but less prone to relapse than alcoholic non-smokers. Alcohol Alcohol. 2007;42(3):241-6.

Scott LJ, Figgitt DP. Keam SJ, Waugh J. Acamprosate: a review of its use in the maintenance of abstinence in patients with alcohol dependence. CNS Drugs. 2005;19(5):445-64.

Sell LA, Cowen PJ, Robson PJ. Ondansetron and opiate craving. A novel pharmacological approach to addiction. Br J Psychiatry. 1995;166(4):511-4.

Sellers EM, Toneatto T, Romach MK Somer GR, Sobell LC, Sobell MB. Clinical efficacy of the 5-HT3 antagonist ondansetron in alcohol abuse and dependence. Alcohol Clin Exp Res. 1994;18(4):879-85.

Sharpe PC, Mcbride R, Archbold GP. Biochemical markers of alcohol abuse. QJM. 1996;89(2):137-44.

Shaw JM, Kolesar GS, Sellers EM, Kaplan H. Development of optimal treatment tactics for alcohol withdrawal. I Assessment and effectiveness of supportive care. J Clin Psychopharmacol. 1981;1(6):382-8.

Sigvardsson S, Bohman M, Cloninger CR. Replication of the Stockholm Adoption Study of alcoholism: Confirmatory cross-fostering analysis. Arch Gen Psychiatry. 1996;53:681-7.

Silveira CM, Silveira CC, Da Silva JG, Silveira LM, Andrade AG, Andrade LHSG. Epidemiologia do beber pesado e beber pesado episódico no Brasil: uma revisão sistemática da literatura. Rev Psiq Clín. 2008;35(1):31-8.

Simpson DD, Joe GW, Brown BS. Treatment retention and follow-up outcomes in the drug abuse treatment outcome study (DATOS). Psychol Addict Behav. 1997;11:294-307.

Simpson $\mathrm{KH}$, Hicks FM. Clinical pharmacokinetics of ondansetron. A review. J Pharm Pharmacol. 1996;48(8):774-81.

Simpson $\mathrm{KH}$, Murphy $\mathrm{P}$, Colthup $\mathrm{PV}$, Whelan $\mathrm{P}$. Concentration of ondansetron in cerebrospinal fluid following oral dosing in volunteers. Psychopharmacology (Berl). 1992;109(4):497-8.

Sirota P, Mosheva T, Shabtay H, Giladi N, Korczyn AD. Use of the selective serotonin 3 receptor antagonist ondansetron in the treatment of neurolepticinduced tardive dyskinesia. Am J Psychiatry. 2000;157(2):287-9.

Smith JC Barnes EL Jr, Fukui MB, Myers EN. Pathology forum: quiz case 2. Diagnosis: hibernoma. Arch Otolaryngol Head Neck Surg. 2000;126(9):1154. 
Soltani F, Sayyah M, Feizy F, Malayeri A, Siahpoosh A, Motlagh I. A doubleblind, placebo-controlled pilot study of ondansetron for patients with obsessive-compulsive disorder. Hum Psychopharmacol. 2010;25(6):509-13.

Soyka M, Schmidt P. Outpatient alcoholism treatment 24 month outcome and predictors of outcome. Subst Abuse Treat Prev Policy. 2009; 4:15.

Srisurapanot M, Jarusuraisin N. Naltrexone for the treatment of alcoholism: a meta-analysis of randomized controlled trials. Int $\mathrm{J}$ Neuropsychopharmacol. 2005;8(2):267-80.

Stahl SM. Psicofarmacologia: Bases Neurocientíficas e Aplicação Práticas. 3a ed. Rio de Janeiro: Guanabara Koogan; 2010.

Stark MJ. Dropping out of substance abuse treatment: A clinically oriented review. Clin Psychol Rev. 1992;12:93-116.

Stasiewick PR, Stalker R. A comparasion of three interventions on pretreatment dropout rates in na outpatient substance abuse clinic. Addict Behav. 1999;24(2):579-82.

Sullivan JT, Sykora K, Schneiderman J, Naranjo CA, Sellers EM. Assessment of Alcohol Withdrawal: the revised clinical institute withdrawal assessment for alcohol scale (CIWA-Ar). Br J Addict.1989; 84(11):1353-7.

Sun L, Konig IR, Jacobs A, Seitz HK, Junghanns K, Wagner T, Ludwing D, Jacrobs A, Homann N. Mean corpuscular volume and ADH1C genotype in white patients with alcohol-associated diseases. Alcohol Cin Exp Res. 2005;29(5):788-93.

Swift RM, Davidson D, Whelihan W, Kuznetsov O. Ondansetron alters human alcohol intoxication. Biol Psychiatry. 1996;40(6):514-21.

Thom B, Brown C, Drummond C, Edwards G, Mullan M, Taylor C. Engaging patients with alcohol problems in treatment: The first consultation. $\mathrm{Br} J$ Addict. 1992;87(4):601-11.

Tonigan JS, Toscova R, Miller WR. Meta-analysis of the literature on Alcoholics Anonymous: sample and study characteristics moderate findings. J Stud Alcohol. 1996;57(1):65-72.

Toren P, Laor N, Cohen DJ, Wolmer L, Weizman A. Ondansetron treatment in patients with Tourette's syndrome. Int Clin Psychopharmacol. 1999;14(6):373-6.

Thomas $\mathrm{SE}_{2}$ Randall $\mathrm{CL}_{2}$ Carrigan $\mathrm{MH}$. Drinking to cope in socially anxious individuals: a controlled study. Alcohol Clin Exp Res. 2003;27(12):1937-43.

Vale C, Oliveira F, Assunção J, Fontes-Ribeiro C, Pereira F. Coadministration of ondansetron decreases the analgesic efficacy of tramadol in humans. Pharmacology. 2011;88(3-4):182-7. 
Van-Sassenbroaeck DK, De-Paepe $P$, Belpaire FM, Buylaert WA. Characterization of the Pharmacokinetic and Pharmacodynamic Interaction between Gamma-Hydroxybutyrate and Ethanol in the Rat. Toxicol Sci. 2003;73(2):270-8.

Van-Thiel DH, Gavaler JS. Ethanol metabolism and hepatotoxicity. Does sex make difference? Recent Dev Alcohol. 1988;6:291-304.

Vasconcelos SMM, Feitosa LB, Felix PA, Aguiar LMV, De-Souza FCF, Viana GSB. Motivação, vias neuronais e drogas de abuso. Rev Psiq Clín. 2002;29(3):130-4.

Vein A. "Sergey Sergeevich Korsakov (1854-1900)". J Neurol. 2009;256(10):1782-83.

Viala-Artigues J, Mechetti C. Histoire de l'alcool archéologie parti 1. 2003. Paris: Fédération des Acteurs de I'Alcohologie et de l'Addictologie. [citado 2012 out 01]. Disponivel em:http://www.alcoologie.org/Histoire-de-l-alcoolarcheologie.

Volpicelli JR, Teitelbaum SA. Ambulatory alcohol Detoxification. Uptodate; 2012. [citado 2012 out 10]. Disponível em: http://www.uptodate.com/contents/ambulatory-alcohol-detoxification.

West R, Hajek P. Randomised controlled trial of ondansetron in smoking cessation. Psychopharmacology (Berl). 1996;126(1):95-6.

World Health Organization. Alcohol in the European Union consumption, harm and policy approaches. Copenhagen - Denmark: World Health Organization; 2011a. .[citado 2012 ago 27] Disponivel em: http://www.euro.who.int/_data/assets/pdf_file/0003/160680/e96457.pdf.

World Health Organization. Global status report on alcohol and health. Geneva: World Health Organization; 2011b. .[citado 2012 ago 27] Disponível em:

http://www.who.int/substance_abuse/publications/global_alcohol_report/sbgs ruprofiles.pdf.

World Health Organization. Total adult per capita consumption of pure alcohol (in litres), 2005. Geneva: World Health Organization; 2005. .[citado 2012 abr 10]. Disponivel em:http://www.who.int/substance_abuse/publications/global_alcohol_report/ msbgsruprofiles.pdf.

World Health Organization. The World health report 2002: reducing risks, promoting healthy life. Geneva: World Health Organization; 2002. .[citado 2012 abr 10] Disponível em: http://www.who.int/whr/ 2002/download/en/

World Health Organization. International guide for monitoring alcohol consumption and related harm. Geneva: World Health Organization; 2000. 
World Health Organization. Lexicon of alcohol and drug terms publish by the World Health Organization, 1994.[citado 2012 abr 14]. Disponível em: http://www.who.int/substance__ abuse who_lexicon/en/index.html /terminology/

Wilde MI, Wagstaff AJ. Acamprosate. A review of its pharmacology and clinical potential in the management of alcohol dependence after detoxification. Drugs. 1997;53(6):1038-53.

Ye JH, Ponnudurai R, Schaefer R. Ondansetron: a selective 5-HT(3) receptor antagonist and its applications in CNS-related disorders. CNS Drug Rev. $2001 ; 7(2): 199-213$.

Zago-Gomes MP, Nakamura-Palacios EM. Tipologia de Lesch em alcoolistas no Brasil. J Bras Psiquiatr. 2009;58(3):169-74.

Zaleski M, Laranjeira R, Marques AC, Ratto L, Romano M, Alves HN, Soares MB, Abelardino V, Kessler F, Brasiliano S, Nicastri S, Hochgraf PB, Gigliotti Ade P, Lemos T; Brazilian Association of Studies on Alcohol and Other Drugs. [Guidelines of the Brazilian Association of Studies on Alcohol and Other Drugs (ABEAD) for diagnoses and treatment of psychiatric comorbidity with alcohol and other drugs dependence]. Rev Bras Psiquiatr. 2006 Jun;28(2):142-8.

Zancy JP, Apfelbaum JL, Lichtor JL, Zaragoza JG. Effects of 5hydroxytryptamine 3 antagonist, ondansetron, on cigarette smoking, smoke exposure, and mood in humans. Pharmacol Biochem Behav. 1993;44(2):387-91.

Zhang Y, Guo X, Saitz R, Levy D, Sartini E, Niu J, Ellison RC. Secular trends in alcohol consumption over 50 years: the Framingham study. Am J Med. 2008;121(8):695-701.

Zhang ZJ, Kang WH, Li Q, Wang XY, Yao SM, Ma AG, Beneficial effects of ondansetron as an adjunct to haloperidol for chronic, treatment-resistant schizophrenia: a double-blind, randomized, placebo-controlled study. Schizophr Res. 2006;88(1-3):102-10.

Zhou Q, Lovinger DM. Pharmacologic characteristics of potentiation of 5-HT3 receptors by alcohols and diethyl ether in NCB-20 neuroblastoma cells. J Pharmacol Exp Ther. 1996 278(2):732-40.

Zoldan J, Friedberg G, Livneh M, Melamed E. Psychosis in advanced Parkinson's disease: treatment with ondansetron, a 5-HT3 receptor antagonist. Neurology. 1995;45(7):1305-8.

Zubaran C, Fernandes J, Martins F, Souza J, Machado R, Cadore M. Aspectos clínicos e neuropatológicos da síndrome de Wernicke-Korsakoff. Rev Saúde Pública. 1996;30(6):602-8. 